UNIVERSIDADE DE SÃO PAULO

INSTITUTO DE GEOCIÊNCIAS

\title{
SEDIMENTOLOGIA, CRONOLOGIA E DINÂMICA PROGRADACIONAL DAS PLANÍCIES COSTEIRAS DE CAMPOS VERDES E JI (LAGUNA, SC)
}

Ana Paula Burgoa Tanaka

Orientador: Prof. Dr. Paulo César Fonseca Giannini

DISSERTAÇÃO DE MESTRADO

Programa de Pós-Graduação em Geoquímica e Geotectônica

SÃO PAULO

2010 
"Aí está ele, o mar, a mais ininteligível das existências não humanas. E aqui está a mulher, de pé na praia, o mais ininteligível dos seres vivos. Como ser humano fez um dia uma pergunta sobre si mesmo, tornou-se o mais ininteligível dos seres vivos. Ela e o mar.

Só poderia haver um encontro de seus mistérios se um se entregasse ao outro: a entrega de dois mundos incognoscíveis feita com a confiança com que se entregariam duas compreensões.

Mesmo que o esqueça daqui a uns minutos, nunca poderá perder tudo isso."

As águas do mundo - Clarice Lispector 


\section{AGRADECIMENTOS}

Aos meus pais Antonio e Maritza, por sempre valorizarem e respeitarem minhas escolhas; muito obrigada, pai e mãe, pelo apoio e compreensão! À minha querida irmã, que apesar de morar do outro lado do oceano, está sempre presente.

Ao amigo e orientador Prof. Paulo C. F. Giannini, que me mostrou caminhos, me ensinou a engatinhar e depois a andar neles e através deles. Ao também amigo e co-orientador Prof. André $\mathrm{O}$. Sawakuchi, que me deu empurrões necessários para o desenvolvimento deste trabalho.

Aos companheiros de pesquisa, André Zular, Carlos Guedes (Sfincter), Daniel Nascimento Jr. (Peg), Milene Fornari, Paula Amaral (Pi), Priscila Menezes (Xiw), Selma Rodrigues, Vinicius Ribau e Ximena Villagran pelas dicas, conversas e ajudas. Aos colegas de pós-graduação, Jorge (Bizzaro), André (Kodorna), Roberta (Pisa), Thais (Tchitcho), Emiliano (Kiwi), Brenda (Kupeludo), Nicolas (Pânico), Felipe (Banheirão), Felipe (Orso), Paula Sucerquia, Gabriella, Thiago (Trena), Maurício (Borboleta), Diana Valadares e Felix (GG).

Ao Hilton G. Fernandes, por conceber o modelo em Python e pelos esclarecimentos sobre essa linguagem, e ao Prof. Carlos H. Grohmann, pelo Aprendendo Python.

Agradeço à Profa. Regina DeWitt, que realizou as datações LOE no Radiation Dosimetry Laboratory, Oklahoma St. University. Ao pessoal do LabSed e LabPetro: Vitor, Elaine, Isaac e Tainá muito obrigada pelo auxílio. A todos os funcionários do Instituto de Geociências da USP.

Ao Prof. Francisco W. da Cruz Jr., pelas sugestões e explicações sobre paleoclima.

Aos novos amigos da geofísica, Ângelo, Ana Elisa, Baiano, Caio, Frederico e Karine, pelo bom humor e companheirismo. Aos irmãos $\mathrm{Na}$, Rafa e Vi Gitti que fizeram parte da família $101 \mathrm{C}$ durante esses dois anos. Às amigas geólogas Talita (Xoca), Daina, Ana e Grace, o Rio de Janeiro continua lindo! À amiga física Pat Magalhães pelas dicas de Origin e conversas de bandejão. Ao Marcel por me ajudar com o sprint final nas impressões. E aos amigos "humanos" Dea Morganti, Felipe Moreira e Natália Gitti, eu se divirto com vocês.

Obrigada ao meu time (BAFEFI), que me recebe de braços abertos toda quarta-feira para jogar basquete; essa descontração foi fundamental durante o mestrado.

Aos alunos da oceanografia que cursaram a disciplina princípios da geologia sedimentar em 2009 e aos alunos da geologia que estão cursando a disciplina sedimentologia, por me ajudarem a enxergar a geologia sedimentar sob outra perspectiva e por cativar a minha vontade de aprender e compartilhar.

Aos alunos e professores da disciplina simulação dos sistemas complexos.

À Fundação de Amparo à Pesquisa do Estado de São Paulo (FAPESP), pelo apoio financeiro concedido através de Projeto Temático (04/11038-0), Auxílio à Pesquisa (05/520346) e Bolsa de Mestrado (08/50767-8). 


\section{SUMÁRIO}

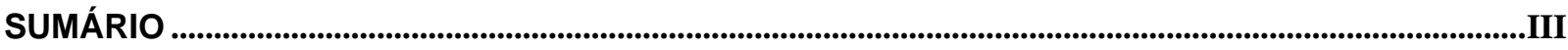

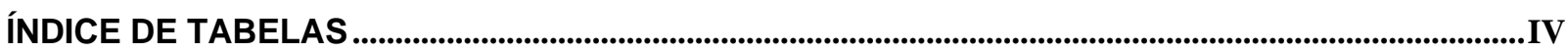

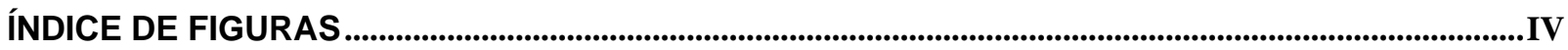

ABSTRACT

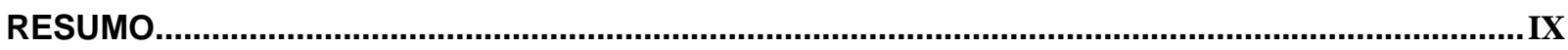

1. INTRODUÇÃO

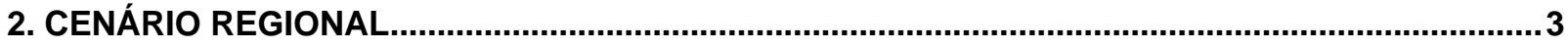

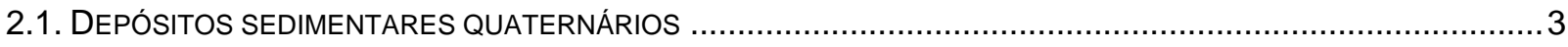

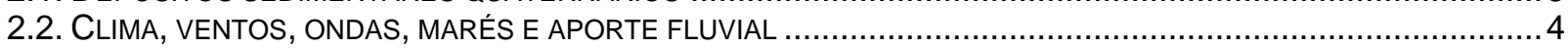

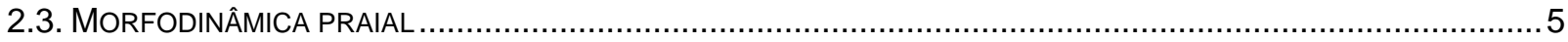

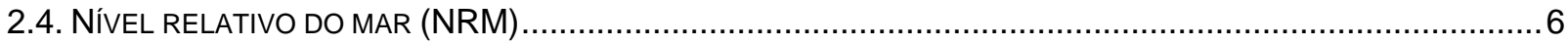

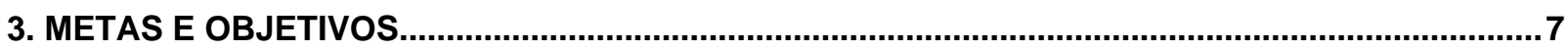

4. FUNDAMENTAÇÃO TEÓRICA

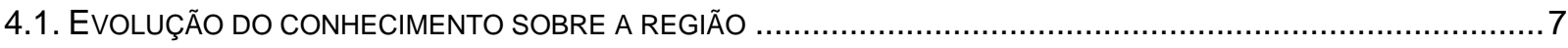

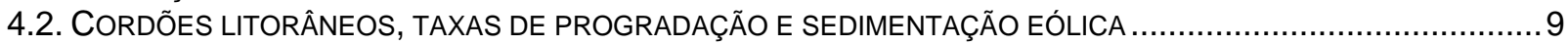

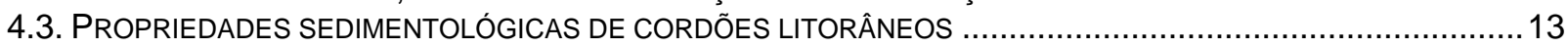

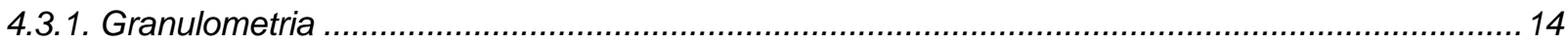

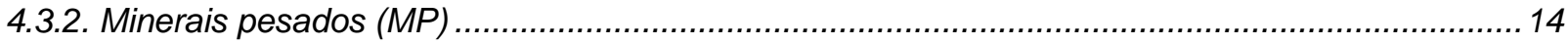

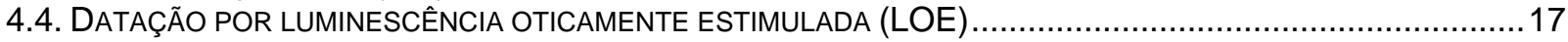

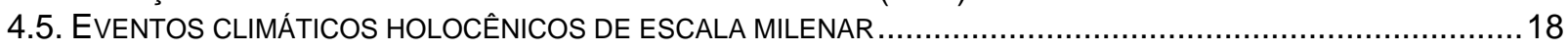

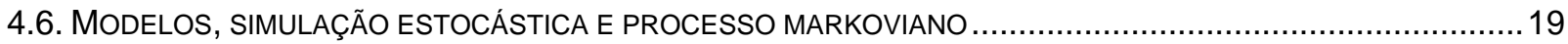

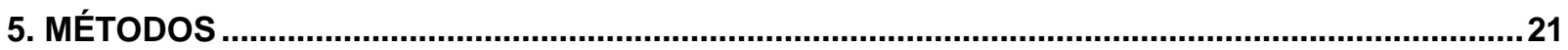

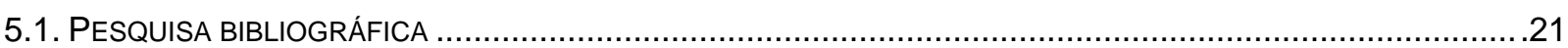

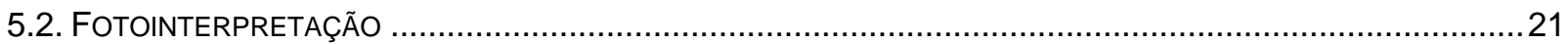

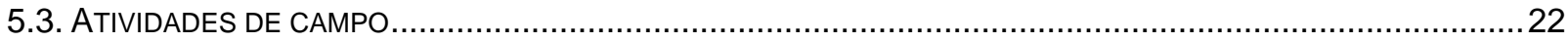

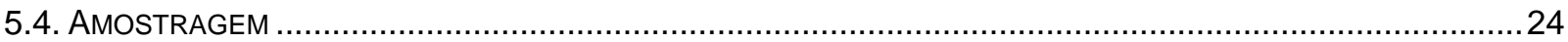

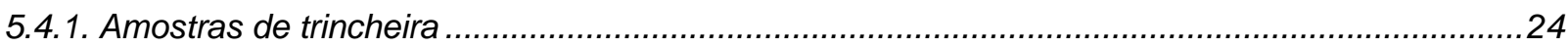

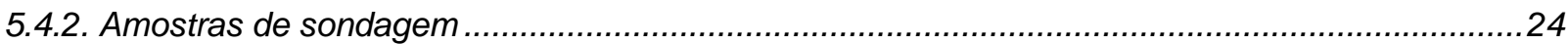

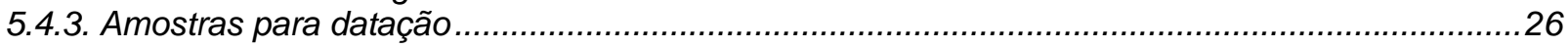

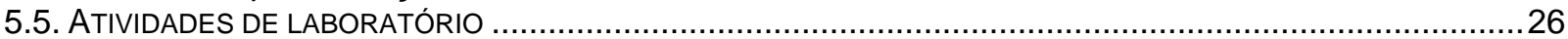

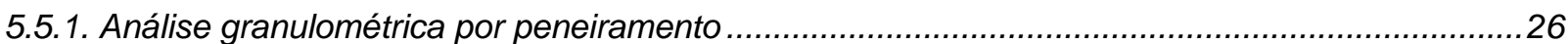

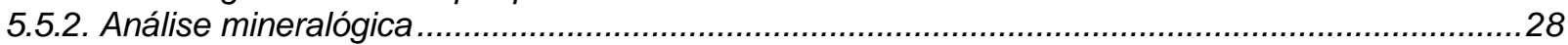

5.5.3. Datação

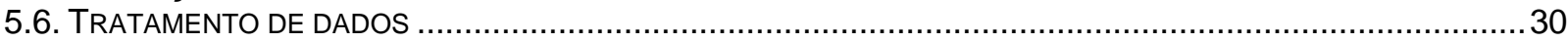

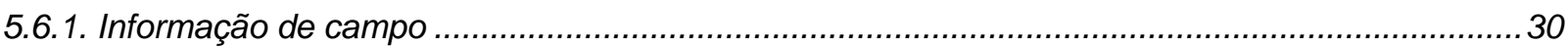

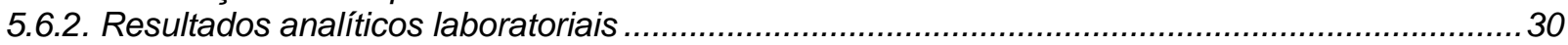

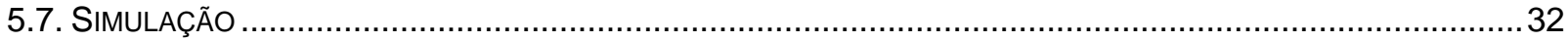

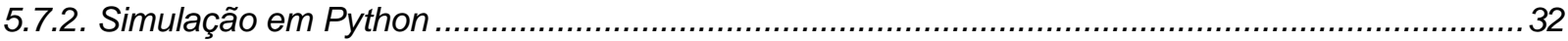

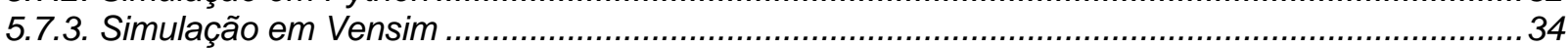

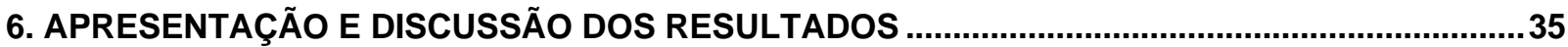

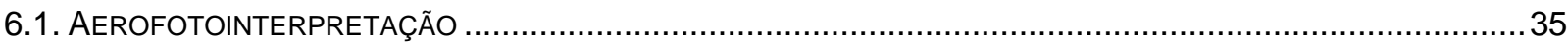

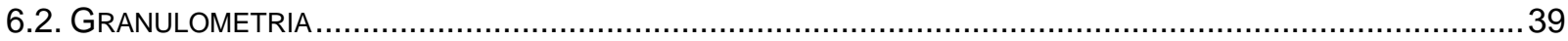

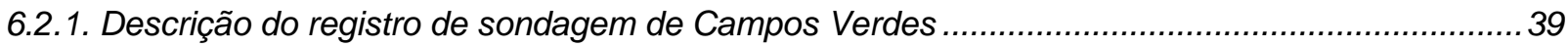

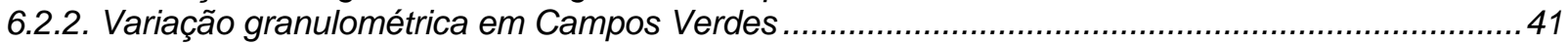

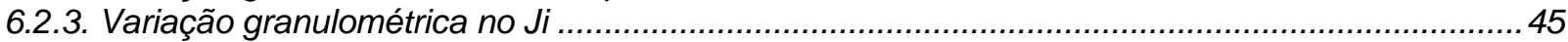

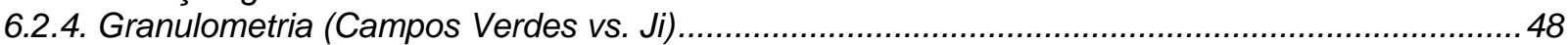

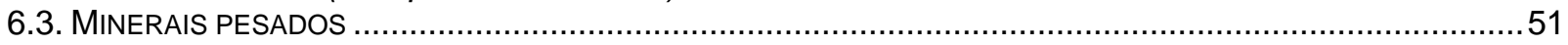

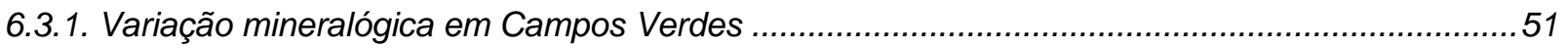

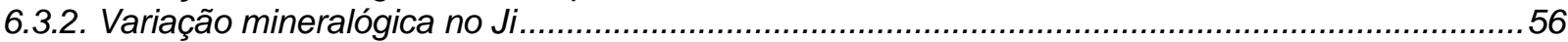

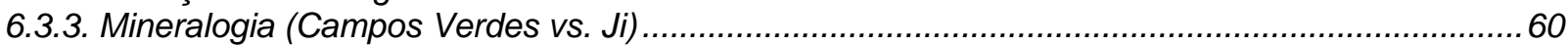

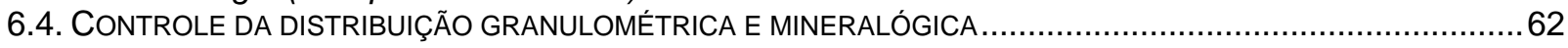




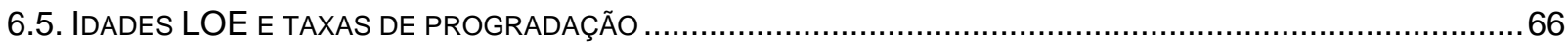

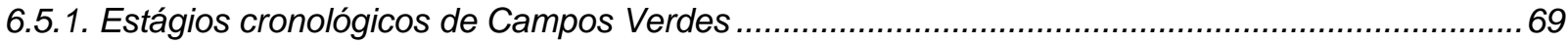

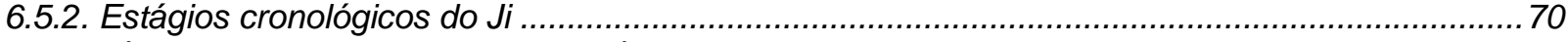

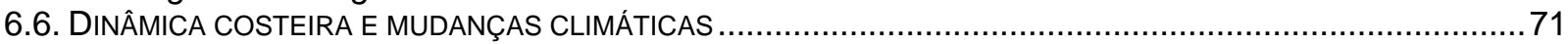

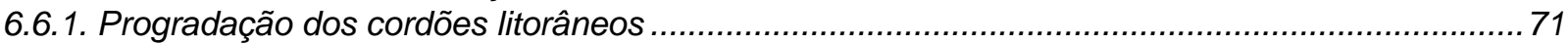

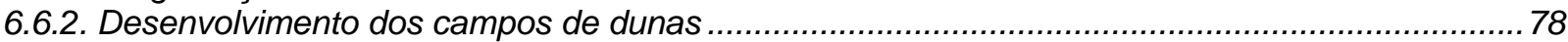

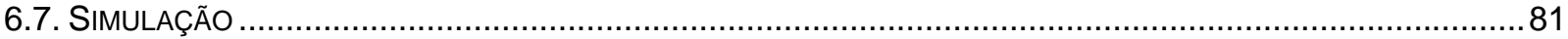

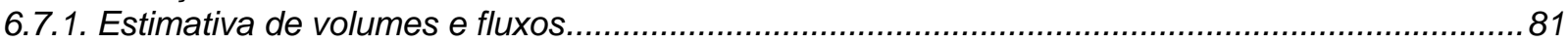

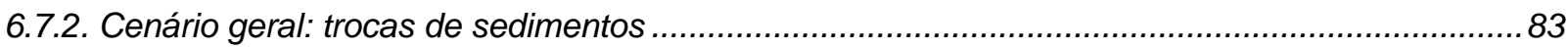

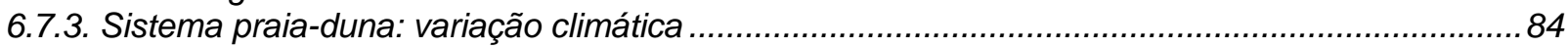

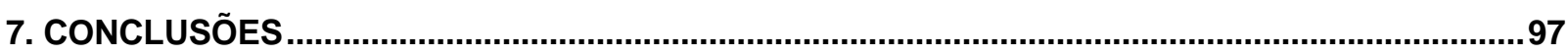

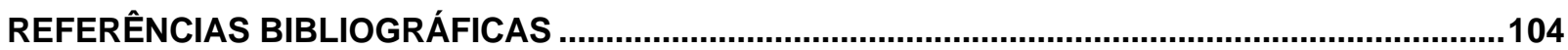

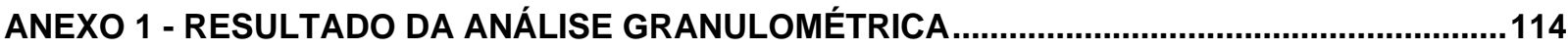

ANEXO 2 - RESULTADO DA CONTAGEM DE MINERAIS PESADOS

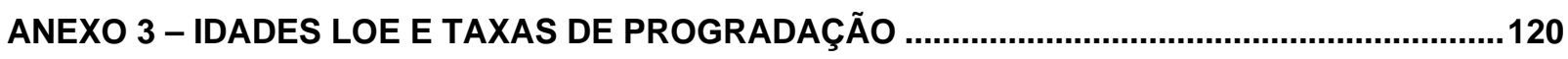

ANEXO 4 - ESTRUTURA DO PROGRAMA PARA SIMULAÇÃO DO CENÁRIO GERAL .................121

ANEXO 5 - ESTRUTURA DO PROGRAMA PARA SIMULAÇÃO DO SISTEMA PRAIA-DUNA .......133 


\section{ÍNDICE DE TABELAS}

Tabela 4.1 - Taxas de progradação de planícies de cordões litorâneos no mundo................................13

Tabela 5.1 - Dado da sondagem STO executada na planície de Campos Verdes...............................25

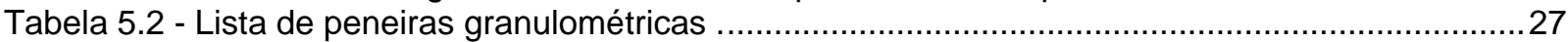

Tabela 6.1 - Freqüências percentuais médias dos minerais pesados de Campos Verdes ....................51

Tabela 6.2 - Freqüências percentuais médias dos minerais pesados do Ji......................................57

Tabela 6.3 - Matriz de correlação entre variáveis granulométricas e mineralógicas...............................62

Tabela 6.4 - Valores obtidos na análise de componentes principais .................................................64

Tabela 6.5 - Concentração de tório, urânio e potássio, taxas de doses e idades LOE .........................67

Tabela 6.6 - Estágios de evolução, séries correspondentes, distância a partir do mar, intervalo de

tempo envolvido e taxas de progradação mínimas e médias...................................................................69

Tabela 6.7 - Matriz de probabilidades para trocas de sedimentos o cenário geral. ................................83

Tabela 6.8 - Parâmetros iniciais (input) para simulação do cenário geral...............................................83

Tabela 6.9 - Comparação entre os valores reais e os valores obtidos em simulação. ...........................84

Tabela 6.10 - Parâmetros climáticos utilizados para simular cenário de clima úmido. ...........................89

Tabela 6.11 - Parâmetros inicias de estoque e fluxo para o cenário 1 do sistema praia-duna..............89

Tabela 6.12 - Parâmetros climáticos utilizados para simular cenário de clima seco. .............................92

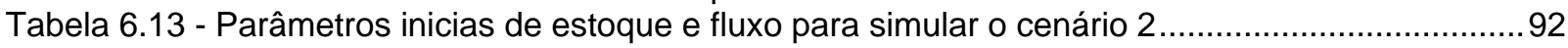

Tabela 6.14 - Parâmetros climáticos utilizados para simular cenário de clima ameno...........................95

Tabela 6.15 - Parâmetros inicias de estoque e fluxo para simular o cenário 3.....................................95

\section{ÍNDICE DE FIGURAS}

Figura 2.1 - Localização das áreas de estudo em relação aos sistemas deposicionais ............................. 3

Figura 2.2 - Curva de nível relativo do mar (NRM) do Holoceno médio................................................

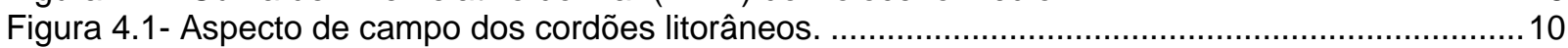

Figura 4.2 - Aspecto de campo das dunas eólicas....................................................................... 12

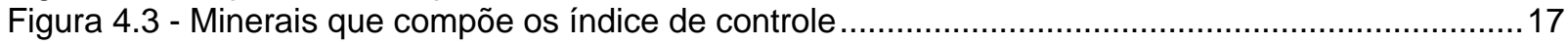

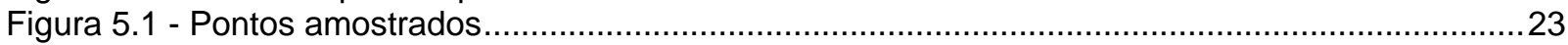

Figura 5.2 - Equipamento de sondagem a trado oco (STO) e coleta de amostras...................................2.

Figura 5.3 - Representação dos fluxos (setas) entre compartimentos (caixas). ....................................33

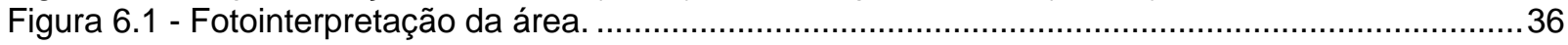

Figura 6.2 - Feixes de alinhamentos de cordões de Campos Verdes................................................37

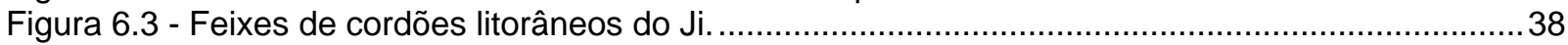

Figura 6.4 - Aspecto da amostras do furo de sondagem e distribuição de freqüências dos intervalos

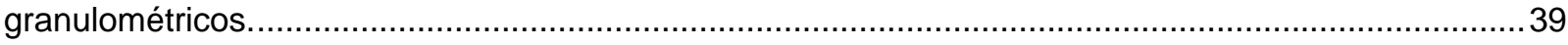

Figura 6.5 - Posição esquemática das amostras de trincheira e do furo de sondagem em relação à

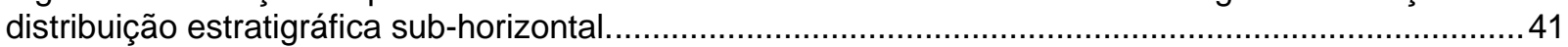

Figura 6.6 - Seção que representa a estratigrafia e sedimentologia tipo das amostras de cordões

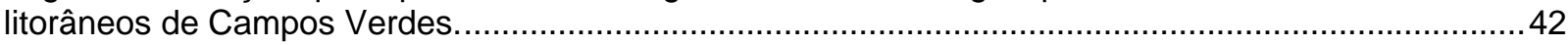

Figura 6.7 - Variação dos parâmetros estatísticos da distribuição granulométrica de Campos Verdes.43

Figura 6.8 - Vetores de transporte e/ou retrabalhamento sedimentar para Campos Verdes. ................44

Figura 6.9 - Variação dos parâmetros estatísticos da distribuição granulométrica da fração areia para

amostras do furo de sondagem realizado em Campos Verdes...........................................................45

Figura 6.10 - Seção que representa a estratigrafia e sedimentologia tipo das amostras de cordões

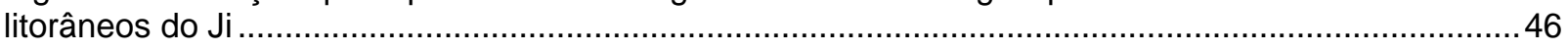

Figura 6.11 - Variação dos parâmetros estatísticos da distribuição granulométrica do Ji. .....................47

Figura 6.12 - Vetores de transporte e/ou retrabalhamento sedimentar para o Ji..................................48

Figura 6.13 - Boxplots dos parâmetros granulométricos para amostras de cordão e duna de Campos

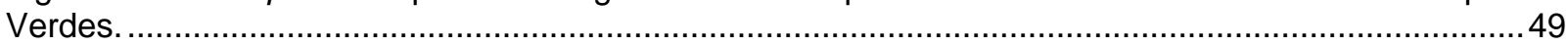

Figura 6.14 - Boxplots das variáveis granulométricas para cada categoria faciológica de amostras das

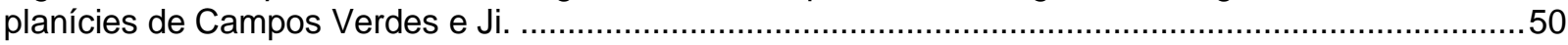

Figura 6.15 - Matriz de dispersão das variáveis granulométricas para cada categoria faciológica de amostras das planícies de Campos Verdes e Ji...........................................................................50

Figura 6.16 - Aspectos típicos de alguns minerais pesados dos sedimentos de Campos Verdes.......52

Figura 6.17 - Índices de minerais pesados da fração areia muito fina.................................................54

Figura 6.18 - Variação espacial de índices de minerais pesados de Campos Verdes ...........................55

Figura 6.19 - Variação dos índices de minerais pesados do furo de sondagem.....................................56 


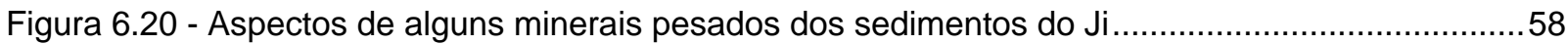

Figura 6.21 - Variação dos índices de minerais pesados do Ji. .......................................................59

Figura 6.22 - Variação espacial de índices de minerais pesados do Ji..............................................60

Figura 6.23 - Boxplots dos índices de minerais pesados, para amostras de dunas e cordões ..............61

Figura 6.24 - Matriz de correlação entre os índices de minerais pesados (iHT, iTZ e clrINS) ................62

Figura 6.25 - Diagrama de dispersão em matriz (matrixplot) de DM, DP e clrZTR .................................63

Figura 6.26 - Gráficos de regressão linear. A) Entre iHT e clrINS. B) Entre Idade e clrZTR. .................64

Figura 6.27 - Gráfico da PC1 pela PC2 para amostras de cordões e dunas. .......................................65

Figura 6.28 - Gráficos da PC1 pela PC2 com scores categorizados por local.....................................66

Figura 6.29 - Perfil esquemático de idades LOE ao longo da planície de Campos Verdes......................66

Figura 6.30 - Perfil esquemático de idades LOE ao longo da planície do Ji .........................................67

Figura 6.31 - Localização das amostras datadas, e respectivas idades em anos AP ...........................68

Figura 6.32 - Variação das taxas de progradação ao longo do tempo................................................ 72

Figura 6.33 - Variação dos indices de controle (iHT, iTZ e iRZ) ao longo do tempo...............................74

Figura 6.34 - Gráfico de variação isotópica ao longo do tempo, registrada em estalagmite da caverna

Botuverá, em Santa Catarina e sua relação com os períodos de diminuição de salinidade ..................76

Figura 6.35 - Gráfico de variação isotópica ao longo do tempo de conchas de Anomalocardia brasiliana

coletas no grande sistema de lagunas da área estudada. ............................................................ 78

Figura 6.36 - llustração esquemática da praia e do campo de dunas comparados a formas geométricas

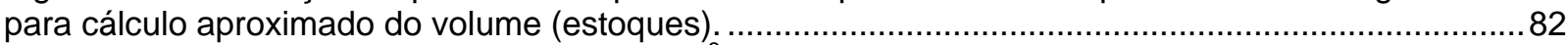

Figura 6.37 - Gráfico de volume acumulado $\left(\mathrm{m}^{3}\right)$ ao longo do tempo (anos). Resultado da simulação do

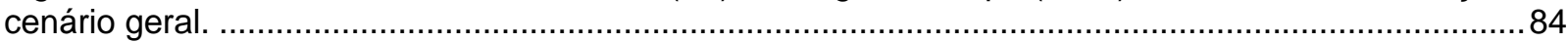

Figura 6.38 - Estrutura do modelo para simulação do sistema praia-duna.......................................... 85

Figura 6.39 - Detalhe da estrutura do modelo, gerador de chuvas. ................................................ 86

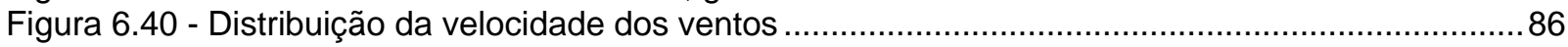

Figura 6.41 - Média da distribuição da precipitação observada por trimestre para a estação de Torres

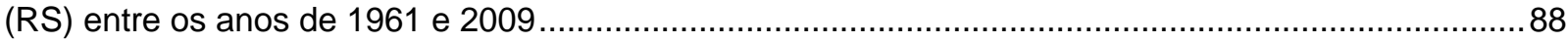

Figura 6.42 - Dstribuição das amplitudes de maré ao longo do ano de 2008 ..................................... 89

Figura 6.43 - Gráficos de distribuição das variáveis climáticas do cenário 1 . ......................................90

Figura 6.44 - Gráfico de acumulo de sedimentos do cenário 1 para clima úmido. ................................90

Figura 6.45 - Gráfico de acumulo de sedimentos do cenário 1 para clima ameno ................................91

Figura 6.46 - Gráfico de acumulo de sedimentos do cenário 1 para clima seco...................................92

Figura 6.47 - Gráficos de distribuição das variáveis climáticas do cenário 2 ......................................93

Figura 6.48 - Gráfico de acumulo de de sedimentos do cenário 2 para clima seco...............................93

Figura 6.49 - Gráfico de acumulo de de sedimentos do cenário 2 para clima ameno ............................94

Figura 6.50 - Gráfico de acumulo de sedimentos do cenário 2 para clima úmido. ...............................94

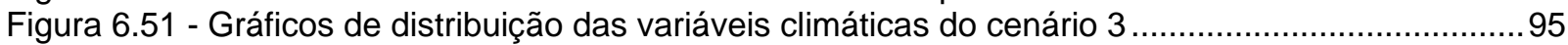

Figura 6.52 - Gráfico de acumulo de sedimentos do cenário 3 para clima ameno ...............................96

Figura 6.53 - Gráfico de acumulo de sedimentos do cenário 3 para clima úmido ................................96

Figura 6.54 - Gráfico de acumulo de sedimentos do cenário 3 para clima seco...................................97

Figura 7.1 - llustração em etapas do modelo de evolução sedimentar da planície de Campos Verdes

com posterior reativação das dunas.......................................................................................... 101

Figura 7.2 - Ilustração em etapas do modelo de evolução sedimentar da planície de Campos Verdes

com desenvolvimento das dunas durante a Pequena Idade do Gelo.................................................102

Figura 7.3 - Ilustração em etapas do modelo de evolução sedimentar da planície do Ji......................103 


\section{Sedimentology, chronology and progradational dynamics of the coastal plains of Campos Verdes and Ji (Laguna, state of Santa Catarina, southern Brazil)}

\section{ABSTRACT}

The Holocene strandplains of Campos Verdes and Ji (south coast of Santa Catarina, southern Brazil) are characterized by truncated sets of beach ridges alternated with eolian dune fields. They represent examples of neighbor coastal plains formed under the same regional context, but under different hydrodynamic contexts: in a sheltered back-barrier embayment (Campos Verdes) and in an open sea tombolo (Ji). The aim of this work is to construct evolutionary models of sedimentation for both plains based in photointerpretation, grain-size, heavy minerals, OSL ages, calculation of progradation rates and computer simulation. The comparative analysis allows the explanation of the origin of processes responsible for the development of the plains defining whether the mechanisms are autocyclic or alocyclic.

Both plains would have begun during the deceleration of the RSL rise, just before the achievement of the Holocene highstand, approximately at 5 ky BP. Patterns of transport and sedimentary reworking based on statistics of grain-size distribution (mean grain-size, standard deviation and skewness) combined with variation of heavy minerals indices (INSi, METi, ZTRi, $\mathrm{TZi}, \mathrm{HTi}, \mathrm{RZi}$ ) show northwards progradation with a longitudinal growth component towards west for Campos Verde and progradation towards east with an alongshore growth component towards north for $\mathrm{Ji}$. The heavy mineral distribution is mainly linked to the shift and approximation of the main fluvial source area (Tubarão delta) with an input of less mature sediments into the system.

The evolution of Campos Verdes was divided into five chronologic stages: before $4912 \pm 270 \mathrm{yr}(1)$; from $4199 \pm 347$ to $2763 \pm 205$ anos (2); from $2763 \pm 205$ to $2816 \pm 193$ anos (3); from $2816 \pm 193$ to $1946 \pm 141$ anos (4); and from $1946 \pm 141$ anos until present (5); with progradation rates of $1.07,0.35,3.45,0.76 \mathrm{~m} / \mathrm{yr}$ and undetermined, respectively. A phase of dune stabilization happened during stage 4 , indicated by a depositional lobe dated in $2255 \pm 123 y$ r and another phase of dune reactivation occurred during stage 5 , indicated by a starved parabolic dune dated in $711 \pm 64 \mathrm{yr}$. Five chronologic stages were defined for Ji: before $2794 \pm 151 \mathrm{yr}(1)$; from $2794 \pm 151$ to $2537 \pm 140 \mathrm{yr}$ (2); from $2537 \pm 140$ to $1031 \pm 35$ (3); from $1031 \pm 35$ to $831 \pm 43 \mathrm{yr}(4)$; and from $751 \pm 43 \mathrm{yr}$ until present (5). The progradation rates determined for the last four stages are 2.26, 0.28, 1.47 and $1.24 \mathrm{~m} / \mathrm{yr}$. A phase of stabilization of eolian generation 3 was dated in $1346 \pm 73 y r$, within the stage 3 . Eolian trangressive dune fields, that are still active, began its development during stage 5. The progradation rates (growth) of the plains show an anti-phase pattern linked to the alternation between two situations: one where there is predominance of net longshore drift towards NE, with frequent cold front incursions and more intense action of polar air mass; and another with the predominance of net 
longshore drift towards SW with more active tropical Atlantic air mass and less frequent cold front incursions. There was a progradational "boom" ca. $2700 \mathrm{yr}$ with higher progradation rates in both plains, which might be linked to the occurrence of a millennial Holocene climate change, the Bond event 2, responsible for the punctual humidity and precipitation increase. Dune development or reactivation during stage 5 in Campos Verdes might be linked to an occurrence of another millennial Holocene climate event, the Little Ice Age.

Eolian fluxes with magnitude of $10^{4} \mathrm{~m}^{3} / \mathrm{yr}$ were obtained using stochastic simulation of a general scenario of sediment exchange between stocks (eg. beach and dune field) for Ji. In simulation conditioned by climatic variables, it is possible to observe that the development of dune fields can occur during rainy periods (mean precipitation above $400 \mathrm{~m}$ ) as long as the eolian fluxes are ten times greater than that ones obtained in the general scenario.

Keywords: beach ridges, eolian dunes, progradation rates, grain-size, heavy minerals 


\section{Sedimentologia, Cronologia e Dinâmica Progradacional das Planícies Costeiras de Campos Verdes e Ji (Laguna, SC)}

\section{RESUMO}

Localizadas no litoral sul de Santa Catarina, as planícies costeiras holocênicas de Campos Verdes e Ji caracterizam-se por séries truncadas de cordões litorâneos alternados a campos de dunas livres. Constituem exemplo de planícies formadas em um mesmo contexto regional, porém sob condições distintas quanto ao caráter hidrodinâmico: área semiprotegida de retrobarreira (Campos Verdes) versus tômbolo de mar aberto (Ji). A meta deste trabalho é construir modelos de evolução sedimentar para estas duas planícies com base em fotointerpretação, granulometria, minerais pesados, idades LOE, cálculo de taxas de progradação e simulação computacional. A comparação visa contribuir para a compreensão dos processos formadores ou remodeladores de planícies de cordões em geral e definir o caráter, se autocíclico ou alocíclico, de cada mecanismo no caso em estudo.

O desenvolvimento destas planícies teria começado durante a desaceleração da subida de NRM, pouco antes do nível máximo holocênico, alcançado por volta de 5 ka AP. A partir de padrões de transporte e retrabalhamento sedimentar deduzidos com base em estatísticas da distribuição granulométrica (tamanho médio, seleção, assimetria), combinadas com variação dos índices de minerais pesados (iINS, iMET, iZTR, iTZ, iHT, iRZ), infere-se progradação da planície de Campos Verdes para norte, com componente de crescimento longitudinal para oeste, e da planície do Ji para leste, com componente longitudinal para norte. A distribuição dos minerais pesados deve-se em parte a mudança/aproximação, no decorrer do tempo, da fonte representada pelo delta do Tubarão, com entrada crescente de sedimentos menos maturos no sistema.

A evolução da planície de Campos Verdes foi dividida em cinco estágios cronológicos:

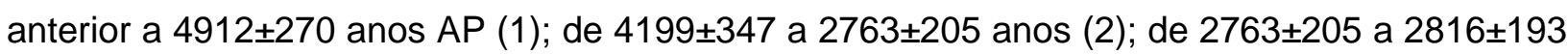
anos (3); de $2816 \pm 193$ a $1946 \pm 141$ anos (4); e desde $1946 \pm 141$ anos até o presente (5); com taxas de progradação de 1,07, 0,35, 3,45, 0,76 m/a e indeterminada, respectivamente. 0 estágio 4 compreende fase de estabilização de dunas eólicas, com lobo deposicional datado em $2255 \pm 123$ anos, e o estágio 5 inclui fase de reativação deflacionar, com duna parabólica faminta datada de $711 \pm 64$ anos. Para a planície do Ji, definiram-se cinco estágios cronológicos: anterior a $2794 \pm 151$ anos (1); de $2794 \pm 151$ a $2537 \pm 140$ anos (2); de $2537 \pm 140$ a $1031 \pm 35$ (3); de $1031 \pm 35$ a $831 \pm 43$ anos (4); e desde $751 \pm 43$ anos até o presente (5). As taxas de progradação calculadas para os últimos quatro estágios foram de 2,26, 0,28, 1,47 e 1,24 m/a, respectivamente. A fase de estabilização de dunas da geração eólica 3, datada em $1346 \pm 73$ 
anos, aconteceu durante o estágio 3. Campos de dunas transgressivos ainda ativos iniciaram seu desenvolvimento durante o estágio 5 .

O crescimento das duas planícies ocorreu em anti-fase, com alternância entre duas situações: a situação 1 caracteriza-se por predominância de deriva litorânea rumo NE, relacionada a incursões mais freqüentes de frentes frias e massa de ar polar na região; a situação 2 corresponde a dominância de deriva litorânea rumo SW, sob maior ação da massa tropical Atlântica e menor freqüência de incursões de frentes frias. Um "boom" na progradação de ambas as planícies, registrado por volta de 2700 anos AP, pode estar relacionado à ocorrência de um dos eventos climáticos de escala milenar do Holoceno, o evento Bond 2, caracterizado na região por aumento pontuado de umidade e precipitação e, por extensão, de aporte fluvial. O desenvolvimento ou reativação de dunas do estágio 5 em Campos Verdes pode estar ligado à intensificação dos ventos durante outro evento de escala milenar, a Pequena Idade do Gelo.

Fluxos da ordem de $10^{4} \mathrm{~m}^{3} / a n o$ foram obtidos em simulação estocástica de um cenário geral de trocas de sedimentos entre compartimentos (eg. praia e campo de dunas) no Ji. $\mathrm{Na}$ simulação condicionada por variáveis climáticas, observa-se que o transporte eólico, com desenvolvimento de campos de dunas, pode ocorrer mesmo durante períodos chuvosos (precipitação média superior a 400mm), desde que os fluxos eólicos sejam dez vezes maiores que os obtidos na simulação do cenário geral.

Palavras-chave:

cordões litorâneos, dunas eólicas, taxas de progradação, granulometria, minerais pesados 


\section{INTRODUÇÃO}

A partir do Holoceno médio e durante o Holoceno tardio, extensas planícies costeiras com cordões litorâneos formaram-se ao redor do globo. No hemisfério sul, o desenvolvimento de planícies de cordões foi favorecido pela queda do nível relativo do mar (NRM), após seu máximo holocênico (Isla 1989), e tem sido objeto de estudos sedimentológicos e/ou estratigráficos em diferentes setores costeiros da Austrália (Roy et al. 1994, Bristow et al. 2006, Brooke et al. 2008), Nova Zelândia (Woodroffe et al. 1983), África austral (Blivi et al. 2002) e Argentina (Isla \& Bujalesky 2000). No Brasil, destacam-se, entre outras regiões estudadas, a foz do rio São Francisco, SE/BA (Dominguez et al. 1983), a foz do rio Paraíba do Sul, RJ (Dias \& Kjerfve 2009), a llha Comprida, SP (Giannini et al. 2003, 2009, Sawakuchi et al. 2008, Guedes 2009), as planícies adjacentes à baía de Paranaguá, incluindo a llha do Mel, PR (Angulo et al. 1996, Lessa et al. 2000, Angulo et al. 2009), a região de Tijucas e Navegantes, SC (Fitzgerald et al. 2007), a enseada da Pinheira, SC (Hesp et al. 2009) e a planície litorânea do Rio Grande do Sul a norte de Tramandaí (Tomazelli \& Villwock 2005, Dillenburg et al. 2009). Nestas regiões, o registro de progradação mais ou menos continuada deve-se à manutenção de taxa de aporte sedimentar superior à de geração de espaço de acomodação por variação de NRM. O desenvolvimento destas planícies teria começado assim durante a desaceleração da taxa de subida de NRM, pouco antes do nível máximo, alcançado por volta de 5000 anos AP (Suguio et al. 1985, Martin et al. 1988, Angulo et al. 2006) e continuado no período subseqüente de queda de NRM.

Localizadas em Laguna, Santa Catarina, as planícies de Campos Verdes e do Ji representam exemplos relativamente bem preservados de cordões litorâneos formados em regiões vizinhas, porém sob condições distintas quanto ao contexto hidrodinâmico: em área protegida (de retrobarreira), em Campos Verdes, versus em tômbolo de mar aberto, no Ji. Estas semelhanças e diferenças entre as duas áreas tornam propícia a comparação entre elas, do ponto de vista da evolução sedimentar. Se, numa comparação desse tipo, os fatores regionais de controle da sedimentação, como nível relativo do mar (NRM) e clima, atuam de modo igual nas duas áreas, fatores mais locais, como aporte, energia de circulação (incluindo deriva litorânea) e espaço de acomodação podem agir de modo diferente de uma área para outra. Este tipo de situação favorece a avaliação da influência destes últimos fatores nas taxas e geometrias de progradação e reveste-se portanto de interesse no estudo da morfodinâmica de preenchimento de bacias costeiras. Existem outras particularidades e questões que tornam estas duas áreas apropriadas para o desenvolvimento de um Mestrado em sedimentologia costeira do Quaternário. Em primeiro lugar, trata-se das principais (e, praticamente, das únicas) planícies costeiras com expressão de feixes de cordões litorâneos no trecho do litoral sul catarinense entre Jaguaruna e Imbituba. Assim, em meio a uma costa 
dominada por campos de dunas livres sobre estreitas planícies e barreiras transgressivas, com linha de costa quase estável durante a segunda metade do Holoceno, é relevante entender que conjunção de variáveis teria determinado o desenvolvimento local de duas planícies com tão acentuada progradação. Em segundo lugar, as duas planícies oferecem oportunidade para estudar os padrões de variação de atributos sedimentológicos no decorrer de processos progradacionais, assunto ainda pouco explorado na costa brasileira e, em particular, no estudo do litoral catarinense. Em terceiro lugar, em ambas as planícies, cordões litorâneos alternam-se com campos de dunas livres (Giannini 1993, 2007), em disposição espacial sugestiva da intercalação no tempo entre pulsos de evolução progradacional e episódios de deposição eólica, que pode ser considerado chave para a compreensão das relações entre migração da linha de costa e iniciação e crescimento de campos de dunas eólicas.

No âmbito arqueológico, as planícies selecionadas destacam-se por situar-se em meio a uma das mais significativas áreas de registro da cultura sambaquieira no país, tanto em termos de quantidade como de dimensões dos sítios (Giannini et al. 2005, 2010, DeBlasis et al. 2007). A título de exemplo, pode-se citar os sambaquis do Canto da Lagoa e Carniça I, II e III situados sobre uma faixa de orientação NW-SE imediatamente a SW da planície de cordões de Campos Verdes (De Blasis et al. 2007, Tanaka 2007). Alguns destes sambaquis apresentam areia, em vez de conchas, como matéria-prima principal.

A análise dos padrões de variação de atributos sedimentológicos no decorrer de processos progradacionais é assunto ainda pouco explorado na investigação deste litoral. Estudos que relacionam a variação de índices de minerais pesados, baseados em Morton \& Hallsworth (1994, 1999), com mudanças na dinâmica costeira em escala de tempo milenar são escassos na literatura mundial.

Dentro deste contexto, a proposta central desta Dissertação de Mestrado é comparar e correlacionar as planícies de Campos Verdes e Ji quanto a geometria, rumo e taxas de crescimento progradacional, bem como quanto a padrões de variação granulométrica e de índices de minerais pesados, de modo a inferir os possíveis controles exercidos por variáveis macroambientais (clima, NRM) e pela dinâmica sedimentar sobre a formação dos cordões litorâneos e das dunas ativas e estabilizadas. O tema pode ser considerado chave para compreender melhor as relações entre mudanças da linha de costa e desenvolvimento de dunas eólicas neste setor do litoral brasileiro, com implicações indiretas no estudo da ocupação da região pela população sambaquieira. 


\section{CENÁRIO REGIONAL}

\subsection{Depósitos sedimentares quaternários}

A planície retrobarreira de Campos Verdes e a planície do Ji fazem parte de cenário regional (Fig.2.1) caracterizado pela justaposição de quatro tipos de sistemas deposicionais costeiros: o lagunar, o barreira, o planície de cordões (strandplain) e o eólico (Giannini 1993, 2002, Giannini et al. 2007).

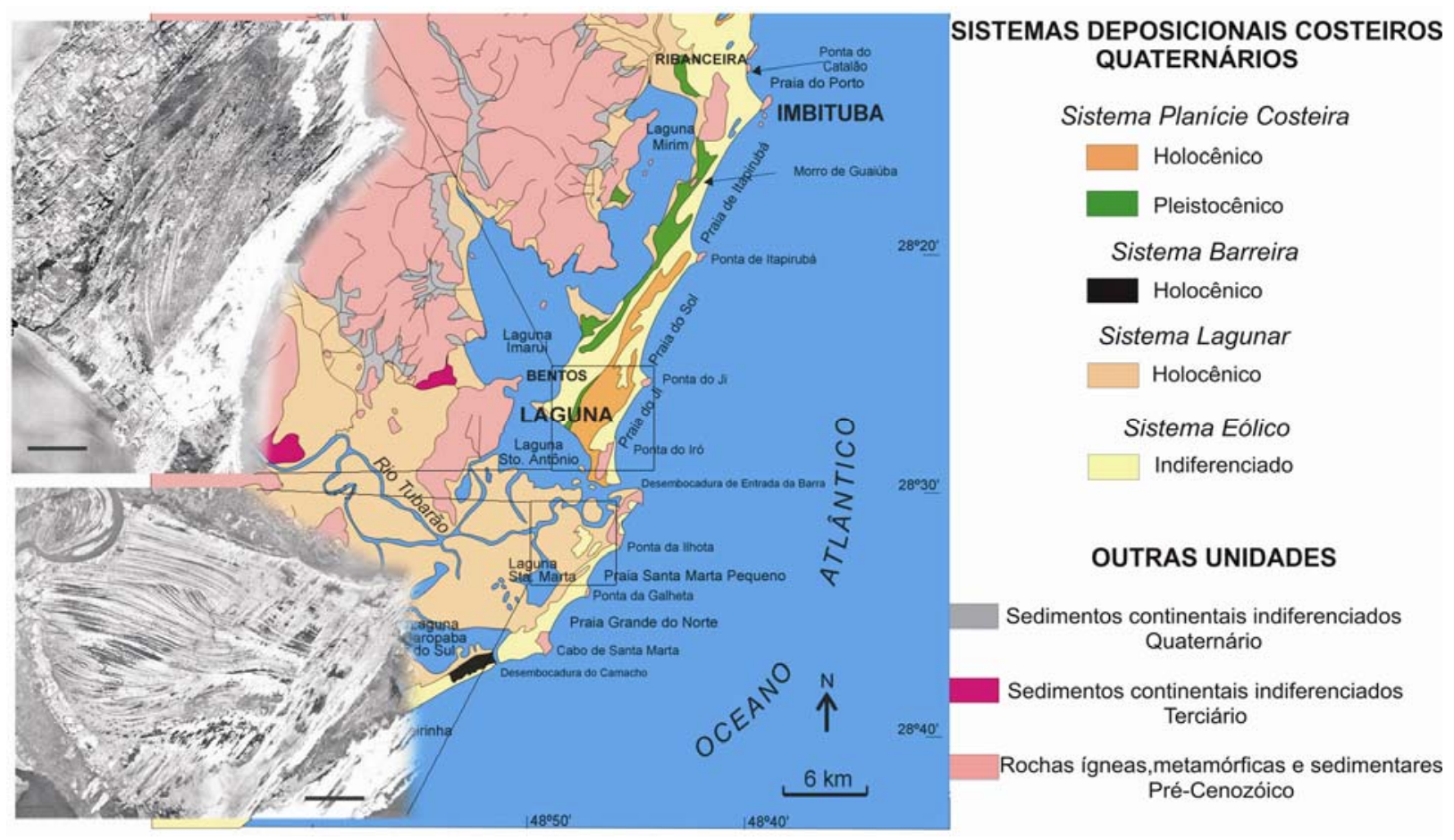

Figura 2.1 - Localização das áreas de estudo em relação aos sistemas deposicionais entre Jaguaruna e Imbituba (SC). Simplificado de Giannini (1993) por Giannini \& Santos (1994). Aereofotografias dos vôos de 1956 da Cruzeiro do Sul Serviços Aéreos.

O sistema lagunar é caracterizado por duas associações de fácies, a baía-laguna (sensu Fisher e McGowen 1967) e a vale-laguna, que correspondem respectivamente ao isolamento parcial de corpo de água por crescimento de uma barreira transgressiva e ao afogamento de vales previamente formados por dissecação em terraços marinhos regressivos do Pleistoceno (Giannini 2002, Giannini et al. 2001, 2005). O contexto transgressivo de formação simultânea de ambas as associações relaciona-se à elevação de NRM holocênico, cujo pico foi atingido na região por volta de 5400 anos ${ }^{14} \mathrm{C}$ cal A.P. (Angulo et al. 1996, 1999, 2006). A principal particularidade faciológica da associação baía-laguna é a foz do rio Tubarão, compondo o maior delta interior ativo do território brasileiro (Giannini 1993, 2002).

O sistema barreira é formado por sedimentos arenosos holocênicos e isola, à retaguarda, o complexo de lagunas intercomunicáveis entre as lagoas Santo Antônio e 
Garopaba do Sul. Corresponde a barreira de origem inicial transgressiva, formada sob contexto de desaceleração da subida de NRM (Giannini 1993; Giannini et al. 2001, 2005). Apesar desta origem transgressiva, fase regressiva posterior tem sido admitida como hipótese, com base na sua largura relativamente grande (até $2 \mathrm{~km}$ ) em comparação com barreiras transgressivas do hemisfério norte. No entanto, maior parte da barreira é coberta por campos de dunas, o que obliteraria em superfície eventuais cordões regressivos. A dinâmica erosivo-deposicional do sistema é marcada também pela sucessão de fenômenos de sobrelavagem e de abertura, fechamento e migração de desembocaduras (especialmente Camacho), inclusive em tempo histórico (Giannini 1993, 2002).

Depósitos pleistocênicos e holocênicos constituem o sistema planície de cordões (strandplain). Neste sistema, diferentemente do barreira, não há corpo lagunar contíguo que possa a ele relacionar-se geneticamente (Giannini 1993, 2002). O corpo de água a retaguarda da planície de cordões pleistocênica corresponde mais provavelmente a vales afogados (valelaguna).

O sistema deposicional eólico superpõe-se aos sistemas barreira e planície de cordões em grande parte da área, definido por quatro gerações de depósitos (Giannini 1993). As gerações eólicas 1 e 2 foram correlacionadas, respectivamente, aos máximos transgressivos do Pleistoceno superior e do Holoceno. A geração 3 teria sido formada nos últimos séculos a milênios, em tempos pós-máxima inundação holocênica. E a geração 4 corresponde às dunas ativas (Giannini 1993, 2002, Giannini et al. 2001, 2005).

A planície de Campos Verdes insere-se neste contexto de sistemas deposicionais costeiros como feição de interface entre a baía-laguna e a barreira. Já a planície do Ji integra o sistema planície de cordões holocênico, ancorado em paleodunas da geração eólica 2 adjacentes à vale-laguna, a W, e no morro do Mar Grosso, a S (Giannini 1993).

\subsection{Clima, ventos, ondas, marés e aporte fluvial}

A costa sul de Santa Catarina está localizada na Zona Subtropical Sul (Stranhler 1977). De acordo com a classificação de Köppen, o clima é do tipo Cfa (Monteiro 1958) mesotérmico a subtropical úmido. A umidade relativa na região de Imbituba-Jaguaruna é de aproximadamente 85\%, com taxa de precipitação média anual de $1250 \mathrm{~mm}$ (Imbituba) a 1400 mm (Laguna). A dinâmica climática é controlada pelo anticiclone tropical do Atlântico sul que favorece os ventos alísios provenientes de NE e o anticiclone migratório polar. A migração para norte do anticiclone polar pode gerar frentes frias com instabilidade e aumento da precipitação e geração de ciclones com ventos de S e SW (Nimer 1966, 1979).

Atualmente, mudanças meteorológicas no Sul e Sudeste do Brasil são correlacionadas à formação, passagem ou intensificação de frentes frias, sistemas 
meteorológicos atuantes em latitudes médias da costa brasileira ao longo do ano (Kousky 1979, Satyamurty et al. 1998, Rodrigues et al. 2004). Os sistemas frontais estão associados a perturbações de larga escala e movem-se junto a ciclones e anticiclones responsáveis pela alteração das zonas de pressão atmosférica, ventos e outras variáveis atmosféricas ao longo de sua trajetória (Wallace \& Hobbs 1977, Rodrigues et al. 2004). A incursão de massas de ar polar rumo norte, no Brasil subtropical, tornaram-se mais freqüentes e intensas durante o último máximo glacial devido à acentuação dos gradientes latitudinais de temperatura relacionada ao fortalecimento dos ciclos de insolação de precessão (Cruz et al. 2006).

Segundo cálculo e análise de potenciais de deriva eólica realizados por Giannini (1993), em Laguna a deriva eólica potencial concentra-se no verão (39\%) seguido do inverno (27\%), sendo que os ventos de S-SW (53\%) e de N-NE (41\%) são os mais importantes. Os ventos de S-SW atuam preferencialmente no verão, outono e início do inverno com coincidência de $70 \%$ com dias de chuva; já os ventos de N-NE são mais atuantes no final do inverno e na primavera. Os campos de dunas transgressivos da região migraram dominantemente para SW desde o Holoceno até o presente, como observado por Giannini et al. $(2005,2007)$ através de indicadores geomorfológicos.

Dois sistemas de ondulações (swell waves) operam na costa sul de Santa Catarina. O S-SE é o mais intenso, gerado por massa de ar polar e frentes frias, enquanto o de E-NE, relacionado aos ventos alísios, é o segundo mais importante (Giannini 1993, Giannini et al. 2005, Hesp et al. 2009). As ondas possuem em média alturas de 1,0 a 1,5m, de acordo com uma análise do registro ondográfico, a $35 \mathrm{~km}$ costa afora da llha de Santa Catarina.

Esses dois sistemas de ondulações, associados à orientação da linha de costa, são responsáveis pelo padrão de transporte por deriva litorânea com sentidos opostos. No entanto, existe o predomínio do transporte para NE, indicado por feições geomorfológicas e dados sedimentológicos (Giannini 1993, 2002, Martinho 2004).

De acordo com a tábua de marés do Porto de Imbituba, a amplitude média de maré astronômica de sizígia é da ordem de $0,6 \mathrm{~m}$, classificada como regime de micromaré com irregularidades diurnas (Giannini 1993).

A região é drenada pela bacia hidrográfica dos rios Tubarão e Una-Aratingaúba, ambos com desague nas lagunas retrobarreira (Fig.2.1).

\subsection{Morfodinâmica praial}

As praias do setor entre Laguna e Imbituba são predominantemente dissipativas. A face praial é plana e com inclinações suaves $\left(<1^{\circ}\right)$, sem berma e com frequentes falésias em dunas transversais e dunas frontais (Giannini et al. 2007). A classe granulométrica modal para 
os sedimentos de praia é areia fina (segundo a classificação de Wentworth), dentro do intervalo entre 2 e $3 \phi$. A areia é essencialmente terrígena (Giannini 1993).

\subsection{Nível relativo do mar (NRM)}

$\mathrm{Na}$ escala de dezenas de metros e milhares de anos, duas fases mais recentes de nível relativo de mar (NRM) alto são identificadas com base em terraços de construção emersos em grande parte da costa brasileira, incluindo Santa Catarina (Suguio et al. 1988, Martin et al. 1988, Corrêa 1996, Angulo \& Lessa 1997, Angulo et al. 1999). A primeira destas fases ocorreu por volta de 120 mil anos AP (Pleistoceno tardio), quando o NRM atingiu $8 \pm 2 \mathrm{~m}$ acima do nível do mar atual (Martin et al. 1988) em toda costa leste do Brasil. Esta fase foi seguida de queda do NRM durante o último máximo glacial, chegando em 18 mil anos AP a aproximadamente 130m abaixo do atual (Corrêa 1996). Após o último período glacial, o NRM voltou a aumentar (Van Andel \& Laborel 1964, Suguio et al. 1985), apresentando três fases estacionárias, por volta de 11, 9 e 8 mil anos AP (Kowsmann \& Costa 1979, Corrêa 1996).

A compilação e reinterpretação de dados de vermitídeos do leste do Brasil indica diminuição do NRM desde cerca de 5 mil anos AP até o presente (Fig.2.2, Angulo et al. 2006). Níveis do mar pretéritos e idades ${ }^{14} \mathrm{C}$ de vermitídeos obtidas por Angulo et al. (1999) na zona costeira de Imbituba-Laguna indicam declínio de NRM, após um nível máximo do mar holocênico de 2,1 $\pm 1,0 \mathrm{~m}$ que durou algumas centenas de anos entre 5800 e 5000 anos cal AP (Angulo et al. 2006). De acordo com Angulo et al. (2006), este padrão de variação coincide com as previsões baseadas em modelo realístico de flutuações de nível do mar induzidas por glácio-isostasia (Milne et al. 2005), o qual sugere o alcance de um nível de mar alto entre 7 e 5 mil anos AP, seguido de estabilização relativa, com queda suave, após 5 mil anos AP.

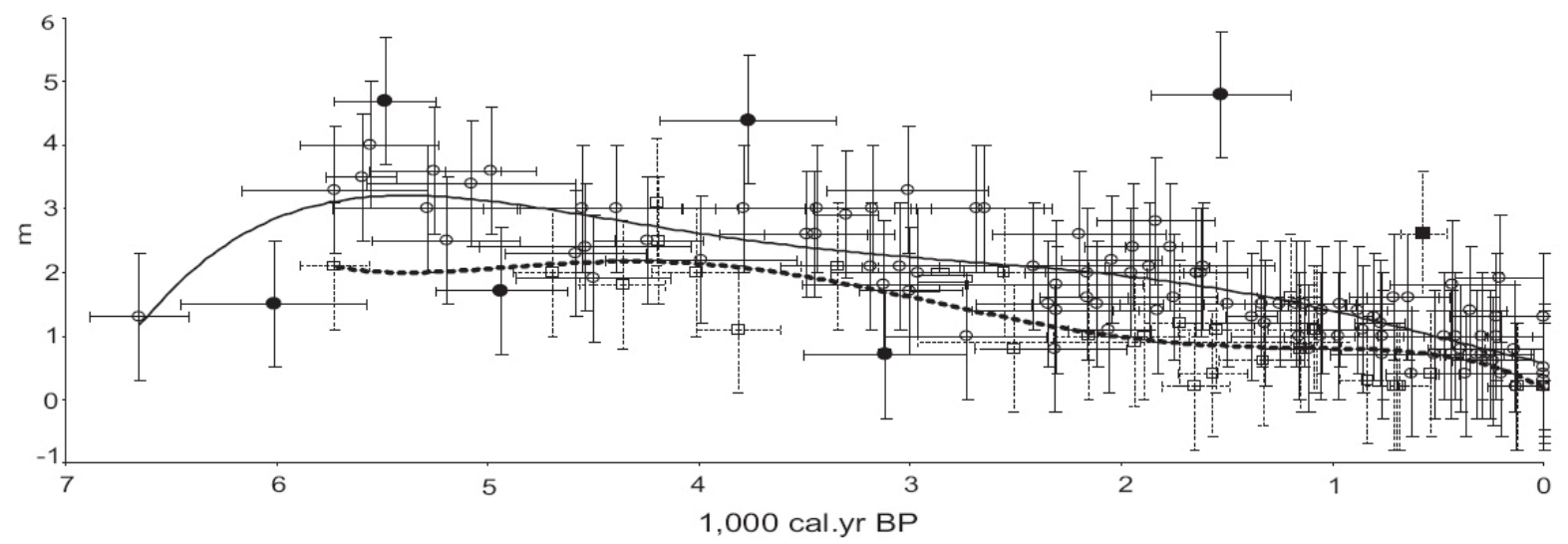

Figura 2.2 - Curva de nível relativo do mar (NRM) no Brasil, do Holoceno médio ao presente. O polinômio de $5^{\mathrm{a}}$ ordem ajustado aos dados representa o padrão médio do paleonível do mar; quadrados vazios e linha tracejada correspondem aos dados de Santa Catarina; círculos vazios e linhas cheias representam dados de outros setores da costa do Brasil; círculos e quadrados preenchidos são outliers. Extraído de Angulo et al. (2006). 


\section{METAS E OBJETIVOS}

As metas desta dissertação devem ser entendidas como desafios maiores e mais pretensiosos da pesquisa. Nesse sentido, três metas principais são propostas:

1) Construir um modelo geral de variação de atributos sedimentológicos em planícies de cordões, com base na comparação dos resultados obtidos em Campos Verdes e no Ji com os dados prévios similares de outras planícies da costa sul-sudeste brasileira.

2) Explicar a origem e mecanismo dos processos formadores e remodeladores dos alinhamentos de cordões das duas áreas de estudo e avaliar sua influência nas respectivas taxas de progradação.

3) Compreender o modo como os vários feixes de alinhamentos de cordões se relacionam aos depósitos eólicos.

De forma a alcançar essas metas, foram estabelecidos os seguintes objetivos específicos:

1) Delimitar conjuntos de alinhamentos de cordões concordantes a partir da reconstituição dos padrões de truncamento, através de fotointerpretação em escalas 1:25.000 e/ou de mais detalhe.

2) Verificar a expressão topográfica dos conjuntos de alinhamentos no campo.

3) Caracterizar o padrão de variação de atributos sedimentológicos (granulométricos e mineralógicos) em perfil transversal aos feixes de alinhamentos de cordões.

4) Caracterizar o padrão de variação de atributos sedimentológicos (granulométricos e mineralógicos) ao longo de alinhamentos de cordões determinados, de modo a inferir o possível rumo de transporte dominante por paleoderiva longitudinal, em ambas as planícies.

5) Situar os conjuntos de cordões e a variação sedimentológica no tempo, através de datações absolutas por luminescência, e calcular taxas de progradação.

6) Comparar o conjunto de dados obtidos para as duas planícies de cordões, com o intuito de verificar possíveis correlações por efeito de fatores alogênicos ("alocíclicos") comuns.

7) Avaliar, através de simulação numérica, a influência do regime de ventos e chuvas sobre o desenvolvimento da praia e campos de dunas do Ji.

\section{FUNDAMENTAÇÃO TEÓRICA}

\subsection{Evolução do conhecimento sobre a região}

As primeiras referências sobre os cenários da região de Laguna foram feitas sob o enfoque arqueológico (Abreu 1928) e geomorfológico (Guerra 1950), onde se descreveram, 
respectivamente, os sambaquis e os depósitos sedimentares quaternários da região. Estes últimos foram apresentados sob a forma de mapa simplificado de distribuição faciológica, no qual o autor separa as fácies em "planícies litorâneas" e "banhados".

Com o intuito de definir um local para construção de um porto carbonífero no sul de Santa Catarina, Pimienta (1958) descreveu detalhadamente, sob enfoque predominantemente geológico, a faixa costeira meridional do estado, incluindo estudos granulométricos das areias litorâneas e uma proposta de modelo de evolução sedimentar para a região de Laguna. Este autor atribuiu a formação da planície litorânea à regressão que sucedeu a "Transgressão Flandriana" e supôs idade holocênica para os sedimentos da planície. Sugeriu a existência de relações entre a fase atual de ativação de dunas eólicas e suposta tendência para a estabilização da linha de costa e diagnosticou o papel dos "ventos alternados de S e NE", os primeiro mais intensos e os últimos mais freqüentes, na determinação de rumos de deriva litorânea longitudinal e deriva eólica, respectivamente.

A região costeira de Imbituba a Jaguaruna e arredores foi objeto de trabalhos de cartografia geológica executados pelo Departamento Nacional de Produção Mineral (DNPM) entre o final da década de 1960 e início da década de 70. O conjunto de obras publicadas nesse período não modificou, todavia, o quadro evolutivo sedimentar apresentado por Pimienta (1958). Este só iria começar a ser questionado a partir do trabalho de Bigarella (1975), que apontou para a existência de dunas eólicas costeiras pleistocências em Guaiúba, a sul da cidade de Imbituba.

Na década de 80 , através de estudos sistemáticos baseados em modelo de variação do NRM em grande parte da costa brasileira (Suguio et al. 1985), reconheceu-se na região a presença de terraços marinhos pleistocênicos. Com base nisso, Martin \& Suguio (1986) e Martin et al. (1988) conceberam um novo esquema evolutivo para a costa de Santa Catarina e apresentaram mapas da cobertura sedimentar, em escala 1:150.000 a 1:200.000, em que as unidades quaternárias foram separadas quanto a idade (holocênica, pleistocênica e indiferenciada), caracterização litológica e ambiente deposicional.

Através de uma análise conceitual da linguagem usada em teoria de sistemas aplicada à sedimentação costeira quaternária, Giannini (1993) reconheceu e descreveu quatro tipos de sistemas deposicionais na região do grande complexo lagunar centro-sul catarinense. A distribuição de fácies foi apresentada pelo autor em mapa geral em escala 1:100.000, com detalhamento 1:25.000 em áreas selecionadas. O uso de critérios geomorfológicos, morfoestratigráficos, texturais e mineralógicos auxiliou na caracterização de fácies deposicionais e na distinção entre sedimentos pleistocênicos e holocênicos, bem como permitiu a separação de quatro gerações de dunas eólicas, mais tarde discutida, detalhada (Giannini \& Suguio 1994, Giannini 1998, 2002; Giannini et al. 1997a, 2001; Martinho \& 
Giannini 2001) e confirmada por datações via luminescência (Sawakuchi 2003, Giannini et al. 2007).

Embora iniciado há mais tempo que as investigações sedimentológicas, o estudo arqueológico da região só começou a ser realizado de maneira sistemática a partir dos trabalhos de DeBlasis et al. (1998). Com enfoque interdisciplinar geologia-arqueologia, Tanaka (2007) e Menezes (2009) estudaram relações de proveniência entre um dos sambaquis arenosos de Carniça e as dunas e cordões de Campos Verdes. Com base em fotointerpretação, seções de GPR e análises granulométricas e mineralógicas, Tanaka (2007) e Tanaka et al. (2008, 2009a) propuseram um modelo preliminar de evolução sedimentar para a planície de Campos Verdes, segundo o qual os primeiros cordões litorâneos teriam sido ancorados sobre um paleopontal de areia (faixa sem cordões orientada segundo NW) e progradado rumo NE. O trabalho mais recente na interface geologia-arquelogia sobre a região (Giannini et al. 2010) classifica os sambaquis segundo critérios geográficos, de idade e composicionais, de modo que associa a formação dos sambaquis à evolução da paisagem.

\subsection{Cordões litorâneos, taxas de progradação e sedimentação eólica}

Os cordões litorâneos das planícies de Campos Verdes e Ji (Fig.4.1) atendem à definição abrangente dada ao termo beach ridges por Otvos (2000): "formas reliquiares, semiparalelas, em alinhamentos múltiplos, que podem ser originadas tanto por ondas, como pelos ventos". Idealmente, a progradação materializa-se em sucessão de cordões litorâneos subparalelos e contínuos, registro de sucessivas linhas de costa (Giannini et al. 2005; Hesp et al. 2005). O espaçamento entre cordões depende da velocidade de progradação, da freqüência de tempestades e do nível relativo do mar (Hesp et al. 2005).

Os alinhamentos da planície do Ji exemplificam o tipo clássico de feixe de cordões litorâneos, formado junto a mar aberto. Os alinhamentos da planície retrobarreira de Campos Verdes, considerados por Giannini (1993) "cordões lagunares" de gênese similar aos cordões de costa aberta, também se incluem na categoria de "cordões litorâneos" (beach ridge), sensu Hesp $(1984,1999)$ e Hesp et al. (2005), que restringe o termo às formas geradas por ondas (em contraposição aos foredune ridges), e inclui entre elas aquelas "relacionadas à variação do nível médio das águas de lagunas e estuários" (Hesp et al. 2005), ainda que esta variação não seja imprescindível para explicar sua gênese. A origem subaquosa dos cordões de Campos Verdes foi aqui admitida em vista de ausência, nos dados de GPR e de campo, de qualquer indício de deposição eólica na forma de dunas frontais (Tanaka et al. 2009a). Nas trincheiras e exposições, as estruturas sedimentares são raramente preservadas, mas, quando identificadas, correspondem a estratificações plano-paralelas incipientes, que podem ser atribuídas a espraiamento de ondas. Com base nestes dados, as cristas identificadas em 
foto aérea e no campo foram admitidas como fácies morfológica de cordão litorâneo no sentido estrito, de Hesp et al. (2005), e as depressões como fácies de intercordão.

Em campo, a diferença entre as cristas (cordões sensu stricto) e as depressões (intercordões) é tênue, dada por ondulação topográfica suave, de desnível decimétrico. Esta diferença pode tornar-se nítida graças a contrastes entre vegetação de porte maior, arbustiva a arbórea, nas cristas, e vegetação dominada por gramíneas, nas depressões frequentemente alagadas (Fig.4.1).

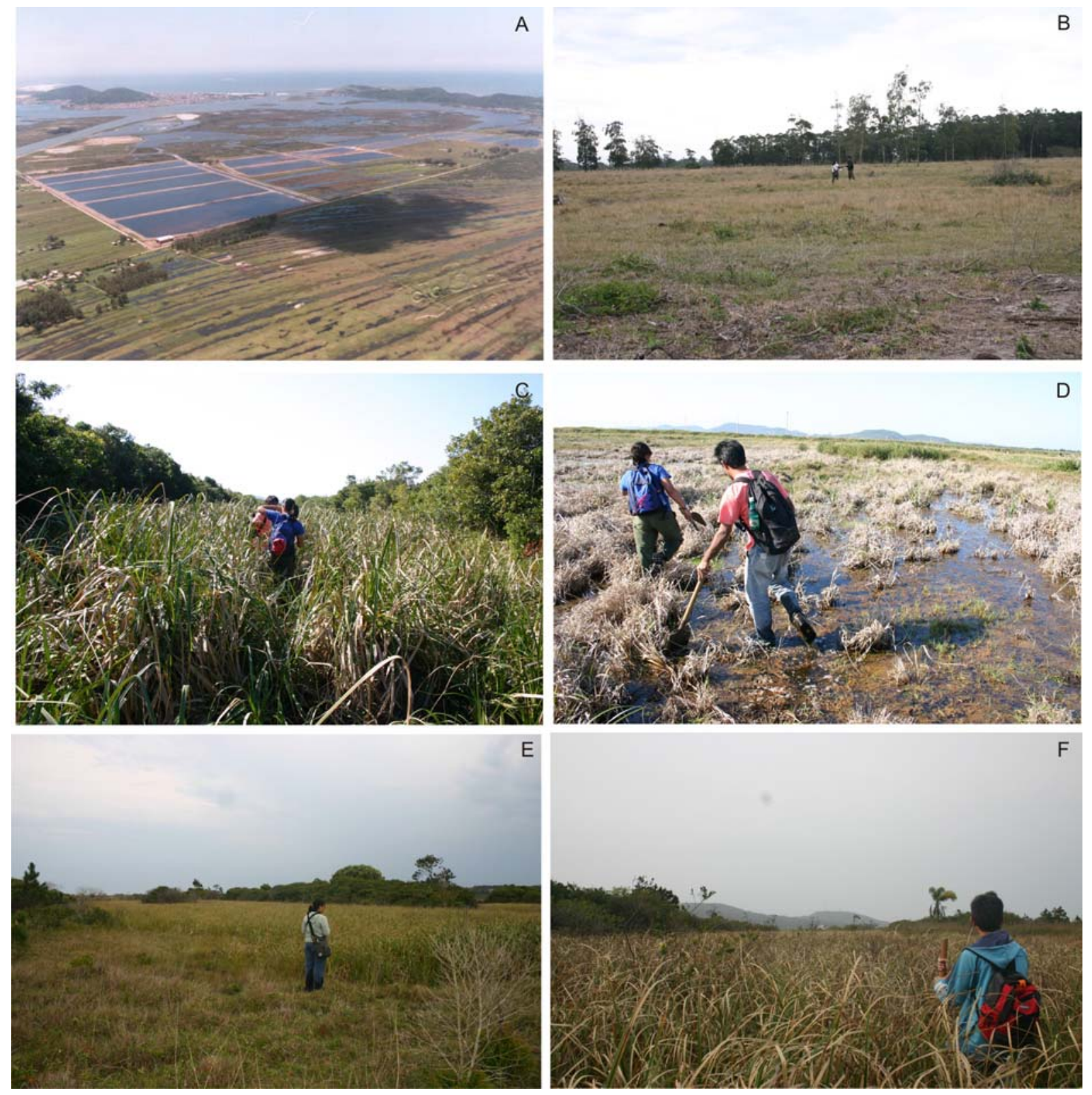

Figura 4.1 - Aspecto de campo dos cordões litorâneos de Campos Verdes (A a D) e Ji (E e F). A) Vista aérea oblíqua da porção sudoeste da planície de cordões (primeiro plano) e da desembocadura do rio Tubarão, com os morros de Laguna e Passagem da Barra, ao fundo (Foto Bacha, Laguna, 2001). B) Cordões paralelos com gradiente topográfico decimétrico entre crista e depressão, cobertos por vegetação rasteira. C) Vegetação dominada por gramínea (Scirpus maritimus L.), em depressão intercordões (centro da foto), em contraste à vegetação arbórea, nas cristas. D) Depressão intercordões alagada. E) Cordões paralelos ressaltados pelo contraste entre vegetação rasteira e arbórea. F) Cordões, com intercordão no centro da foto, em vista para sul (rumo Morro do Mar Grosso, ao fundo). Modificado de Tanaka et al. (2009a). 
Flexor et al. (1984) propõem um modelo para a formação de sucessões de cordões litorâneos, onde a deposição no prisma praial seria acarretada em resposta ao desequilíbrio provocado pelo abaixamento do NRM, num mecanismo análogo e recíproco ao previsto pelo princípio de Bruun (1962). O novo equilíbrio seria caracterizado pelo aporte de sedimentos das áreas de antepraia para o prisma praial. Os cordões litorâneos consistiriam assim de antigas altas praias, abandonadas durante progradação da linha de costa "causada por rebaixamento do NRM" (Flexor et al. 1984). Esta última afirmação implica relação de causa e efeito entre NRM e formação de cordão, de modo que outras variáveis controladoras da progradação da linha de costa (por exemplo: aporte vindo do continente) são tacitamente admitidas pelos autores como constantes.

Relações de causalidade deste tipo, entretanto, não resistem a uma análise mais sistêmica, em que se contemple o fato de que a mudança de posição da linha de costa não depende simplesmente do NRM, mas é função da relação entre aporte sedimentar (As) e espaço de acomodação da bacia sedimentar (Ea), este sim controlado pelo NRM (Giannini et al. 2005). A variação Ea pode ser negativa (NRM em queda), nula (NRM estável) ou positiva (NRM em ascensão), de tal modo que o preenchimento só pode progradar e a linha de costa regredir quando o aporte As suplantar a criação de espaço Ea.

As taxas de aporte sedimentar são, por sua vez, controladas por fatores sub-regionais e locais como o aporte fluvial e as correntes de deriva litorânea induzidas por onda, ou sua interação com correntes de marés em desembocaduras lagunares; estes fatores podem variar de modo abrupto ou episódico em uma escala de tempo de dezenas a centenas de anos. Inversões locais temporárias como as representadas na área por mudanças autocíclicas de posição da foz do delta do rio Tubarão e fechamento, abertura e migração da desembocadura do Camacho caracterizam áreas de equilíbrio erosivo-deposicional instável, como é o caso da planície lagunar retrobarreira de Campos Verdes (Giannini et al. 2005). O padrão de truncamento e a sucessão dos cordões de Campos Verdes são, portanto, registros de variações na relação entre as taxas As e Ea, em que não só o NRM, mas o aporte local deve ter exercido grande influência.

Mesmo em planícies de cordões adjacentes a praias oceânicas, como a do Ji, inversões de deriva litorânea e alterações de aporte no equilíbrio praia-duna podem provocar mudanças sutis de orientação e espaçamento entre cordões.

O que se pode abstrair desta releitura do modelo de Flexor et al. (1984) é que flutuações mais ou menos marcadas de NRM e/ou de aporte são as responsáveis pela individualização dos cordões. Desse modo, a progradação de planícies de cordões em geral pode ser considerada resultante de uma sucessão de eventos episódicos, com fases deposicionais separadas entre si por períodos de erosão, estes muitas vezes manifestados 
por truncamentos entre feixes de cordões ou falésias soterradas. Essa hipótese é favorecida pela ideia de que a sedimentação é tipicamente um processo descontinuo e não uniforme (Sadler 1981, Hsu 1983, Ivanov 1996). A geometria e arranjo das feições geomorfológicas, observadas em aerofotointerpretação no $\mathrm{Ji}$ e, ainda mais claramente, em Campos Verdes, sugerem a alternância entre duas dinâmicas sedimentares: progradação da planície de cordões, sem expressão de atividade eólica significativa, e estabilização da linha de costa, com erosão costeira e desenvolvimento de campos de dunas livres (Fig.4.2) que transgridem os alinhamentos de cordões anteriores.
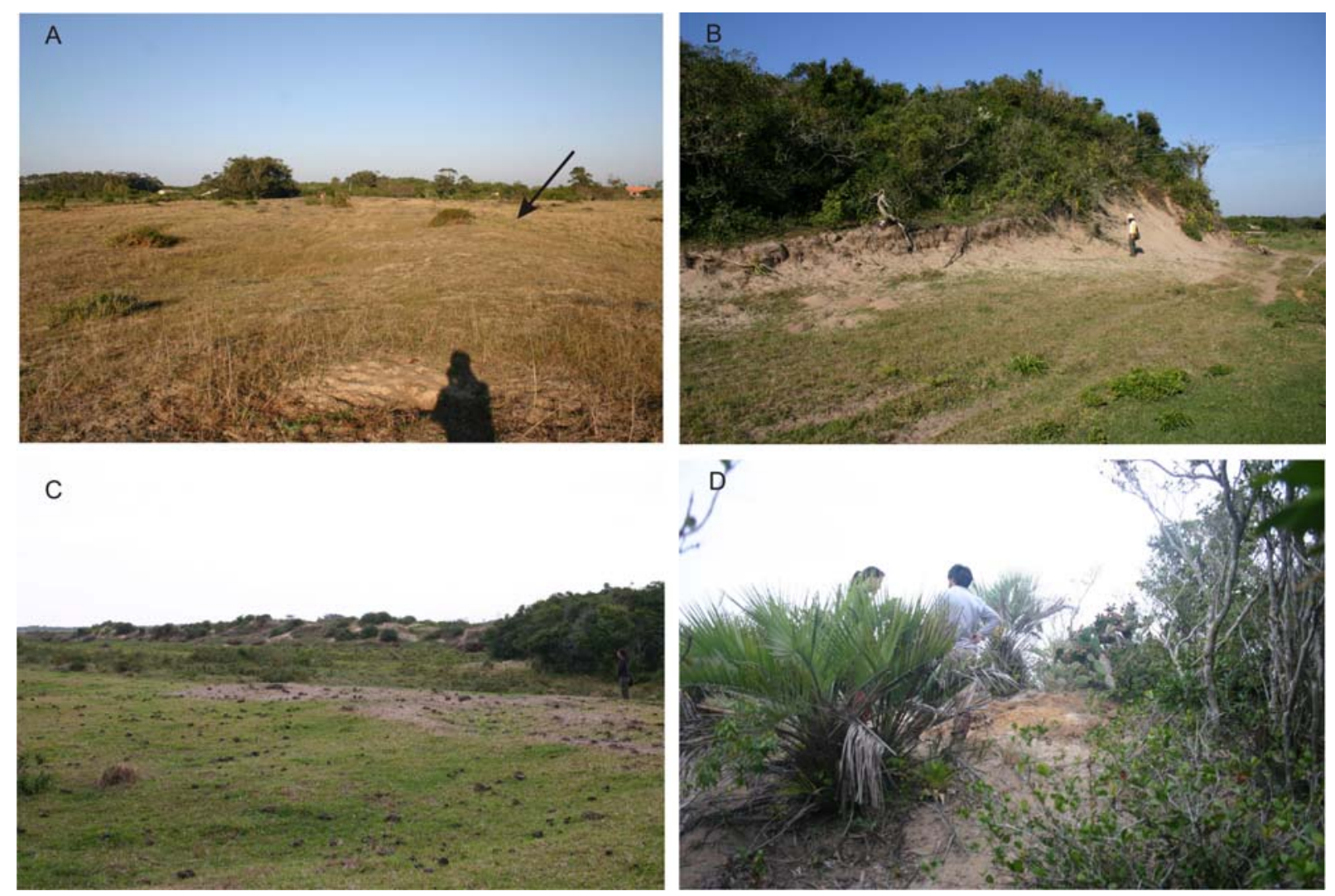

Figura 4.2 - Aspecto de campo das dunas eólicas de Campos Verdes e Ji. A) Frente de forma parabólica delgada em Campos Verdes. B) Depósitos eólicos no ponto CV.08, nas proximidades do sambaqui Carniça I. C) Campo de dunas na parte leste da planície de Campos Verdes, próximo à Estrada Geral. D) Lobo deposicional na planície do Ji. Adaptado de Tanaka et al. (2009a).

O advento das datações por luminescência e, nos últimos 15 anos, o refinamento metodológico da luminescência oticamente estimulada (LOE), têm permitido estimar, com boa confiabilidade, a taxa de progradação de planícies costeiras holocênicas em diferentes partes do globo, como Austrália, Brasil, Dinamarca e Estados Unidos (Murray-Wallace et al. 2002, Bentz 2004, Goodwin et al. 2006, Nielsen et al. 2006, Lopez \& Rink 2007, Sawakuchi et al. 2008; Tabela 4.1). 
Tabela 4.1 - Taxas de progradação de planícies de cordões litorâneos em locais diferentes no mundo, modificado de Sawakuchi et al. (2008).

\begin{tabular}{|c|c|c|c|c|}
\hline Local & $\begin{array}{c}\text { Taxas de progradação } \\
(\mathrm{m} / \mathrm{ano})\end{array}$ & $\begin{array}{c}\text { Intervalo } \\
(\text { anos A.P.) }\end{array}$ & $\begin{array}{c}\text { Método de } \\
\text { datação }\end{array}$ & Autor \\
\hline $\begin{array}{c}\text { St. Vincent Island } \\
\text { Florida, E.U.A }\end{array}$ & 0,9 & $\sim 4000-370$ & LOE & Lopez and Rink (2007) \\
\hline $\begin{array}{c}\text { Northern Jutland } \\
\text { Dinamarca }\end{array}$ & 2,0 & $\sim 2700-1000$ & LOE & Nielsen et al. (2006) \\
\hline $\begin{array}{c}\text { Guinchen Bay } \\
\text { South Autralia }\end{array}$ & 0,39 & $5400-51$ & LOE & $\begin{array}{c}\text { Murray-Wallace } \text { et al. } \\
(2002)\end{array}$ \\
\hline $\begin{array}{c}\text { Merrit Island } \\
\text { Florida, E.U.A }\end{array}$ & 1,35 & $4000-150$ & LOE & $\begin{array}{c}\text { Rink and Forrest } \\
(2005)\end{array}$ \\
\hline Iluka Bay, Australia & $0,9 \mathrm{e} 1,7$ & $3000-1000$ & LOE e ${ }^{14} \mathrm{C}$ & Goodwin et al. (2006) \\
\hline $\begin{array}{c}\text { Juréia, São Paulo, } \\
\text { Brasil }\end{array}$ & $1,05-2,09$ & $3580-0$ & LOE & Bentz (2004) \\
\hline $\begin{array}{c}\text { Ilha Comprida } \\
\text { São Paulo, Brasil }\end{array}$ & $0,21-2,03$ & $1700-50$ & LOE & Sawakuchi et al. (2008) \\
\hline
\end{tabular}

De acordo com a Tabela 4.1, taxas de progradação semelhantes podem ser observadas em planícies costeiras holocênicas de contexto climático e fisiográfico diferentes, o que pode indicar que a velocidade de crescimento destas planícies seja dominantemente controlada por variáveis alogênicas globais (Sawakuchi et al. 2008), por exemplo, o contexto comum de relativa estabilidade de NRM dentro dos últimos quatro a cinco milênios, pelo menos nas regiões exemplificadas.

\subsection{Propriedades sedimentológicas de cordões litorâneos}

A análise de atributos texturais e mineralógicos tem sido usada, no estudo de sedimentos costeiros quaternários do Brasil, tanto para a inferência da dinâmica local (Tessler 1982, 1988, Giannini 1987, 1993, Giannini et al. 2004, Nascimento Jr. et al. 2005), como para diferenciar arenitos ou areias de diferentes idades (Pettijohn 1941, Giannini 1993, Giannini \& Suguio 1994, De Mio \& Giannini 1997, Sawakuchi et al. 2009). Admitida a premissa de que os alinhamentos de cordões são resultado da progradação da linha de costa, sistemas de cordões litorâneos podem ser utilizados como registro da variação das propriedades sedimentológicas ao longo do tempo de duração do processo progradacional. Neste trabalho, testou-se a aplicação de ambas as possibilidades nas duas planícies selecionadas para estudo, em complemento e refinamento aos dados obtidos por Tanaka (2007) em Campos Verdes. Maior ênfase foi dispensada à interpretação de minerais pesados. Os pontos de partida para este tipo de estudo foram as premissas e princípios que se apresentam resumidos a seguir. 


\subsubsection{Granulometria}

Para a finalidade de inferência de rumo de transporte longitudinal e/ou crescimento progradacional, convém combinar a análise de variação mineralógica com o estudo de outros parâmetros sedimentológicos, por exemplo, granulometria.

De acordo com McLaren (1981), o tamanho do grão (diâmetro médio), a seleção (desvio padrão) e a assimetria de um depósito sedimentar são controlados pelas características da área fonte (rocha mãe) e pelos processos de erosão e seleção durante o transporte. Desse modo, McLaren (1981) propôs a existência de padrões de distribuição granulométrica encontrados entre a fonte e a deposição do sedimento. McLaren \& Bowles (1985) admitem a existência de dois padrões de variação combinada de estatística descritiva da distribuição granulométrica que indicariam inequivocamente o rumo de transporte ou de retrabalhamento sedimentar. Estes padrões são: "mais fino, mais selecionado, mais negativo" (diâmetro médio maior na escala phi, menor desvio padrão e assimetria mais negativa) e "mais grosso, mais selecionado, mais positivo" (diâmetro médio menor na escala phi, menor desvio padrão e assimetria mais positiva). Assim, a verificação de um destes dois tipos de variação em dado rumo espacial seria indicativa de transporte sedimentar nesse rumo. Os padrões de variação devem ter consistência estatística verificada.

O uso do método de McLaren \& Bowles (1985) combinado com a análise de variação espacial de minerais pesados de diferentes estabilidades e equivalentes hidráulicos têm possibilitado a inferência do rumo de transporte predominante e de crescimento progradacional para areias quaternárias (Giannini et al. 2003, 2004, Tanaka 2007, Tanaka et. al. 2008, 2009a, 2009b, Guedes 2009).

\subsubsection{Minerais pesados (MP)}

Apesar de constituírem fração menor na maioria das rochas e depósitos terrígenos, os minerais pesados são importantes por apresentarem assembléias variadas, capazes de "contar a história" da origem, transporte e deposição dos sedimentos. Quando devidamente identificados e quantificados, fornecem dados que podem ser aplicados em estudos relacionados a: i) proveniência, ii) identificação do padrão de dispersão e/ou transporte de sedimentos, iii) delimitação de províncias petrológicas, iv) correlação entre diferentes corpos de areia, v) indicação da ação de regimes hidráulicos particulares e respectivos processos de concentração, vi) localização de depósitos economicamente importantes e vii) inferência de processos diagenéticos (Mange \& Maurer 1992).

No contexto específico deste estudo, ressalta-se o uso da análise de minerais pesados como ferramenta para inferir a evolução das duas planícies de cordões litorâneos 
(crescimento lateral e progradacional, importância ii), identificar controles seletivos durante a dispersão dos sedimentos (importância v) e avaliar a influência de processos diagenéticos, com destaque para a dissolução química pós-deposicional (importância vii).

Os fatores que controlam a distribuição dos minerais pesados são complexos e seus efeitos são difíceis de serem entendidos separadamente (Rubey 1933). Segundo Morton \& Hallsworth (1999), a composição mineralógica de um depósito arenoso resulta da interligação complexa entre proveniência (composição mineralógica da área fonte) e fatores que operam durante o ciclo de sedimentação. Assim, a assinatura original de proveniência pode ser obliterada pelos seguintes fatores: intemperismo na área fonte, antes do transporte sedimentar; abrasão mecânica durante o transporte; intemperismo durante a estocagem de sedimentos em uma segunda área fonte; processos hidráulicos durante transporte e deposição final; e diagênese durante o soterramento inicial (eodiagênese) ou tardio (mesodiagênese), seguido de intemperismo no afloramento (telodiagênese). A determinação precisa de proveniência depende do isolamento da influência de cada um destes fatores, através da fixação dos demais (Morton \& Hallsworth 1999).

De acordo com Pettijohn (1941), existe tendência a enriquecimento relativo de minerais ultraestáveis (zircão, turmalina e rutilo) com o aumento de idade dos sedimentos, na medida em que os minerais mais instáveis vão sendo eliminados por dissolução pósdeposicional. Assim, com base na análise comparativa da estabilidade de minerais pesados à dissolução pós-deposicional (Pettijohn 1941) e no uso do conceito de maturidade (Folk 1951) e de seu índice mineralógico clássico, o ZTR (Hubert 1962), seria possível inferir diferenças de idade entre cordões por meio da análise comparativa de suas assembléias de minerais pesados. Desse modo, o estudo de minerais pesados tem sido utilizado para diferenciar areias do Pleistoceno superior e do Holoceno (Giannini 1987, 1989, 1993; De Mio \& Giannini 1997; Giannini et al. 1997b, 2003). É possível também distinguir variações significativas de assembléia mineralógica em feixes de cordões que representam um intervalo de tempo relativamente mais curto, inteiramente contido no Holoceno, como é o caso da llha do Mel, no Estado do Paraná (Angulo et al. 1994, 1996) e da llha Comprida (Guedes 2003; Giannini et al. 2003, 2009), em São Paulo.

A partir dos fatores citados por Pettijohn (1941) e Morton \& Hallsworth (1999), é possível organizar os controles da distribuição de minerais pesados em três categorias principais: proveniência (área fonte), controle hidráulico e dissolução química.

A variação na mineralogia de pesados atribuída ao controle por proveniência deve-se à contibuição de áreas fontes variadas ao longo do processo deposicional; já o controle hidráulico fraciona a abundância relativa dos minerais de diferentes equivalentes hidráulicos (formas e/ou densidades); e o controle por diagênese durante o soterramento diminui a diversidade dos minerais através da atuação da dissolução pós-deposicional. Quando dois 
fatores podem ser isolados (isto é, mantidos constantes), então a variação de minerais pesados reflete a atuação do terceiro fator.

Desse modo, razões entre minerais com comportamento hidráulico e diagenético semelhantes seriam mais favoráveis em refletir características de proveniência e sua variação indicaria mudança de fonte. Os seguintes índices sensíveis à proveniência foram propostos por Morton \& Hallsworth (1999): iAT (apatita-turmalina), iGZ (granada-zircão), iRZ (rutilozircão), iMZ (monazita-zircão) e iCZ (cromoespinélio-zircão. Estes pares de minerais são escolhidos, em cada caso, a partir dos critérios de semelhança de densidade e estabilidade no contexto diagenético estudado.

No que se refere a variação espacial em dada fácies e paleogeografia (mesma paleopraia e, portanto, mesmo alinhamento de cordão, por exemplo), ao se isolar a proveniência, o fator controlador da assembléia de minerais pesados pode ser tanto o hidráulico (forma e densidade) como a estabilidade (Giannini et al. 2004). Para avaliar a influência da estabilidade, convém não se limitar ao exame da variação de índices de maturidade clássicos, como o ZTR. Um dos métodos mais seguros consiste em comparar o comportamento espacial de minerais de equivalentes hidráulicos similares, mas com estabilidades distintas. Analogamente, uma maneira de testar a influência da seleção hidráulica é examinar a variação espacial de minerais de mesma estabilidade, mas com equivalentes hidráulicos distintos (Morton \& Hallsworth 1994, 1999).

De acordo com essa linha de raciocínio, é possível construir outros índices compostos por pares de minerais que possuam duas das três características fundamentais semelhantes e a terceira variável; dessa maneira, o aumento do valor do índice indicaria controle através da característica variável (por exemplo, num par de minerais de mesma fonte e com formas e densidade similares, porém com estabilidades diferentes, a variação no índice indicaria controle por dissolução). Assim, é possível combinar os seguintes pares de minerais (Fig.4.3): índice turmalina-zircão (iTZ), minerais de mesma estabilidade, mas de equivalentes hidráulicos muito diferentes, que, por isso, indicariam controle hidráulico; índice hornblendaturmalina ( $\mathrm{iHT}$ ), minerais de equivalentes hidraúlicos semelhantes, porém de estabilidades químicas contrastantes, (turmalina muito mais estável que hornblenda), e que indicam assim controle por dissolução química; e índice rutilo-zircão (iRZ), dois minerais de densidade, forma e estabilidade semelhantes, e cuja variação é, portanto, indicadora potencial de mudanças de proveniência sedimentar (Guedes et al. 2009, Tanaka et al. 2008, 2009a). 

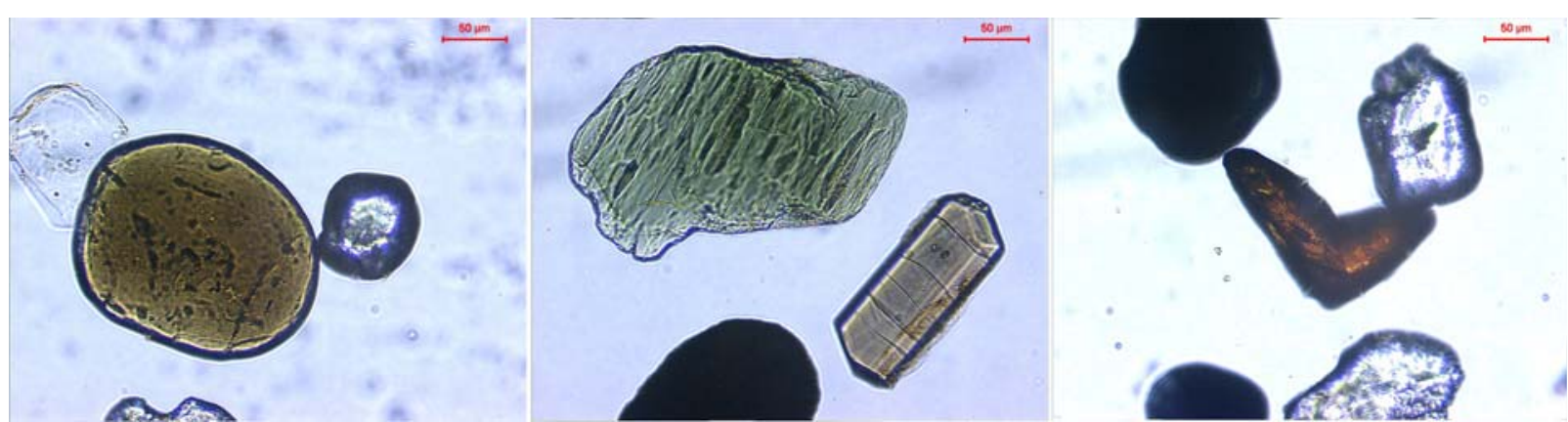

Figura 4.3 - Minerais que compõem índices de controle da composição do depósito por seleção hidráulica (turmalina-zircão, iTZ), proveniência (rutilo-zircão, iRZ) e dissolução (hornblenda-turmalina, $\mathrm{iHT})$.

\subsection{Datação por luminescência oticamente estimulada (LOE)}

O princípio da datação LOE consiste no acúmulo progressivo de cargas elétricas, ao longo do tempo geológico, e a taxa conhecida, no retículo cristalino de minerais do sedimento, como quartzo e feldspato. Este acúmulo deve-se à radiação dos radioisótopos naturais contidos no próprio sedimento, num raio de influência de $30 \mathrm{~cm}$, e à radiação cósmica. As cargas acumuladas no retículo cristalino são liberadas sempre que os minerais são expostos à radiação solar. Após novo soterramento, reinicia-se o acúmulo de cargas no retículo cristalino. Dessa maneira, a datação refere-se ao tempo decorrido desde a última exposição do grão/cristal à radiação solar, o que reflete a idade de soterramento sedimentar. A intensidade da luminescência natural emitida é proporcional à dose de radiação (unidade Gray, $1 \mathrm{~Gy}=1 \mathrm{~J} / \mathrm{kg}$ ) absorvida desde a deposição.

A determinação da idade de soterramento de sedimentos terrígenos pela técnica da luminescência opticamente estimulada (LOE) sofreu grande avanço na última década, com destaque para a formulação do protocolo SAR (Single-Aliquot Regeneration; Duller 1995, Murray \& Wintle 2000, Wintle \& Murray 2006). Este protocolo, baseado entre outros fatores na medição da luminescência de elevado número de alíquotas (24) da mesma amostra, permite a determinação de idades com precisão suficiente para estabelecer a cronologia de eventos deposicionais na escala de décadas a poucos milhões de anos. Uma cronologia baseada em medição instrumental exata é essencial para entender processos geomorfológicos e transporte sedimentar (Madsen \& Muray 2009); por isso, essa ferramenta tem-se demonstrado extremante útil para o entendimento da evolução de sistemas deposicionais quaternários, sendo que é crescente o número de estudos nessa linha de pesquisa (ex. Murray-Wallace et al. 2002, Madsen et al. 2005, Goodwin et al. 2006, Nielsen et al. 2006, Lopez and Rink 2007, Brooke et al. 2008a,b, Sawakuchi et al. 2008, Guedes 2009).

A datação de sedimentos de cordões litorâneos por luminescência, com esta precisão, permite o cálculo de taxas de progradação e a detecção de fases com erosão ou estabilização da linha de costa. Estes resultados são úteis para tentar-se traçar correlação entre estas fases 
de evolução da linha de costa e eventos climáticos ou de NRM de idade conhecida. Além da grande importância para a pesquisa, datações de alta resolução e as novas informações sobre a evolução de terrenos quaternários delas advindas, podem melhorar trabalhos de gerenciamento costeiro.

Dados de idade obtida por LOE ainda são raros para as planícies costeiras sul americanas. Sawakuchi et al. (2008) ressaltam a escassez de estudos cronológicos que lidam com a evolução sedimentar holocênica das barreiras brasileiras numa escala de tempo de alguns milhares a centenas de anos.

\subsection{Eventos climáticos holocênicos de escala milenar}

Além das tendências maiores de variação climática ao longo do Holoceno detectadas através de palinomorfos e de registros de glaciações no continente, estudos mais recentes (principalmente, a partir da década de 1980) baseados em isótopos de testemunhos de gelo, microfósseis depositados em fundo oceânico e espeleotemas reforçam a idéia de variações climáticas em escalas de tempo menor e com freqüência maior (Bond et al. 1997). Variações da composição química de testemunhos de gelo na Groenlândia são interpretadas por O'Brien et al. (1995) como reflexo da dinâmica atmosférica durante o Holoceno, com padrões de variação de escala milenar. Registros do avanço de geleiras no Atlântico Norte (episódios de ice-rafted debris, IRD) e resultados de análise de composição química das geleiras (Bond et al. 1997) indicam mudanças abruptas e pontuais durante o Holoceno, incluindo episódios de queda de temperatura. Durante esses períodos mais frios no hemosfério norte, as geleiras do norte da Islândia avançaram latitudes a sul da Inglaterra (Bond et al. 1997) e a circulação atmosférica sobre a Groenlândia mudou bruscamente (O'Brien et al. 1995).

Desse modo, Bond et al. (1997) definem oito episódios de resfriamento do hemisfério norte no final do Pleistoceno e no Holoceno, com picos em 11100, 10300, 9400, 8100, 5900, 4200, 2800 e 1400 anos AP. Estes eventos seriam manifestações de ciclos climáticos que operam em escala milenar independentemente de estados climáticos glaciais e interglaciais (Bond et al. 1997).

Bond et al. (1997) sugerem que o principal mecanismo responsável pelos ciclos de resfriamento durante a última glaciação seria a circulação termo-halina do oceano Atlântico Norte, com resfriamento da superfície oceânica. Já Bond et al. (2001) ressaltam a dificuldade em identificar mecanismos geradores de tais eventos e os atribuem a variações da atividade solar, interpretação também adotada por Van Geel et al. (2000) e Plunkett \& Swindles (2008).

Registros de eventos climáticos de escala milenar ao longo do Holoceno encontrados na Holanda (Van Geel et al. 1996), Chile (Van Geel et al. 2000), Venezuela (Haug et al. 2001), no mar Arábico ou mar de Omã, entre a península arábica e a Índia (Gupta et al. 
2003), na China (Wang et al. 2005) e na Irlanda (Plunkett \& Swindles 2008), sugerem que os eventos cíclicos do Holoceno identificados por Bond et al. (1997), e desde então conhecidos como Bond events, têm reflexos na dinâmica climática global.

Segundo Bond et al. (1997), o evento climático da Pequena Idade do Gelo (PIG) corresponderia a fase fria mais recente nesta série de ciclos de escala milenar. Na PIG, as temperaturas de verão no hemisfério norte caíram para valores inferiores à média registrada no período entre 1961-1990. O aumento na circulação dos ventos durante a PIG ao longo do altiplano do sul do Peru foi atribuído a mudanças na circulação atmosférica, com anomalias quentes e frias (Thompson et al. 1986). Analogamente, a formação de rupturas de deflação (blowouts), datadas entre $575 \pm 47$ e $172 \pm 18$ anos (LOE), ao longo da planície costeira da llha Comprida, SP, foram atribuídas por Sawakuchi et al. (2008) a aumento da atuação de ventos de sul durante a PIG. Nas áreas de média a alta latitude do hemisfério sul, a PIG corresponderia a um evento de maior umidade, porém possivelmente com intensificação da velocidade dos ventos, como proposto para o sudeste da Patagônia por Moy et al. (2008).

No presente trabalho, discutem-se possíveis registros da influência, na sedimentação regional, do segundo evento de escala milenar (Bond event 2), por volta de 2800 anos AP, (aproximadamente equivalente à época fria da idade do ferro ou Iron Age Cold Epoch, de 900 a $300 \mathrm{aC}$ ), bem como da PIG, por volta de 700 anos AP.

\subsection{Modelos, simulação estocástica e processo markoviano}

A simulação é uma experiência ou ensaio realizado com o auxílio de modelos. Os modelos constituem representações simbólicas de sistemas reais (Churchman 1963), elaboradas pela mente humana a partir da observação e análise da natureza. Constituem assim "uma necessidade primordial de qualquer procedimento científico" (Rosemblueth \& Wiener 1945).

Em geologia sedimentar, o sistema real corresponde comumente a um sistema deposicional, ou seja, "uma unidade estratigráfica física tridimensional geneticamente definida, constituída por fácies sedimentares contíguas relacionadas por processos" (definição de Galloway 1979, baseada em Fisher \& McGowen 1967). A relação entre processos e produtos sedimentares materializada por cada fácies depende da eficiência do transporte e deposição frente às características texturais e mineralógicas dos sedimentos. Esta relação envolve a variabilidade dos processos e do aporte ao longo do tempo. Assim, sistemas deposicionais do mesmo tipo admitem múltiplas possibilidades em termos de características de fácies, governadas por princípios probabilísticos (Anderton 1985). Nesse contexto, a simulação computacional de modelos conceituais aparece como ferramenta adequada. Ela possibilita manipular variáveis do sistema real (por exemplo, a probabilidade 
de ocorrência ou não de fenômenos naturais, como chuva ou ventos) em escalas de tempo e espaço que seriam impraticáveis em modelos físicos.

Antes do advento dos computadores rápidos e de fácil acesso, a escolha de um modelo estocástico para descrever dado fenômeno real implicava a construção de modelo físico adequado à situação (réplica ou modelo-escala) ou a elaboração de modelo formal (conjunto de equações) apropriado para a aplicação de análise matemática. Atualmente, a abordagem preferida é desenvolver um modelo conceitual de maneira mais realista possível e dele derivar um modelo formal, que será então analisado por meio de simulação computacional (Ross 1990). Desse modo, a utilização de computadores facilita a simulação de sistemas através de modelos matemáticos; sua simulação equivale a um experimento virtual, utilizado para gerar dados e testar modelos teóricos (Sawakuchi 2006).

Simulações de um modelo conceitual que relaciona a sedimentação eólica costeira com fatores climáticos (velocidade dos ventos e ocorrência de chuvas) e oceanográficos (aporte sedimentar costeiro, amplitude de maré e nível do mar) para campos de dunas costeiros brasileiros foram realizadas por Sawakuchi (2006). Neste tipo de abordagem, o sistema deposicional é descrito em termos de entradas e saídas de sedimentos, estas condicionadas a variáveis aleatórias. Assim, a sedimentação torna-se um processo de natureza estocástica, ou seja, dependente de uma sucessão de eventos aleatórios, e que pode ser simulada em computadores por meio de geradores de números aleatórios. Através da simulação, pode-se investigar o efeito de perturbações e a interação entre os processos desse sistema (Sawakuchi 2006).

Um processo estocástico é a abstração matemática de um processo empírico cujo desenvolvimento é governado por probabilidades (Doob 1990). Um processo é qualquer função de $x$ em relação a um tempo t que pode ser considerada em um momento instantâneo especifico do estado de um sistema real ou hipotético (Gillespie 1992).

Aplicou-se a simulação estocástica a um dos problemas centrais desta pesquisa: a dinâmica evolutiva das planícies costeiras (fluxos e estoques sedimentares) e o desenvolvimento de dunas sob condicionantes climáticos. As simulações foram realizadas com variáveis aleatórias, de dois modos, um para representar um cenário geral de sedimentação costeira, onde as trocas de sedimentos entre compartimentos foram determinadas por uma matriz de probabilidades sem condicionantes climáticos, e outro para representar o cenário específico de um sistema praia-duna inspirado em exemplo local, onde as trocas de sedimentos foram governadas pela geração de condições climáticas aleatórias segundo uma distribuição de freqüências de eventos como chuva, maré e velocidade do vento.

$\mathrm{Na}$ simulação do cenário geral, foi utilizada uma matriz de probabilidades que representa uma cadeia de Markov. Um processo markoviano pode ser descrito de modo 
abrangente como uma generalização de cálculos comuns para acomodar funções matemáticas que contêm certo tipo de imprevisibilidade ou "aleatoriedade" (Gillespie 1992) e apresenta a propriedade chamada memória markoviana, onde os estados anteriores são irrelevantes para a predição dos estados seguintes, desde que se conheça o estado atual (Howard 1971). A distribuição condicional de probabilidades do sistema para o próximo passo depende somente do estado atual do sistema e não de situações anteriores, ou seja, é impossível prever o exato estado do sistema futuro mas as probabilidades do estado futuro podem ser previstas. Landim (1998) ressalta a grande aplicação das cadeias de Markov para o entendimento dos fenômenos geológicos.

\section{MÉTODOS}

\subsection{Pesquisa bibliográfica}

Executou-se levantamento bibliográfico abrangente acerca dos principais temas envolvidos na pesquisa, com destaque para geologia regional do centro-sul catarinense e modelos de evolução quaternária de planícies de cordões na costa sul-sudeste brasileira. Foi dada ênfase aos seguintes temas: sedimentação costeira, gênese de cordões litorâneos, controles na distribuição de minerais pesados e simulação estocástica.

\subsection{Fotointerpretação}

A distribuição e geometria de feições deposicionais foram delineadas com base na análise estereoscópica de pares aerofotográficos em escala 1:25000 (Cruzeiro do Sul Serviços Aéreos: vôo 1978-1980). Para o lançamento dos elementos fotointerpretados, as imagens foram digitalizadas e georreferênciadas através do software $\mathrm{ESRI}^{\circledR} \operatorname{ArcMap}^{\mathrm{TM}}$ 9.3, seguindo-se a arte-finalização digital através do mesmo programa.

Especial atenção foi dada ao reconhecimento e traçado dos alinhamentos de cordões litorâneos, que constituem uma das características morfológicas marcantes das duas planícies estudadas, com destaque para os vários feixes de cordões curvilíneos de Campos Verdes. Adotou-se para tanto a premissa de que séries de alinhamentos de cordões paralelos, truncados sucessivamente, refletem a evolução progradacional (Angulo 1992, Angulo \& Suguio 1995). Nos casos em que o truncamento não se encontrava aparente devido à cobertura vegetal ou a sobreposição por dunas eólicas, os limites entre feixes foram traçados onde se observavam acunhamento dos feixes e/ou mudanças sutis de curvatura. 
A avaliação quantitativa da densidade de cordões que ocorrem em um determinado setor da planície é controlada pelas características da vegetação presente. O reconhecimento de um cordão em fotos aéreas depende da acentuação ou não obliteração do relevo do substrato pela cobertura vegetal (Angulo 1992, Angulo \& Suguio 1995). A ênfase nos truncamentos entre feixes de cordões, adotada aqui, diminui as incertezas decorrentes da identificação isolada de alinhamentos individuais e favorece uma abordagem mais evolutiva. Esse enfoque é coerente com o estabelecimento de uma sucessão provável de fases no decorrer da sedimentação costeira das áreas em questão e já foi utilizado com bons resultados no litoral paulista por Giannini et al. $(2003,2009)$, Guedes $(2003,2009)$ e Bentz (2004).

\subsection{Atividades de campo}

A coleta de dados in loco ocorreu em duas etapas. A primeira foi realizada em projeto anterior (Tanaka 2007) na área de Campos Verdes e envolveu a descrição de 17 pontos, com coleta de 32 amostras subsuperficiais, e perfuração de sondagem a trado oco. A segunda etapa foi realizada entre os dias 10 e 14 de setembro de 2008, quando foram descritos 13 pontos na planície do Ji e um ponto adicional em Campos Verdes, com a coleta de uma amostra por ponto (Fig.5.1). 


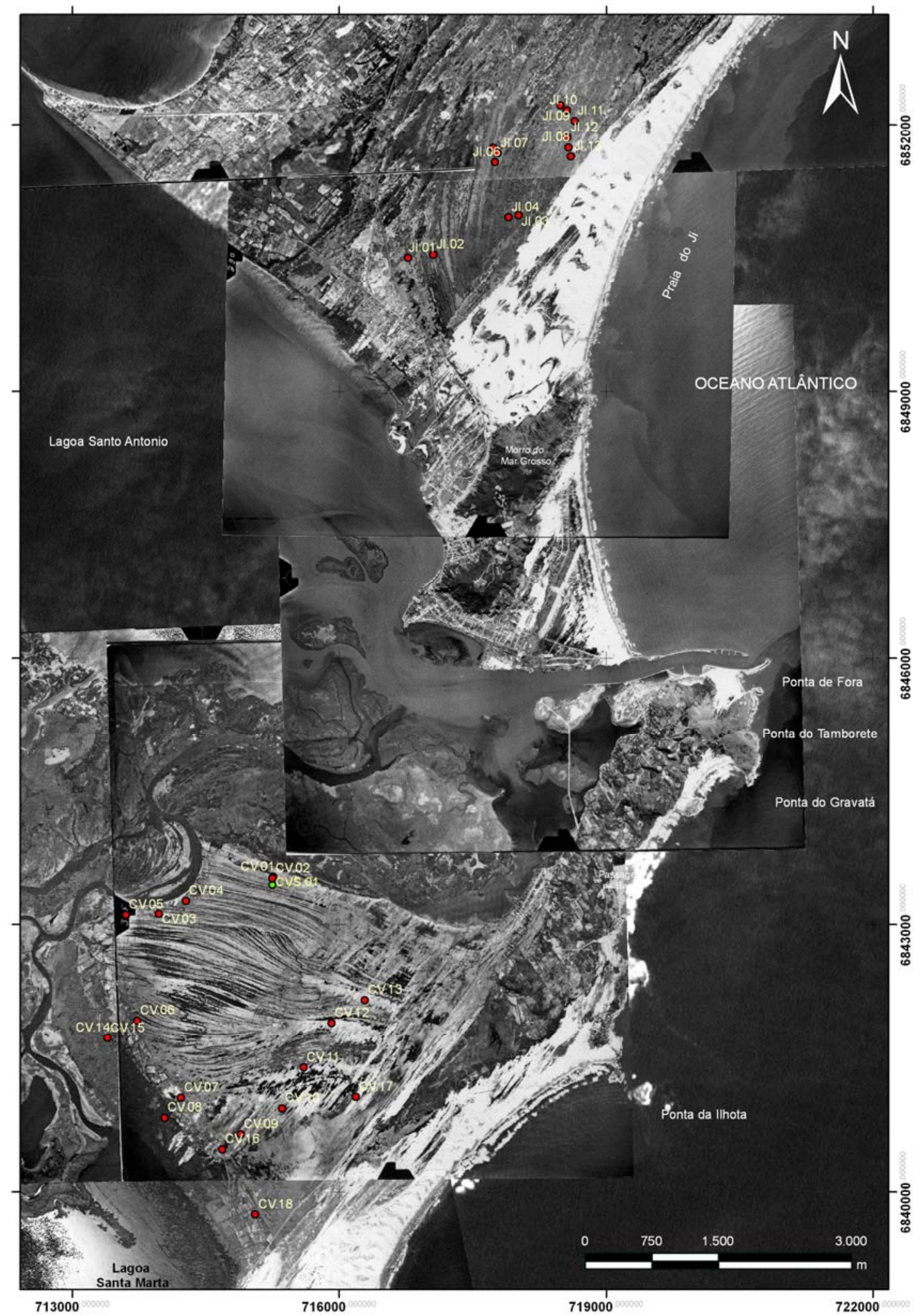

Figura 5.1 - Pontos amostrados em Campos Verdes (CV) e no Ji (JI). O ponto verde (CVS) corresponde a localização de furo de sondagem. Aereofotografias do vôo de 1956 da Cruzeiro do Sul Serviços Aéreos. 
As atividades realizadas no campo seguiram ao roteiro resumido a seguir:

a) Localização do ponto, utilizando sistema de posicionamento geográfico por satélite (GPS - Geographic Positioning System);

b) Abertura de trincheira ou limpeza de exposição natural;

c) Esboço de seções e descrição de fácies;

d) Documentação fotográfica detalhada;

e) Coleta de amostras sedimentológicas e para datação.

Dos trabalhos de campo realizados nas duas planícies, resultou um total, encaminhado para análises laboratoriais sedimentológicas, de 46 amostras obtidas em trincheiras e 13 amostras retiradas em intervalos verticais de $1 \mathrm{~m}$ (a partir da profundidade de $1,5 \mathrm{~m})$ do furo de sondagem a trado motorizado. Para datação por luminescência opticamente estimulada (LOE), foram destinadas 18 amostras.

Os códigos dos pontos de amostragem realizados seguiram o padrão adotado nas áreas costeiras de Santa Catarina, no âmbito de outros estudos do grupo de pesquisa. A sigla inicial baseia-se no município ou região geográfica correspondente (no presente caso, utilizou-se as siglas $\mathrm{CV}$ e $\mathrm{Jl}$ ), acrescida de $\mathrm{S}$ para sondagem motorizada. $\mathrm{O}$ algarismo subsequente à sigla indica a localização do ponto de amostragem, numerada segundo a ordem de coleta.

\subsection{Amostragem}

\subsubsection{Amostras de trincheira}

As amostras rasas foram coletadas subsuperficialmente em trincheiras de 0,5 a $2 \mathrm{~m}$ de altura, abertas manualmente em depósitos sedimentares naturais, tendo em vista a descrição e delimitação de fácies e a amostragem com controle faciológico e/ou estratigráfico. Realizou-se a coleta pontual das amostras de cordões, dunas (lobos deposicionais parabólicos de espessura métrica e depósitos mais delgados de dunas parabólicas) e pontal de retrobarreira lagunar em espaçamentos regulares e em quantidades suficientes para perfazer uma massa entre 1 e $2 \mathrm{~kg}$ por amostra.

\subsubsection{Amostras de sondagem}

As amostras profundas foram coletadas em intervalos de $1 \mathrm{~m}$ a partir da profundidade de $1,5 \mathrm{~m}$ do furo de sondagem a trado oco (STO), cujos dados de coleta são apresentados na Tabela 5.1. O equipamento utilizado nesta técnica de investigação de sub-superfície assemelha-se a um trado espiral de grande porte (cuja haste, pode ultrapassar $8 \mathrm{~m}$ ), operado por equipamento a motor a diesel, adaptado sobre caminhão (Fig.5.2). A coluna amostradora é montada a partir de peças de cilindro oco central encaixadas em estágios (Souza et al. 
1998), onde um barrilete amostrador, portando recipiente (liner) de plástico para coleta, pode ser encaixado (Fig.5.2). Cada liner possui duas tampas, cujas cores preta e vermelha permitem identificar o topo e a base do testemunho. Um martelo hidráulico auxilia na penetração rotativa dos estágios de trado.

Tabela 5.1 - Dado da sondagem STO executada na planície de Campos Verdes.

\begin{tabular}{|c|c|c|c|}
\hline Sigla & Descrição do local & Localização UTM (S/E) & Coluna recuperada \\
\hline CVS.01 & Próximo ao cemitério (norte) & $0715246 / 6843449$ & $14,5 \mathrm{~m}$ \\
\hline
\end{tabular}

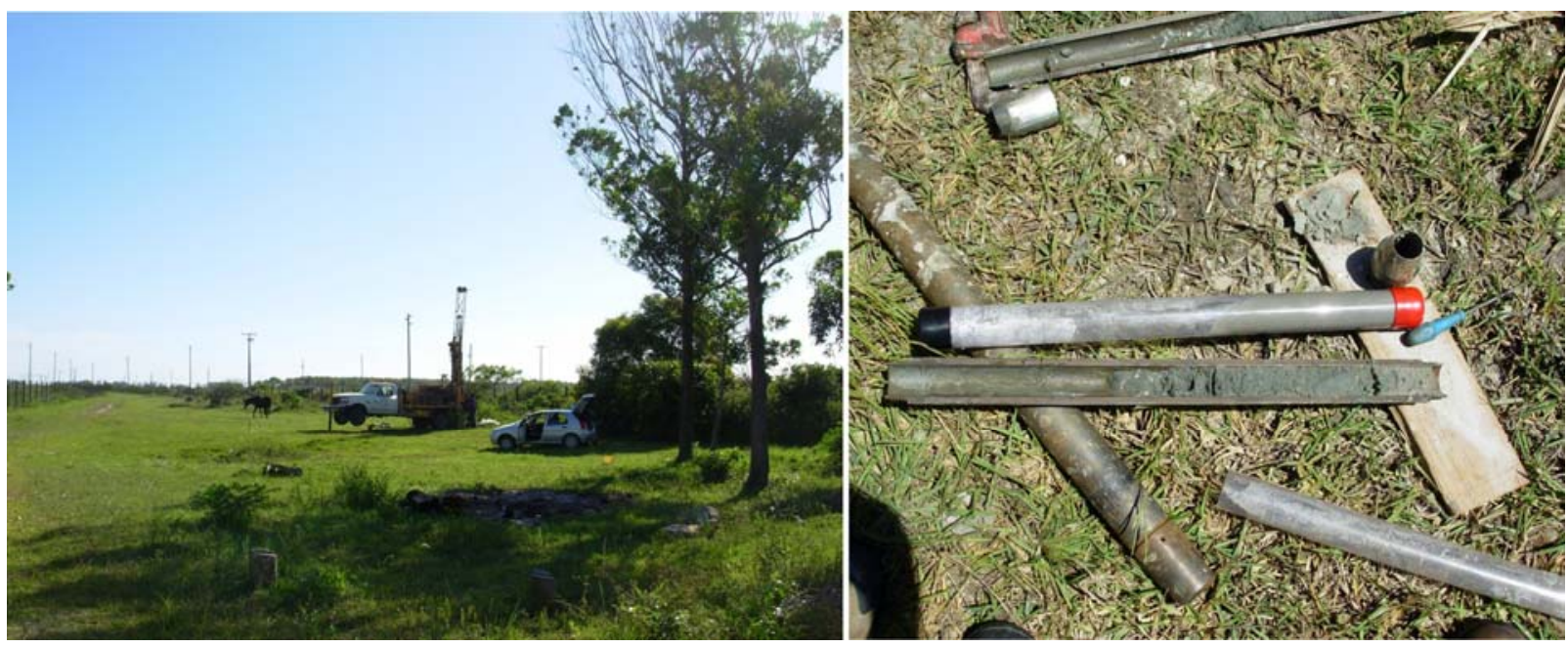

Figura 5.2 - Sondagem a trado oco (STO): equipamento de sondagem, adaptado a caminhão, em operação na planície de Campos Verdes (esquerda); barrilete amostrador de metal e liners plásticos para coleta e condicionamento das amostras (direita).

Para a realização do furo de sondagem, foi contratado serviço de STO junto à empresa especializada. Executaram-se amostragens descontínuas de metro em metro, onde cada liner recuperado, com $4 \mathrm{~cm}$ de diâmetro por $50 \mathrm{~cm}$ de comprimento, contém amostra representativa de seu intervalo amostrado (Fig.5.2).

Entre as dificuldades encontradas, menciona-se o avanço do barrilete amostrador nos intervalos mais arenosos, especialmente os de areia fina abaixo do nível freático. Nesses casos, valeu-se da injeção de água associada a barrilete bipartido. Em algumas operações, estas dificuldades levaram à redução local do intervalo efetivamente amostrado e, mais raramente, à destruição do liner no interior do testemunhador, como ocorrido no intervalo de 5,5 a 6,5 m, o qual não teve recuperação.

Outra limitação da técnica, em parte associada à dificuldade anterior, reside na grande variação de quantidade de sedimento coletado, entre diferentes intervalos de amostragem. 


\subsubsection{Amostras para datação}

As amostras para datação absoluta por LOE foram coletadas com auxílio de tubos de PVC opacos, com cerca de $7 \mathrm{~cm}$ de diâmetro e $30 \mathrm{~cm}$ de comprimento, tanto em depósitos de paleodunas eólicas como em cordões de praia lagunar. Nestes cordões, a coleta foi executada preferencialmente em fácies de areia fina cinza a amarela, idealmente com estratificação plano-paralela visível, estrutura interpretada como indicativa de deposição em leito plano de baixa profundidade, formado por espraiamento de onda. Procurou-se posicionar a amostra no centro de uma zona circular imaginária de cerca de $30 \mathrm{~cm}$ de diâmetro (círculo de influência da radiação da amostra), definida de modo a assegurar a máxima homogeneidade possível de características sedimentológicas.

\subsection{Atividades de laboratório}

A finalidade das análises laboratoriais realizadas foi avaliar a variação espacial de parâmetros sedimentológicos (granulométricos e mineralógicos) nos cordões e nas dunas eólicas, como ferramenta para inferência da morfodinâmica do sistema deposicional costeiro que thes deu origem e para obtenção de critérios adicionais de caracterização faciológica.

As atividades analíticas foram executadas no Laboratório de Sedimentologia do Departamento de Geologia Sedimentar e Ambiental (GSA) do Instituto de Geociências da Universidade de São Paulo (IG-USP).

O primeiro passo foi a pré-preparação das amostras para análise granulométrica convencional (elutriação e peneiramento), cujos produtos foram, em seguida, aproveitados na separação de minerais pesados, separação de minerais magnéticos e confecção de lâminas de minerais pesados não magnéticos. Nos subitens a seguir, são descritas detalhadamente as etapas de análise laboratorial.

\subsubsection{Análise granulométrica por peneiramento}

A análise granulométrica foi realizada em duas fases. A primeira, a elutriação, consistiu na lavagem da amostra para remoção do sal e dos finos (silte e argila), estes em geral de ocorrência subordinada (teor estimado inferior a $20 \%$ em massa). O remanescente de lavagem, depois de seco em estufa, foi submetido à segunda fase, correspondente à análise granulométrica por peneiramento mecânico convencional, em intervalos de 0,5 phi na escala de Wentworth-Krumbein. 


\subsubsection{Elutriação}

O procedimento genérico para a elutriação utiliza-se de uma montagem para produção de fluxo ascendente, de outra montagem para filtragem a vácuo e de béquer de $600 \mathrm{ml}$ para transferência do material entre as duas montagens. A primeira montagem, destinada à elutriação propriamente dita, consiste em um funil liso de $600 \mathrm{ml}$, apoiado em aro-suporte metálico, com haste conectada, através de mangueira flexível, a uma torneira de água corrente. No sistema de filtragem, conecta-se um funil raiado com papel-filtro qualitativo a um frasco kitassato, este por sua vez conectado à tubulação de vácuo. Utiliza-se papel-filtro qualitativo, previamente marcado com o código da amostra em tinta resistente à água e à temperatura da estufa, com forma circular e cerca de $25 \mathrm{~cm}$ de diâmetro. O procedimento é realizado em cinco etapas: a) colocação da amostra, previamente pesada, no funil cheio de água; b) abertura da torneira conectada à haste do funil, com manutenção de fluxo ascendente suficiente para a eliminação de silte e argila em suspensão, até que a água se torne límpida (nas amostras analisadas, esse tempo foi de aproximadamente 5 minutos); c) transferência do material lavado, do funil para o béquer, com ajuda do fluxo de água da torneira; d) transferência do material elutriado para o funil do sistema de filtragem, com auxílio de pisseta; e) filtragem a vácuo; f) secagem do papel filtro com areia elutriada em estufa, a temperatura entre 50 e $60^{\circ} \mathrm{C}$, pelo tempo mínimo aproximado de 12 horas; e g) pesagem da areia elutriada e seca, em balança analítica

\subsubsection{Peneiramento}

Para o peneiramento, foi utilizado o conjunto de base e dez peneiras, empilhadas com malha $(\mathrm{mm})$ crescente de baixo para cima, conforme a Tabela 5.2:

Tabela 5.2 - Lista de peneiras granulométricas utilizadas

\begin{tabular}{|c|c|}
\hline $\begin{array}{c}\text { Fração nominal de } \\
\text { Wentworth (retida) }\end{array}$ & Abertura da malha $(\mathrm{mm})$ \\
\hline areia muito grossa & 1,41 \\
\hline areia muito grossa & 1,00 \\
\hline areia grossa & 0,71 \\
\hline areia grossa & 0,50 \\
\hline areia média & 0,35 \\
\hline areia média & 0,250 \\
\hline areia fina & 0,177 \\
\hline areia fina & 0,125 \\
\hline areia muito fina & 0,088 \\
\hline areia muito fina & 0,062 \\
\hline silte e argila (fundo) & $<0,062$ \\
\hline
\end{tabular}

Na peneira superior, despeja-se a amostra previamente elutriada e seca. Em seguida, o conjunto de peneiras é colocado em vibrador (3600 rpm), onde permanece pelo tempo 
padrão de 15 minutos. O material retido em cada peneira é então recolhido com ajuda de pincel, pesado em balança analítica e arquivado em sacos de papel devidamente identificados. Anotam-se as massas de cada fração de peneiramento em um formulário.

\subsubsection{Análise mineralógica}

A separação de minerais pesados da fração areia muito fina foi realizada pelo método de afundamento em bromofórmio, $\mathrm{CHBr}_{3}\left(\rho=2,85 \mathrm{~g} / \mathrm{cm}^{3}\right)$. Após seca, a fração de grãos afundados foi submetida à separação magnética com imã portátil. Lâminas permanentes foram montadas a partir da imersão dos grãos da fração pesada não-magnética em bálsamo do Canadá. A quantificação de minerais pesados ao microscópio petrográfico seguiu o método de contagem, em linhas aleatórias (ribbon counting: Galehouse 1971, Mange \& Maurer 1992), de pelo menos 100 grãos transparentes não micáceos. Para a obtenção dos índices turmalina-zircão (iTZ= 100x turmalina/turmalina+zircão), hornblenda-turmalina (iHT= 100x hornblenda/ hornblenda+turmalina) e rutilo-zircão (iRZ= 100x rutilo/ rutilo+zircão) contaram-se 200 grãos dos dois minerais envolvidos em cada índice, conforme proposto por Morton \& Hallsworth $(1994,1999)$. Nas amostras de Campos Verdes e na amostra Jl.08, todavia, a contagem do iRZ não perfez 200 grãos devido a baixa freqüência do rutilo. Foi calculada a porcentagem dos índices somatórios de minerais pesados ultraestáveis (iZTR= zircão + turmalina + rutilo) de acordo com a definição de Hubert (1962). Calcularam-se, de modo análogo, as porcentagens dos índices somatórios de minerais metaestáveis (iMET = epídoto + estaurolita + sillimanita + cianita + granada + monazita) e instáveis (ilNS = hornblenda + hiperstênio + augita + dipsídio + tremolita + andaluzita) segundo a classificação de estabilidade de Pettijohn (1957).

\subsubsection{Datação}

Foram datadas pelo método LOE 18 amostras de sedimentos arenosos coletadas em perfis transversais aos feixes de cordões litorâneos e paleodunas eólicas de Campos Verdes e do Ji. As datações foram realizadas no Laboratório de Dosimetria do Departamento de Física da Oklahoma State University (OSU).

A dose natural equivalente é determinada comparando-se o sinal natural de luminescência e o obtido após exposição à radiação produzida no laboratório (dose de resposta). De posse dessas informações, calcula-se a idade da amostra de acordo com a equação 5.1 (Aitken 1985, 1998; Wintle 1997):

$$
\text { Idade }[a]=\frac{\text { Dose equivalente }[\mathrm{Gy}]}{\text { Taxa de dose anual }[\mathrm{Gy} / \mathrm{a}]}
$$


A acumulação de cargas no cristal ocorre em velocidade proporcional à taxa na qual a energia ionizada é por ele absorvida. Essa radiação ionizada deriva-se principalmente do decaimento radioativo do ${ }^{232} \mathrm{Th},{ }^{235} \mathrm{U},{ }^{238} \mathrm{U}$ (e nucleotídeos filhos), ${ }^{40} \mathrm{~K},{ }^{87} \mathrm{Rb}$, e em menor parte, da radiação cósmica. Sendo conhecida a meia-vida dos elementos-filhos, a taxa de dose pode ser determinada a partir da concentração destes elementos na amostra. A dose é calculada através dos fatores de conversão propostos por Adamiec \& Aitken (1998), cujos passos são brevemente descritos a seguir.

A água presente nos poros dos sedimentos absorve parte da radiação. Desse modo, a taxa de dosagem em sedimentos úmidos é menor, o que torna necessário calcular o teor de umidade da amostra, de acordo com a equação 5.2 :

$$
\text { Teor }_{\text {um }}=\frac{\left(m_{u m}-m_{\text {sec }}\right)}{m_{\text {sec }}}
$$

A partir da concentração dos elementos Th $\left({ }^{232} \mathrm{Th}\right.$ em ppm), U (natural em ppm) e K (natural em \%), é possível calcular a contribuição das radiações alfa, beta e gama na taxa de dose, pela equação 5.3:

$$
\dot{D}=\frac{\dot{D}_{\beta, \text { seco }}}{1+1.25 \times T_{u m}}+\frac{\dot{D}_{\gamma, \text { seco }}}{1+1.14 \times T_{u m}}+\dot{D}_{\text {cosm }}=\dot{D}_{\beta, \text { eff }}+\dot{D}_{\beta, \text { eff }}+\dot{D}_{\text {cosm }}
$$

Considerando que quartzo é o principal constituinte mineralógico das amostras (com mais de $80 \%$ de concentração em massa), grãos de quartzo na faixa granulométrica de 120 a $150 \mu \mathrm{m}$ foram separados e preparados sob luz vermelha com tratamento de $\mathrm{H}_{2} \mathrm{O}_{2} 27 \%, \mathrm{HCl}$ $3,75 \%$, HF $40 \%$ por 40 minutos e subsequente separação densimétrica com solução de politungstato de sódio (às densidades de $2,75 \mathrm{~g} / \mathrm{cm}^{3}$ e 2,62 g/ $/ \mathrm{cm}^{3}$ ).

A fração de radiação devida ao efeito cósmico depende da posição geográfica do local de coleta da amostra e é calculada como proposto por Barbouti \& Rastin (1983) e Prescott \& Stephan (1982). Para determinação das doses de radiação acumulada, foi utilizado o protocolo SAR segundo a proposta de Murray \& Wintle (2000), em alíquotas de grãos de quartzo na fração areia. O procedimento estabelecido neste protocolo encontra-se descrito na Quadro 5.1.

As medidas de luminescência e a irradiação das alíquotas foram realizadas em equipamento Risø DA-15 TL/OSL system, equipado com fontes de radiação alfa e beta. Taxas de dose de radiação foram determinadas por espectrometria gama, por meio de detector de germânio puro (HPGe).

Discussão detalhada sobre os métodos de datação LOE pode ser encontrada em Aitken (1998) e Bøtter-Jensen et al. (2003), e na revisão apresentada por Lian \& Roberts (2006). 
Quadro 5.1 - Passo a passo do procedimento SAR, usado para determinar a dose equivalente (adaptado de Sawakuchi et al. 2008).

\begin{tabular}{|c|c|}
\hline Passo & Descrição \\
\hline 1 & Aplicar dose $D_{n}$ \\
\hline 2 & Pré-aquecer a temperatura de $220^{\circ} \mathrm{C}$ por $10 \mathrm{~s}$ para remover sinais instáveis \\
\hline 3 & Estimular com LEDs azuis por 100 s a $125^{\circ} \mathrm{C}$ e medir sinal Ln de LOE \\
\hline 4 & Aplicar teste de dose, $15-20 \%$ de dose esperada \\
\hline 5 & Pré-aquecer a $160^{\circ} \mathrm{C}$, para remover sinais instáveis \\
\hline 6 & Estimular com LEDs azuis por 100 s a $125^{\circ} \mathrm{C}$ e medir sinal Ln de LOE \\
\hline 7 & Estimular com LEDs azuis por 40 s a $260^{\circ} \mathrm{C}$, para reduzir recuperação \\
\hline 8 & Retornar ao passo 1 , para aplicar dose $D_{n+1}$ \\
\hline \multicolumn{2}{|c|}{$\begin{array}{l}D_{n} \text { : dose enésima; } L_{n} \text { : luminescência enésima } \\
\text { Ciclo 1: } D_{1}=0 \text {. } \\
\text { Ciclo 2-5: dose-resposta com regeneração de doses } D_{2}, D_{3}, D_{4}, D_{5} \text {. } \\
\text { Ciclo 6-7: repetir doses com } D_{3}<D_{6}<D_{4} \text { e } D_{7}=D_{2} \text {. } \\
\text { Ciclo 8: } D_{8}=0 \text {. } \\
\text { Ciclo 9: dose } D_{9}=D_{6} \text { com adicional estímulo IR a } 60^{\circ} \mathrm{C} \text { por } 100 \text { s entre }\end{array}$} \\
\hline
\end{tabular}

\subsection{Tratamento de dados}

\subsubsection{Informação de campo}

Informações de campo foram anotadas em cadernetas, posteriormente registradas e compiladas em planilha eletrônica Microsoft ${ }^{\circledR}$ Office Excel, sendo as seções digitalizadas em software CorelDraw ${ }^{\circledR}$. A documentação fotográfica foi realizada com câmera digital, com a finalidade de ilustrar os locais de amostragem e registrar as geometrias externa e interna dos depósitos sedimentares, servindo assim como ferramenta auxiliar na descrição e delimitação de fácies.

\subsubsection{Resultados analíticos laboratoriais}

O tratamento dos resultados brutos de distribuição em massa da granulometria incluiu contabilização do percentual de cada classe granulométrica, com exclusão dos bioclastos, e cálculo das estatísticas descritivas (diâmetro médio, desvio padrão e assimetria) da distribuição granulométrica, agrupada em classes de 0,5 phi, pelo método analítico dos momentos de Pearson. Os resultados assim obtidos foram lançados em gráficos em função da distância (transversal e longitudinal aos feixes de cordões litorâneos), com o intuito de verificar possíveis padrões ou tendências de variação espacial e desse modo interpretar o rumo de crescimento progradacional e a paleoderiva litorânea nas planícies em estudo. 
Para refinar o teste estatístico dos rumos de retrabalhamento ou transporte inferidos, utilizou-se o software GSTAST (Grain Size Trend Analysis with Significant Test), desenvolvido por Chang et al. (2001). Este programa utiliza os padrões indicadores de transporte sedimentar de McLaren \& Bowles (1985) combinados com o conceito de rede de transportes de Gao \& Collins (1992), onde cada ponto amostrado é comparado individualmente a todos os seus vizinhos, dentro de uma distância característica, escolhida pelo usuário. A cada vetor de transporte aceito pela regra de McLaren \& Bowles (1985), que se projeta de determinada estação rumo estação vizinha, atribui-se um "comprimento" de valor 1, adimensional (versor). O vetor resultante é calculado para estações que possuem dois ou mais vetores, e portanto possuirá rumo e valor escalar determinado por uma soma vetorial. A consistência da rede de vetores é avaliada a cada iteração de troca aleatória nos valores originais entre as estações. Na aplicação do programa, assumiram-se valores de 0,05 para o nível de significância, 1500 m para distância crítica e 100 para número de iterações (número de iterações recomendado pelos criadores do programa, para intervalos de confiança acima de 50\%).

As retas de regressão e os valores de coeficiente de determinação $\left(r^{2}\right)$ foram obtidos por meio do software Microsoft ${ }^{\circledR}$ Excel. O critério estatístico utilizado para avaliar os resultados de $r$ foi o nível de significância $(\alpha)$ ou erro I, para rejeição de hipótese nula (aceitação da correlação), de acordo com o teste unicaudal t de Student. Este nível mede a probabilidade de a correlação indicada ser inexistente. Para o teste, admitiram-se resultados de correlação linear com nível a menor ou igual a 0,4.

Lançaram-se três índices de maturidade (iZTR, iMET e iINS) mais três índices de avaliação de fator controlador da mineralogia (ou, simplesmente, "índices de controle": iTZ, iHT e iRZ) em gráficos de freqüência versus distância, em perfis transversal (para amostras de cordão e de duna eólica) e longitudinal (para amostras de cordão) ao feixe de alinhamentos, bem como em mapas de interpolação. Os gráficos foram construídos nos softwares Microsoft ${ }^{\circledR}$ Excel e mapas de interpolação foram obtidos com o software $E S R I^{\circledR}{ }^{A} C M a p^{T M}$ 9.3. Para a confecção de gráficos de frequência de índices de minerais pesados versus idade, utilizou-se o software Origin ${ }^{\circledR}$ Pro8 SRO.

Testes estatísticos como comparações entre médias e desvios padrões de cada agrupamento de amostras foram aplicados aos resultados sedimentológicos e mineralógicos, utilizando o software Minitab ${ }^{\circledR}$ 15.1.30.0. Os dados composicionais (índices de maturidade) foram transformados em sua razão log central (centered-log-ratio, clr), conforme proposto por Aitchison (1982); para os dados submetidos a essa transformção, foi acrescentado o prefixo clr ao longo do texto. Os resultados assim obtidos foram lançados em diagramas de caixa (boxplots) e em matrizes de dispersão (scatter plots), para verificar possíveis padrões ou tendências características dos sedimentos de cada planície ou de cada fácies. A análise de 
componentes principais foi realizada para avaliar qual é a influência que conjuntos de variáveis têm sobre cada amostra. Este recurso permite ponderar a importância de cada variável sobre a distribuição dos pontos lançados em gráficos da componente principal 1 (PC1) pela componente principal 2 (PC2) e, desse modo, separar grupos de amostras por critérios de similaridade mais rigorosos.

\subsection{Simulação}

O volume de sedimento transportado por unidade de tempo (fluxo), o volume de sedimentos contidos nos reservatórios (estoque, no caso representado pela praia e pelas dunas eólicas) e a posição da linha de costa foram os dados de interesse das simulações. As datações serviram para estimar o intervalo de tempo e as taxas de progradação que se desejaram simular, para permitir comparações entre os dados simulados e os dados reais. Esta simulação serviu-se das linguagens Python e Vensim.

Para estimar os volumes dos compartimentos fisiográficos (duna, praia, continente e mar) considerou-se a aproximação de cada compartimento a uma forma geométrica (ex. pirâmide, prisma) delimitada em relação ao tamanho da área de estudo. As medidas da área da base e altura foram realizadas a partir das fotos aéreas, com uso do software ESRI ${ }^{\circledR} \operatorname{ArCMap}^{T M}$ 9.3.

\subsubsection{Simulação em Python}

Segundo Lutz \& Ascher (2007), Python é uma linguagem de programação popular orientada a objetos, de código-fonte aberto, e utilizada em uma variedade de domínios, tanto para programas independentes como para aplicações de script (entende-se por script, um arquivo de nível superior mais simples e por programa, um aplicativo de vários arquivos sofisticados). Sua atratividade provém da portabilidade, versatilidade e facilidade de uso. Geralmente, um programa em Python consiste em vários arquivos de texto que contêm instruções de linguagem, sendo estruturado com um arquivo de nível superior principal, mais arquivos complementares opcionais, conhecidos como módulos (Lutz \& Ascher 2007). arquivo de nível superior contém o fluxo de controle principal do programa (arquivo executado para rodar o aplicativo) e os arquivos de módulo são bibliotecas de ferramentas usadas para reunir componentes utilizados pelo arquivo superior (Lutz \& Ascher 2007).

No modelo estudado, elaborado pelo Msc. Hilton Garcia Fernandes (Laboratório de Sistemas Integráveis, Escola Politécnica, Universidade de São Paulo), o arquivo de nível superior principal, denominado mcmc.py, é acompanhado de quatro módulos. O primeiro 
módulo, chamado sys.py, pertence ao ambiente do Python e é usado para acessar características do sistema operacional; o segundo módulo, chamado Markov_chain.py, é a implementação simplificada da simulação pela cadeia de Markov; o terceiro módulo, o Sedimentation_place.py, implementa uma unidade de sedimentação (um compartimento geológico/geomorfológico). Este módulo controla a quantidade de sedimento que entra e sai de cada unidade de sedimentação ou compartimento, individualmente; já o quarto módulo, Sedimentation_system.py, utiliza os outros três módulos para controlar as trocas entre as unidades de sedimentação, ou seja, um sistema onde há trocas de sedimentos entre as unidades de sedimentação ou compartimentos. A troca de sedimentos é governada por fluxos que ocorrem de acordo com uma matriz de probabilidades (cadeia de Markov), onde as linhas fornecem sedimentos de um compartimento para outro e as colunas recebem sedimentos (Fig. 5.3).

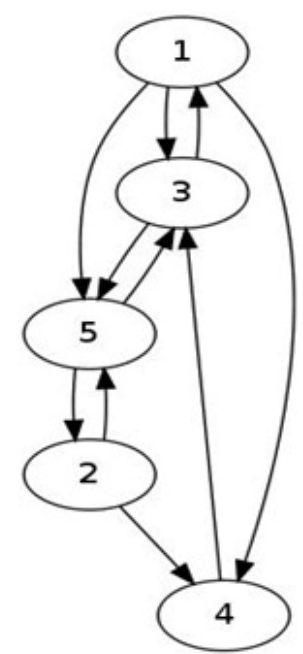

\begin{tabular}{|c|c|c|c|c|c|}
\hline & 1 & 2 & 3 & 4 & 5 \\
\hline 1 & 0 & 0 & 0,1 & 0,5 & 0,4 \\
\hline 2 & 0 & 0 & 0 & 0,3 & 0,7 \\
\hline 3 & 0,4 & 0 & 0 & 0 & 0,6 \\
\hline 4 & 0 & 0 & 1,0 & 0 & 0 \\
\hline 5 & 0 & 0,8 & 0,2 & 0 & 0 \\
\hline
\end{tabular}

$$
\begin{aligned}
& M=\left(\begin{array}{ccc}
a_{11} & \ldots & a_{1 j} \\
\vdots & \ddots & \vdots \\
a_{i 1} & \cdots & a_{i j}
\end{array}\right) \\
& i \longrightarrow j
\end{aligned}
$$

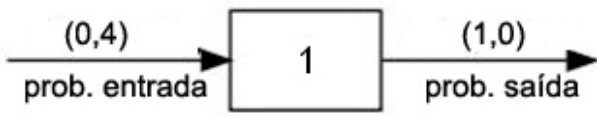

Figura 5.3 - Representação dos fluxos (setas) entre compartimentos (caixas). Os valores de probabilidade de haver troca compõem uma matriz que pode ser representada em forma de tabela de probabilidades. Em termos gerais, i fornece para j.

As setas indicam a possibilidade de haver trocas, atribuída por valores entre 0 e 1 . Especificamente, para o modelo apresentado, os números 1, 2, 3, 4 e 5 correspondem a diferentes compartimentos, continente, praia, campo de dunas 1 (Cd1), campo de dunas 2 (Cd2) e mar, sendo que cada compartimento também é capaz de reter sedimentos. Cd1 e $\mathrm{Cd} 2$ podem ser considerados tanto campos de dunas paralelos ao longo da costa como sucessivos, transversalmente à costa; o que diferencia os dois casos é a probabilidade de fluxo de sedimentos, associado a ocorrência de trocas com os outros compartimentos. No caso estudado, foi considerado um único campo de dunas.

Dessa maneira, é possível desativar qualquer compartimento, por exemplo o campo de dunas 2 que, por não ocorrer no caso estudado, foi de fato desativado. Para isso, foi necessário associar a probabilidade 1 na linha 3 e na coluna 3 (retenção total de sedimentos, sem ocorrência de troca com os demais compartimentos). 
As informações necessárias para rodar a simulação são: estoque inicial, estoque mínimo (admitido por dada unidade de sedimentação), estoque máximo e fluxo, os quais podem ser fornecidos em unidades flexíveis, isto é, à escolha do usuário.

Para o desenvolvimento dos algoritmos da simulação, utilizou-se o software IDLE 2.6.4. Os dados quantitativos foram analisados nos softwares Microsoft ${ }^{\circledR}$ Excel e Origin ${ }^{\circledR}$ Pro8 SRO.

\subsubsection{Simulação em Vensim}

Para o desenvolvimento da simulação do sistema praia-duna com condicionantes climáticos e análise dos dados quantitativos, utilizou-se o software Vensim ${ }^{\circledR}$ PLE 5.9e. Esse software possibilita a realização de um comando de simulação, a qualquer momento em que uma constante ou valores de tabela sejam modificados, sem que seja necessário reiniciar a simulação com os novos valores determinados a cada momento inicial. Isso é feito a partir da ferramenta synthesim, semelhante a um jogo onde é possível mudar valores e ver simultaneamente o resultado.

Vensim é uma linguagem de simulação aplicada no software de modelagem visual de mesmo nome desenvolvidos pela Ventana Systems, Inc. (Harvard, Massachusetts). Essa ferramenta possibilita o desenvolvimento, documentação, simulação e análise de modelos de sistemas dinâmicos e foi delineada para tornar mais fácil o aprendizado da dinâmica de sistemas. Os modelos de simulação são construídos a partir de diagramas causais ou diagramas de fluxo (Sterman 2000).

O sistema praia-duna concebido testa a ocorrência ou ausência de transporte eólico, que depende de uma sucessão de eventos mais básicos ligados a variáveis como chuva, maré e velocidade dos ventos. Para isso, as variáveis climáticas de precipitação $(\mathrm{mm})$ e velocidade dos ventos $(\mathrm{m} / \mathrm{s})$ foram geradas a partir de uma distribuição aleatória baseada em dados do INMET obtidos na estação de Torres (RS), no intervalo entre 1961 e 2009 e entre 1970 e 1982, respectivamente. O intervalo de tempo considerado para os dados coletados de velocidade de ventos é mais restrito que o de precipitação, pois não foram disponibilizados dados contínuos para intervalos de tempo maiores. O uso de dados da estação de Torres (RS), situada centenas de quilômetros a sul da área de estudo, justica-se pelo fato de o registro da estação de Laguna, SC, apresentar grandes lacunas (segundo a EPAGRI, o CLIMERH e o INMET, a estação de Laguna funcionou de janeiro de 1925 a agosto de 1986, sendo que os dados de 1928, 1936, 1965, 1966, 1967, 1970, 1971, 1974, 1975, 1980, 1984 e 1986 estão incompletos).

Para simular períodos chuvosos, foram considerados os dados dos meses de janeiro, fevereiro e março (JFM). Épocas secas foram simuladas a partir de dados dos meses de 
junho, julho e agosto (JJA). Já um período de pluviosidade intermediária foi simulado através dos valores de agosto, setembro e outubro (ASO).

A maré apresenta uma ou duas variações cíclicas diárias (diurna ou semi-diurna), o deslocamento vertical podendo ser descrito por uma função do tipo seno (Sawakuchi 2006). Para simplificar a simulação, optou-se por considerar uma distribuição normal para a variação de maré, construída com base nos dados da tábua de maré do ano de 2008 do porto de Imbituba. A geração de valores está atrelada ao passo escolhido para simulação (time step), de modo que se procurou obter uma variação com dois máximos e dois mínimos diários.

\section{APRESENTAÇÃO E DISCUSSÃO DOS RESULTADOS}

\subsection{Aerofotointerpretação}

Através da identificação de truncamentos de alinhamentos, foram delimitados 14 feixes de cordões litorâneos em Campos Verdes, numerados em ordem crescente de sul para norte, e cinco conjuntos de alinhamentos de cordões concordantes no Ji, numerados em ordem crescente de oeste para leste (Fig.6.1). 


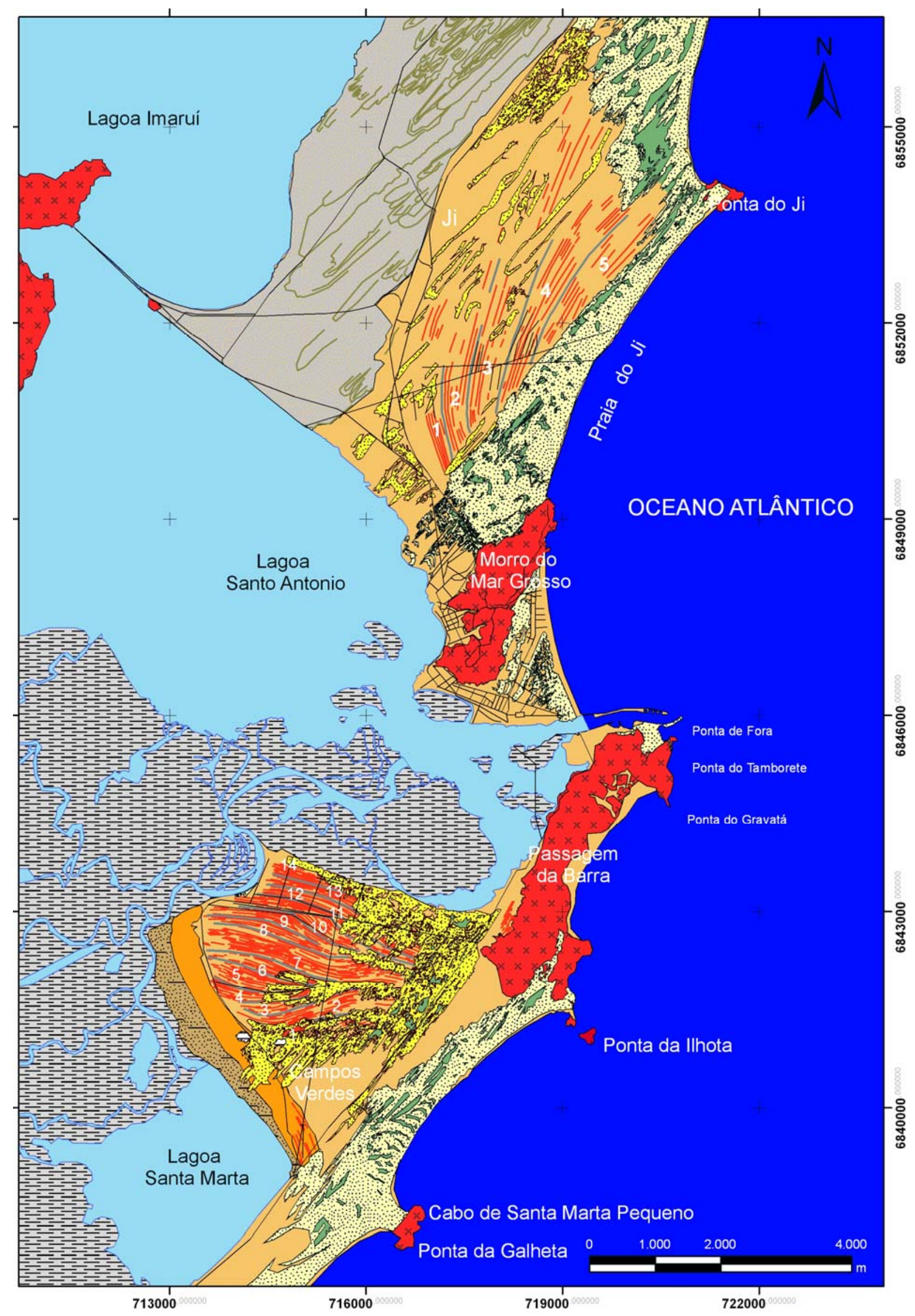

Figura 6.1 - Fotointerpretação da área em estudo, com destaque para as séries de cordões litorâneos sucessivas, numeradas de 1 a 14 em Campos Verdes e de 1 a 5 no Ji. 
Em Campos Verdes (Fig.6.2), os feixes de cordões apresentam forma externa em planta ora lenticular, ora curvilínea com limites subparalelos. Internamente, a forma curvilínea dos cordões comparece em todos eles. O feixe 1 apresenta-se encoberto por vegetação e dunas, sendo que esta vegetação representa o limite sul do feixe 2 . Os feixes 2 e 3 são bastante curvilíneos e com orientação acentuadamente distinta dos demais. Enquanto a orientação dominante dos feixes 4 a 14 varia entre NW e E-W, os feixes 2 e 3 apresentam-se orientados preferencialmente segundo NE.

O truncamento entre os feixes 6,7 e 8 é tênue e marca uma geometria geometria côncavo-convexa (hummocky) em planta, com o conjunto de feixes 9, 10 e 11. Estes apresentam larguras semelhantes e acunhamento a leste, onde são encobertos por dunas eólicas.

Os feixes 12, 13 e 14, apesar de bastante encobertos a leste pelos depósitos eólicos, aparentam ser constituídos por alinhamentos mais retilíneos que os demais.

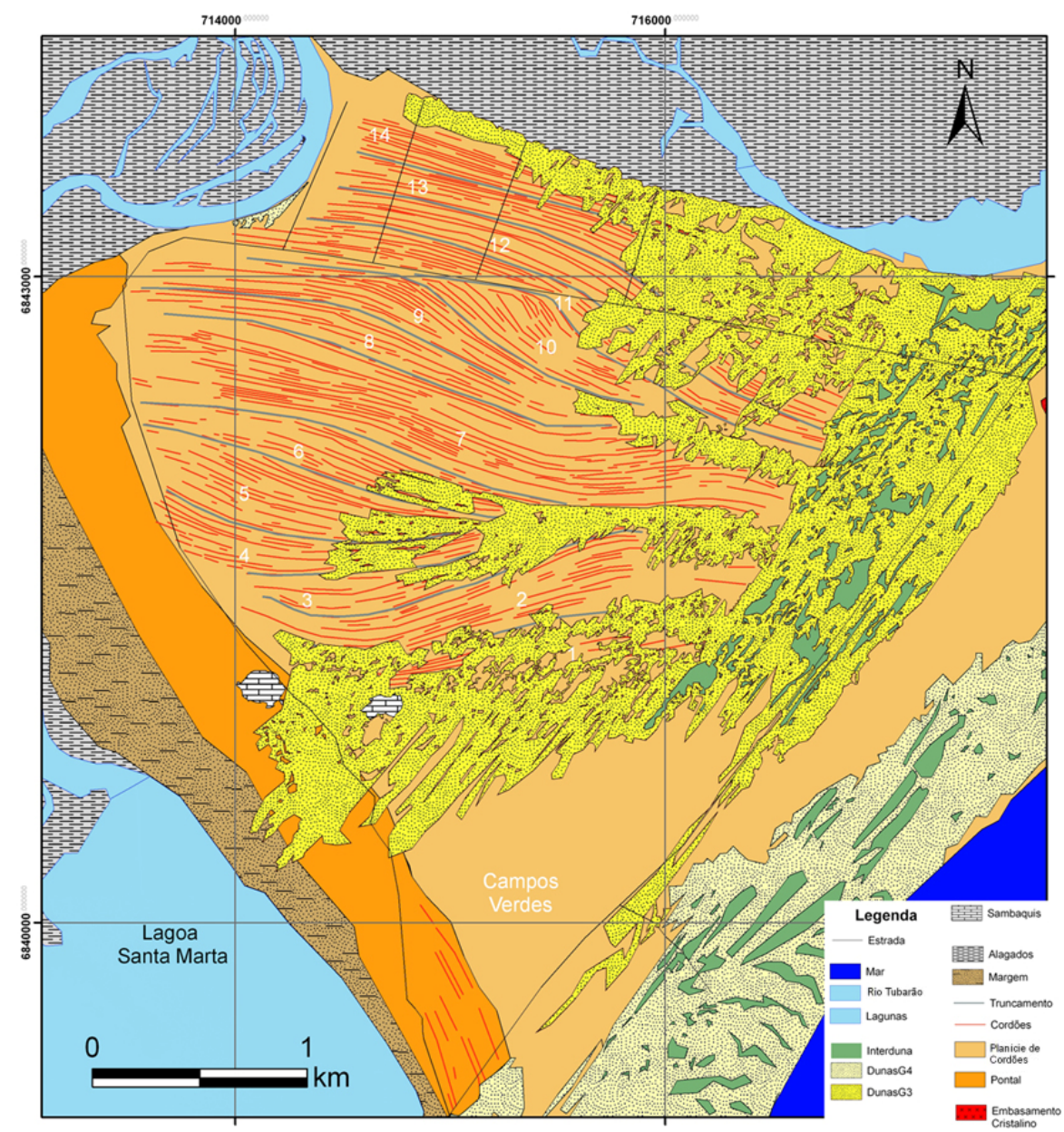

Figura 6.2 - Feixes de alinhamentos de cordões de Campos Verdes, delimitados por truncamentos delineados em fotointerpretação. Numeração ordenada de sul para norte. 
No Ji (Fig.6.3), todos os feixes de cordões apresentam deflexão na sua orientação, ligada à orientação e/ou posição das áreas de ancoramento dos sedimentos costeiros holocênicos. Os conjuntos 1 e 2 são curvilíneos e sua orientação varia de NW, a sul, para $\mathrm{NE}$, a norte; essa variação ocorre devido ao ancoramento dos cordões tanto nas paleodunas parabólicas da geração 2, a oeste, quanto no morro do Mar Grosso (efeito tômbolo), a sul. Os feixes 3, 4 e 5 são ligeiramente mais retilíneos, com direção geral dominante passando de NNE (3) para NE (4 e 5).

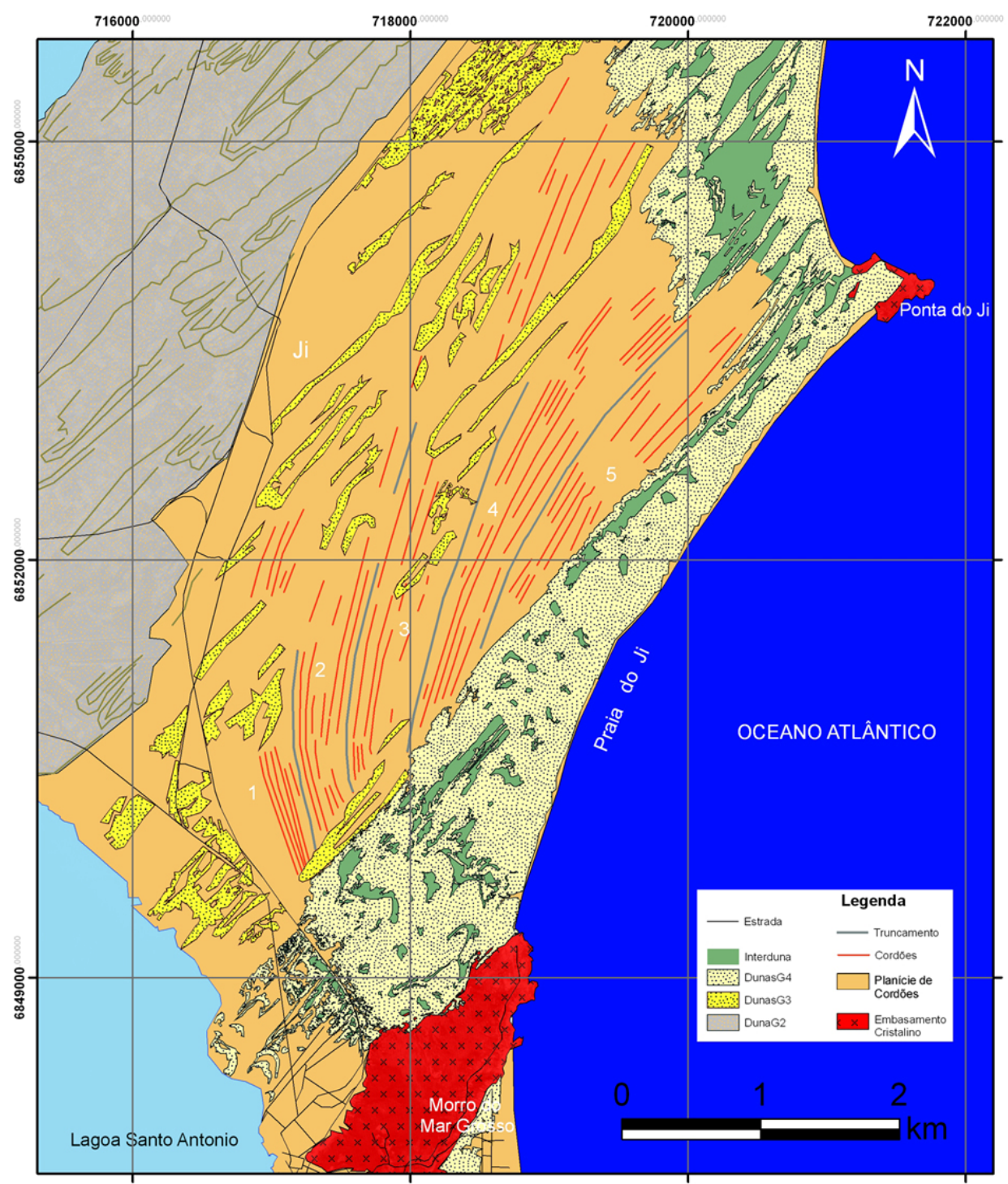

Figura 6.3 - Feixes de cordões litorâneos do $\mathrm{Ji}$, delimitados por truncamentos delineados em fotointerpretação. Numeração ordenada de oeste para leste.

A principal diferença da planície de Campos Verdes em relação a do Ji, quanto ao padrão geométrico de cordões, é o truncamento mais acentuado entre os feixes, o que gera geometria hummocky em planta. Essa geometria é decorrente da maior variação na orientação dos cordões de Campos Verdes, seja no espaço (ao longo de um mesmo cordão) seja no tempo (entre feixes sucessivos); outra diferença é a orientação geral dos 
alinhamentos em relação à linha de costa (de mar aberto) atual: transversal, em Campos Verdes, e, subparalela, no Ji.

\subsection{Granulometria}

\subsubsection{Descrição do registro de sondagem de Campos Verdes}

Durante a perfuração por STO, coletaram-se 14 amostras, em intervalos de $1 \mathrm{~m}$ a partir da profundidade de $1,5 \mathrm{~m}$, cujas descrições preliminares de bancada e distribuição granulométrica se encontram ilustradas na Figura 6.4.

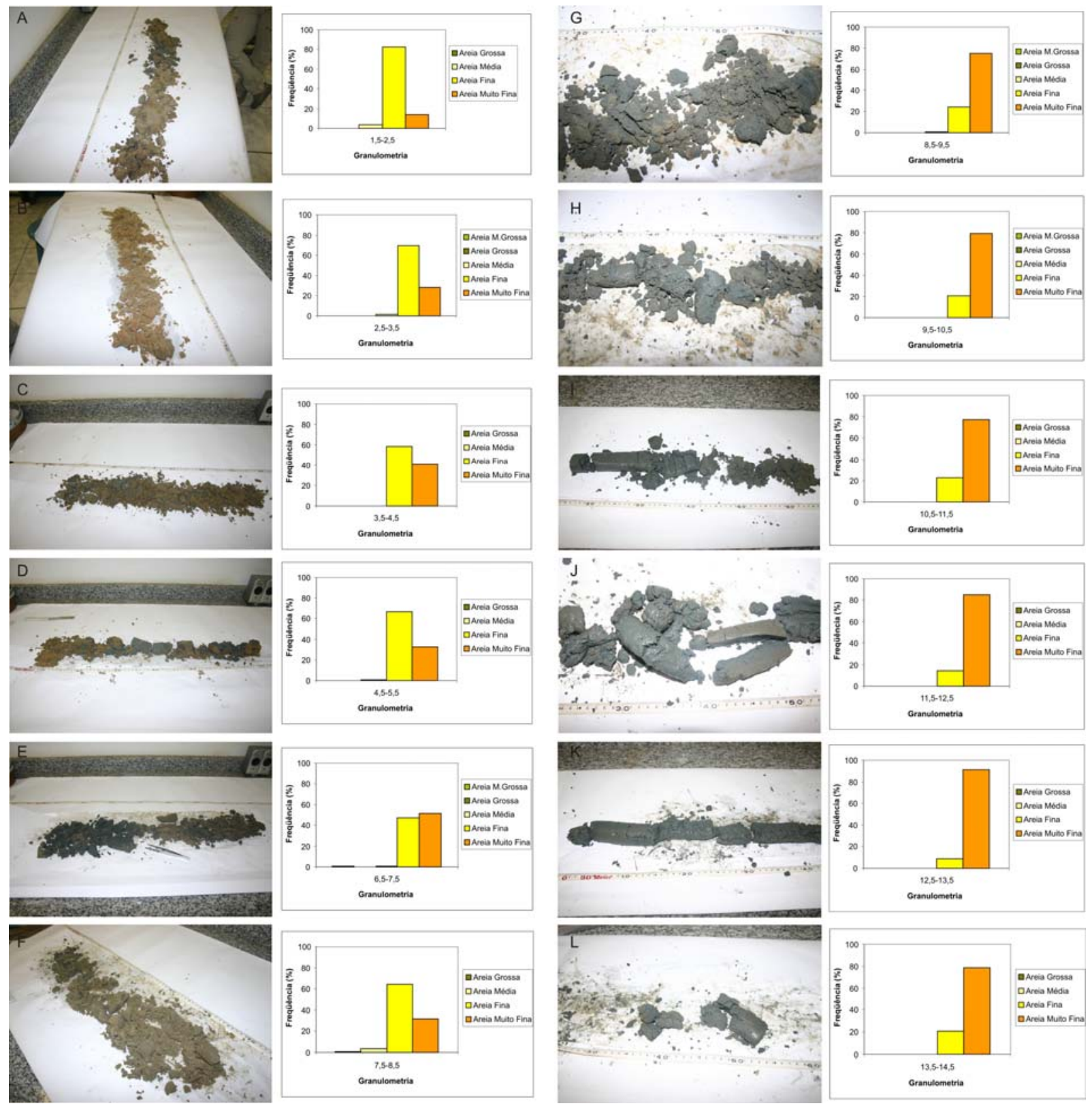

Figura 6.4 - Aspecto das amostras de sondagem a trado oco de Campos Verdes e distribuição de freqüências dos intervalos granulométricos. A) Intervalo de 1,5 a 2,5m. B) Intervalo de 2,5 a 3,5m. C) Intervalo de 3,5 a $4,5 \mathrm{~m}$. D) Intervalo de 4,5 a $5,5 \mathrm{~m}$. E) Intervalo de 6,5 a $7,5 \mathrm{~m}$. F) Intervalo de 7,5 a $8,5 \mathrm{~m}$. G) Intervalo de 8,5 a $9,5 \mathrm{~m}$. H) Intervalo de 9,5 a $10,5 \mathrm{~m}$. I) Intervalo de 10,5 a $11,5 \mathrm{~m}$. J) Intervalo de 11,5 a $12,5 \mathrm{~m}$. 
O intervalo de 1,5 a 5,5m é constituído por areia fina a muito fina de cor cinza amarelado, com presença de raízes na porção superior (1,5 a 2,5m). Na profundidade entre 5,5 e 6,5m, devido a problemas de equipamento, a recuperação de amostra foi muito baixa, menor que o necessário para análise granulométrica. Apesar disso, foi possível observar em campo que se trata de areia muito fina lamosa, com bioclastos fragmentados. Entre 6,5 e $8,5 \mathrm{~m}$ de profundidade, encontra-se areia fina a muito fina cinza com bioclastos inteiros e fragmentados, muito raros (concentração estimada em volume menor que 5\%). Nas profundidades de 8,5 a 10,5m, observa-se afinamento granulométrico com predominância de areia muito fina e ocorrência de areia argilosa cinza com bioclastos fragmentados, raros (concentração estimada em volume menor que $2 \%$ ), até a profundidade de $9,5 \mathrm{~m}$. O intervalo de 10,5 a 13,5m é constituído por areia muito fina a areia argilosa cinza escuro. De 13,5 a $14,5 \mathrm{~m}$, observa-se novamente a ocorrência de raros bioclastos fragmentados (concentração em volume menor que $5 \%$ ).

Com base nesta variação observada de granulometria, constituição e cor, a coluna sedimentar atravessada pela STO foi sub-dividida em dois intervalos principais. O intervalo inferior, entre $14,5 \mathrm{~m}$ e $8,5 \mathrm{~m}$ de profundidade, caracteriza-se por areia lamosa, cinza escuro, sem estrutura aparente, com bioclastos fragmentados e dispersos em proporções menores que $5 \%$. O intervalo superior (de $8,5 \mathrm{~m}$ até a superfície) corresponde a areia fina a muito fina, cinza amarelado, sem estrutura aparente e com presença mais rara de bioclastos fragmentados (somente no intervalo entre 5,5 e $8,5 \mathrm{~m}$ ).

O intervalo inferior foi interpretado como compreendendo fácies de águas mais profundas, depositada freqüentemente abaixo do nível de base de ação de ondas e correntes, daí a maior presença de lama. A cor mais escura é sugestiva de menor oxidação da matéria orgânica. O intervalo superior seria composto por fácies paleolagunares de águas mais rasas e condições deposicionais mais oxidantes.

A passagem, na STO, de areia lamosa para areia fina caracteriza registro regressivo em escala mais ampla: o intervalo inferior corresponderia à fase de inundação, formando uma baía e depois uma baía-laguna; e o superior seria o registro vertical das clinoformas progradantes, formadas sob NRM ligeiramente declinante (cerca de $2 \mathrm{~m}$ em aproximadamente 5000 anos, segundo Angulo et al. 1999), e que, em superfície, formam os cordões litorâneos. Portanto, o intervalo inferior também teria empilhamento regressivo, a exemplo da sucessão amostrada como todo. Já o intervalo inferior pode ser pelo menos em parte transgressivo, mas a análise desta possibilidade depende de estudos futuros mais detalhados, envolvendo por exemplo microfósseis, isótopos da matéria orgânica e datações ${ }^{14} \mathrm{C}$. 
Esta variação de fácies deposicionais encontrada ao longo do testemunho de STO de Campos Verdes contrasta com a homogeneidade faciológica registrada nas diferentes trincheiras, em perfis transversais ao feixe de cordões da mesma área. Isso decorre do fato de que as fácies, por terem sido formadas sob NRM quase estável, possuem em escala regional distribuição estratigráfica sub-horizontal, cruzando as linhas de tempo (Fig.6.5). Assim, trincheiras abertas aproximadamente na mesma cota atravessam uma só fácies. Já a sondagem possui profundidade suficiente para cortar diferentes horizontes de fácies.

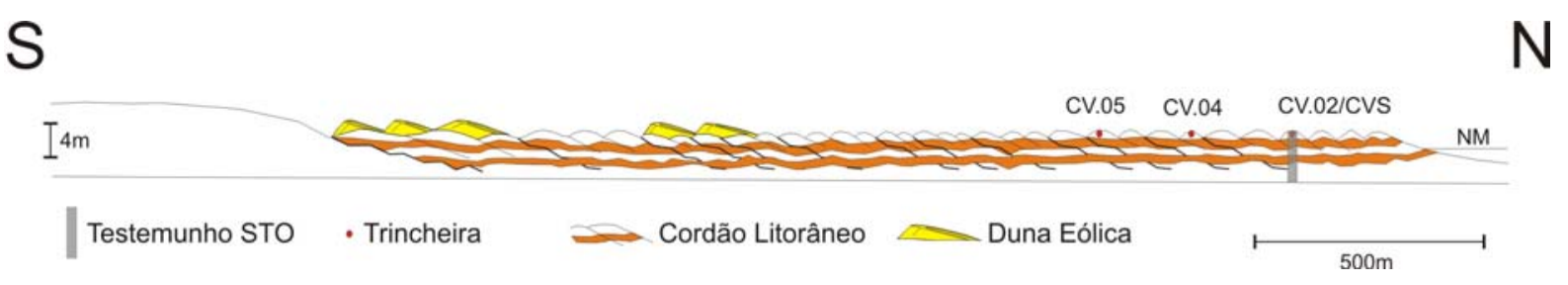

Figura 6.5 - Posição esquemática das amostras de trincheira e do furo de sondagem em relação à distribuição estratigráfica sub-horizontal das fácies formadas sob nível relativo do mar (NRM) quase estável, em Campos Verdes.

\subsubsection{Variação granulométrica em Campos Verdes}

Tanto na fácies ou feição morfológica de cordões litorâneos quanto na de dunas eólicas ocorrem principalmente depósitos de coloração cinza amarelado, dominados pela fração areia fina (até 95,25\% em massa), com areia muito fina subordinada (até 17,57\% em massa). No geral, não é possível observar estruturas, exceto nas exposições naturais a beira da desembocadura de um distributário do rio Tubarão, a NW da área, onde os depósitos da fácies de cordões litorâneos apresentam estratificações plano-paralelas incipientes, com marcas de raízes e mosqueamento no topo da seção (Fig. 6.6). 


\section{A)}
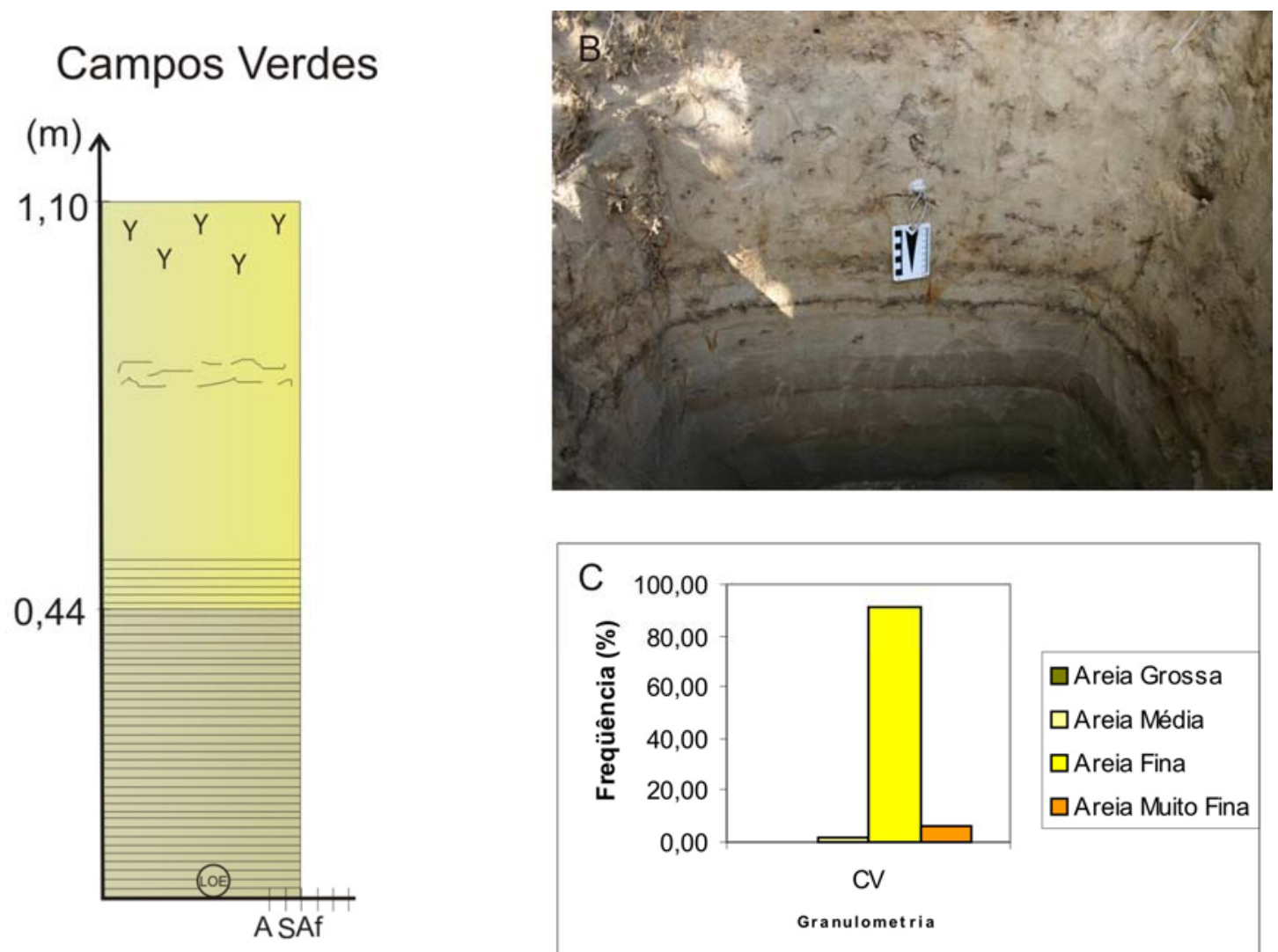

Figura 6.6 - Seção que representa a estratigrafia e sedimentologia tipo das amostras de cordões litorâneos de Campos Verdes (Ponto CV.04). A) Coluna esquemática. B) Exposição em trincheira natural. Areia cinza amarelada mosqueada, com lâminas estilolizadas de possíveis óxidos/hidróxidos de ferro coloidais. C) Histograma de distribuição granulométrica, evidenciando predomínio de areia fina.

A seguir, apresentam-se os resultados referentes à análise da variação das propriedades texturais ao longo de perfis transversais (duna e cordão) e longitudinal (cordão).

Com base na variação de atributos granulométricos em perfil transversal aos cordões (Fig.6.7), pode-se inferir tendência para afinamento (aumento do diâmetro médio na escala phi), melhora de seleção (queda de desvio-padrão) e diminuição de assimetria para norte, tanto nas amostras de cordão (Fig.6.7A), como nas de duna eólica (Fig.6.7B). A variação combinada "mais fino, melhor selecionado e mais negativo" coincide com um dos padrões indicadores de transporte sedimentar considerados seguros ou inequívocos por McLaren \& Bowles (1985). No presente caso, como se trata de tendência detectada transversalmente à sucessão de cordões, do mais antigo para o mais recente, a interpretação é de retrabalhamento sedimentar seletivo durante a progradação. Assim, a variação estudada refletiria o próprio crescimento da planície para norte. Para os coeficientes de determinação $\left(r^{2}\right)$ obtidos, o nível de significância resultou em 0,1 para o diâmetro médio, nas dunas, e 0,2 para diâmetro médio e desvio padrão, nos cordões, ou seja, a probabilidade de as correlações apresentadas nos gráficos serem inexistentes é de aproximadamente 10\% e $20 \%$ respectivamente. Já o desvio padrão (dunas) e a assimetria (cordão e duna) apresentaram 
probabilidade elevada de rejeição da hipótese nula (40\%). Sem considerar o dado de assimetria, não é possível relacionar essa tendência aos padrões indicadores de transporte (ou, neste caso, de retrabalhamento sedimentar por progradação) conforme McLaren \& Bowles (1985). Porém, é importante lembrar que o aumento de seleção relacionado a afinamento de granulometria é um indicador clássico de rumo de transporte e/ou retrabalhamento sedimentar (Evans 1939).

Em perfil longitudinal (Fig.6.7C), há tendência de engrossamento, melhora de seleção e assimetria mais positiva de $\mathrm{E}$ para $\mathrm{W}$, outro padrão indicador de transporte sedimentar. Nesse caso, o método foi aplicado a uma mesma linha de tempo, como proposto originalmente por McLaren \& Bowles (1985), e pode ser interpretado como resultante de transporte por deriva litorânea. Para os coeficientes de determinação $\left(r^{2}\right)$ obtidos, o nível de significância resultou igual a 0,4 , para diâmetro médio e desvio padrão, e 0,05 , para assimetria.
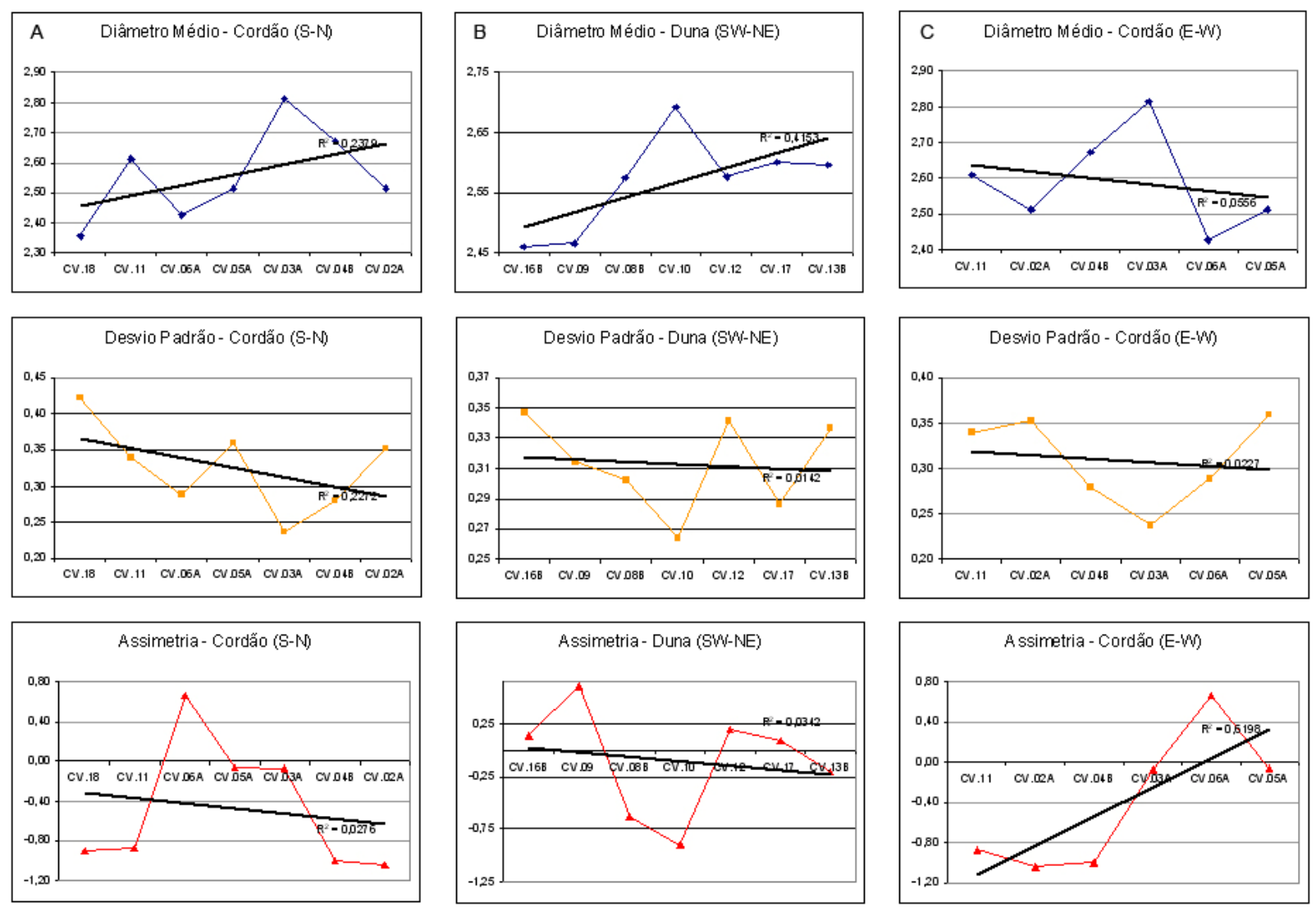

Figura 6.7 - Variação dos parâmetros estatísticos da distribuição granulométrica da fração areia. A) Para amostras de cordão, em perfil transversal aos alinhamentos, de S para N. B) Para amostras de duna eólica, em perfil transversal aos alinhamentos, de SW para NE. C) Para amostras de cordão, em perfil aproximadamente longitudinal à orientação predominante dos alinhamentos.

A alta probabilidade de rejeição da hipótese nula verdadeira, para alguns parâmetros estatísticos indicadores desta suposta tendência de retrabalhamento e transporte, pode ser explicada pela relativa homogeneidade textural apresentada pelas areias da planície, bem 
como pelos pequenos intervalos de distância entre os pontos de amostragem (em alguns casos, menores que $400 \mathrm{~m}$ ). Este segundo aspecto é uma das críticas apresentadas ao método de McLaren \& Bowles (1985) por Gao \& Collins (1991), segundo a qual a ordem dos padrões de distribuição granulométrica pode ser destruída ou obliterada quando as amostragens apresentam pequenos intervalos de distância, sob gradiente baixo nos parâmetros granulométricos. Dessa maneira, o fato de o teste de significância rejeitar a hipótese de existência de rumo preferencial de transporte sedimentar não quer dizer necessariamente que este transporte preferencial não tenha existido no sistema deposicional (Gao \& Collins 1991). Outra maneira de testar esses padrões é utilizar o software GSTAST (Grain Size Trend Analysis with Significant Test), desenvolvido por Chang et al. (2001), para inferir rumo de transporte sedimentar. Testou-se aqui a aplicação do software para verificar a hipótese retrabalhamento em perfil transversal. Os vetores aceitos indicaram transporte (no caso, retrabalhamento progressivo), grosso modo, para N (Fig. 6.8).

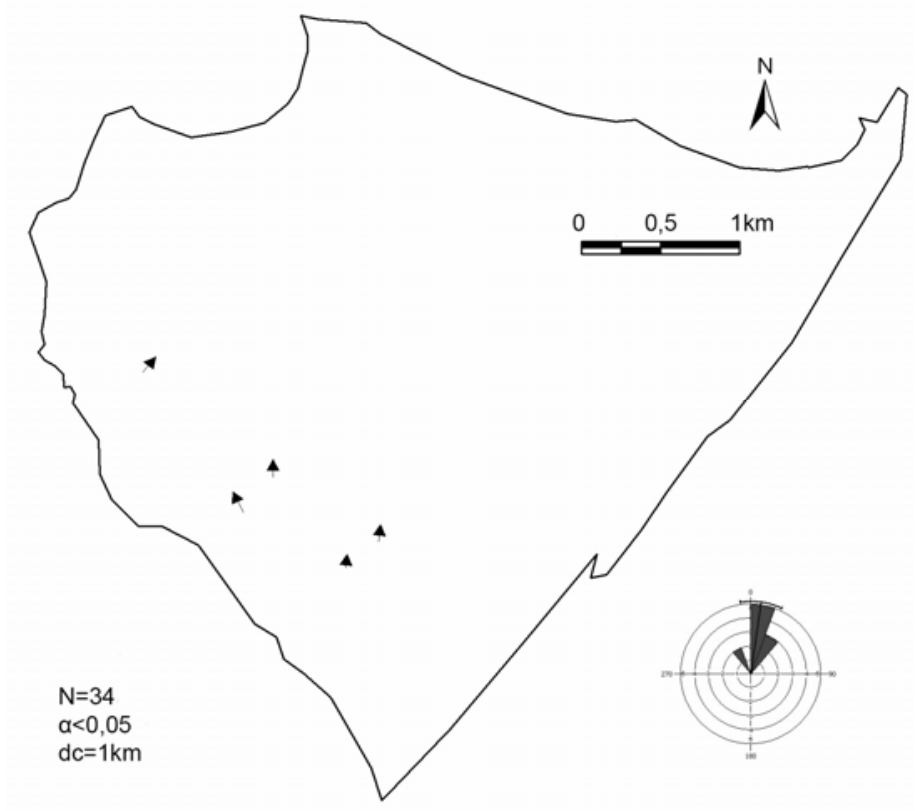

Figura 6.8 - Vetores de transporte e/ou retrabalhamento sedimentar aceitos pelo programa GSTAST, na planície de Campos Verdes. As magnitudes dos vetores, representadas pelos tamanhos das setas, indicam a consistência para cada possível rumo de transporte. Correspondem, no caso, a: 0,92, 1,12, $1,16,1,31$ e 1,51 (valores adimensionais).

Para os resultados de granulometria das amostras do furo de sondagem, observa-se pouca variação do diâmetro médio no intervalo inferior, de areia lamosa, com ligeiro engrossamento (Fig.6.9A), aumento do desvio padrão (Fig.6.9B) e diminuição da assimetria (Fig.6.9C), para cima. A piora ascendente de seleção e o ligeiro engrossamento com assimetria negativa sugerem aumento progressivo de grossos, compondo a cauda do lado esquerdo da distribuição (baixos valores de phi). A interpretação do significado desta variação seria prematura, pois faltam maiores informações sobre datações e condições paleoambientais baseadas em microfósseis. 
No intervalo superior, o diâmetro médio diminui em phi (engrossa) (Fig.6.9A), o desvio padrão cai (seleção melhora) (Fig.6.9B) e a assimetria fica mais positiva para o topo (Fig.6.9C). Esta tendência ascendente representa aumento de energia, com deslocamento da moda para o lado dos grossos, e crescente homogeneização de agentes/processos deposicionais, padrão esperado ao longo de uma sucessão de fácies deposicionais de borda lagunar cada vez mais rasas.
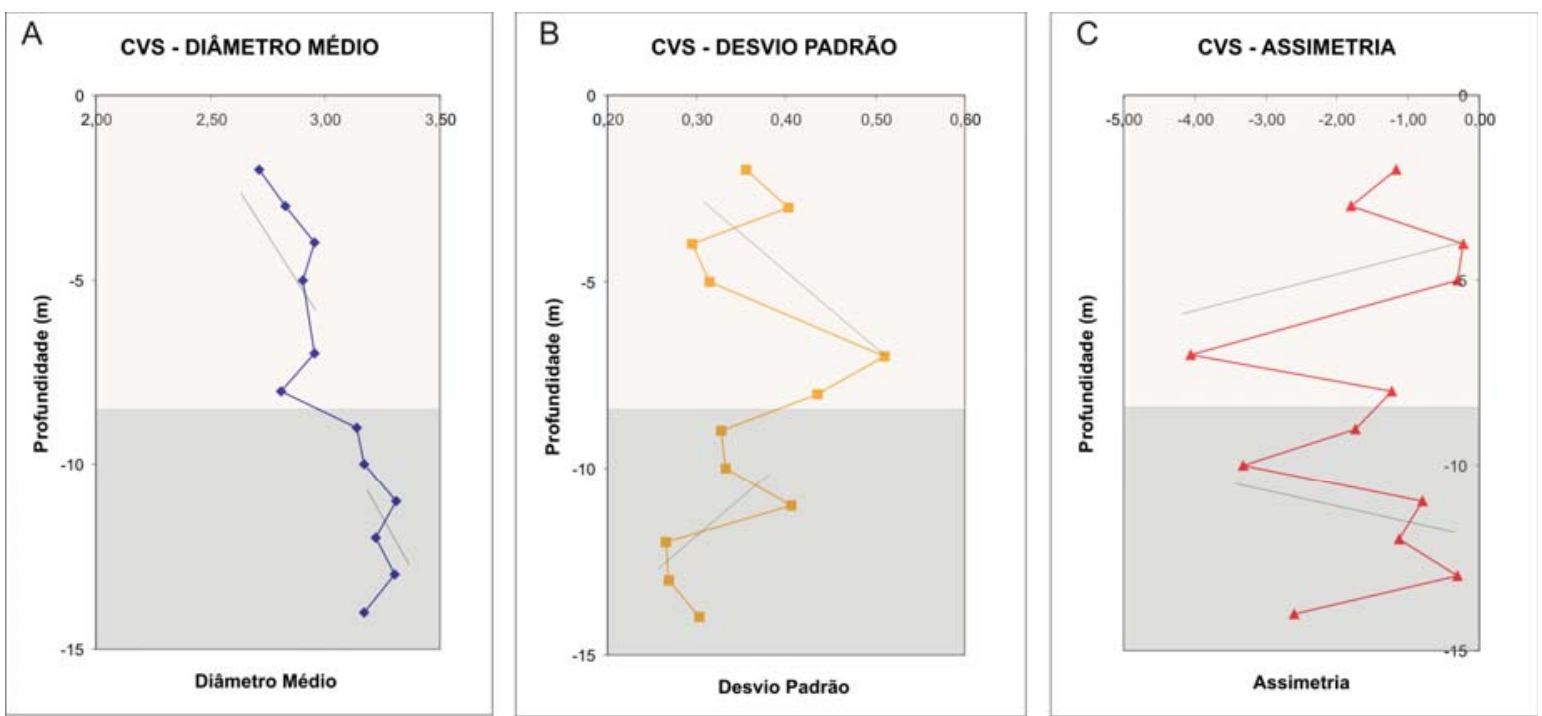

Figura 6.9 - Variação dos parâmetros estatísticos da distribuição granulométrica da fração areia para amostras do furo de sondagem realizado em Campos Verdes. A) Diâmetro médio (base $r^{2}=0,1233$ $\alpha=0,3$, topo $r^{2}=0,167 \alpha=0,3$ ). B) Desvio padrão (base $r^{2}=0,2138 \alpha=0,2$, topo $r^{2}=0,3436 \alpha=0,2$ ). C) Assimetria (base $r^{2}=0,442 \alpha=0,1$, topo $r^{2}=0,1331 \alpha=0,3$ ).

\subsubsection{Variação granulométrica no Ji}

Assim como em Campos Verdes, os sedimentos do Ji (amostras de cordões e dunas) apresentam coloração cinza amarelado e homogeneidade textural, com predomínio (até $94,31 \%$ em massa) da fração areia fina e presença subordinada (até $22,48 \%$ ) de areia muito fina .

Não foi possível observar estruturas sedimentares, provavelmente devido a sua obliteração por bioturbação e/ou pedogênse. Sintomático disso, marcas de raízes e mosqueamento são freqüentes (Fig.6.10). 
A)

Ji
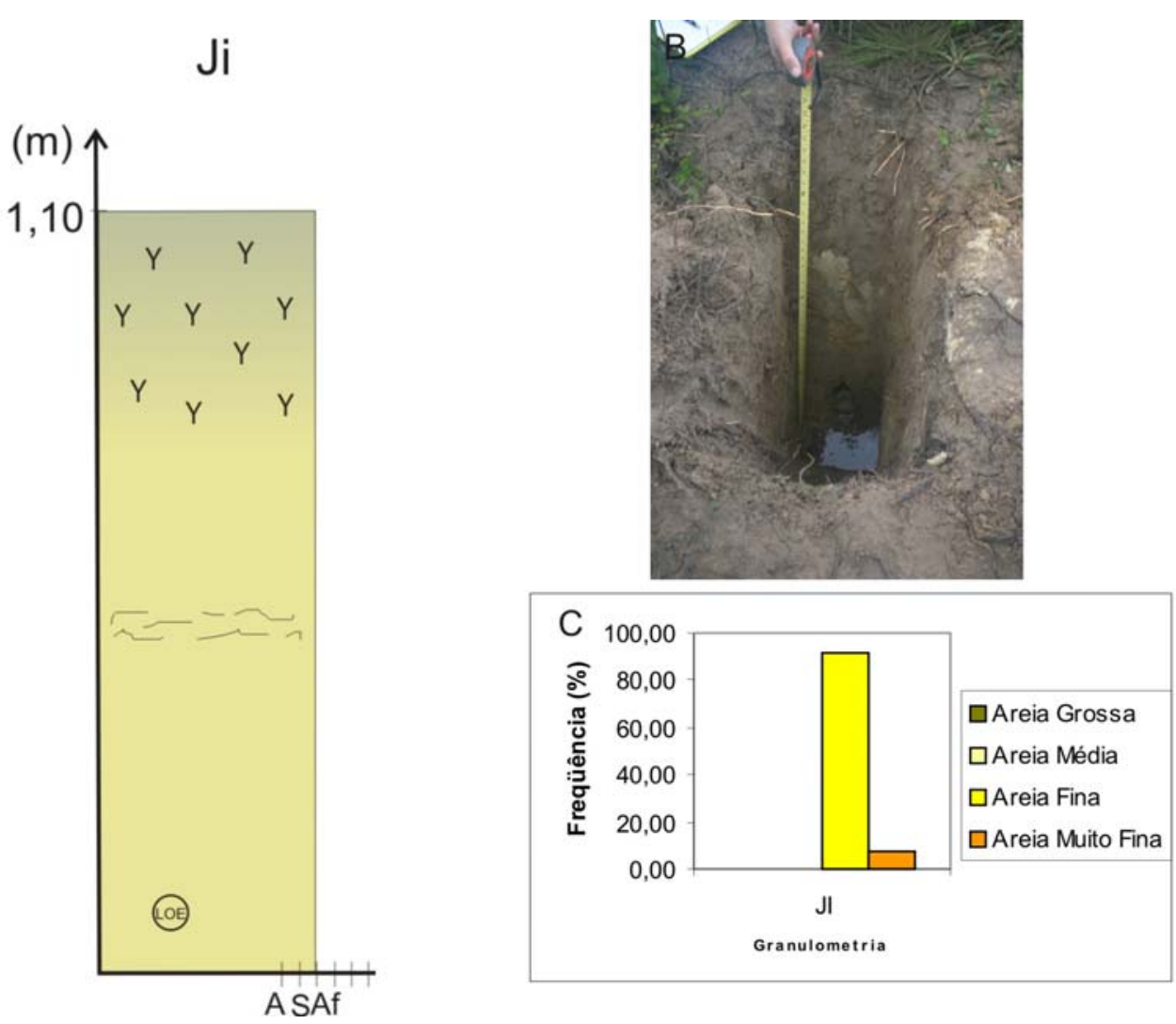

Figura 6.10 - Representação da estratigrafia e sedimentologia tipo das amostras de cordões litorâneos do Ji (Ponto Jl.10). A) Seção colunar esquemática. B) Exposição em trincheira de areia cinza amarelado, mosqueada. C) Histograma de distribuição granulométrica, evidenciando predomínio de areia fina, com areia muito fina subordinada.

A seguir, apresenta-se uma avaliação da variação transversal e longitudinal das propriedades granulométricas dos sedimentos de cordão da planície do Ji.

Com base na variação de atributos granulométricos em perfil transversal aos cordões (Fig.6.11), pode-se inferir tendência para engrossamento (diminuição do diâmetro médio na escala phi), melhora de seleção (queda de desvio-padrão) e aumento de assimetria para $E$, nas amostras de cordão (Fig.6.11A). A variação reflete o crescimento da planície nesse mesmo rumo, portanto o padrão McLaren de variação granulométrica "mais grosso, melhor selecionado e mais positivo", para E, pode ser atribuído a sucessivo retrabalhamento sedimentar no decorrer da progradação. Para os coeficientes de determinação $\left(r^{2}\right)$ obtidos, o nível de significância resultou em 0,2 para os parâmetros diâmetro médio e desvio padrão, ou seja, a probabilidade de as correlações apresentadas nos gráficos serem inexistentes é de aproximadamente $20 \%$. Já a assimetria apresenta baixa probabilidade de rejeição da hipótese nula (nível de significância igual a 0,01).

Em perfil longitudinal (Fig. 6.11B), há tendência de engrossamento, melhora de seleção e assimetria mais positiva para $\mathrm{N}$, mesmo padrão indicador de transporte sedimentar encontrado transversalmente aos cordões rumo E. Neste caso, como proposto originalmente por McLaren \& Bowles (1985), a variação está relacionada ao transporte, e pode ser atribuída ao efeito da corrente de deriva litorânea residual para NNE. Para os coeficientes de 
determinação $\left(r^{2}\right)$ obtidos, o nível de significância resultou igual a 0,2, para diâmetro médio, 0,3 para o desvio padrão e 0,05 para assimetria.
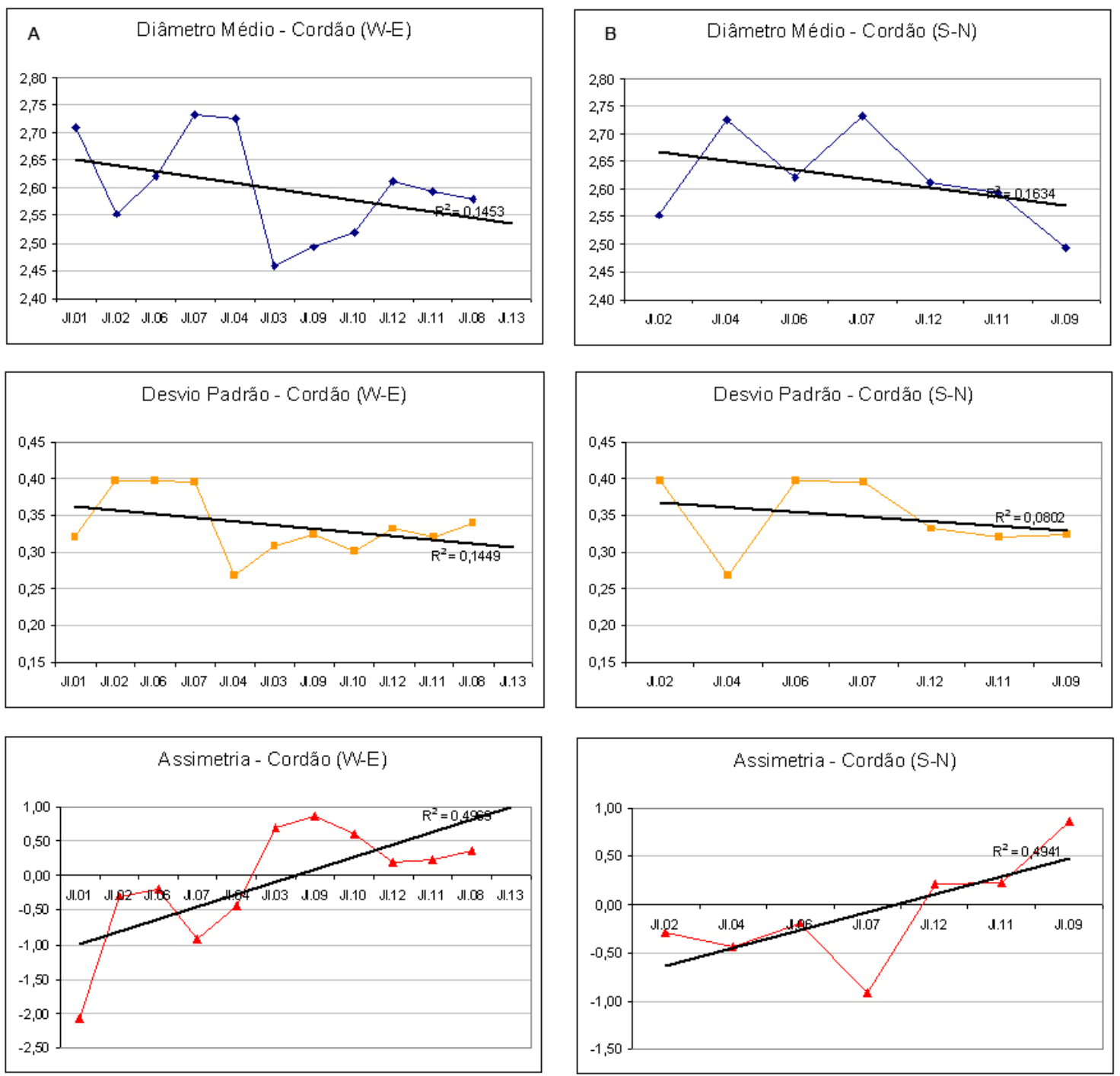

Figura 6.11 - Variação dos parâmetros estatísticos da distribuição granulométrica da fração areia. A) Para amostras de cordão em perfil transversal aos alinhamentos, de W para E. B) Para amostras de cordão em perfil aproximadamente longitudinal à orientação predominante dos alinhamentos, de $S$ para N.

Os padrões de tendência granulométrica foram testados no software GSTAST (Chang et al. 2001), para inferir rumo de retrabalhamento e transporte sedimentar. Os vetores aceitos indicaram transporte para E e NE (Fig. 6.12), o que pode ser atribuído ao efeito combinado do retrabalhamento progradacional, para $E$, com o transporte preferencial longitudinal, para NNE, devido à corrente de deriva litorânea vigente na época de formação dos cordões. 


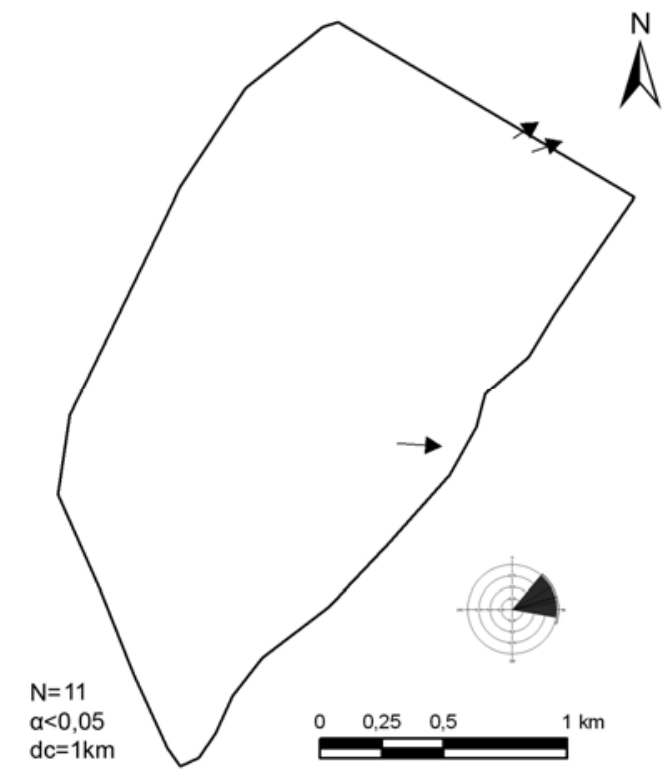

Figura 6.12 - Vetores de transporte e/ou retrabalhamento sedimentar aceitos pelo programa GSTAST, na planície do Ji. As magnitudes dos vetores, representadas pelos tamanho das setas, indicam a consistência para cada possível rumo de transporte. Correspondem, no caso, a: 1,21, 1,33 e 1,80 (valores adimensionais).

\subsubsection{Granulometria (Campos Verdes vs. Ji)}

Para comparar as características granulométricas dos sedimentos de Campos Verdes e do Ji, foram construídos boxplots que representam os valores médios e intervalos interquartis de cada categoria faciológica de amostras (duna eólica versus cordão), agrupadas por planície (Fig.6.13).

Os gradientes baixos entre as estatísticas descritivas de granulometria (diâmetro médio, desvio padrão, assimetria e curtose) encontradas para as amostras de duna e cordão de Campos Verdes (Fig. 6.13) indicam elevada homogeneidade textural. Chama a atenção o fato de que os intervalos interquartis de duna e cordão sobrepõem-se entre si em todos os parâmetros analisados. Uma explicação plausível é a de que sedimentos de cordões teriam servido como fonte imediata para dunas eólicas e vice-versa, num processo de retrabalhamento sucessivo. Já na planície do Ji, apesar da sobreposição de parte dos intervalos interquartis, observa-se maior distinção entre os sedimentos de cordão e duna, com tendência para sedimentos de dunas mais finos e melhor selecionados que os de cordões (Fig. 6.13). Esta maior diferença entre duna e cordão no Ji pode em parte estar relacionada ao maior porte e extensão das paleodunas nesta planície, as quais teriam portanto sofrido transporte mais longo e seletivo desde a fonte praial.

Quando se comparam sedimentos de cordões das duas planícies, nota-se, apesar da grande semelhança geral, ligeira diferença no desvio padrão, mais elevado (pior seleção) no Ji que em Campos Verdes. 


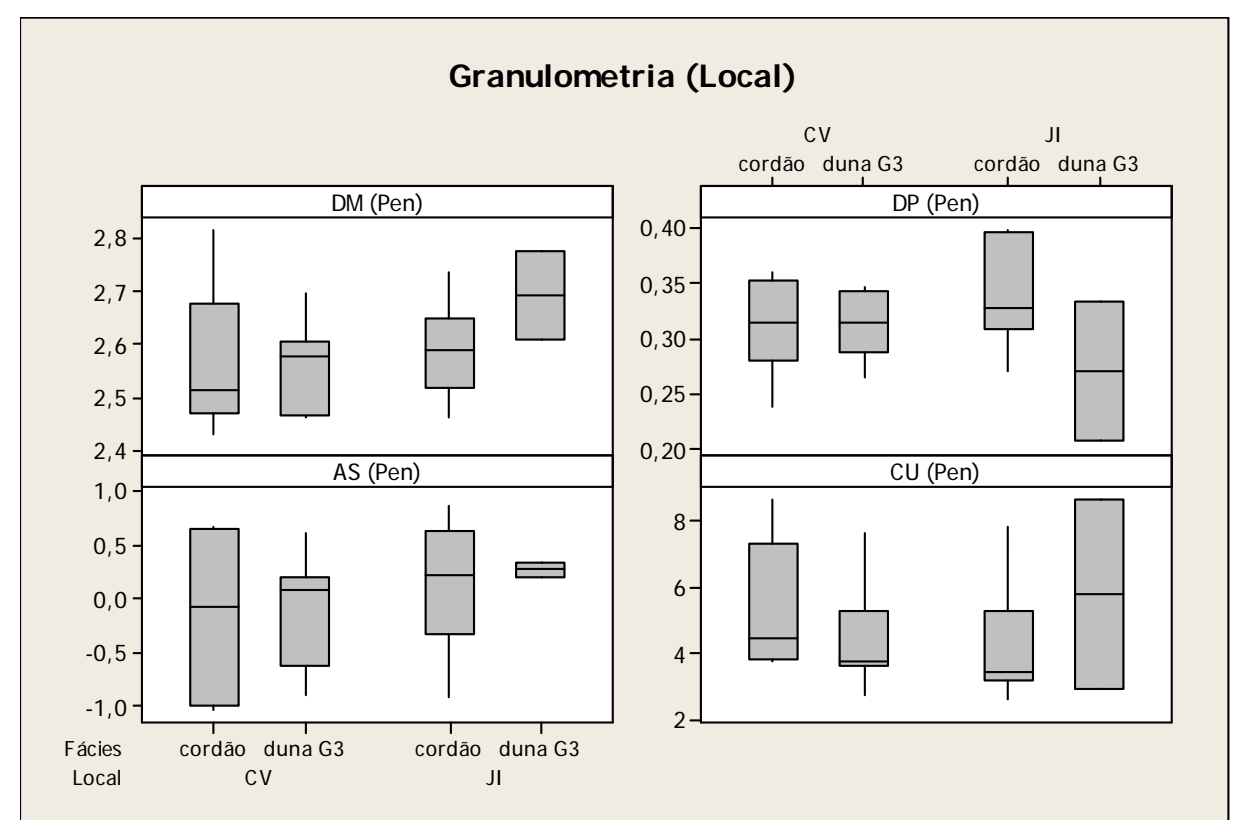

Figura 6.13 - Boxplots dos parâmetros granulométricos para amostras de cordão e paleoduna de Campos Verdes ( $\left.\mathrm{N}_{\text {cordão }}=7, \mathrm{~N}_{\text {duna }}=7\right)$ e Ji $\left(\mathrm{N}_{\text {cordão }}=10, \mathrm{~N}_{\text {duna }}=2\right)$.

É possível inferir que os parâmetros granulométricos são pouco sensíveis a controles de seleção locais, sendo que as semelhanças configuram características comuns herdadas da área fonte mediata e o retrabalhamento cordão-duna potencializa a homogeneização.

Para o agrupamento total de amostras de cordão $(\mathrm{N}=17)$, duna $(\mathrm{N}=9)$ e margempontal $(\mathrm{N}=5)$, nota-se boa distinção entre as fácies de margem-pontal das demais (Fig. $6.14 \mathrm{e}$ 6.15). As amostras de margem-pontal são mais grossas e pior selecionadas que as demais, com assimetria mais negativa e curtose elevada. Essa diferença pode ser explicada devido ao menor retrabalhamento dessa porção da planície. De acordo com o modelo de evolução de Campos Verdes (Giannini 1993, Tanaka 2007, Tanaka et al. 2009a), o pontal corresponderia ao início da fase de compartimentação de uma extensa e alongada laguna inicial, para pequenas lagunas equidimensionais e semi-circulares, assim como nos modelos de circulação lagunar de Zenkovitch (1971). Dependendo das condições de aporte e hidrodinâmica, o pontal pode, como em Campos Verdes, reter sedimentos e dar origem à formação de uma planície de cordões. Desse modo, o pontal funcionaria como armadilha para o acúmulo de sedimentos que seriam retrabalhados durante a progradação desta planície. 


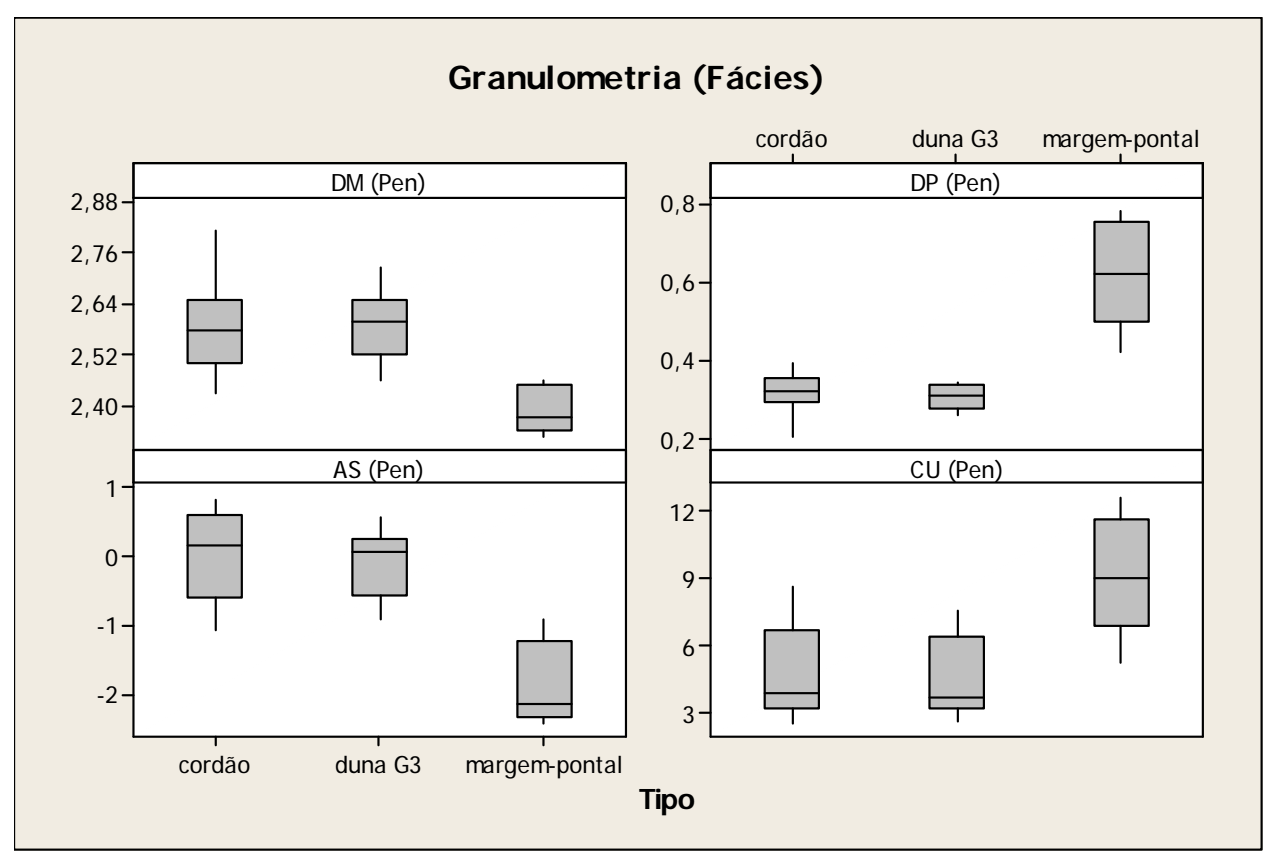

Figura 6.14 - Boxplots das variáveis granulométricas de amostras das planícies de Campos Verdes e Ji, agrupadas por categoria faciológica (cordão litorâneo, paleoduna da geração 3 e margem/pontal lagunar).

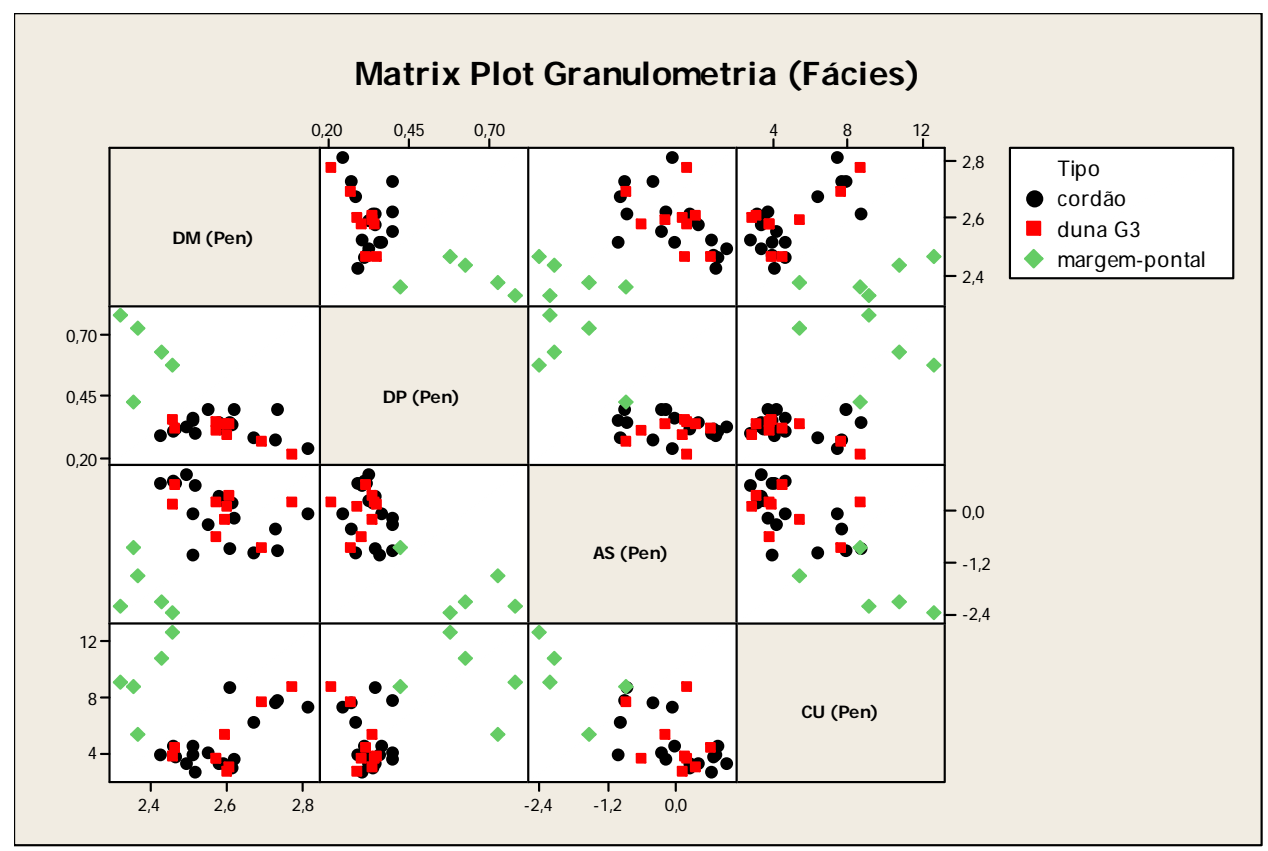

Figura 6.15 - Matriz de dispersão das variáveis granulométricas de amostras das planícies de Campos Verdes e Ji, agrupadas por categoria faciológica (cordão litorâneo, paleoduna da geração 3 e margem/pontal lagunar). 


\subsection{Minerais pesados}

\subsubsection{Variação mineralógica em Campos Verdes}

$\mathrm{Na}$ fração não magnética da classe granulométrica areia muito fina, foram encontrados os seguintes minerais transparentes não-micáceos, em ordem decrescente de abundância média: turmalina, zircão, epídoto, hornblenda, estaurolita, cianita, rutilo, sillimanita, granada, tremolita, clinopiroxênio (augita/diopsídio/pigeonita), andaluzita, hiperstênio (opx) e glauconita. Observou-se também, em duas amostras, a presença de anatásio. A Tabela 6.1 apresenta as freqüências de minerais pesados terrígenos encontrados nos sedimentos de Campos Verdes.

Tabela 6.1 - Freqüências percentuais médias dos minerais pesados terrígenos encontrados na fração areia muito fina dos sedimentos de Campos Verdes: turmalina (tur), zircão (zir), epídoto (epi), hornblenda (hbl), estaurolita (est), cianita (kya), rutilo (rut), sillimanita (sil), granada (grt), tremolita (tre), clinopiroxênio (pigeonita/diopsídio/augita, cpx), andaluzita (and), hiperstênio (opx), glauconita (glc).

\begin{tabular}{|c|c|c|c|c|c|c|c|c|c|c|c|c|c|c|}
\hline & tur & zir & epi & hbl & est & kya & rut & sil & grt & tre & cpx & and & opx & glc \\
\hline $\mathbf{2 1 - 5 0 \%}$ & $\mathrm{X}$ & & & & & & & & & & & & & \\
\hline $\mathbf{6 - 2 0 \%}$ & & $\mathrm{X}$ & $\mathrm{X}$ & $\mathrm{X}$ & $\mathrm{X}$ & $\mathrm{X}$ & & & & & & & & \\
\hline $\mathbf{2 - 5 \%}$ & & & & & & & $\mathrm{X}$ & & & & & & & \\
\hline$<\mathbf{2 \%}$ & & & & & & & & $\mathrm{X}$ & $\mathrm{X}$ & $\mathrm{X}$ & $\mathrm{X}$ & $\mathrm{X}$ & $\mathrm{X}$ & $\mathrm{X}$ \\
\hline
\end{tabular}

Zircão apresenta-se em grãos euédricos prismáticos a subédricos arredondados, por vezes com alto grau de esfericidade e frequentemente com inclusões (Fig.6.16A). Fraturamento interno observa-se eventualmente. Turmalina ocorre nas cores parda, verde e, em menor freqüência, azul, em formas tanto equidimensionais arredondadas como euédricas a subédricas prismáticas (Fig.6.16B). Frequentemente, exibe inclusões. Epídoto apresenta-se anguloso, com aspecto corroído (Fig.6.16C) e relevo eventualmente alterado, ou em grãos equidimensionais bem arredondados, com relevo alto preservado. Hornblenda ocorre em grãos subédricos prismáticos, nas cores verde, verde amarronzado e, em alguns casos, pardo avermelhado (Fig.6.16D). Dentre os minerais tipicamente metamórficos, estaurolita (Fig.6.16E), cianita (Fig.6.16F) e sillimanita (Fig.6.16G), o primeiro é o mais abundante e ocorre em grãos subangulosos a subarredondados. Rutilo apresenta-se em cristais avermelhados, arredondados a subarredondados (Fig.6.16H). 

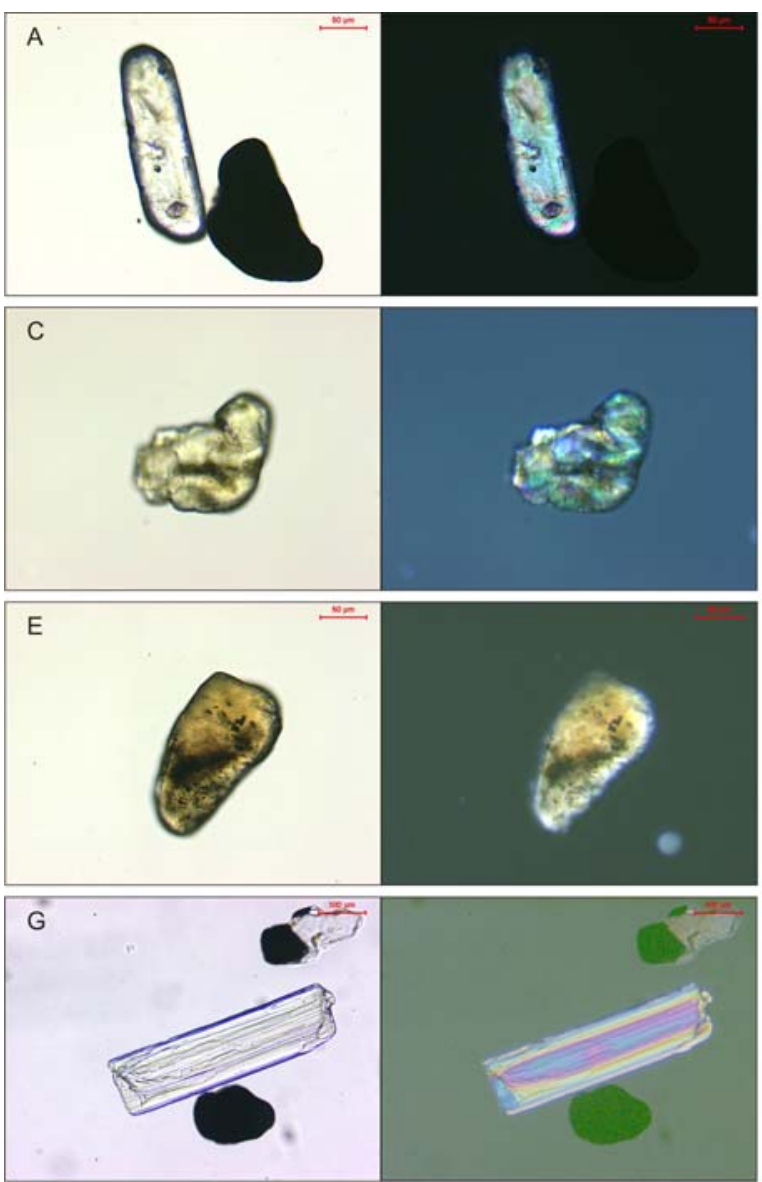

Figura 6.16 - Aspectos típicos de alguns minerais pesados observados ao microscópio petrográfico, sob polarizadores paralelos e cruzados. A) Zircão prismático biterminado, subarredondado, com inclusões. B) Turmalina parda subédrica prismática, com inclusões alinhadas. C) Epídoto anédrico equidimensional, com aspecto corroído.D) Hornblenda alongada. E) Estaurolita subarredondada. F) Cianita. G) Sillimanita prismática. H) Rutilo avermelhado, arredondado.

Ao exame da variação transversal e em área dos índices de maturidade mineralógica (Fig.6.17A e 6.18A) para amostras de cordão e paleoduna eólica, ressalta-se a maior freqüência de componentes instavéis (iINS) em relação a ultraestáveis (iZTR) no norte da planície e a tendência geral de queda de maturidade mineralógica rumo $\mathrm{N}$ e NE. Este padrão de variação espacial da mineralogia pode ser explicado, isolada ou combinadamente, por pelo menos três hipóteses distintas. A primeira é a concentração progressiva, por seleção hidráulica durante o retrabalhamento progradacional, de minerais pesados relativamente menos densos, na sua maioria instáveis. A segunda hipótese explica a maior maturidade mineralógica dos sedimentos da parte sudoeste da planície com base em sua idade mais antiga: haja visto o crescimento gradual da planície de sul para norte, os depósitos situados mais ao sul teriam sofrido maior tempo de atuação da dissolução pós-deposicional, com eliminação preferencial de minerais instáveis. A terceira explicação está relacionada a uma particularidade da dinâmica costeira responsável pela formação da planície, segundo a qual haveria maior influência do aporte de sedimentos "novos", ricos em instáveis, no setor formado ao final da progradação (norte), através do aporte vazante da desembocadura da Entrada da Barra, por sua vez relacionado ao suprimento do rio Tubarão. 
Para testar a hipótese de seleção hidráulica, foram construídos gráficos de variação e mapas de interpolação do iTZ (Fig.6.17 e 6.18). O resultado encontrado, aumento do iTZ rumo $\mathrm{N}$, reforça a hipótese de controle hidráulico na variação espacial da mineralogia. Para testar a hipótese de dissolução pós-deposicional, foram construídos gráficos de variação do iHT para amostras de cordão e duna e mapas de interpolação para amostras de cordão (Fig.6.17 e 6.18). O resultado encontrado, aumento para norte no iHT, é coerente com a hipótese de menor tempo de atuação da dissolução pós-deposicional, isto é, menor eliminação química de hornblenda, na porção norte da planície. Porém, a variação encontrada no $\mathrm{iHT}$ pode ao mesmo tempo ser usada como argumento a favor da terceira hipótese, a de influência crescente ao longo do tempo (para norte) da frente deltaica do rio Tubarão, desde que os sedimentos deste rio sejam de fato menos maturos e, assim, relativamente enriquecidos em hornblenda e empobrecidos em turmalina. Dados quantitativos inéditos obtidos por D.R. Nascimento Jr., para a assembléia de minerais pesados transparentes não micáceos do delta do Tubarão, indicam, em comparação com a planície de Campos Verdes, concentrações médias mais altas de minerais pesados pouco estáveis, como cianita (17\%), estaurolita (17\%) e hornblenda (12\%), e concentração média mais baixa de turmalina (6\%). Desse modo, é possível, de fato, que a elevação no iHT para norte reflita um incremento na influência de sedimentos fornecidos pelo rio Tubarão, conforme evocado na terceira hipótese. A assembléia de minerais instáveis das amostras de trincheira não apresentou características texturais de dissolução química pós-deposicional, o que reforça o argumento apresentado anteriormente.

Guedes (2009), em estudo de minerais pesados nos sedimentos holocênicos na llha Comprida, SP, argumenta que o iHT é mais sensível a proveniência do que a dissolução, para os sedimentos analisados. Analogamente, Sawakuchi et al. (2009) conclui que a dissolução química não é o fator de controle mais importante na variação de MPs ao longo das sucessivas gerações eólicas da região de Imbituba-Jaguaruna, pois o iHT mostra maior variação entre sedimentos do próprio Holoceno de que quando se comparam sedimentos do Pleistoceno e Holoceno; em outras palavras, sedimentos recém-fornecidos de fontes no continente seriam menos maturos se comparados a sedimentos pleistocênicos retrabalhados.

Como teste adicional para a hipótese de influência da fonte, associada ao fornecimento pelo rio Tubarão, avaliou-se o comportamento espacial do iRZ. A variação encontrada neste índice em Campos Verdes (Fig. 6.18D), apesar de não linear, confirma a possibilidade de mudança de área fonte ao longo do tempo (de E e SE para W e NW), o que constitui reforço adicional para a hipótese de renovação ou incremento da influência do aporte deltaico sobre a planície de cordões. Deve-se ressalvar, entretanto, que a baixa freqüência do mineral rutilo nas amostras estudadas pode comprometer a interpretação do iRZ. 
Quanto à variação de atributos mineralógicos em perfil longitudinal ao cordão, nota-se aumento de ilNS em detrimento do iZTR na porção oeste da planície (Fig.6.17C), acompanhada de aumento de iTZ e iHT (Fig.6.17C e 6.18C). Essa combinação de variações, admitida a hipótese de controle hidráulico sobre a distribuição dos sedimentos numa mesma linha de tempo, pode ser interpretada como reflexo de paleoderiva litorânea dirigida para W.
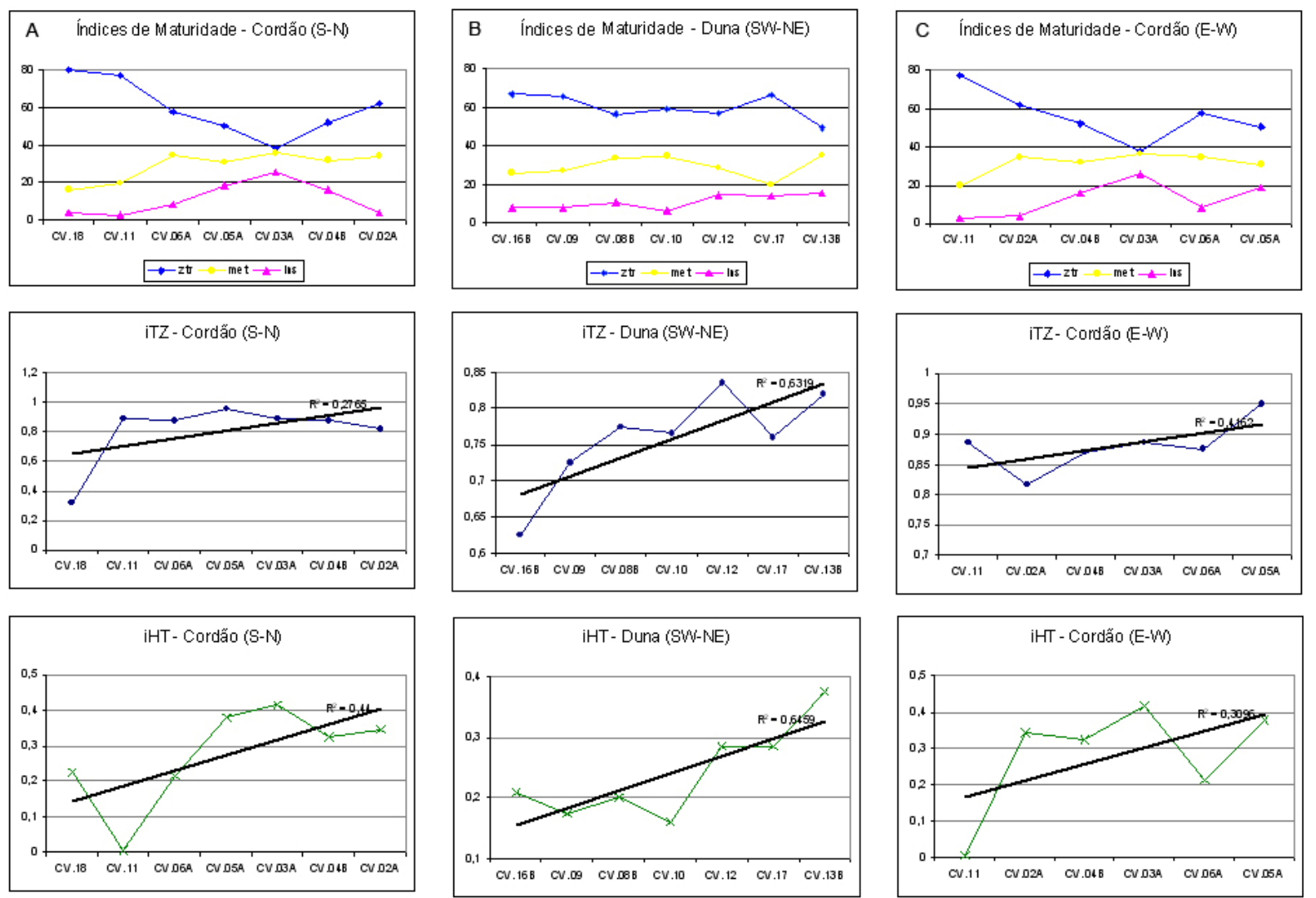

Figura 6.17 - Índices de minerais pesados da fração areia muito fina. A) Variação dos índices em perfil transversal para amostras de cordões litorâneos, de S para N. B) Variação dos índices em perfil transversal para amostras de dunas eólicas, de SW para NE. C) Variação dos índices em perfil longitudinal para amostras de cordões litorâneos, de E para W. 
A

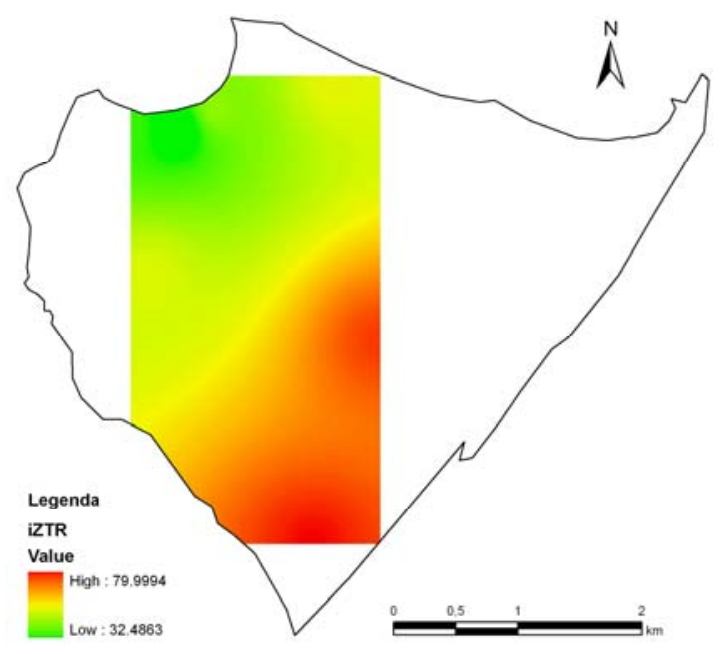

C

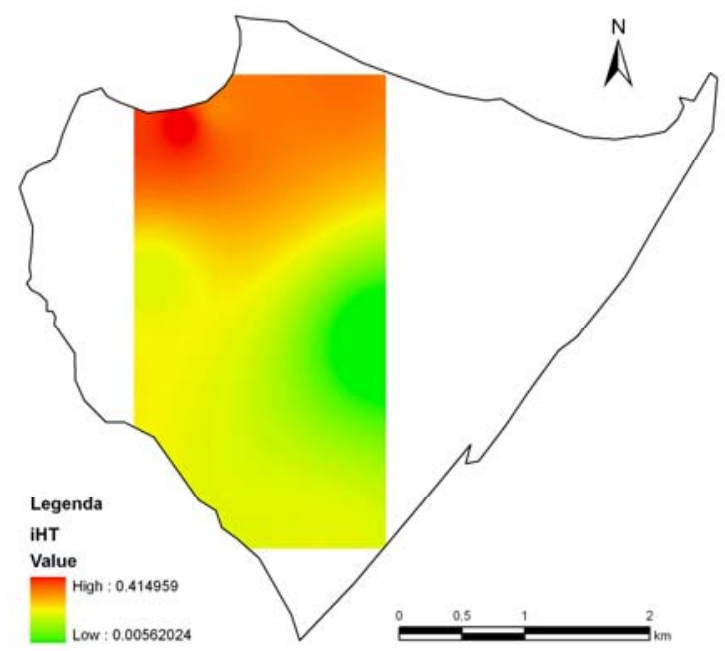

B

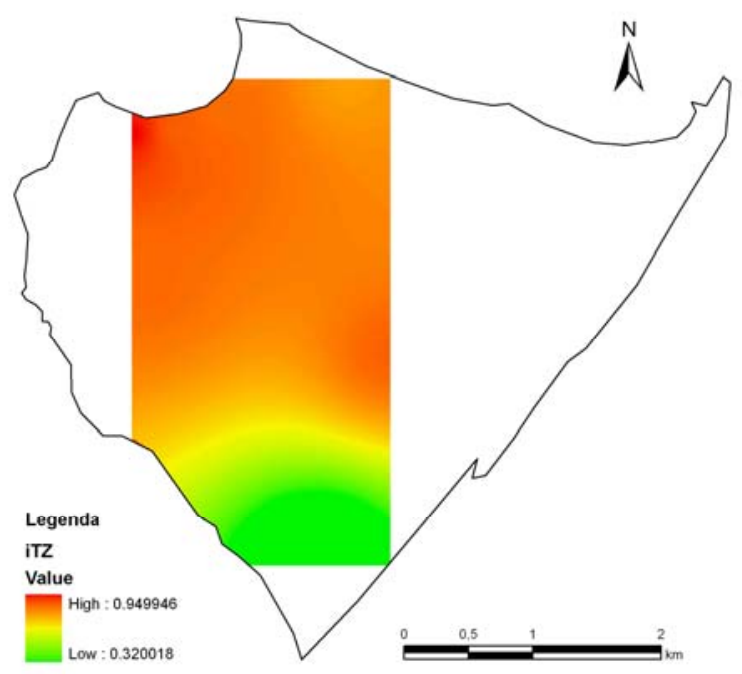

D

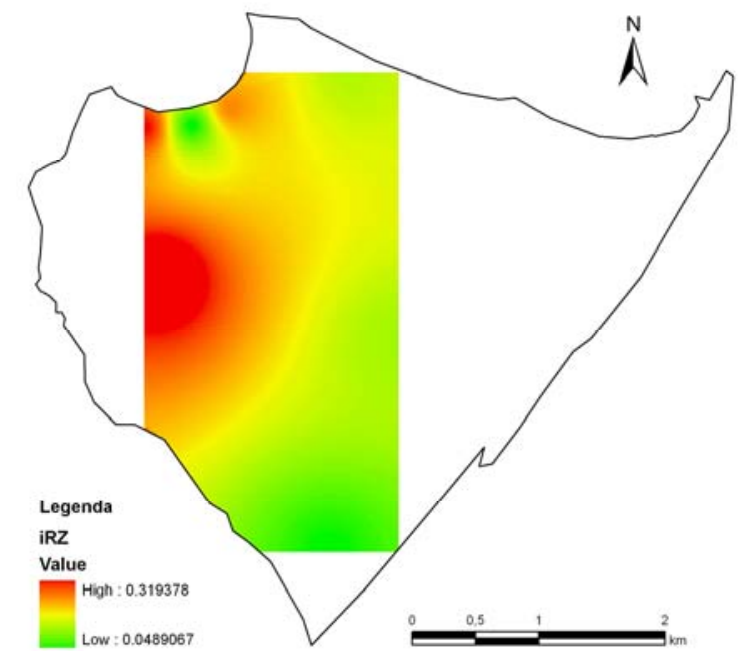

Figura 6.18 - Variação espacial de índices de minerais pesados da fração areia muito fina: A) iZTR. B) iTZ. C) iHT. D) iRZ. Valores mais altos estão representados por cores mais quentes (vermelho)

As amostras do furo de sondagem registram dois padrões principais diferentes de variação de minerais pesados na vertical, relativos aos intervalos de areia argilosa com bioclastos e de areia fina (Fig.6.19).

No intervalo inferior, de areia argilosa, o iZTR diminui e o ilNS aumenta para cima, o que caracteriza queda ascendente de maturidade mineralógica (Fig.6.19A). Já os índices de controle não apresentam variação significativa, exceto ligeiro aumento ascendente do iHT (Fig.6.19B). O aumento de ultraestáveis e de iHT nos estratos mais antigos, na ausência de variação de outros índices de controle, pode ser atribuído ao efeito crescente, com o tempo, da dissolução pós-deposicional de minerais instáveis. Em sedimentos arenosos junto à baía de Paranaguá, tendência semelhante, encontrada em testemunhos rasos, foi interpretada desse modo (Giannini et al. 1997). 
No intervalo superior, ocorre o padrão inverso, com aumento do iZTR e diminuição do iINS para o topo (Fig.6.19A). Entre os índices de controle, tem-se aumento ascendente do iTZ e iHT, acompanhado de diminuição do iRZ (Fig.6.19B). Essas variações não podem ser interpretadas tão facilmente quanto as encontradas no feixe de cordões. Enquanto, nos feixes, comparavam-se amostras de mesma fácies, aqui as variações certamente envolvem mudanças hidráulicas ligadas ao fato de se tratar de sucessão de fácies diferentes, na escala de vários metros de espessura.
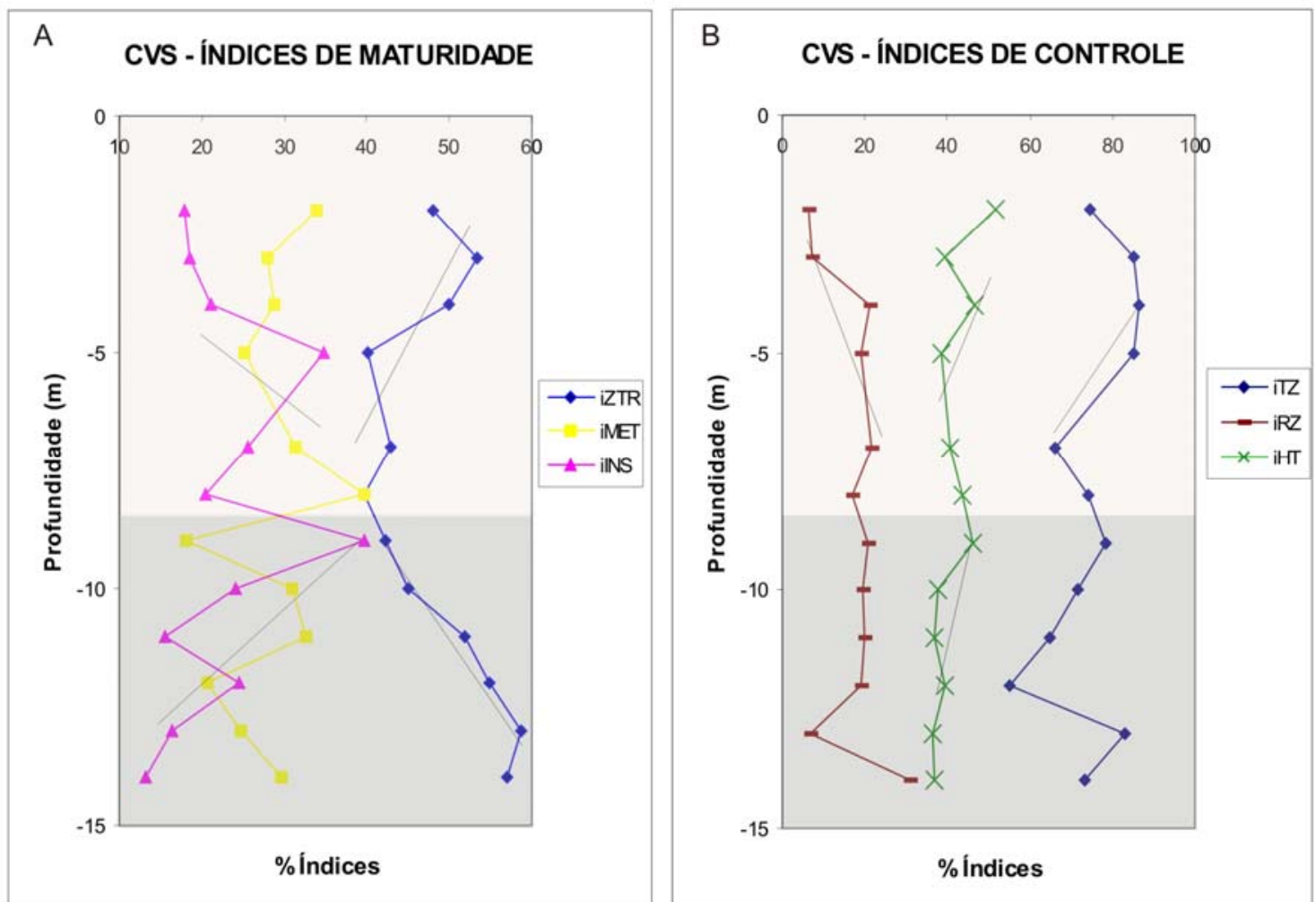

Figura 6.19 - Variação dos índices de minerais pesados da fração areia muito fina para amostras do furo de sondagem realizado em Campos Verdes. A) Índices de maturidade iZTR (base $r^{2}=0,8947$ $\alpha=0,005$ e topo $r^{2}=0,5892 \alpha=0,05$ ), iMET (base $r^{2}=0,2474 \alpha=0,4$ e topo $r^{2}=0,4434 \alpha=0,1$ ), iINS (base $r^{2}=0,6443 \alpha=0,05$ e topo $r^{2}=0,0997 \alpha=0,3$ ). B) Índices de controle iHT (base $r^{2}=0,4501 \alpha=0,1$, topo $r^{2}=0,1922 \alpha=0,2$ ), iTZ (topo $r^{2}=0,6397 \alpha=0,05$ e base $r^{2}=0,0027 \alpha>0,4$ ), iRZ (base $r^{2}=0,0728 \alpha>0,4$ e topo $\left.r^{2}=0,4761 \alpha=0,2\right)$.

\subsubsection{Variação mineralógica no Ji}

$\mathrm{Na}$ fração não magnética da classe granulométrica areia muito fina, foram registrados nos sedimentos da planície do Ji os seguintes minerais transparentes não-micáceos, em ordem decrescente de abundância média: zircão, turmalina, hornblenda, epídoto, cianita, rutilo, estaurolita, sillimanita, hiperstênio (opx), clinopiroxênio (augita/diopsídio/pigeonita), granada e andaluzita. A Tabela 6.2 apresenta as freqüências de minerais pesados terrígenos encontrados. 
Tabela 6.2 - Freqüências percentuais médias dos minerais pesados terrígenos encontrados na fração areia muito fina dos sedimentos da planície do Ji: zircão (zir), turmalina (tur), hornblenda (hbl), epídoto (epi), cianita (kya), rutilo (rut), estaurolita (est), sillimanita (sil), hiperstênio (opx), clinopiroxênio (pigeonita/diopsídio/augita, cpx), granada (grt) e andaluzita (and).

\begin{tabular}{|c|c|c|c|c|c|c|c|c|c|c|c|c|}
\hline & zir & tur & hbl & epi & kya & rut & est & sil & opx & cpx & grt & and \\
\hline $\mathbf{2 1 - 5 0 \%}$ & $\mathrm{X}$ & $\mathrm{X}$ & & & & & & & & & & \\
\hline $\mathbf{6 - 2 0 \%}$ & & & $\mathrm{X}$ & $\mathrm{X}$ & $\mathrm{X}$ & & & & & & & \\
\hline $\mathbf{2 - 5 \%}$ & & & & & & $\mathrm{X}$ & $\mathrm{X}$ & & & & & \\
\hline$<\mathbf{2 \%}$ & & & & & & & & $\mathrm{X}$ & $\mathrm{X}$ & $\mathrm{X}$ & $\mathrm{X}$ & $\mathrm{X}$ \\
\hline
\end{tabular}

Zircão (Fig.6.20A) apresenta-se em grãos euédricos prismáticos (curtos, ou em alguns casos, alongados) a anédricos, arredondados a muito arredondados, e freqüentemente exibe inclusões. Os grãos prismáticos podem apresentar anéis de crescimento e aspecto metamíctico. Turmalina ocorre nas cores parda e verde, em formas tanto equidimensionais arredondadas como euédricas a subédricas prismáticas e freqüentemente apresenta inclusões (Fig.6.20B). Hornblenda ocorre como prismas subédricos, com aspecto corroído ou sulcado, principalmente na cor verde amarronzado e, em alguns casos, pardo avermelhado (Fig.6.20C). Epídoto, apresenta-se subarredondado (Fig.6.20D) ou em grãos equidimensionais bem arredondados. Cianita ocorre em diversas formas, desde prismática alongada (Fig.6.20E) até anédrica angulosa. Rutilo apresenta-se em cristais avermelhados (Fig.6.20F), arredondados a subarredondados, com formas muito variáveis, em alguns casos geminado. Estaurolita também apresenta geminação (Fig.6.20G). Granada é menos frequente e pode exibir crateramento em padrão triangular ou losangular (Fig.6.20H). 

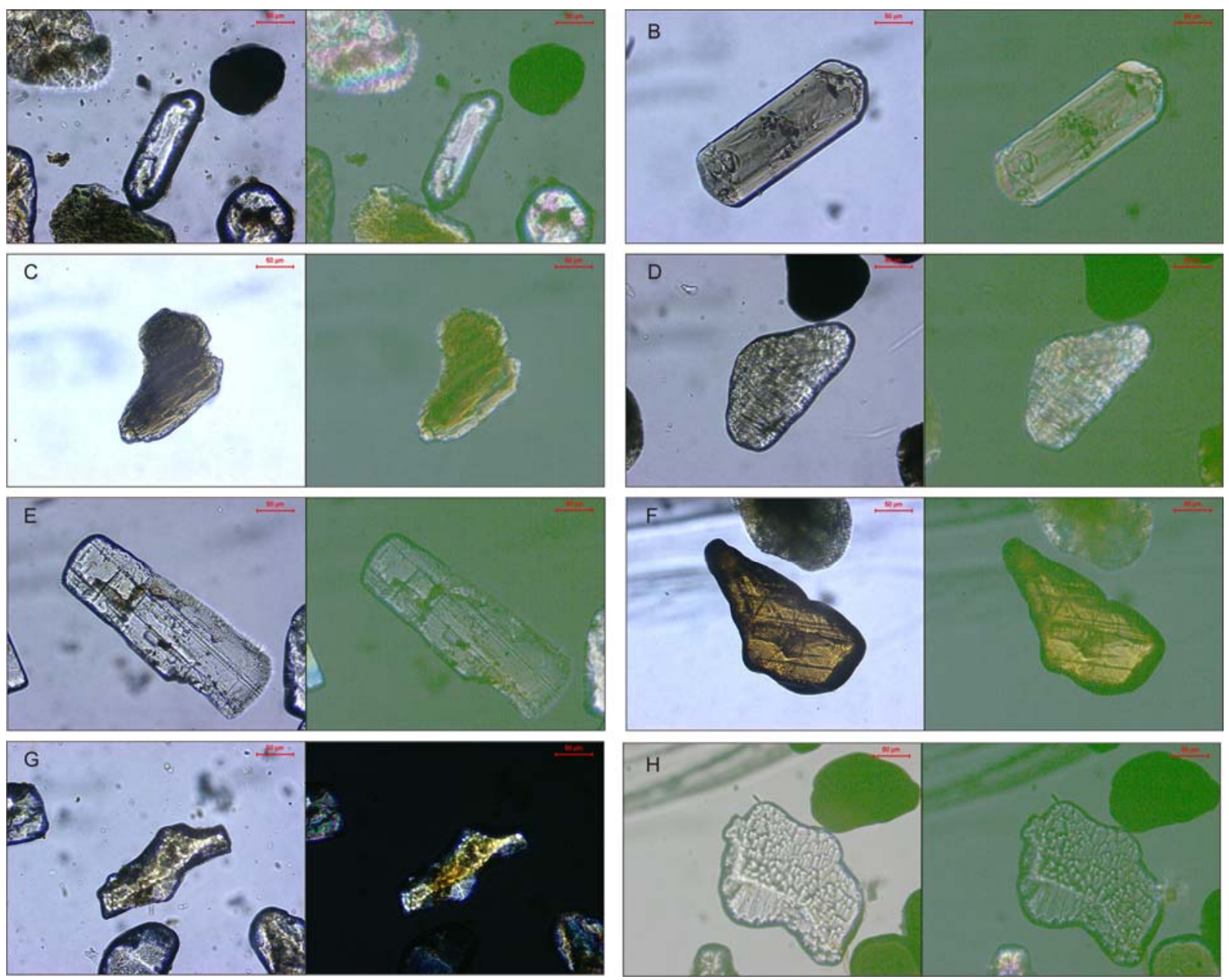

Figura 6.20 - Aspectos de alguns minerais pesados observados ao microscópio petrográfico, sob polarizadores paralelos e cruzados. A) Zircão prismático biterminado, subarredondado. B) Turmalina parda prismática, com inclusões no centro. C) Hornblenda parda avermelhada. D) Epídoto anédrico subarredondado. E) Cianita prismática. F) Rutilo avermelhado. G) Estaurolita geminada. H) Granada com crateramento.

Assim como para a planície de Campos Verdes, avaliou-se a variação transversal e em área dos índices de minerais pesados da planície do Ji. Quanto aos índices de maturidade mineralógica, ressalta-se a maior freqüência de componentes instavéis (iINS) e metaestáveis (iMET) em relação aos ultraestáveis (iZTR) na porção mais externa da planície, com tendência geral de queda de maturidade para $E$ (Fig.6.21A, 6.22A e 6.22B). Este padrão de variação espacial da mineralogia pode ser explicado pela concentração progressiva, por seleção hidráulica durante o retrabalhamento progradacional, de minerais pesados relativamente menos densos, na sua maioria instáveis, combinada à entrada de sedimentos novos transportados pelo rio que corta a planície e à menor atuação da dissolução pósdeposicional (com seu efeito de eliminação preferencial de minerais instáveis) na parte leste (mais nova) da planície. O aumento do iTZ rumo E (Fig.6.21B e 6.22C) reforça a hipótese de controle hidráulico na variação espacial da mineralogia. Já o aumento do iHT para $E$ (Fig.6.21C e 6.22D) é coerente com a hipótese de maior aporte de sedimentos ricos em hornblenda e/ou menor tempo de atuação da dissolução pós-deposicional, com menor 
eliminação química de hornblenda, na porção leste da planície. Este aumento não apresenta, todavia, distribuição uniforme, em contrate ao aumento de iTZ que, além de mais contínuo, exibe magnitudes de variação maiores (de 0,3 a 0,75). Desse modo, avalia-se que a primeira hipótese pode ser mais plausível, ou seja, o fator hidráulico representaria controle mais efetivo sobre a distribuição de minerais pesados na planície do Ji.

Quanto à variação de atributos mineralógicos em perfil longitudinal ao cordão, tem-se aumento de ilNS em detrimento do iZTR na porção nordeste da planície (Fig.6.21A, 6.22A e 6.22B), acompanhado de incremento nas razões iTZ e iHT (Fig.6.21B, 6.21C, 6.22C e 6.22D). Essa combinação de variações, admitida a hipótese de controle hidráulico numa mesma linha de tempo, pode ser interpretada como reflexo de paleoderiva litorânea dirigida para NE, com transporte preferencial de componentes menos densos nesse rumo.
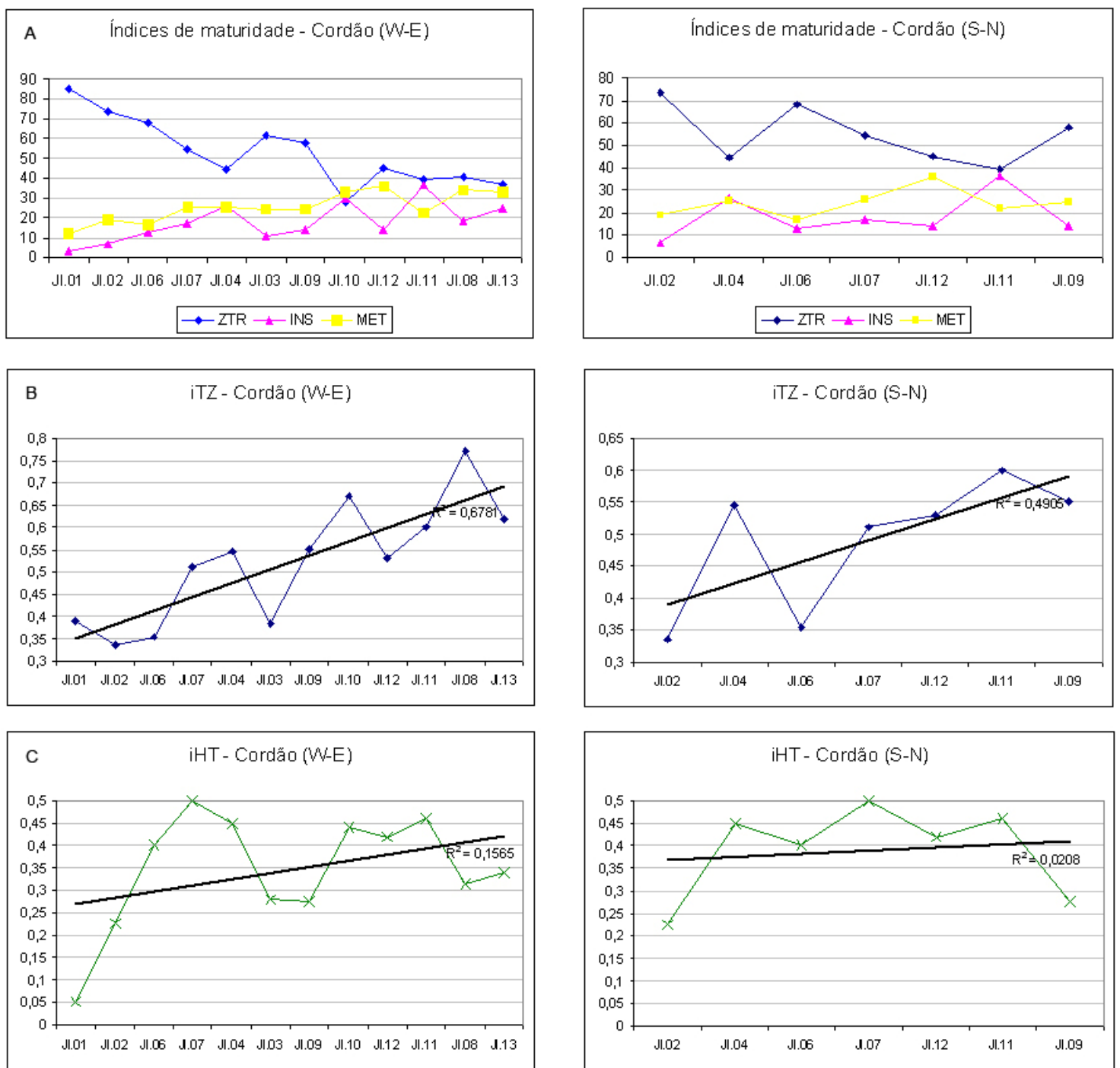

Figura 6.21 - Variação dos índices de minerais pesados da fração areia muito fina, ao longo de perfil transversal, de W para E, e longitudinal, de S para N, na planície do Ji. A) Variação dos índices de maturidade. B) Variação do iTZ. C) Variação do iHT. 
A

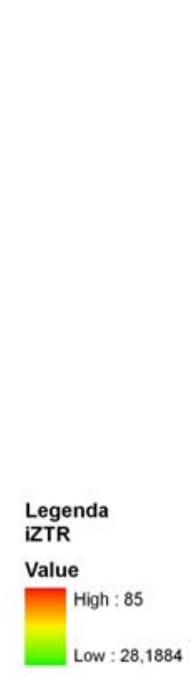

C

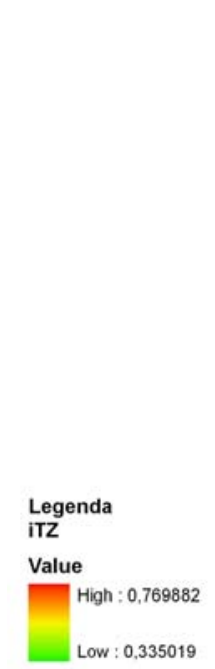

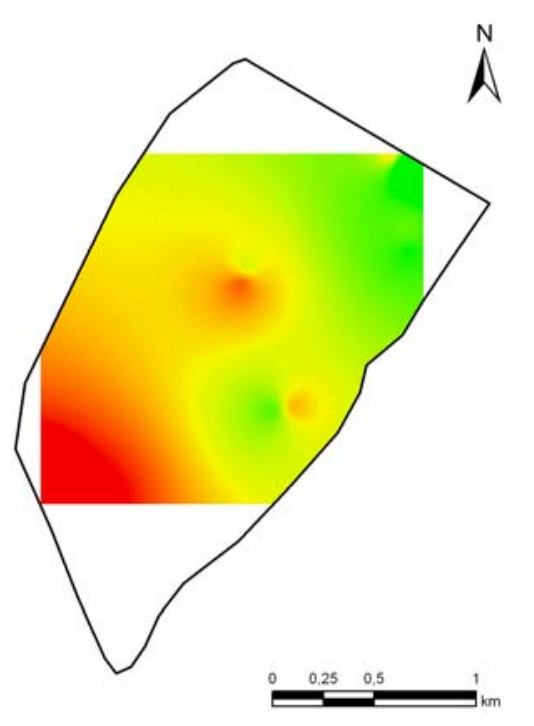

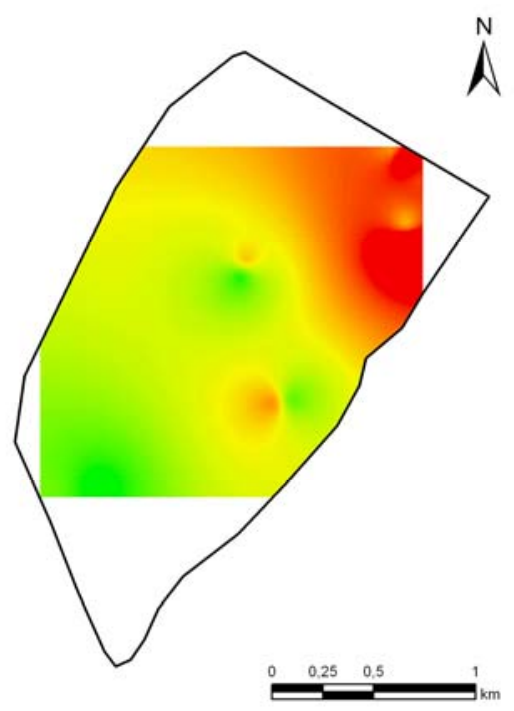

B

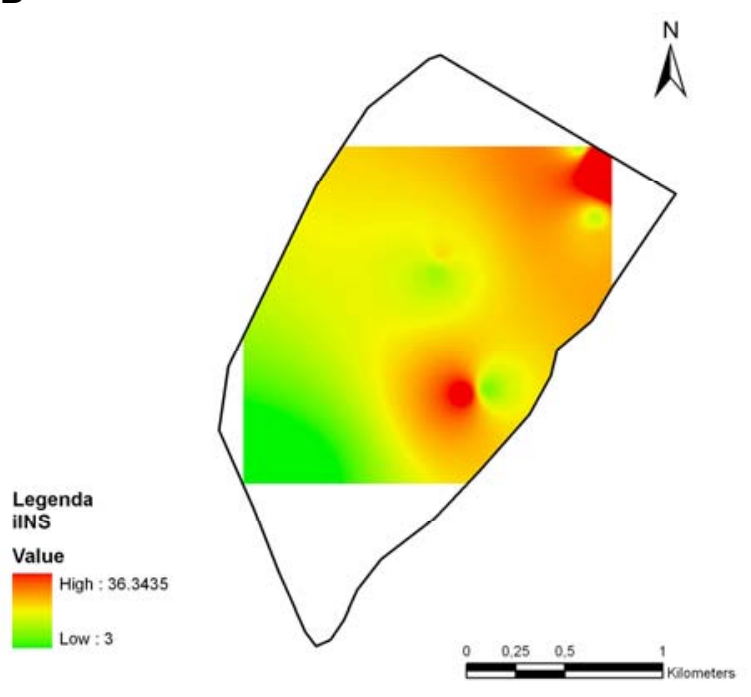

D
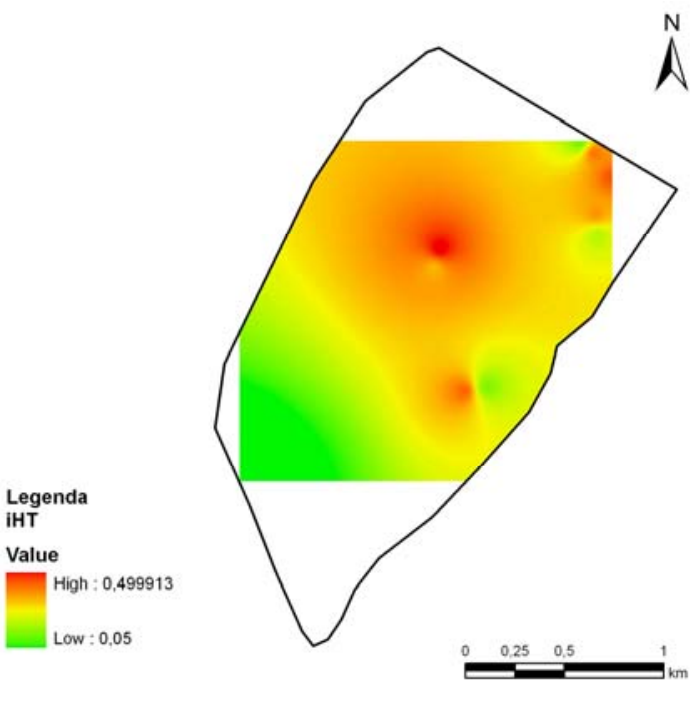

Figura 6.22 - Variação espacial de índices de minerais pesados da fração areia muito fina na planície do Ji: A) iZTR. B) ilNS. C) iTZ. D) iHT. Valores mais altos estão representados por cores mais quentes (vermelho).

\subsubsection{Mineralogia (Campos Verdes vs. Ji)}

Para comparar as características mineralógicas dos sedimentos de Campos Verdes e do Ji, foram construídos, para cada categoria faciológica, boxplots das seguintes variáveis: índice de ultraestáveis (clrZTR), índice de instáveis (clrINS), índice de metaestáveis (MET) e índices de controle iTZ, iHT e iRZ (Fig.6.23). Os índices foram transformados em sua razão log central (centered-log-ratio, clr) por se tratar de dados composicionais.

A variação entre valores obtidos para fácies diferentes da mesma planície é menor do que a variação observada para a mesma fácies em planícies diferentes. Esta observação permite concluir que os índices de minerais pesados neste estudo de caso são mais sensíveis a fatores de controle geográfico que faciológico. Somente o iRZ apresenta forte 
sobreposição entre as duas planícies, com valores médios ao redor de 0,2. Essa semelhança pode entretanto estar relacionada à baixa freqüência de rutilo nos sedimentos estudados, o que compromete a precisão do índice. No geral, os sedimentos da planície do Ji são mais imaturos mineralogicamente que os de Campos Verdes (clrINS mais elevado e clrZTR mais baixo).

Estando o iTZ ligado ao controle hidráulico, a diferença nos valores deste índice entre as planícies de Campos Verdes e Ji pode relacionar-se ao contraste entre elas nas condições de transporte e retrabalhamento, ligado a seus contextos hidrodinâmicos protegido versus de mar aberto, respectivamente. Já a sobreposição na variação no iHT pode indicar influência comum do rio Tubarão, como fonte de aporte sedimentar.

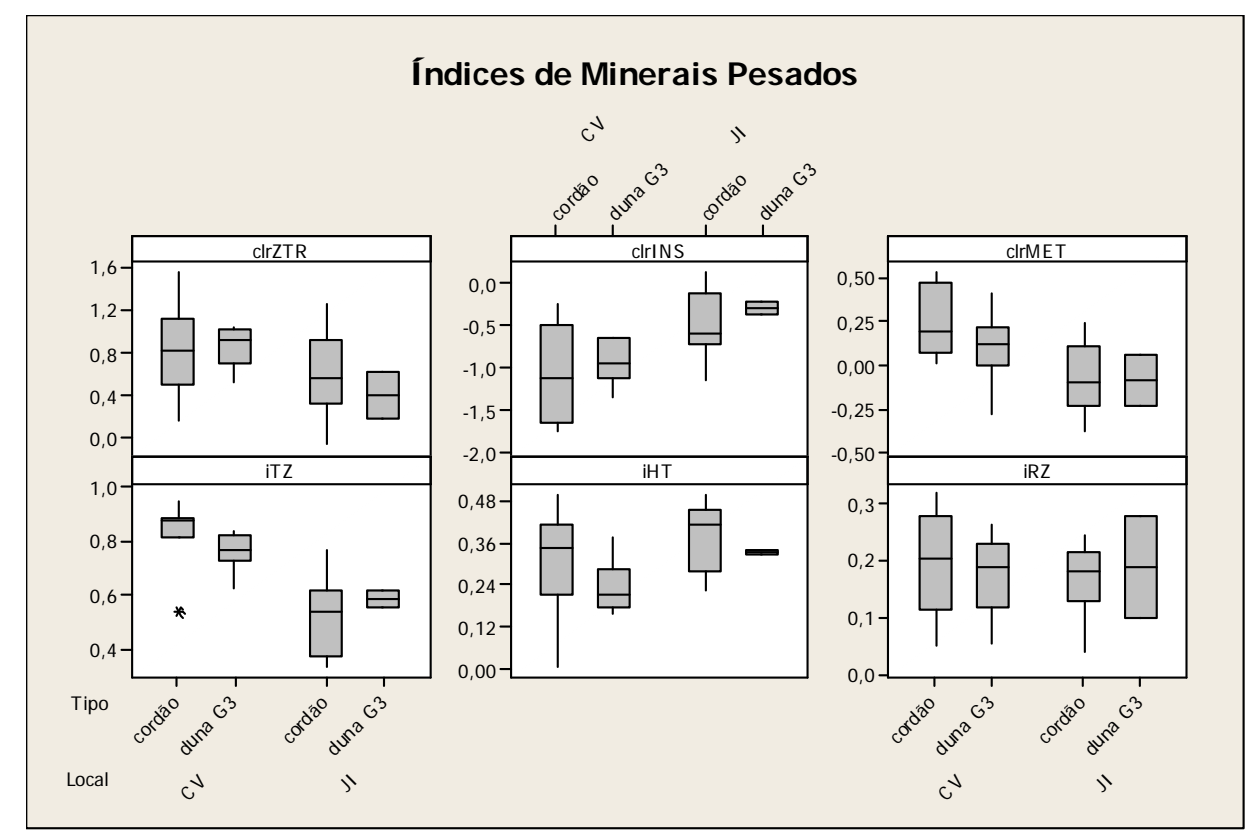

Figura 6.23 - Boxplots dos índices de minerais pesados, para amostras de dunas e cordões das planícies de Campos Verdes e Ji

A matriz de correlação dos índices clrINS, iHT e iTZ (Fig.6.24) ilustra diferenças entre os controles da assembléia mineralógica de uma planície para outra, sendo possível delimitar duas nuvens de pontos, uma para cada local, principalmente quando se relaciona clrINS-iTZ e iTZ-iHT. 


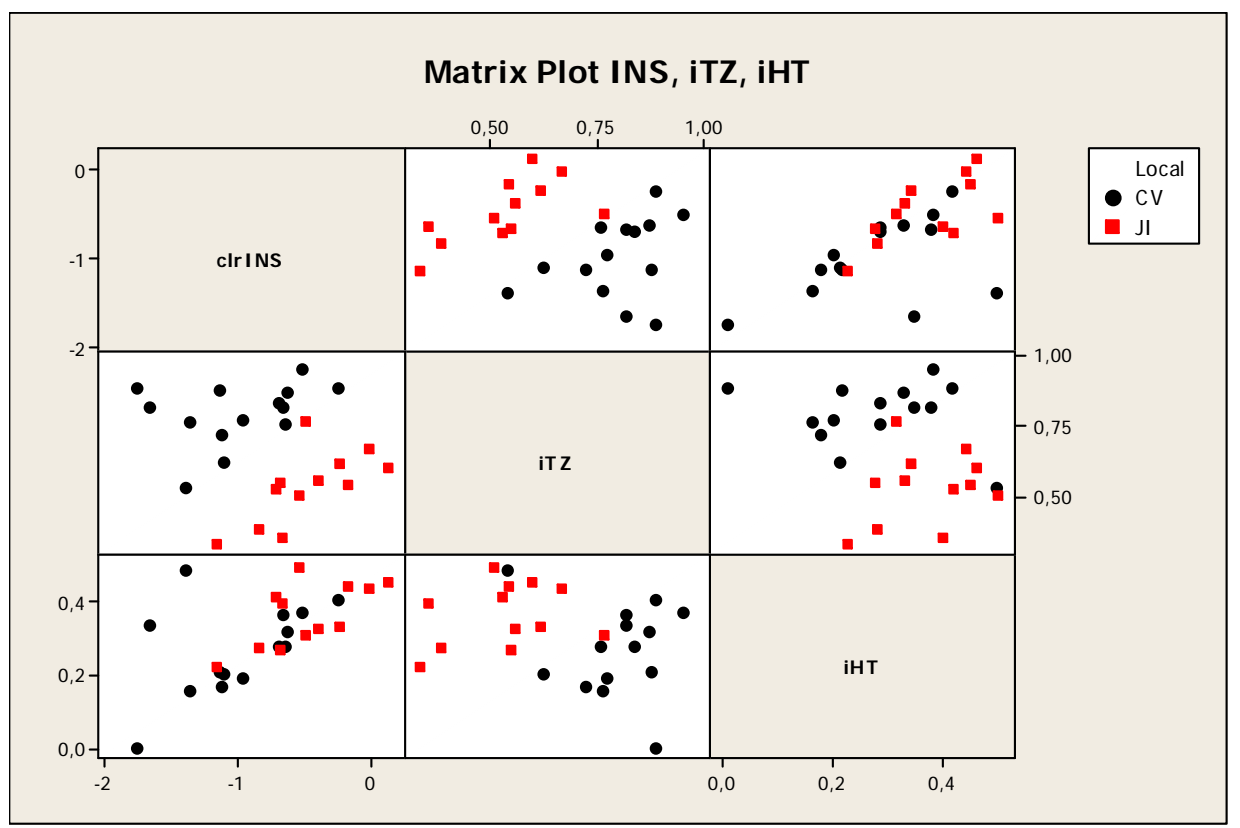

Figura 6.24 - Matriz de correlação entre os índices de minerais pesados (iHT, iTZ e clrINS) para amostras de dunas e cordões das planícies de Campos Verdes e Ji

\subsection{Controle da distribuição granulométrica e mineralógica}

Foi construída uma matriz de correlação entre os parâmetros estatísticos granulométricos de diâmetro médio (DM), desvio padrão (DP) e assimetria (AS), índices mineralógicos como hornblenda-turmalina ( $\mathrm{iHT}$ ), minerais instáveis (clrINS) e minerais ultraestáveis (clrZTR), e idades das amostras de cordão e duna de ambas as planícies (Tab.6.3). Os resultados indicam a existência de correlações significativas entre diversos pares de variáveis (destacados em negrito), sendo que as correlações mais fortes (valores do coeficiente de correlação > 0,5) ocorrem entre: DM e DP, DP e AS, clrINS e iHT, clrZTR e iHT, clrZTR e clrINS, idade e clrINS e idade e clrZTR.

Tabela 6.3 - Matriz de correlação entre variáveis granulométricas e mineralógicas dos sedimentos de cordão litorâneo e duna eólica de Campos Verdes e do Ji

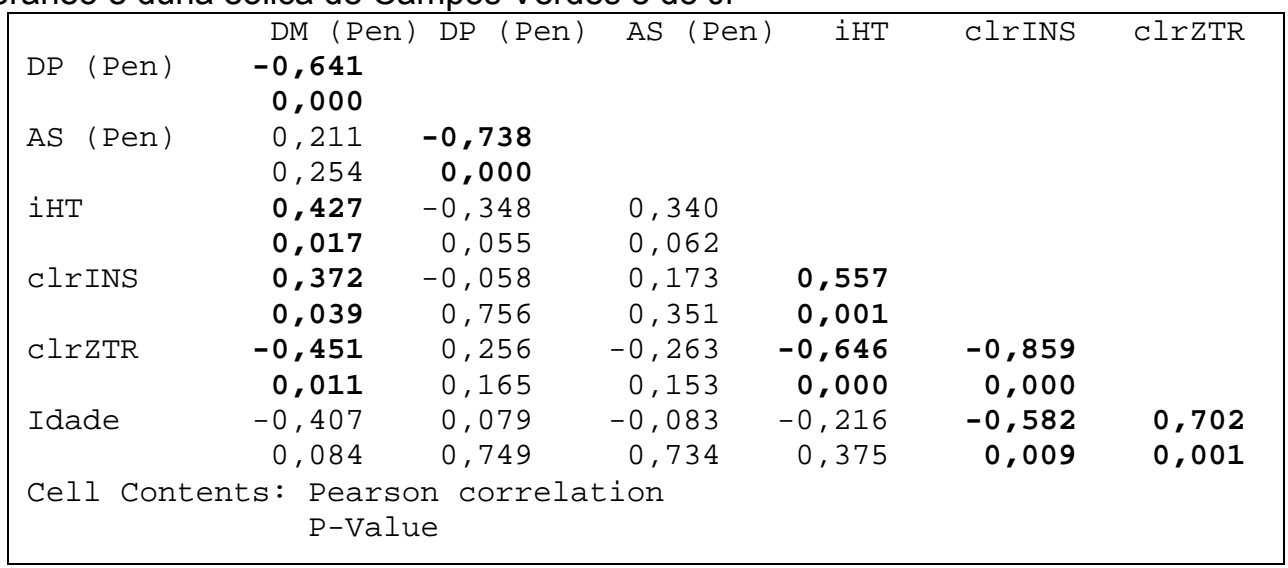


DM e DP apresentam correlação negativa para valores na escala phi (Fig.6.25), ou seja, quanto mais fino, melhor selecionado é o sedimento. A correlação negativa entre AS e DP significa que quanto mais assimétrico, melhor selecionado é o sedimento.

A variável granulométrica DM não apresenta correlações significativas $(p<0,05)$ com as variáveis mineralógicas. O coeficiente mais próximo de 0,5 ocorre entre DM e cIrZTR, sugestivo de relação entre tamanho dos grãos e concentração de minerais ultraestáveis. De acordo com esta relação, quanto mais fino o sedimento, menor é o clrZTR (Fig.6.25). Partindo-se da premissa de que a turmalina é o mineral ultraestável mais abundante nas amostras, e dado o baixo equivalente hidráulico deste mineral, então a correlação encontrada representa possivelmente evidência de seleção hidráulica.

A correlação positiva entre clrINS e iHT (Fig.6.26A) significa que quanto maior a concentração de instáveis mais altos são os valores do iHT. Explica-se pelo fato de que a hornblenda é o constituinte principal da classe dos minerais instáveis nas assembléias estudadas. A correlação negativa de -0,646 entre iHT e clrZTR relaciona-se ao mesmo fato e também à complementaridade entre instáveis e ultraestáveis. Assim como clrZTR e clrINS, clrZTR e iHT apresentam correlação inversa elevada. A idade também condiciona a proporção entre minerais instáveis e ultraestáveis, seja por concentração de estáveis ao longo do tempo devido a dissolução dos instáveis, seja por transporte seletivo de minerais mais leves (geralmente, mais instáveis) durante o retrabalhamento ou por mudança de área fonte. Dessa maneira, a idade correlaciona-se negativamente com o clrINS e positivamente com o clrZTR (fig.6.26B).

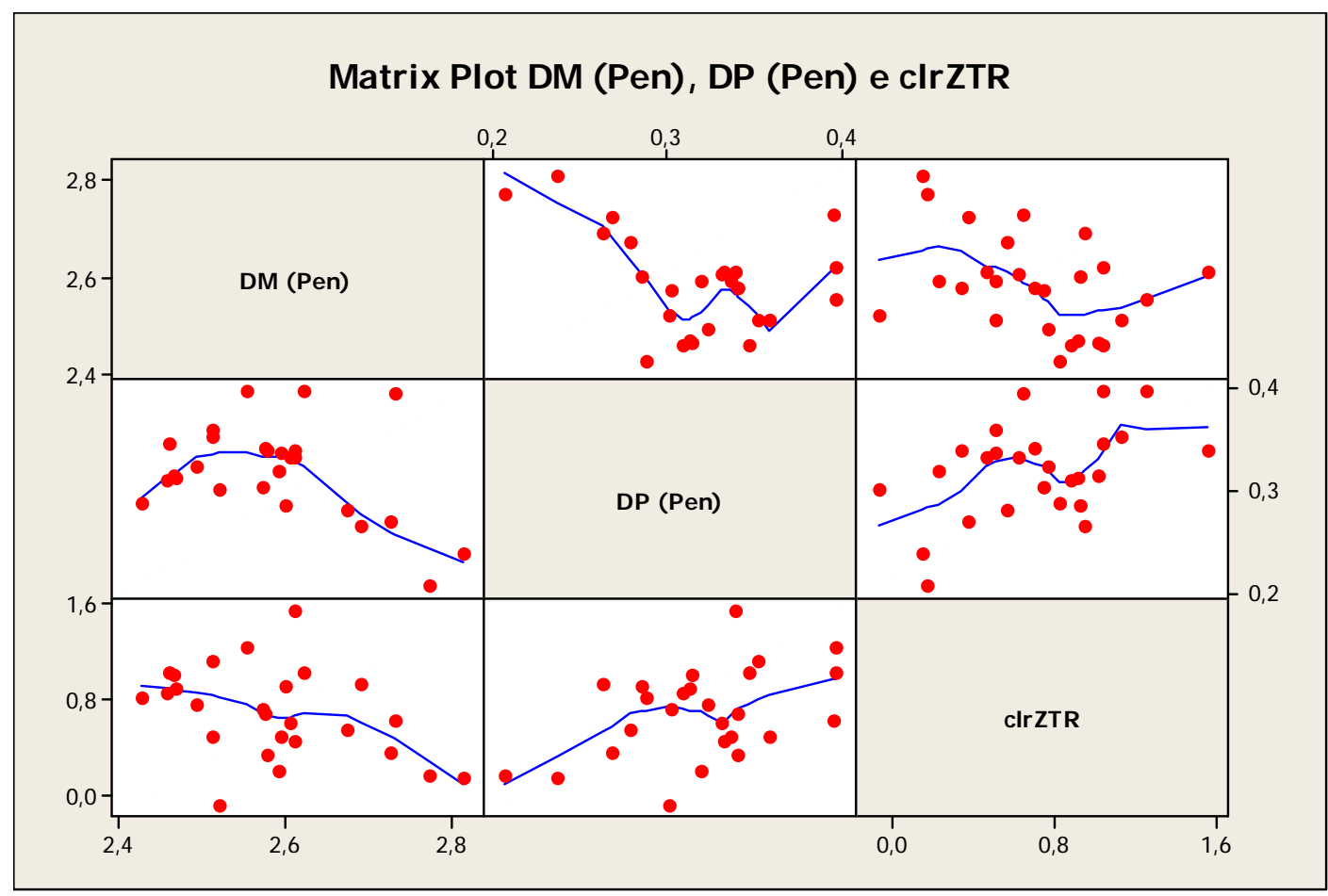

Figura 6.25 - Diagrama de dispersão em matriz (matrixplot) dos parâmetros granulométricos DM, DP e do índice mineralógico clrZTR. 

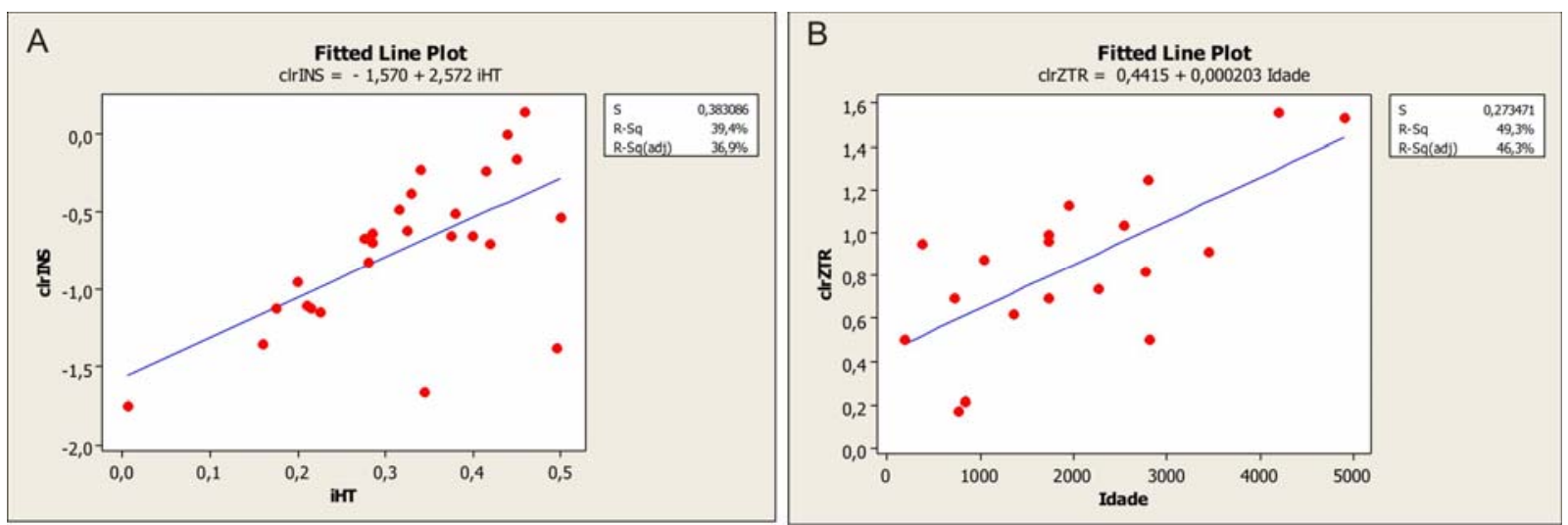

Figura 6.26 - Gráficos de regressão linear. A) Entre iHT e clrINS. B) Entre Idade e clrZTR.

Os valores das variáveis DM, DP, clrZTR, clrINS, iTZ, iRZ e iHT foram utilizados para construir cinco componentes principais (PC1, PC2, PC3, PC4 e PC5). Componentes principais são combinações lineares das variáveis utilizadas. A idéia é combinar o maior número possível de variáveis em um menor número possível de componentes, com menor perda de informação (Manly 1995). Essa combinação possibilita confrontar o problema relacionado à identificação e quantificação dos principais fatores que controlam a distribuição granulométrica e mineralógica em uma área restrita.

Para todas as amostras de cordões e dunas, as componentes principais PC1 e PC2, descritos pelas equações 6.1 e 6.2 , são responsáveis por $62,4 \%$ da variação (Tab.6.4):

$$
\begin{aligned}
& P C 1=-0,365 D M+0,274 D P+0,558 c|r Z T R-0,539 c| r I N S+0,021 \mathrm{iTZ}+0,010 \mathrm{iRZ}-0,436 \mathrm{iHT} \\
& P C 2=-0,349 D M+0,554 \mathrm{DP}-0,008 \mathrm{clrZTR}+0,172 \mathrm{clr} I N S-0,538 \mathrm{iTZ}+0,303 \mathrm{iRZ}+0,400 \mathrm{iHT}
\end{aligned}
$$

Tabela 6.4 - Valores obtidos na análise de componentes principais para todas as amostras de cordões litorâneos e dunas eólicas $(\mathrm{N}=26)$

Eigenanalysis of the Correlation Matrix

\begin{tabular}{lrrrrrrr} 
Eigenvalue & 2,825 & 1,538 & 1,360 & 0,546 & 0,385 & 0,298 & 0,049 \\
Proportion & 0,404 & 0,220 & 0,194 & 0,078 & 0,055 & 0,043 & 0,007 \\
Cumulative & 0,404 & 0,623 & 0,817 & 0,895 & 0,950 & 0,993 & 1,000 \\
Variable & PC1 & PC2 & PC3 & PC4 & & & \\
DM & $-0,365$ & $-0,349$ & 0,398 & 0,264 & & \\
DP & 0,274 & 0,554 & 0,158 & 0,664 & & \\
clrZTR & 0,558 & $-0,008$ & 0,183 & $-0,019$ & & \\
clrINS & $-0,539$ & 0,172 & $-0,091$ & $-0,053$ & & \\
iTZ & 0,021 & $-0,538$ & $-0,485$ & 0,635 & & \\
iRZ & 0,010 & 0,303 & $-0,731$ & $-0,106$ & & \\
iHT & $-0,436$ & 0,400 & 0,074 & 0,267 & & \\
\hline
\end{tabular}

As variáveis clrZTR e clrINS possuem os maiores pesos na PC1 (Eq.6.1). Já na PC2 (Eq.6.2), os maiores pesos são atribuídos às variáveis DP e iTZ. Desse modo, é possível dizer que as distribuições são caracterizadas principalmente pelo conteúdo de minerais 
pesados ultraestáveis, e, consequentemente, de instáveis, além de grau de seleção e razão turmalina/turmalina e zircão (Fig.6.27).

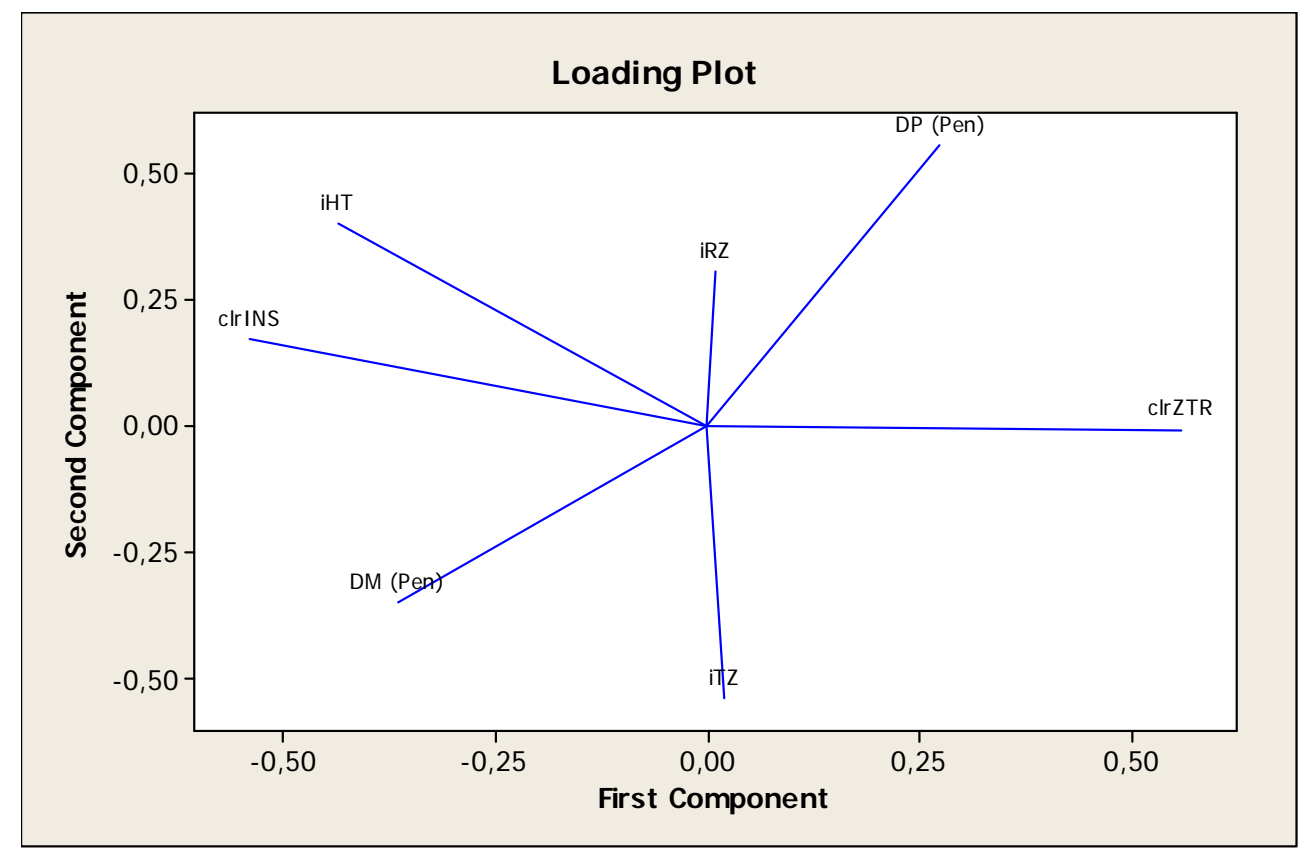

Figura 6.27 - Gráfico da PC1 pela PC2 para amostras de cordões e dunas.

Na Figura 6.28, observam-se dois campos principais de influência das variáveis na distribuição dos scores categorizados, um quadrante sudeste e um quadrante noroeste. $O$ quadrante sudeste contém as amostras de Campos Verdes e apresenta-se fortemente condicionado a valores mais altos de clrZTR e iTZ. O quadrante noroeste agrupa os pontos do Ji e mostra-se fortemente condicionado a valores maiores da variável mineralógica clrINS e, decorrentemente, de iHT.

Constata-se novamente que as variáveis mineralógicas são mais sensíveis a fatores de controle local, ou seja, variam mais de uma planície para outra, enquanto as variáveis granulométricas são menos sensíveis a mudanças locais, por estarem mais condicionadas a algum fator regional ou pelo intenso retrabalhamento anterior e homogeneização granulométrica herdada da área fonte.

Os valores mais elevados de iTZ e clrZTR para Campos Verdes poderiam caracterizar maior retrabalhamento, com ação do controle hidráulico, visto que a turmalina, mineral mais abundante nas amostras que compõe maior parte do iZTR, tem tendência a se concentrar ao longo do transporte devido a sua baixa densidade. Já os altos valores de clrINS e iHT para a planície do Ji podem decorrer do fato de se tratar de sedimentos mais novos. Nessa hipótese, a ser verificada com as datações, o alto iHT pouca dissolução ao longo do tempo e/ou entrada de sedimentos novos ricos em hornblenda na porção mais recente da planície. 


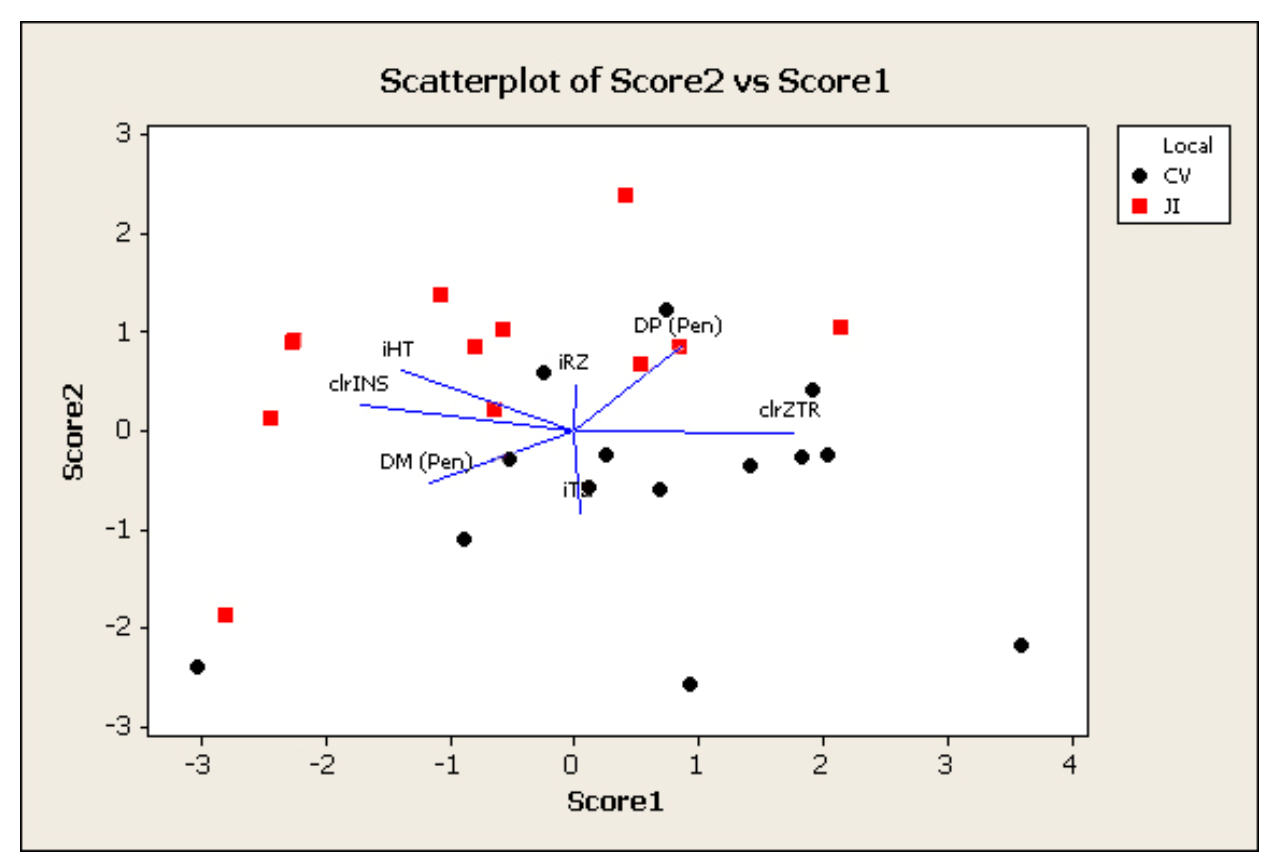

Figura 6.28 - Gráficos da PC1 pela PC2 com scores categorizados por local (Campos Verdes x Ji).

\subsection{Idades LOE e taxas de progradação}

A partir do método de datação LOE (protocolo SAR), foram obtidas 18 idades no total, sendo 12 para a planície de Campos Verdes e seis para a planície do Ji (Figs.6.29 a 6.31). As idades e os dados utilizados para o seu cálculo são apresentados na Tabela 6.5. Todas as idades encontram-se expressas em anos antes do presente (AP), sendo considerado "presente" a data de análise e obtenção das idades, 2008 para as amostras de Campos Verdes (exceto CV.18) e 2009 para as amostras do Ji mais a CV.18.

A idade mais antiga foi de $4912 \pm 270$ anos, para amostra de paleopontal arenoso, e a mais nova de $174 \pm 14$ anos, para paleoduna eólica ambas em Campos Verdes (Figs.6.29 e 6.31). Para as amostras da planície do $\mathrm{Ji}$, o intervalo de idades é mais restrito e mais novo que o dos cordões de Campos Verdes, com idade mais antiga de $2794 \pm 151$ anos, obtida em cordão litorânea, e mais recente de $751 \pm 43$ anos, obtida em paleoduna eólica (Figs.6.30 e 6.31).

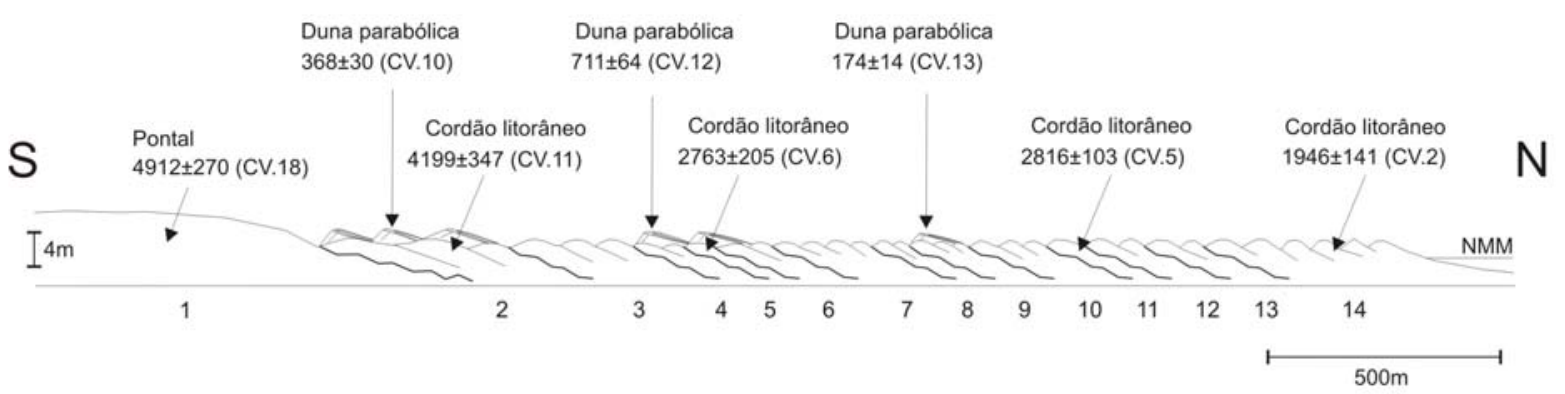

Figura 6.29 - Seção esquemática transversal aos cordões da planície de Campos Verdes, com distribuição de idades LOE. Cada série de cordões/clinoformas (de 1 a 14) é separada por truncamento. 


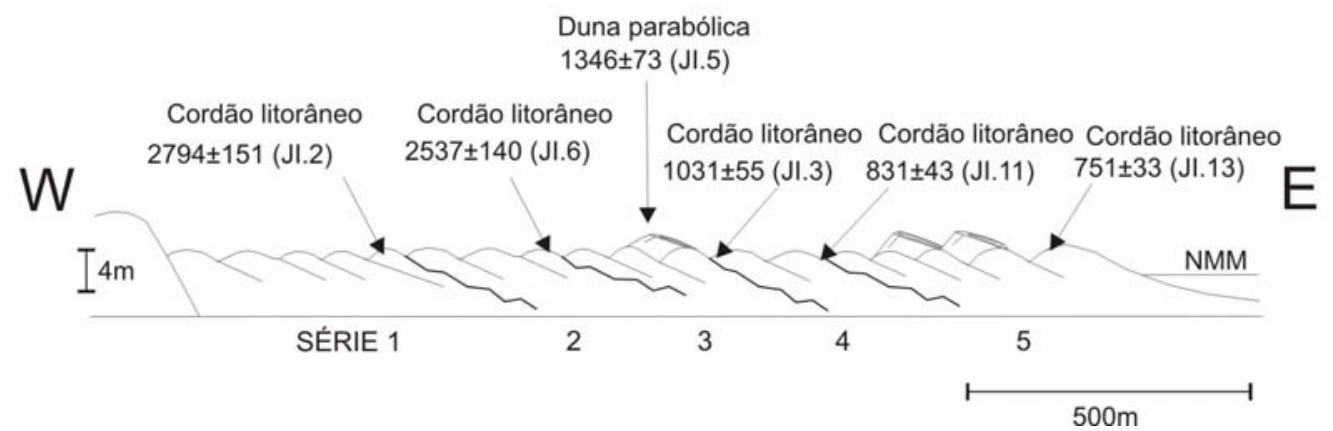

Figura 6.30 - Seção esquemática transversal aos cordões da planície do Ji, com distribuição de idades LOE. Cada série de cordões/clinoformas (de 1 a 5) é separada por truncamento.

Tabela 6.5 - Concentração de tório (Th), urânio $(U)$ e potássio $(K)$, taxas de doses e idades obtidas pelo método LOE para amostras das planícies de Campos Verdes e Ji

\begin{tabular}{|c|c|c|c|c|c|c|c|c|c|}
\hline ostra & 11 & $U$ & 6) & $\begin{array}{c}\text { Taxa de } \\
\text { dose } \\
\text { cósmica } \\
\text { (mGy/a) }\end{array}$ & $\begin{array}{c}\text { Taxa de } \\
\text { dose beta } \\
\text { (mGy/a) }\end{array}$ & $\begin{array}{r}\text { Taxe } \\
\text { dose } \\
\text { (mG }\end{array}$ & $\begin{array}{r}\text { Taxe } \\
\text { dose } \\
\text { (mG }\end{array}$ & $\begin{array}{l}\text { Dose } \\
\text { total } \\
\text { (Gy) }\end{array}$ & Ida \\
\hline & & & $\begin{array}{r}0,36 \\
0,0 \\
\end{array}$ & & & & & & $\begin{array}{c}1946 \pm \\
141 \\
\end{array}$ \\
\hline-00 & 0 & \pm & $\begin{array}{r}0,4 \varepsilon \\
0,0 \\
\end{array}$ & & & & & & $\begin{array}{c}2816 \pm \\
193 \\
\end{array}$ \\
\hline 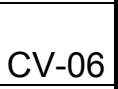 & & & & & & & & & $\begin{array}{c}2763 \pm \\
205 \\
\end{array}$ \\
\hline & & & & & & & & & $\begin{array}{c}3453 \pm \\
277\end{array}$ \\
\hline-08 & & & & & & & & & $\begin{array}{c}2255 \pm \\
123 \\
\end{array}$ \\
\hline & & & & & & & & & \begin{tabular}{|c|}
$368 \pm$ \\
30 \\
\end{tabular} \\
\hline & & & & & & & & & $\begin{array}{c}4199 \pm \\
347\end{array}$ \\
\hline & & & & & & & & & $\begin{array}{c}711 \pm \\
64\end{array}$ \\
\hline & & & & & & & & & $\begin{array}{c}174 \pm \\
14 \\
\end{array}$ \\
\hline & & & & & & & & & $\begin{array}{c}1723 \pm \\
119 \\
\end{array}$ \\
\hline & & & & & & & & & $\begin{array}{c}355 \pm \\
50 \\
\end{array}$ \\
\hline & & & & & & & & & $\begin{array}{c}4912 \pm \\
270\end{array}$ \\
\hline & & & & & & & & & $\begin{array}{r}2794 \pm \\
151 \\
\end{array}$ \\
\hline & & & & & & & & & $\begin{array}{c}1031 \pm \\
55 \\
\end{array}$ \\
\hline & & & & & & & & & $\begin{array}{c}1346 \pm \\
73\end{array}$ \\
\hline & & & & & & & & & $\begin{array}{c}2537 \pm \\
140\end{array}$ \\
\hline & & & & & & & & \begin{tabular}{|c|}
$0,450 \pm$ \\
0,020
\end{tabular} & $\begin{array}{c}831 \pm \\
43\end{array}$ \\
\hline & & & & & & & & $\begin{array}{c}0,411 \pm \\
0,021 \\
\end{array}$ & $\begin{array}{c}751 \pm \\
43 \\
\end{array}$ \\
\hline
\end{tabular}




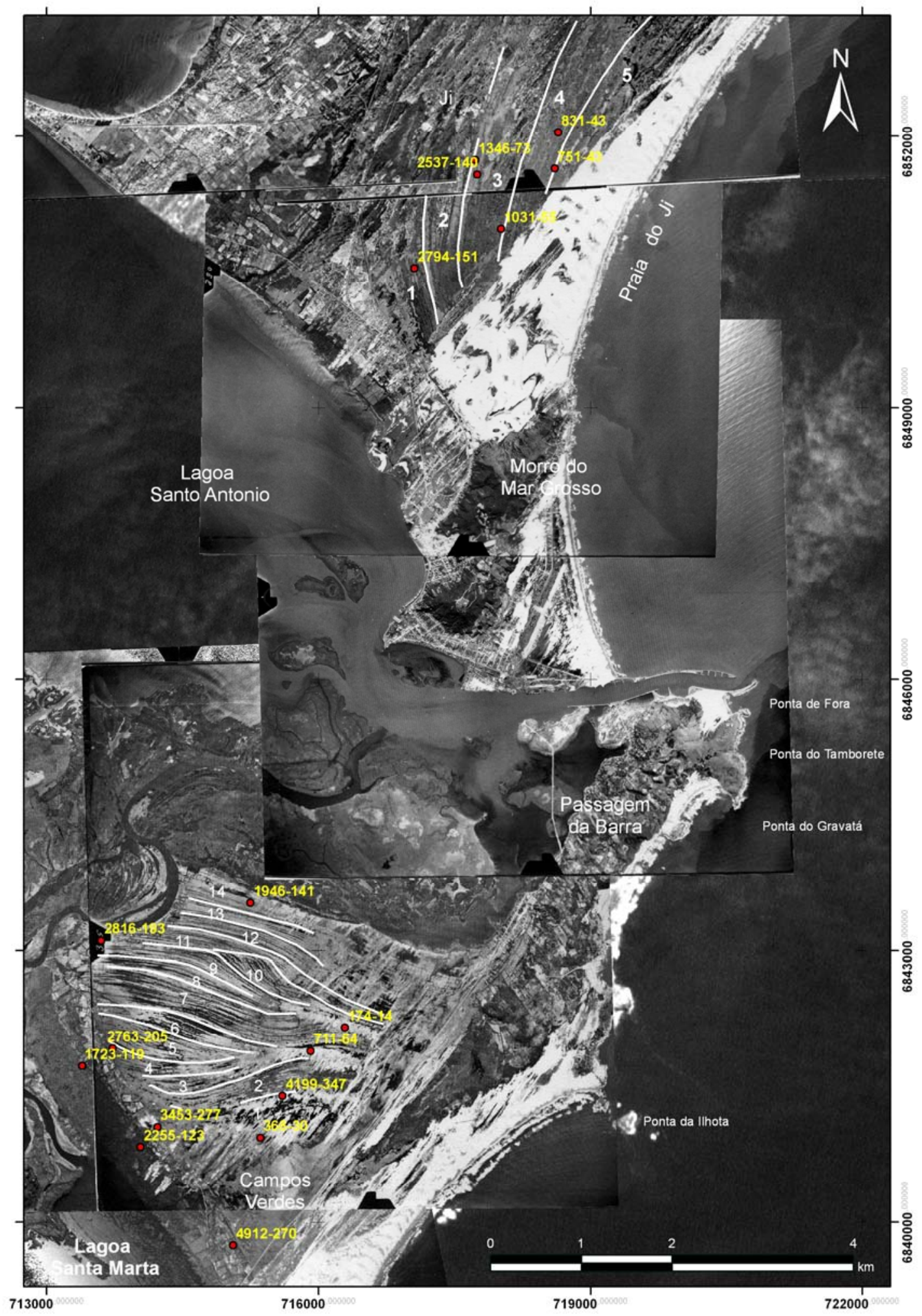

Figura 6.31 - Localização das amostras datadas, e respectivas idades em anos AP, com a delimitação dos feixes numerados de 1 a 5 para a planície do Ji (oeste para leste) e de 1 a 14 para a planície de Campos Verdes (sul para norte) 
As taxas de progradação calculadas para as planícies de Campos Verdes e do Ji são apresentadas na Tabela 6.6. As variações das taxas de progradação ao longo do tempo foram representadas através de gráficos de idade (anos) por distância $(\mathrm{m})$ transversal à planície de cordões (Fig.6.32).

Tabela 6.6 - Estágios de evolução nas duas planícies, com respectivos pontos datados, feição morfológica ou série de cordão correspondente, distância entre séries $(\mathrm{m})$, intervalo de tempo envolvido (anos) e taxas de progradação mínimas e médias (m/ano).

\begin{tabular}{|c|c|c|c|c|c|c|}
\hline \multirow{2}{*}{ Estágio } & \multirow{2}{*}{ Amostra } & \multirow{2}{*}{ Série } & \multirow{2}{*}{$\begin{array}{l}\text { Distância } \\
(\mathrm{m})\end{array}$} & \multirow{2}{*}{$\begin{array}{l}\text { Intervalo de tempo } \\
\text { (anos) }\end{array}$} & \multicolumn{2}{|c|}{ Taxas de progradação } \\
\hline & & & & & $\min (\mathrm{m} / \mathrm{ano})$ & med (m/ano) \\
\hline (CV) 1 & CV.18-CV.07 & Pontal & 1560 & $4912 \pm 270$ a $3453 \pm 277$ & 0,78 & 1,07 \\
\hline (CV) 1 & CV.18-CV.11 & Pontal & 1740 & $4912 \pm 270$ a $4199 \pm 347$ & 1,31 & 2,44 \\
\hline$(\mathrm{CV}) 2$ & CV.11-CV.06 & 1 a 4 & 500 & $4199 \pm 347$ a $2763 \pm 205$ & 0,25 & 0,35 \\
\hline$(\mathrm{CV}) 3$ & CV.06-CV.05 & 5 a 10 & 1190 & $2763 \pm 205$ a $2816 \pm 193$ & 3,45 & - \\
\hline$(\mathrm{CV}) 4$ & CV.05-CV.02 & 11a 14 & 662 & $2816 \pm 193$ a $1946 \pm 141$ & 0,55 & 0,76 \\
\hline$(\mathrm{CV}) 5$ & CV.02 - atual & - & - & $1946 \pm 141$ a 52 & - & - \\
\hline (JI) 1 & Jl.02 & 1 & 580 & (?) a $2794 \pm 151$ & - & - \\
\hline (JI) 2 & JI.02 - Jl.06 & 2 & 420 & $2794 \pm 151$ a $2537 \pm 140$ & 1,06 & 2,26 \\
\hline (JI) 3 & JI.06 - Jl.03 & 3 & 293 & $2537 \pm 140$ a $1031 \pm 55$ & 0,25 & 0,28 \\
\hline (JI) 4 & JI.03 - Jl.11 & 4 & 900 & $1031 \pm 55$ a $831 \pm 43$ & 0,98 & 1,47 \\
\hline (JI) 5 & JI.13 - atual & 5 & 870 & $751 \pm 43$ a 52 & 1,17 & 1,24 \\
\hline
\end{tabular}

\subsubsection{Estágios cronológicos de Campos Verdes}

A evolução de Campos Verdes pode ser dividida em cinco estágios cronológicos:

Estágio 1) Início do crescimento do pontal arenoso. A datação obtida em CV.18 indica que em $4912 \pm 270$ anos, o pontal já existia. Entre esta data e $3453 \pm 30$ anos (CV.07), a feição morfológica desenvolveu-se rumo NW, sincronicamente à formação dos primeiros cordões litorâneos (início do estágio 2). O crescimento longitudinal do pontal rumo NW deu-se com taxa média de $1,07 \mathrm{~m} /$ ano enquanto seu crescimento lateral rumo ao interior da laguna, ocorreu entre $4912 \pm 270$ anos (CV.18) e 4199 \pm 347 anos (CV.11), à taxa média de 2,44 m/ano.

Estágio 2) Desenvolvimento das primeiras séries de cordões litorâneos (séries 1 a 4), localizadas na porção sul da planície. Este estágio teve início após $4199 \pm 347$ anos (CV.11) e terminou em $2763 \pm 205$ anos (CV.06). A taxa média de progradação foi de 0,35 m/ano.

Estágio 3) Crescimento das séries centrais de cordões litorâneos (séries 5 a 10) com

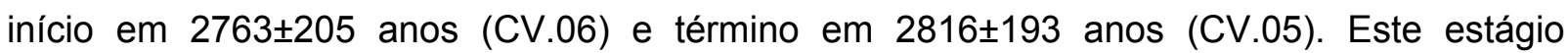
apresenta cordões litorâneos formados em um intervalo de tempo inferior às incertezas obtidas para as idades LOE. Desse modo, foi possível calcular apenas a taxa mínima de progradação: 3,45 m/ano. 
Estágio 4) Formação dos cordões litorâneos (séries 11 a 14) na porção norte da planície, com início em $2816 \pm 193$ anos (CV.05) e fim em $1946 \pm 141$ anos (CV.02). Neste estágio final de desenvolvimento de cordões, a taxa média de progradação foi de 0,76 m/ano. A idade mais antiga obtida para paleodunas eólicas em ambas as planícies, $2255 \pm 123$ anos (CV.08), encontra-se compreendida nesta fase evolutiva da planície de Campos Verdes. Corresponde a paleodunas parabólicas com lobos deposicionais bem desenvolvidas (espessura métrica).

Estágio 5) Desenvolvimento das últimas séries de cordões litorâneos no extremo norte da planície, entre $1946 \pm 141$ anos (CV.02) e o presente. A taxa de progradação média não foi calculada devido a erosão (falta de registro) das séries posteriores a série 14 , onde atualmente se encontram depósitos dos distributários do rio Tubarão. Durante este estágio ocorreram episódios de desenvolvimento/reativação de dunas com idades de $711 \pm 64$ anos (CV.12), 368 \pm 30 anos (CV.10), e 174 \pm 14 anos (CV.13). Estas três idades correspondem porém a dunas parabólicas delgadas (espessura decimétrica), cuja forma é sugestiva de forte componente deflacionar (alta relação energia eólica / aporte).

\subsubsection{Estágios cronológicos do Ji}

Foram definidos cinco estágios cronológicos de evolução sedimentar para a planície do Ji, correspondentes a cinco séries de cordões.

Estágio 1) Desenvolvimento da primeira série de cordões litorâneos, anterior a 2794₫151 anos (idade de Jl.02), ancorada no morro do Mar Grosso, no sul da planície.

Estágio 2) Crescimento da segunda série de cordões litorâneos, na porção sudoeste

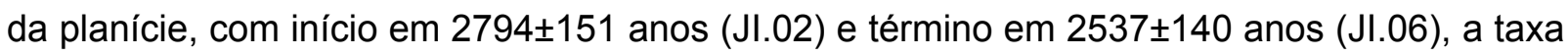
de progradação média de 2,26 m/ano.

Estágio 3) Desenvolvimento da série central de cordões litorâneos (série 3), entre $2537 \pm 140$ anos (JI.06) e 1031 \pm 35 anos (JI.03), com taxa de progradação média de 0,28 m/ano. Os cordões defletem da direção NNE para NE, durante este estágio.

Dunas da geração eólica 3 de Giannini et al. (2007) encontram-se sobre cordões da série 3. Os lobos deposicionais das paleodunas parabólicas apresentam idade de $1346 \pm 73$ anos (Jl.05). Portanto, a atividade destas dunas teria ocorrido entre $1346 \pm 73$ anos e $2537 \pm 140$ anos (idade do cordão por elas superposto). Esta seria a idade teórica máxima possível para a chegada das dunas na região. Logicamente, a idade de iniciação das dunas, na costa, pode e deve ser muito (vários séculos) mais nova que $2537 \pm 140$ anos e, analogamente, consideravelmente mais velha que $1346 \pm 73$ anos (uma vez que o lobo se encontra a quilômetros de distância da respectiva paleolinha de costa). 
Estágio 4) Formação dos cordões da série 4 com início em $1031 \pm 35$ anos (JI.03) e término em $831 \pm 43$ anos (JI.11). A taxa de progradação média calculada para o período é de $1,47 \mathrm{~m} / \mathrm{ano}$.

Estágio 5) Desenvolvimento de cordões litorâneos paralelos à atual linha de costa (série 5). Esta fase ocorreu desde 751 \pm 43 anos (JI.13) até 52 anos AP (ou 1956, data das fotos aérea utilizadas) e a taxa de progradação média foi calculada em 1,24 m/ano. Como estes cordões se encontram cobertos por campos de dunas transgressivos ainda ativos, correspondentes à geração eólica 4 de Giannini (1993) e Giannini et al. (2007), a idade encontrada seria também a máxima admissível para esta geração neste local.

\subsection{Dinâmica costeira e mudanças climáticas}

\subsubsection{Progradação dos cordões litorâneos}

A idade mais antiga encontrada nos cordões datados (4912 \pm 270 anos) sugere que a progradação costeira teve início no Holoceno médio (por volta de 5000 anos A.P). De acordo com os dados de NRM para a costa brasileira (Angulo et al. 2006), esse período situa-se no contexto de uma desaceleração do aumento do NRM, seguida do alcance do nível de mar máximo e de sua subseqüente queda. Esta condição favoreceu a superação da taxa de geração de espaço de acomodação pela taxa de aporte sedimentar e, portanto, a rápida progradação, durante o Holoceno tardio. O mesmo período de início do desenvolvimento da progradação costeira também é observado em outras planícies de cordões do hemisfério sul (Dominguez et al. 1983, Woodroffe et al. 1983, Roy et al. 1994, Angulo et al. 1996, Isla \& Bujalesky 2000, Lessa et al. 2000, Blivi et al. 2002, Giannini et al. 2003, Tomazelli \& Villwock 2005, Bristow et al. 2006, Fitzgerald et al. 2007, Brooke et al. 2008, Sawakuchi et al. 2008, Dias \& Kjerfve 2009, Angulo et al. 2009, Dillenburg et al. 2009, Giannini et al. 2009, Guedes 2009, Hesp et al. 2009).

A taxa de queda do NRM calculada (graficamente) com base na curva de variação do NRM, construída para a costa leste brasileira por Angulo et al. (2006), corresponde a cerca de $0,44 \mathrm{~m} / \mathrm{ka}$ para o período dos ultimos 5000 anos. Essa taxa pode ser considerada aproximadamente constante. Partindo da premissa de constância na taxa de queda de NRM no Holoceno médio, então intervalos de tempo com altas taxas de progradação seguidos por momentos de estabilização da linha de costa estariam relacionados somente a mudanças (variações) de aporte sedimentar.

Idades LOE obtidas para sedimentos ao longo do embaiamento holocênico de Guichen Bay, sul da Austrália (Murray-Wallace et al. 2002), são evidências de início de 
progradação costeira por volta de 4000 anos AP, com taxas aproximadamente constantes naquela região. Esse padrão de constância na taxa de progradação contrasta com o observado nas planícies de Campos Verdes e Ji, cuja regressão ocorreu em pulsos, com variação das taxas de progradação ao longo do tempo segundo padrão escalonado, que intercala fases de alta taxa de regressão com fases de relativa estabilização da linha de costa (Fig.6.32). Além disso, as variações entre as taxas de progradação de Campos Verdes ocorrem fora de fase em relação às do $\mathrm{Ji}$, com menores taxas em Campos Verdes contemporâneas a períodos de rápida progradação na planície do Ji e vice-versa. Em um único período, por volta de 2700 anos AP, registrou-se progradação simultânea em ambas as planícies, e a taxas maiores que nos demais estágios (ainda que com magnitude de taxa de progradação maior em Campos Verdes do que no Ji).
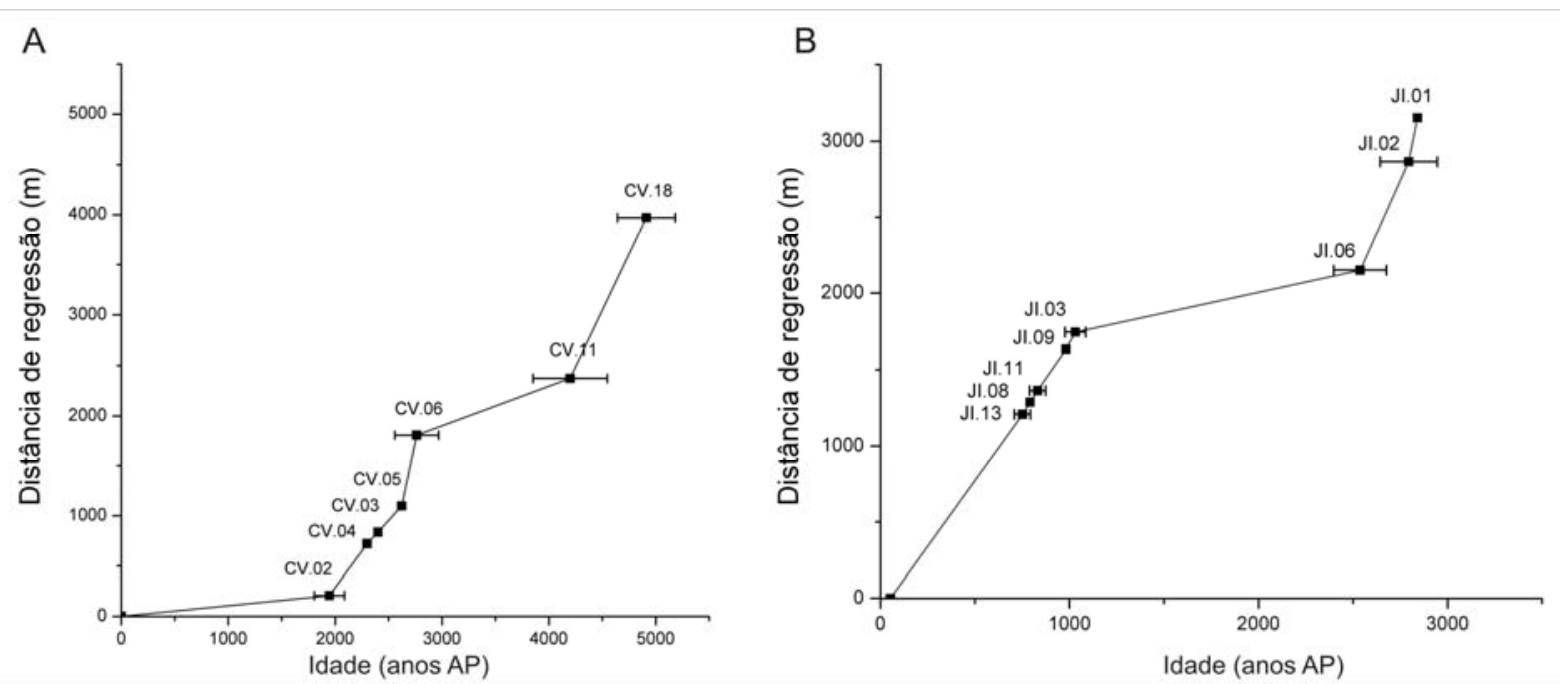

Figura 6.32 - Gráfico de distância de regressão em função da idade. A) Campos Verdes. B) Ji.

Desse modo, há três casos bem distintos no padrão de progradação das duas planícies, os dois primeiros com anti-fase entre elas, e a taxas progradacionais moderadas, e o terceiro com ambas as planícies progradando, em fase, a taxa mais elevada. De acordo com o gráfico de distância de regressão por idade (Fig.6.32), o caso 1, progradação favorecida no Ji, ocorre aproximadamente nos períodos entre 4200 e 2800 anos AP e entre 2000 anos AP e o atual; já o caso 2, progradação favorecida em Campos Verdes, registra-se no período entre 2600 e 2000 anos AP aproximadamente. Enquanto isso, o caso 3, com progradação acentuada (acima da média) em ambas as planícies, ocorre por volta de 2800 a 2600 anos AP.

A progradação das planícies de Campos Verdes e Ji em anti-fase estaria ligada à dinâmica de equilíbrio entre as duas desembocaduras lagunares da região, Camacho e Entrada da Barra, haja visto o papel das desembocaduras lagunares em geral no controle da pressão hidráulica de sistemas lagunares (Bruun 1987). Assim, pode-se admitir que quando o fluxo em dado rumo de ação da maré (enchente ou vazante) aumenta na desembocadura de 
Entrada da Barra, o mesmo fluxo diminui, ou mesmo se inverte, na desembocadura do Camacho, e vice-versa (Giannini 1993). Este comportamento anti-fásico seria acentuado pela diferença de orientação das duas desembocaduras da região: a desembocadura do Camacho, voltada para SE, seria mais propensa a enchente durante a ação de ondulações (swells) vindas desse quadrante, enquanto a de Entrada da Barra, voltada para E, receberia e confinaria preferenciamente os fluxos de enchente nos períodos de ação de ondas de $\mathrm{E} e$ NE. Com isso, a alternância na ação das duas desembocaduras seria acompanhada de mudanças no rumo de aporte sedimentar por deriva litorânea longitudinal.

De acordo com esse modelo, no caso 1 (progradação favorecida no Ji), que é mais comum ao longo do tempo, predominariam ondas de SE e deriva litorânea rumo NE, condição propiciada por incursões mais freqüentes e/ou mais intensas de frentes frias e massa de ar polar na região. Nestas condições, o fluxo de enchente ocorreria preferencialmente pelo canal do Camacho, com descarga (fluxo vazante) de águas e sedimentos por Entrada da Barra. Dado o controle do crescimento da planície de Campos Verdes pela entrada de sedimentos via desembocadura de Entrada da Barra, conforme demonstrado pela progradação rumo norte (Tanaka et al. 2009a), a perda de sedimentos por vazante nesta desembocadura desfavorece a progradação em Campos Verdes. Simultaneamente, favorece o aporte para mar aberto, redirecionado pela deriva litorânea longitudinal então voltada para NE, condição propícia para a progradação das praias a norte da desembocadura de Entrada da Barra, incluindo a planície do Ji.

No caso 2, inversamente, a dominância de ondas de NE e da deriva litorânea longitudinal rumo SW, propiciada pela maior ação da massa tropical Atlântica (com menos incursões de frentes frias), favoreceria o fluxo de enchente por Entrada da Barra e de vazante pelo canal Camacho. Favorece-se assim, por extensão, a retenção sedimentar e progradação da planície de Campos Verdes, em detrimento da do Ji. A inversão de deriva e a perda de aporte sedimentar e de taxa de progradação na planície do Ji resultam em erosão ou estabilidade da sua linha de costa, situação propícia para o desenvolvimento de dunas eólicas (Giannini et al. 2007). Há que se destacar que estas dunas migram para SW, portanto no rumo de vento normalmente associado à ação da massa tropical Atlântica, o que torna o presente modelo coerente também sob o aspecto do transporte eólico. Além disso, a idade mais antiga de duna eólica encontrada na planície do Ji (1346 \pm 73 anos) encontra-se sintomaticamente em período de estabilização ou baixa progradação da linha de costa nesta planície.

No terceiro caso, as taxas de progradação elevadas em ambas as planícies, por curto período de tempo, indicam a quebra momentânea do equilíbrio anti-fásico observado nos caso 1 e 2, possivelmente devido a evento de caráter regional, pontuado no tempo. Uma hipótese plausível para explicar a natureza deste evento seria o incremento da descarga 
sedimentar dos distributários do rio Tubarão, ligado a aumento marcante de precipitação/umidade. Tal hipótese é sustentada também por resultados de análise de minerais pesados, onde existe registro de aumento abrupto de iHT nesse período, ligado a mudança de fonte, com maior aporte de sedimentos ricos em hornblenda. No período em questão, observam-se maiores taxas de variação do iHT enquanto a variação do iTZ é suave (Fig.6.33). Isto sugere que o controle da distribuição de minerais pesados foi mais condicionada a mudança de fonte do que a seleção hidraúlica. Conforme já discutido nos resultados de pesados, o aumento de iHT pode ser indício de maior influência do aporte do rio Tubarão, o que, do ponto de vista climático, pode corresponder a maior precipitação na bacia de captação deste rio.
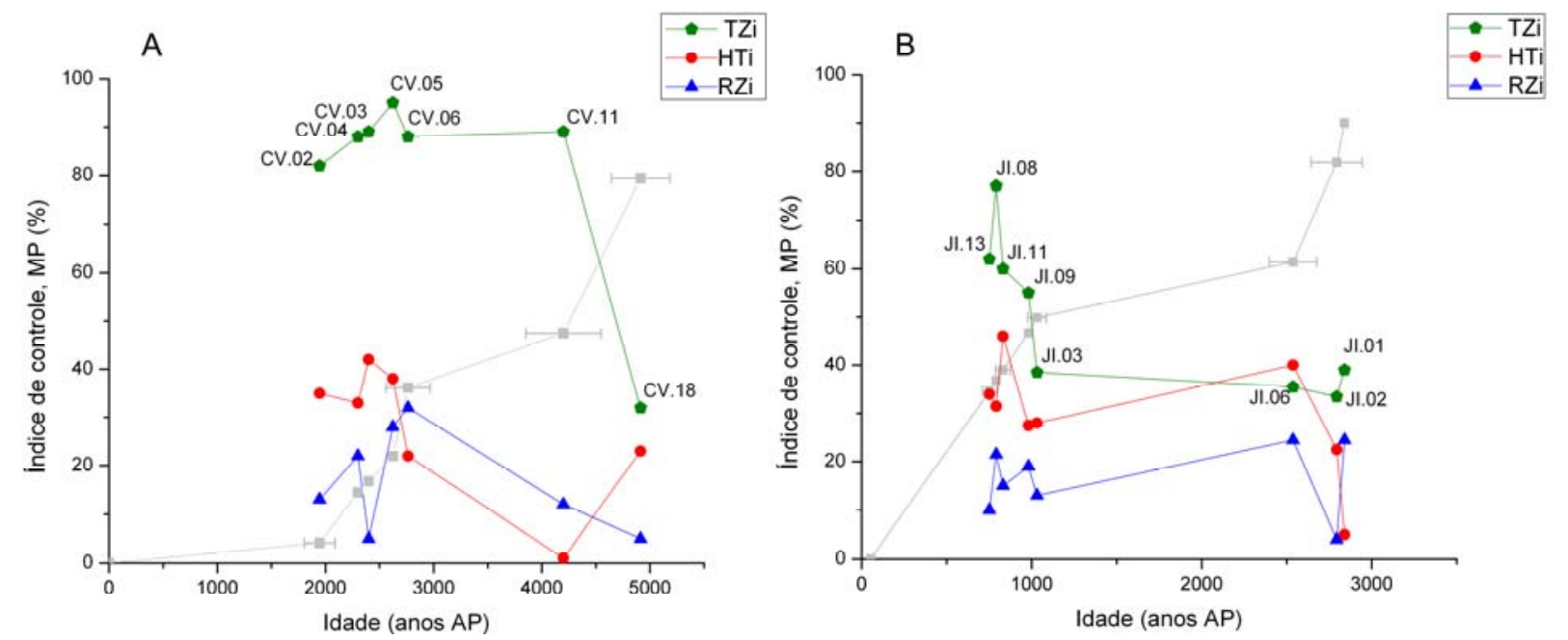

Figura 6.33 - Variação dos índices de controle (iHT, iTZ e iRZ) ao longo do tempo, as taxas de progradação estão representadas ao fundo em cinza claro. A) Campos Verdes. B) Ji.

Assim, o "boom" progradacional encontrado por volta de 2700 anos AP para as planícies de Campos Verdes e Ji corresponderia ao segundo evento de escala milenar (Bond event 2) que ocorreu por volta de 2800 anos AP, caracterizado por aumento de precipitação nas latitudes médias do hemisfério sul, incluindo a costa de Santa Catarina (Cruz et al. 2007).

Embora suposta como de abrangência global, o Bond event 2 possui diferentes tpos de manifestações climáticas, dependendo do hemisfétrio e da latitude. Na Irlanda, Plunkett \& Swindles (2008), com base no registro de variação de ${ }^{14} \mathrm{C}$, descrevem período seco e frio em 2800 anos AP, com mudanças abruptas para condições mais úmidas em 2700 anos AP. Nas regiões baixas da Holanda, Van Geel et al. (1996) interpretam mudança brusca na concentração de ${ }^{14} \mathrm{C}$ da atmosfera relacionada a alteração climática entre 2750 e 2450 anos $\mathrm{AP}$, com consequente aumento do nível freático. Essas mudanças encontradas no Atlântico Norte foram correlacionadas a enfraquecimento do regime das monções do Oceano Índico e da Ásia por Gupta et al. (2003). Estes autores sugerem relação entre o mecanismo responsável pelos eventos climáticos de escala milenar registrados no Atlântico Norte e o mecanismo gerador de mudanças abruptas no regime das monções do sudoeste da Ásia. O 
registro de mudanças climáticas simultâneas em latitudes diferentes confirmaria o caráter global para Bond events.

Através da comparação das variações isotópicas de $\delta^{18} \mathrm{O}$ obtidas em estalagmites da caverna Botuverá, em Santa Catarina (Cruz et al. 2006, Wang et al. 2006) e da caverna de Dongee (Wang et al. 2006), na China, observa-se que durante o segundo evento climático de escala milenar, há uma tendência para queda de $\delta^{18} \mathrm{O}$ (entre 3100 e 2500 anos AP, aproximadamente), com pico negativo por volta de 2528 anos, no registro da caverna de Botuverá, e para aumento (entre 3006 e 2705 anos AP, aproximadamente) com pico positivo de $\delta^{18} \mathrm{O}$ por volta de 2705 anos, no registro da caverna de Dongee. Tendências opostas também podem ser observadas na comparação entre a variação de ${ }^{14} \mathrm{C}$ atmosférico registrado no Chile (Van Geel et al. 2000), que indica condições mais umidas por volta de 2700 anos atrás, e as concentrações mínimas de ferro (\%Fe) e titânio (\%Ti) registradas em sedimentos da bacia do Cariaco (Haug et al. 2001) que indicam menor aporte terrígeno e, portanto, condições mais secas nessa área por volta de 2800 anos AP (apesar de situar-se no hemisfério sul, a bacia do Cariaco encontra-se a norte da Zona de Convergência Intertropical, ZCIT, portanto com tendência semelhantes as encontradas nos registros de variações das faixas de baixa latitude do Atlântico Norte). Desse modo, os eventos climáticos holocênicos de escala milenar (Bond events) poderiam ser considerados períodos de deslocamento da ZCIT e da banda de calor e umidade para sul. Seriam assim caracterizados por avanço de geleiras nas altas latitudes e por clima mais frio nas médias latitudes do hemisfério norte (por exemplo, Irlanda e Holanda), por clima mais seco nas baixas latitudes (por exemplo, Dongee e bacia do Cariaco) e por aumento de precipitação nas médias latitudes do hemisfério sul (por exemplo Sul do Chile e Sul/Sudeste do Brasil).

$\mathrm{O}$ aumento abrupto no conteúdo de ${ }^{14} \mathrm{C}$ atmosférico no Chile (Van Geel et al. 2000) por volta de 2700 anos AP é interpretado pelos autores como resultado de mudança climática relacionada a diminuição da irradiação solar através da amplificação de dois fatores: (1) aumento da intensidade da radiação cósmica, que teria estimulado a formação de nuvens e a precipitação; e (2) redução da intensidade ultra-violeta solar, o que teria acarretado declínio da produção de ozônio na estratosfera, com queda da absorção da luz solar e conseqüente esfriamento da superfície .

Uma série de dados regionais cosubstancia o registro de evento climático de escala milenar (Bond event 2, por volta de 2700 anos AP) em Santa Catarina ou Sul do Brasil e suas possíveis relações com o aumento das taxas de aporte fluvial e progradação costeira:

1) Esse período corresponde ao segundo dos três momentos de estabilização de dunas eólicas (4820-3970, 2760-2460 e 1570-710 anos AP) inferidos no setor costeiro de Torres a Mostardas (RS), por Martinho et al. (2008), com base na datação de paleossolos de extensão ampla, e interpretados por mesmos autores como períodos de maior umidade. 
2) O mesmo período encontra-se compreendido na fase de redução de salinidade (3455-2555 anos AP) detectada por Amaral (2008) por análise de diatomáceas em testemunho de sondagem no paleovale inciso afogado do Riachinho, município de Jaguaruna (SC). Segundo a autora, o registro de diminuição de salinidade (Fig.6.34) corresponderia a intervalo onde há queda abrupta nas curvas de razões isotópicas de oxigênio obtidas por Wang et al. (2006) e Cruz et al. (2006) a partir de espeleotemas da caverna Botuverá (também localizada em Santa Catarina, cerca de $150 \mathrm{~km}$ a NNW da área estudada), o que indicaria aumento da freqüência e intensidade de chuvas de verão e contribuição para aumento geral na quantidade de chuvas no período (Amaral 2008). De acordo com Cruz et al. (2005), a contribuição relativa das chuvas de inverno e chuvas de verão é refletida no registro da razão isotópica do oxigênio nos espeleotemas da região subtropical do Brasil. A variação do sinal isotópico ocorreria assim de acordo com a mudança da fonte de umidade das chuvas. Valores de $\delta{ }^{18} \mathrm{O}$ mais baixos que os das chuvas de inverno associam-se as às monções de verão da América do Sul, com fonte de umidade distante e passagem de ciclones extratropicais ao longo da costa atlântica. Cruz et al. (2007) relacionam a intensificação de chuvas de verão a aumento geral da chuva média, a partir da análise integrada de $\delta^{18} \mathrm{O}$ e razões $\mathrm{Sr} / \mathrm{Ca}$ e $\mathrm{Mg} / \mathrm{Ca}$. Desse modo, com razões isotópicas de oxigênio em queda haveria mais chuva em Santa Catarina.

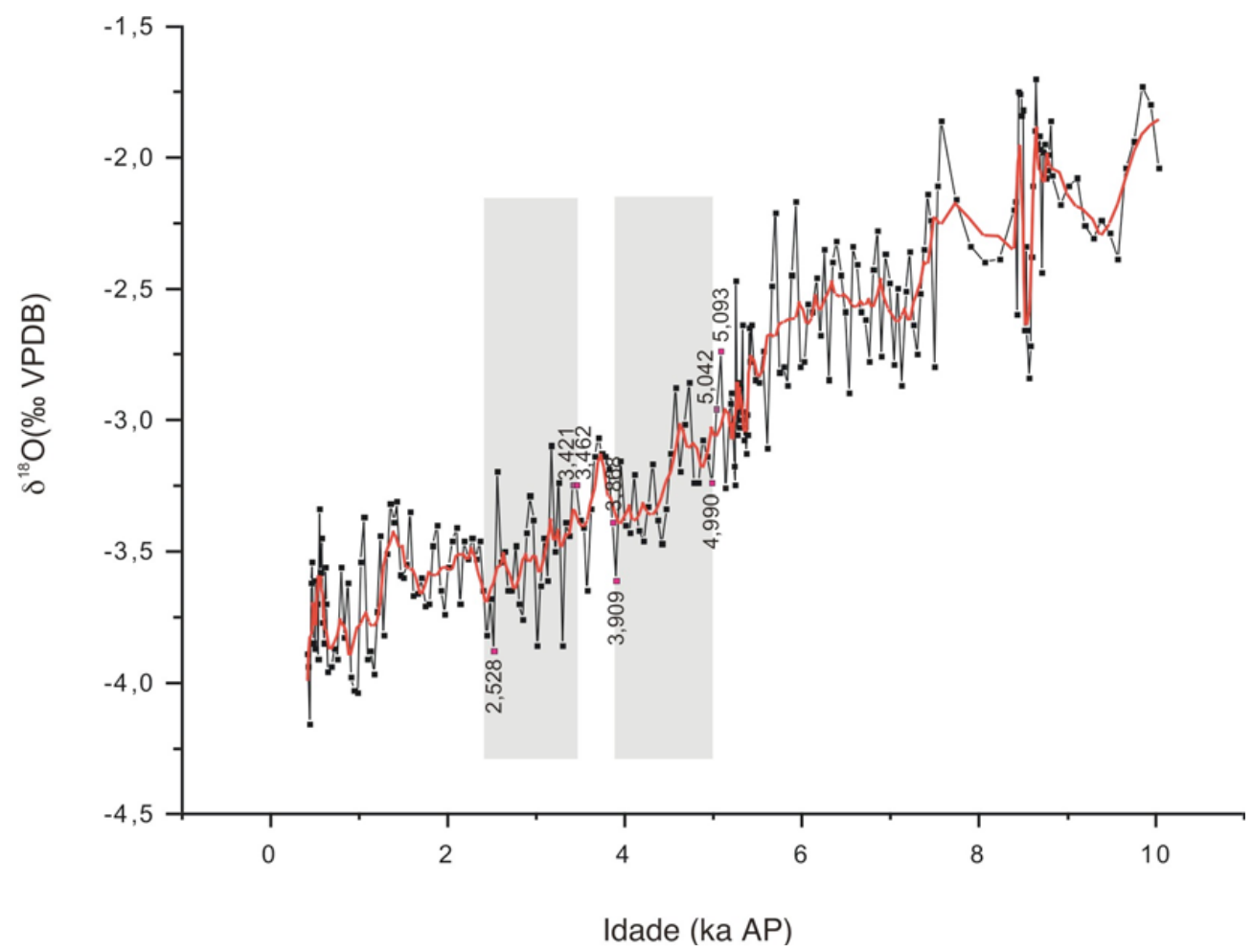

Figura 6.34 - Gráfico de variação isotópica ao longo do tempo, registrada em estalagmite da caverna Botuverá, em Santa Catarina (Cruz et al. 2006, Wang et al. 2006) e sua relação com os períodos, ressaltados em cinza por Amaral (2008), de diminuição de salinidade dentro da paleolaguna do vale do Riachinho, pertencente ao sistema lagunar Garopaba do Sul - Santa Marta - Santo Antônio. Extraído de Amaral (2008). 
3) No mesmo sistema lagunar estudado por Amaral (2008), situado a sul de Campos Verdes, dados isotópicos e idades ${ }^{14} \mathrm{C}$ obtidos por Fornari et al. (2008) em amostras de conchas de Anomalocardia brasiliana recolhidas a partir de vibrotestemunhos indicam valores mais negativos de $\delta^{18} \mathrm{O}\left(-0.50 \%\right.$ to $-1.80 \%$ o PDB) e diminuição de $\delta^{13} \mathrm{C}(1.22 \%$ o to $0.20 \%$ ) no período de 5150 a 2400 anos (Fig.6.35). Os autores comparam o padrão de variação das razões isotópicas de carbono e oxigênio com a variação obtida por Angulo et al. (1999) para o vermitideo Petaloconchus (Macrophragma) varians, gastrópode bentônico séssil coletado em costão rochoso na costa de Laguna e Imbituba. Nos mesmos intervalos de tempo, ocorre padrão inverso que reflete mudanças isotópicas da composição da água em que cada espécie habita: vermetídeos vivem em mar aberto, ou seja, em água isotopicamente mais pesada (águas marinhas), enquanto os bivalves estudados habitam águas de mistura (lagunares). O mar aberto é enriquecido em isótopos pesados enquanto águas continentais provenientes do rio Tubarão são enriquecidas em isótopos leves. Assim mudanças isotópicas indicam mudanças na fonte de contribuição de águas. Fornari et al. (2008) interpretam a queda de isótopos pesados nas conchas de Anomalocardia brasiliana como um indicador de diminuição da conexão do sistema lagunar com o mar aberto associada a progradação da barreira e progressivo fechamento das desembocaduras lagunares. Se o fechamento das lagunas está relacionado ao maior aporte sedimentar, então se supõe relação entre diminuição do sinal isotópico das lagunas com aumento das taxas de progradação. O período com menores valores de $\delta^{18} \mathrm{O}(2730-2690$ anos) coincide aproximadamente com o de "boom" progradacional em Campos Verdes (2816-2763 anos) e Ji (2763-2500 anos). É provável que, além da restrição das lagunas (fechamento acelerado relacionado ao maior aporte sedimentar), estes valores mais negativos de $\delta^{18} \mathrm{O}$ possam representar maior incursão de águas continentais por aumento da descarga dos distributários do rio Tubarão, ligada a incremento de pluviosidade. 


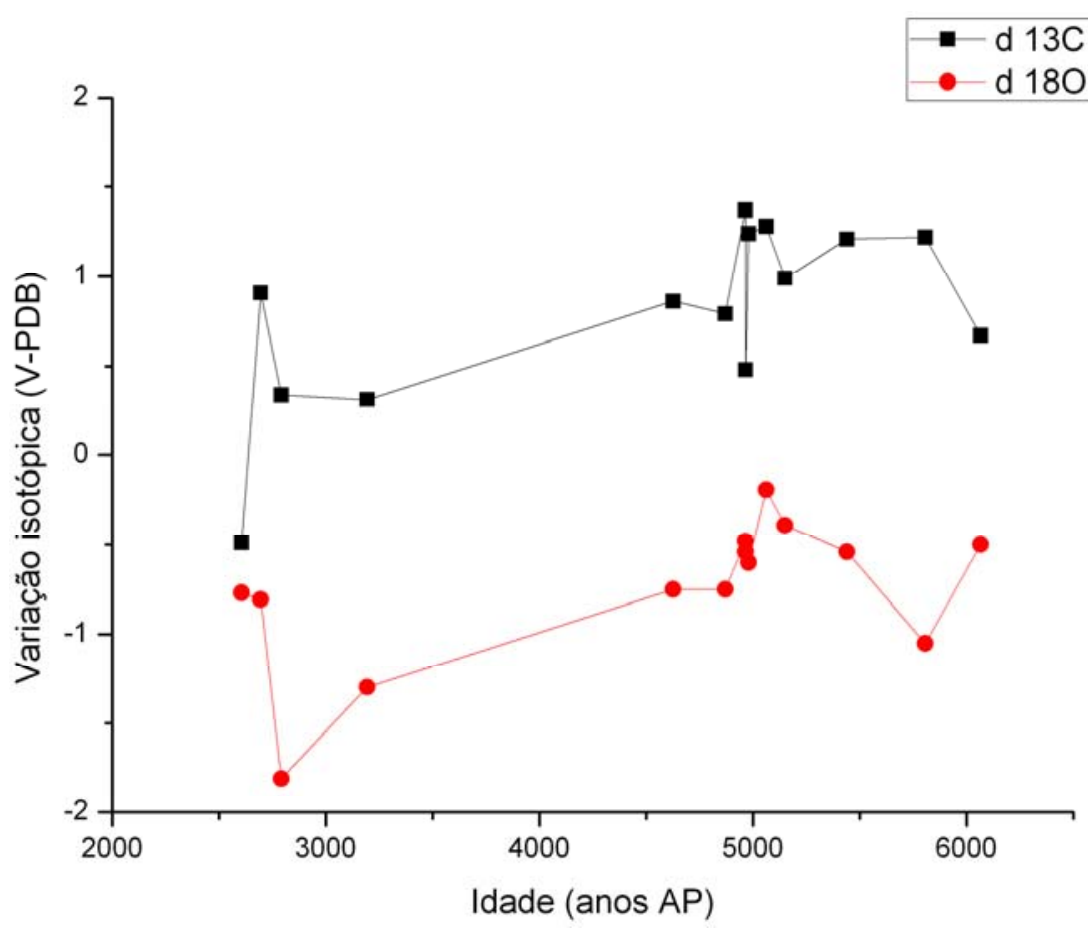

Figura 6.35 - Gráfico de variação isotópica ao longo do tempo de conchas de Anomalocardia brasiliana coletas no grande sistema de lagunas da região (Modificado de Fornari et al. 2008).

Portanto, o aumento de aporte sedimentar nas lagunas e em mar aberto via desembocaduras lagunares pode tanto ser resultado da aproximação do rio Tubarão, por efeito de progradação do delta, como de descarga mais efetiva associada a aumento de umidade/pluviosidade na região. Mais chuva durante o período de variação climática Bond 2 culminaria em maior progradação das duas planícies durante esse curto intervalo de tempo.

\subsubsection{Desenvolvimento dos campos de dunas}

Os depósitos eólicos ocorrem de dois modos distintos nas planícies estudadas: em lobos deposicionais parabólicos espessos (espessura de vários metros ou mesmo decamétrica: CV.08 e Jl.05) e em dunas parabólicas delgadas, de difícil individualização (espessura decimétrica: CV.10, CV.12, CV.13). Esta distinção pode ser percebida tanto em campo, nas áreas menos modificadas pelo homem, como, mais claramente, nas fotos aéreas mais antigas (1956). Os depósitos eólicos caracterizados por lobos deposicionais espessos apresentaram idades de $1346 \pm 73$ anos (JI.05), no Ji, e 2255 \pm 123 anos (CV.08), em Campos Verdes. Estas idades sugerem estabilização da geração eólica 3 durante o estágio 3 de evolução da planície do Ji (de $2537 \pm 140$ a $1031 \pm 35$ anos) e durante o estágio evolutivo 4 de Campos Verdes (de 2816 \pm 193 a $1946 \pm 141$ anos). Já as paleodunas eólicas representadas por formas parabólicas delgadas apresentaram idades de $711 \pm 64$ anos (CV.12), 368 \pm 30 anos (CV.10) e 174 \pm 14 anos (CV.13). A morfologia parabólica alongada e o escasso volume de areia destas dunas são típicos de elevada razão energia eólica / aporte sedimentar e, 
portanto, do domínio de deflação sobre deposição. Estas características, associadas a sua ocorrência a sotavento (SW) de lobos maiores (nas fotos aéreas de 1956) e às suas idades mais novas permitem sugerir origem por reativação tardia de depósitos eólicos preexistentes, após o estágio cronológico 4 de Campos Verdes. Em suma, as idades dos lobos deposicionais caracterizam momentos de estabilização de campos de dunas, enquanto as idades das dunas parabólicas delgadas podem representar momentos de reativação de depósitos eólicos preexistentes, via deflação e redeposição sob ventos intensificados.

O modelo apresentado por Tanaka (2007) para a formação das dunas de Campos Verdes considera que os vários grupos de paleodunas parabólicas alinhadas com cordões teriam sido formados, no decorrer da regressão, durante sucessivas fases de estabilização ou de suave erosão da linha de costa. Conseqüentemente, cada grupo de paleodunas representaria um pulso de sedimentação eólica durante hiatos progradacionais. Este modelo é compatível com a geometria e distribuição dos grupos de palodunas, intercalados com séries de cordões litorâneos. O modelo é compatível também com a evidência, em fotos aéreas de 1956 (Figura 5.1), de desenvolvimento de dunas parabólicas ativas na então margem erosiva de um meandro de distributário do rio Tubarão na porção noroeste da planície de Campos Verdes (Figura 6.1), o que reforça a hipótese de formação de depósitos eólicos induzida por estabilização ou erosão da costa (hiatos progradacionais).

Perante este modelo, a compreensão do significado dos resultados de datação LOE obtidos para os lobos deposicionais de Ji e Campos Verdes requer levar em consideração os seguintes aspectos: 1. trata-se aí de lobos alongados, que presumivelmente migraram centenas de metros a quilômetros da praia ou cordão de origem, portanto ao longo de séculos, antes de serem estabilizados; 2. as idades, obtidas nas frentes desses lobos correspondem ao momento de fim da migação e portanto de estabilização da duna, e não de sua geração inicial; 3. estas idades devem assim ser muitos anos mais novas tanto em relação ao substrato (série de cordões sob o depósito eólico transgressivo) como em relação à iniciação da própria duna junto à sua área fonte. Essa situação é bem exemplificada pelo depósito eólico datado em $1346 \pm 73$ anos (JI.05) sobre substrato de $2537 \pm 140$ na planície do $\mathrm{Ji}$.

Já as idades obtidas para os depósitos delgados caracterizariam fases de reativação dos campos de dunas e lobos deposicionais preexistentes, visto serem justamente estas as feições mais sobressalentes e mais novas (portanto, com menor tempo para o desenvolvimento de vegetação e pedogênese, em comparação aos cordões litorâneos) da planície, e, deste modo, com maior probabilidade de serem reativadas com a formação de blowouts e formas parabólicas famintas.

Isla et al. (2001) identificam três ciclos de geração de dunas costeiras para o sul e leste da província de Buenos Aires, Argentina, a partir de datações radiocarbônicas de 
amostras de barreiras de dunas costeiras. O terceiro destes ciclos, entre 1600 e 500 anos AP, é atribuído pelo autor a reativação de dunas. De acordo com Isla et al. (2001), os ciclos são sincrônicos com outros do hemisfério sul. A reativação/formação de dunas de Campos Verdes pode ser atribuída a aumento da velocidade e circulação eólica ligados à intensificação de ventos de NE. Na Região Sul do Brasil, a incursão de frentes frias é freqüente; antes de cada incursão, os ventos norte atuam e durante a frente fria, o vento muda de direção com ocorrência de chuva e erosão.

O aumento na circulação dos ventos durante a PIG pode ter sido fator favorável ou mesmo desencadeador da reativação dos depósitos eólicos, com produção de formas parabólicas delgadas como as das paleodunas mais novas da planície de Campos Verdes. Desse modo, estas paleodunas seriam resultado de reativação, ao longo dos últimos 712 anos, de paleodunas preexistentes, devido a intensificação dos ventos nesse período. Como hipótese alternativa, o ínicio do desenvolvimento/formação das paleodunas mais novas de Campos Verdes poderia ser atribuído ao evento climático da PIG de modo mais completo, ou seja, ao invés de reativadas a partir de paleodunas prévias, as dunas teriam sido inteiramente originadas durante esse evento. Para isso, no entanto, seria necessário supor a existência de depósitos mais expostos à deflação no meio da planície, por exemplo cordões mais elevados e/ou menos vegetados. E, pelo princípio da parcimônia, estes depósitos mais elevados e com menos cobertura vegetal seriam mais provavelmente as próprias dunas eólicas preexistentes.

$\mathrm{Na}$ Ilha Comprida (SP), cordões de dunas frontais altas (até $15 \mathrm{~m}$ ) com rupturas de deflação (blowouts) voltadas para NW também apresentaram idades LOE/SAR (entre $575 \pm 47$ e $172 \pm 18$ anos AP) compatíveis com o intervalo de tempo atribuído na literatura à PIG (Sawakuchi et al. 2008). Essas idades são mais antigas que os cordões de dunas frontais mais externos da llha Comprida, ao contrário do encontrado na planície de Campos Verdes. Assim, pelo tipo de duna e pela distribuição de idades, as dunas altas da llha Comprida foram correlacionadas por aqueles autores a aumento não só da atuação dos ventos e ondas de sul, como também do próprio suprimento eólico, durante a PIG.

No caso da PIG ter promovido a intensificação dos ventos para a Região Sudeste do Brasil (Ilha Comprida), como proposto por Sawakuchi et al. (2008), então é possível estender o aumento de circulação eólica ao Sul do Brasil, afetando a planície de Campos Verdes. Ou mesmo, a extensão para norte do aumento dos ventos de norte inferido por Isla et al. (2001) na província de Buenos Aires. Para melhor avaliar estas hipóteses, são necessárias mais idades LOE de blowouts nas regiões sul e sudeste da América do Sul. 


\subsection{Simulação}

O desenvolvimento de campos de dunas eólicos foi simulado de modo amplo (considerando vários estoques, da planície emersa à plataforma continental) e de modo restrito (com estoques limitados ao sistema praia-duna). No último caso, foram testados cenários mais úmidos, ou com maior pluviosidade, correspondentes aos dados meteorológicos regionais obtidos para o trimestre de janeiro, fevereiro e março (quando ocorre maior número de dias chuvosos, com preciptação média mensal de $438 \mathrm{~mm}$, mínimo de $200 \mathrm{~mm}$ e máximo de $817 \mathrm{~mm}$ ), mais secos ou com menor pluviosidade (correspondente aos dados obtidos para o trimestre de junho, julho e agosto, quando ocorre menor número de dias chuvosos, com precipitação média mensal de $339 \mathrm{~mm}$, mínimo de $147 \mathrm{~mm}$ e máximo de $818 \mathrm{~mm}$ ) e de umidade/precipitação intermediária. O objetivo desta comparação de cenários climáticos foi avaliar a possibilidade de formação e crescimento de dunas sob condições úmidas e de progradação da praia sob condições secas.

\subsubsection{Estimativa de volumes e fluxos}

Para a planície do Ji, o campo de dunas foi considerado uma pirâmide com base retangular na sua porção distal, junto ao morro do Mar Grosso (ponta do Iró), e vértice na ponta do $\mathrm{Ji}$, com a altura $\mathrm{h}$ correspondendo à extensão longitudinal do campo de dunas (Fig.6.36). O volume foi calculado segundo a fórmula do volume da pirâmide, conforme a equação 6.3:

$$
V_{\text {pirâmide }}=\frac{1}{3} \text { Área }_{\text {base }} . \text { Altura }=\frac{1}{3} 6900 \times 6100=1,40 \times 10^{7}\left[\mathrm{~m}^{3}\right]
$$

Já os demais compartimentos foram considerados prismas. Para o prisma praial, considerou-se base triangular adjacente ao morro do Mar Grosso (ponta do Iro) e altura (h) correspondente à extensão da praia ou setor costeiro (Fig.6.36), conforme a fórmula do volume do prisma (Eq.6.4):

$$
V_{\text {prisma }}=\text { Área }_{\text {base }} . \text { Altura }=1200 \times 5000=6,00 \times 10^{6}\left[\mathrm{~m}^{3}\right]
$$




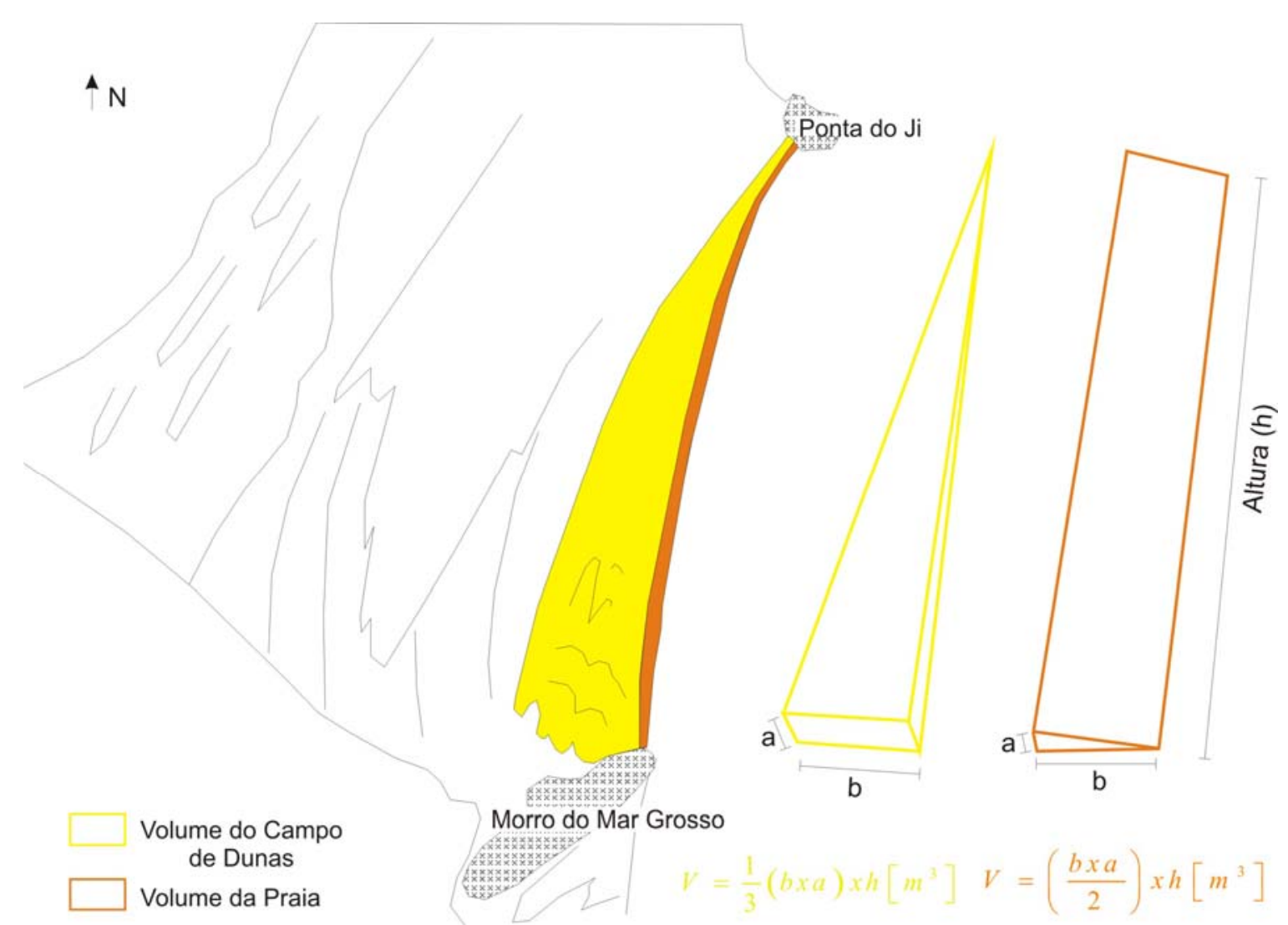

Figura 6.36 - llustração esquemática da praia e do campo de dunas, comparados a formas geométricas para cálculo aproximado dos volumes (estoques).

O volume calculado para o campo de dunas do $\mathrm{Ji}, 6,00 \times 10^{6} \mathrm{~m}^{3}$, é compatível em ordem de grandeza com o encontrado por Sawakuchi (2006) no campo de dunas de Itapirubá ou Vila Nova - Roça Grande $\left(3,29 \times 10^{7} \mathrm{~m}^{3}\right)$, situado poucos quilômetros a norte (município de Imbituba).

Para o continente e o mar, estimaram-se volumes sedimentares da ordem de $10^{8}\left[\mathrm{~m}^{3}\right]$, com base nas dimensões de prismas cuja extensão transversal à costa, ao interior ou costa afora, respectivamente, foi estabelecida em aproximadamente $5000 \mathrm{~m}$. Devido à imprecisão da estimativa, foram consideradas somente as ordens de grandeza.

Os fluxos de sedimentos entre continente, campo de dunas, praia e mar foram inicialmente estimados a partir das taxas de progradação, ou seja, com base na quantidade de sedimentos depositados no setor costeiro [ $\mathrm{m}^{2} / \mathrm{ano}$ ], ao longo do tempo em que se desejou rodar a simulação. Para isso, foi necessário estimar a taxa de progradação em volume por tempo [ $\mathrm{m}^{3} / \mathrm{ano}$ ], sendo testados valores da ordem de grandeza de $10^{4}\left[\mathrm{~m}^{3} / \mathrm{ano}\right.$. Os valores de fluxo foram comparados com as taxas de transporte por deriva litorânea de $4,00 \times 10^{3}$ $\mathrm{m}^{3} / a n$ a $6,20 \times 10^{4} \mathrm{~m}^{3} / a n o$, modeladas por Cipriani \& Stone (2001) para a ilha barreira do sudoeste do Alabama e Mississippi, no Golfo do México (EUA), e com valores da ordem de $2,70 \times 10^{4} \mathrm{~m}^{3} / \mathrm{dia}$ a $3,30 \times 10^{4} \mathrm{~m}^{3} / \mathrm{dia}$, estimados por Mendes (2009) para o setor centro-sul da praia de Peruíbe (entre os municípios de Peruíbe e Itanhaém, SP). Trata-se, neste segundo 
exemplo, de setor de estreitamento da praia devido à influência de uma construção a beira mar que barraria a chegada de fluxos sedimentares; portanto, tal valor possivelmente corresponderia a um fluxo ou taxa de troca de sedimentos.

Os fluxos poderiam ser considerados como parâmetros ou valores de entrada (inputs), ou seja, valores digitados no início da simulação, porém foram abordados aqui como valores testados através da repetição de simulações.

Os números de iterações foram escolhidos com base na datação do substrato da duna (idade máxima da duna, aproximadamente 750 anos); desse modo, parte-se da premissa de que o campo de dunas simulado tenha sido desenvolvido ao longo dos últimos 750 anos e simulam-se os efeitos de diferentes situações relacionadas ao regime de chuvas, que poderiam ter ocorrido durante esse período.

\subsubsection{Cenário geral: trocas de sedimentos}

O primeiro cenário testado foi o geral, construído a partir de uma cadeia de Markov organizada com base em probabilidades de existirem trocas entre cinco compartimentos da planície do Ji e adjacências: continente, campo de dunas 1, campo de dunas 2, praia e mar. A estrutura do modelo é apresentada no anexo 4. O cenário geral foi simulado para um intervalo de 750 anos, de acordo com a matriz da Tabela 6.7 e os parâmetros da Tabela 6.8.

Tabela 6.7 - Matriz de probabilidades para trocas de sedimentos entre os compartimentos (continente, campo de dunas 1, campo de dunas 2, praia e mar) do cenário geral.

\begin{tabular}{|c|c|c|c|c|c|}
\hline & Cont. & Cd1 & Cd2 & Praia & Mar \\
\hline Continente & 0,2 & 0 & 0 & 0,8 & 0 \\
\hline Cd1 & 0 & 0,9 & 0 & 0,1 & 0 \\
\hline Cd2 & 0 & 0 & 1 & 0 & 0 \\
\hline Praia & 0 & 0,8 & 0 & 0 & 0,2 \\
\hline Mar & 0 & 0 & 0 & 0,9 & 0,1 \\
\hline
\end{tabular}

Tabela 6.8 - Parâmetros iniciais (input) para simulação do cenário geral.

\begin{tabular}{|c|c|c|c|c|c|}
\hline Estoque inicial $\left(\mathrm{m}^{3}\right)$ & 100000000 & 0 & 0 & 75000 & 100000000 \\
\hline Estoque mínimo $\left(\mathrm{m}^{3}\right)$ & 10000000000 & 0 & 0 & 10000000000 & 10000000000 \\
\hline Estoque máximo $\left(\mathrm{m}^{3}\right)$ & 10000000000 & 10000000000 & 0 & 10000000000 & 10000000000 \\
\hline Fluxo de saída $\left(\mathrm{m}^{3} / \mathrm{ano}\right)$ & 19250 & 2500 & 0 & 25000 & 19250 \\
\hline
\end{tabular}

Os volumes simulados para um intervalo de tempo de 750 anos, $6,11 \times 10^{8} \mathrm{~m}^{3}$, para a praia, e $1,46 \times 10^{7} \mathrm{~m}^{3}$, para o campo de dunas, aproximam-se dos volumes reais calculados, de $6,00 \times 10^{8} \mathrm{~m}^{3}$ e $1,40 \times 10^{7} \mathrm{~m}^{3}$, respectivamente (Fig.6.37 e Tab.6.9). 


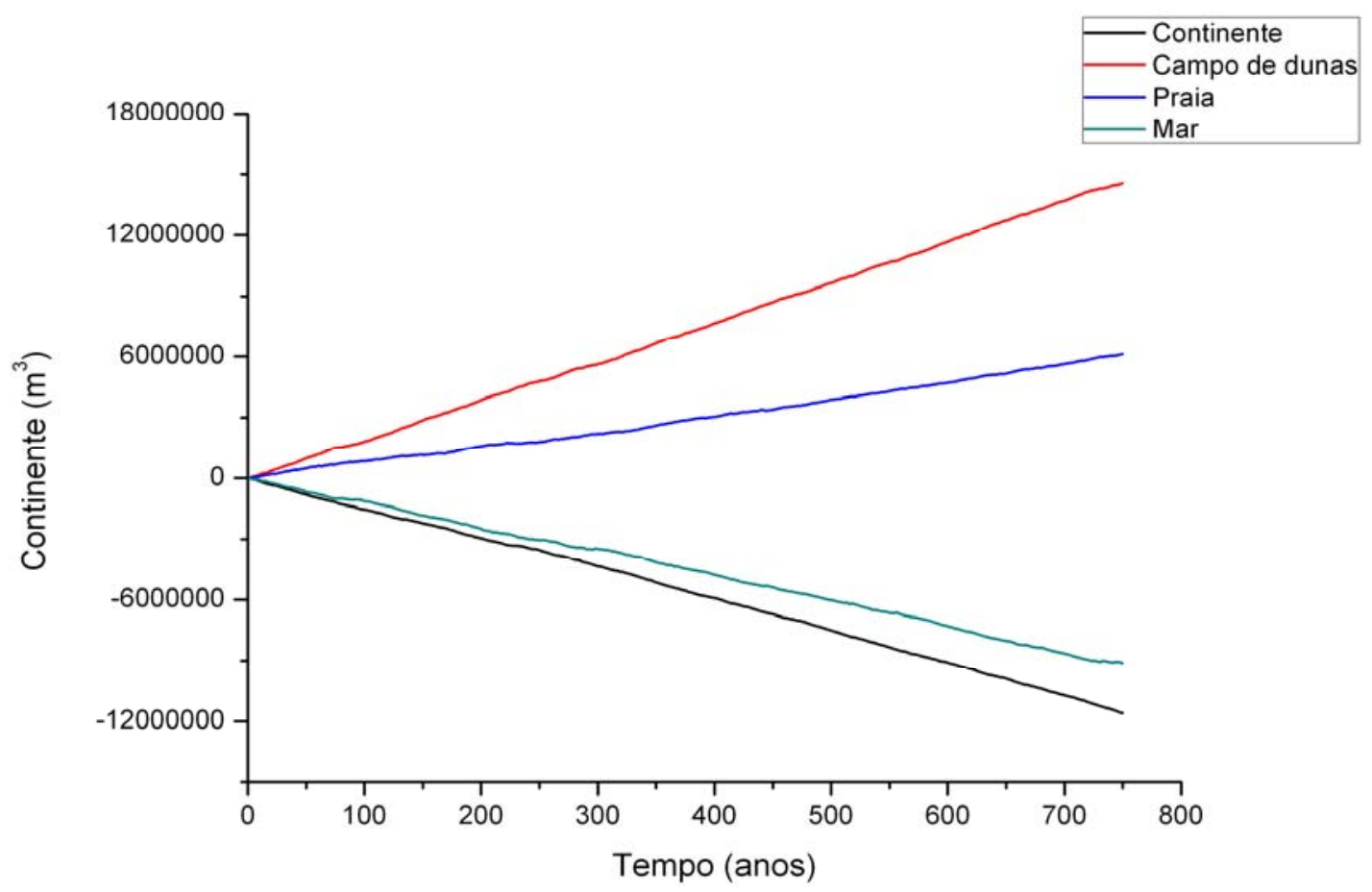

Figura 6.37 -Gráfico obtido como resultado da simulação do cenário geral: volume acumulado $\left(\mathrm{m}^{3}\right)$ ao longo do tempo (anos), para um período total de 750 anos.

Tabela 6.9 - Comparação entre os valores reais e os valores obtidos em simulação (modelo), para o cenário geral.

\begin{tabular}{|c|c|c|c|}
\hline REAL & $\mathrm{t}($ anos $)$ & $\mathrm{V}_{\text {praia }}\left(\mathrm{m}^{3}\right)$ & $\mathrm{V}_{\text {cd }}\left(\mathrm{m}^{3}\right)$ \\
\hline Condições iniciais & 0 & 75000 & 0 \\
\hline Condições finais & 750 & 6000000 & 14030000 \\
\hline MODELO & $\mathrm{t}($ anos $)$ & $\mathrm{V}_{\text {praia }}\left(\mathrm{m}^{3}\right)$ & $\mathrm{V}_{\text {cd }}\left(\mathrm{m}^{3}\right)$ \\
\hline Condições finais & 750 & 6112500 & 14577500 \\
\hline
\end{tabular}

A obtenção de valores próximos aos reais foi condicionada às probabilidades de trocas entre compartimentos e, principalmente, aos valores de fluxo simulados, que são compatíveis aos encontrados na literatura. Com base no modelo criado para o cenário geral, foi construído o modelo do sistema praia-duna apresentado a seguir.

\subsubsection{Sistema praia-duna: variação climática}

Foram construídos três cenários com condicionantes climáticos (chuva, vento, maré). A estrutura principal do modelo representa trocas de sedimentos entre unidades de sedimentação ou compartimentos (praia e campo de dunas), dentro do sistema praia-duna. $O$ cenário 1 do sistema praia-duna caracteriza uma calibração de acordo com os dados reais para um período de clima mais úmido ou de maior precipitação, sendo que os mesmos valores de fluxo utilizados na calibração foram também simulados para período mais seco ou de menor precipitação e período de preciptação intermediária. O cenário 2 foi calibrado para clima seco, sendo que os mesmos valores de fluxo foram utilizados para período 
intermediário e úmido. O cenário 3 representa a calibração para um período intermediário (ameno) e, como nos demais cenários, os valores calibrados de fluxo foram simulados para período úmido e seco. Foram simulados 365 dias e o passo (time step) escolhido para a integração foi de 0,125 dias, sendo que os estoques foram posteriormente acumulados para 750 anos.

A estrutura principal do modelo (Fig.6.38) foi construída em dois níveis, representados por duas variáveis principais (praia e campo de dunas), caracterizadas como estoques e ilustradas por caixas. As trocas foram caracterizadas por fluxos/vazões, ilustradas por setas grossas. As demais variáveis são chamadas de auxiliares e condicionam o sistema. Sua ligação com a estrutura principal é representada por setas finas, de acordo com a proposta de Sterman (2000).

As variáveis em cinza são chamadas de variáveis fantasmas, pois são usadas em outras abas (views) do programa. Assim, seus valores são atribuídos nestas outras abas e carregados na aba principal no mesmo passo da simulação. As equações que caracterizam cada variável encontram-se descritas no anexo 5.

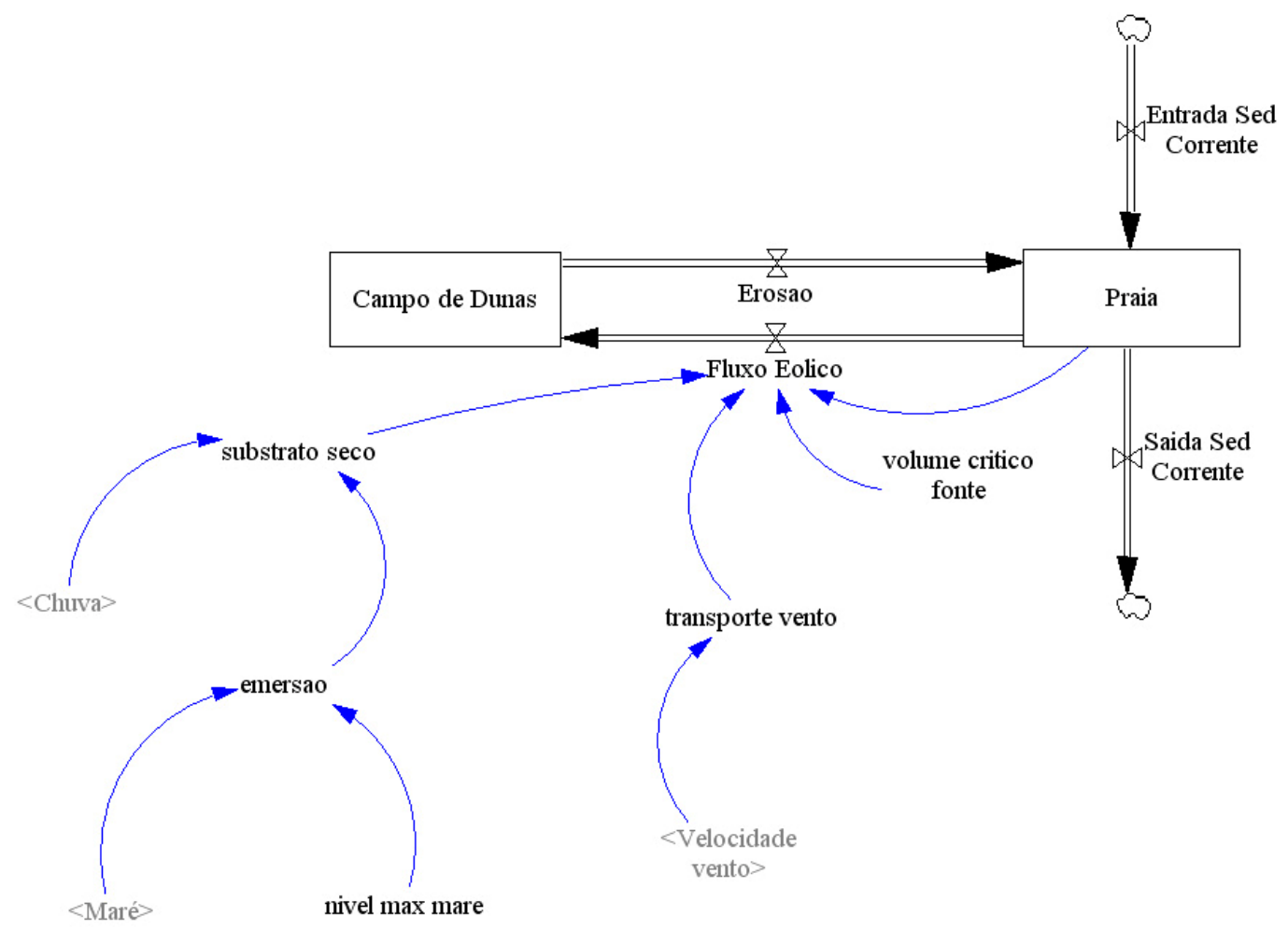

Figura 6.38 - Estrutura do modelo para simulação dos cenários condicionados por variáveis climáticas no sistema praia-duna.

\subsubsection{Geração de chuva, vento e maré}

A geração de números aleatórios foi realizada a partir de uma semente escolhida para possibilitar a reprodução do experimento outras vezes (por exemplo, semente=2010), os 
parâmetros mínimo, máximo e médio são colocados na equação da variável distribuição de chuva/vento/maré e o desvio padrão é digitado na variável desvio padrão no efeito aleatório da chuva/vento/maré. Os valores atribuídos às variáveis climáticas (Fig.6.39) foram utilizados na aba principal.

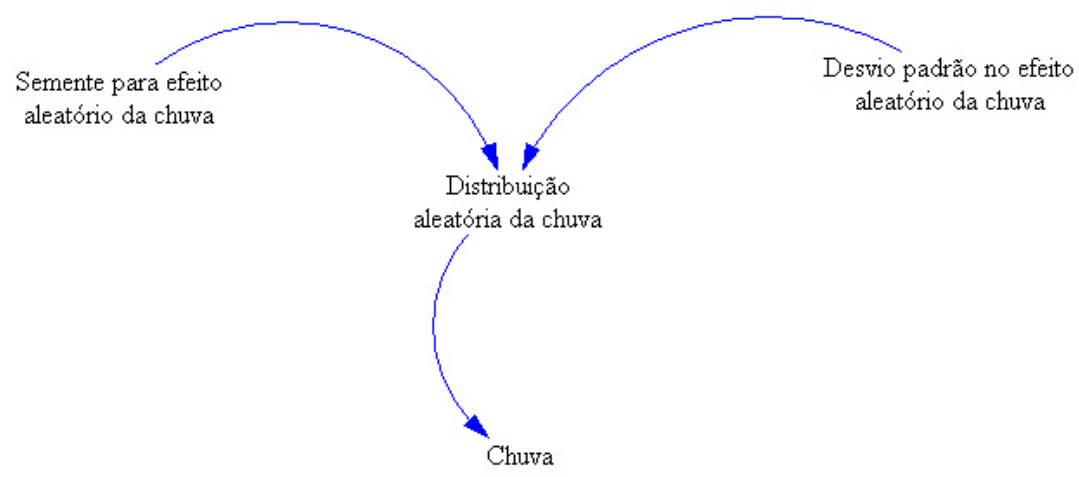

Figura 6.39 - Detalhe da estrutura do modelo gerador de números aleatórios para a distribuição de chuvas.

Para simular a velocidade do vento, utilizou-se uma distribuição normal, truncada no máximo de $16 \mathrm{~m} / \mathrm{s}$ e no mínimo de $0 \mathrm{~m} / \mathrm{s}$. A distribuição real dos dados foi baseada em valores próximos aos da distribuição apresentada por Sawakuchi (2006), por sua vez modificada de Tomazelli (1990) (Fig.6.40).

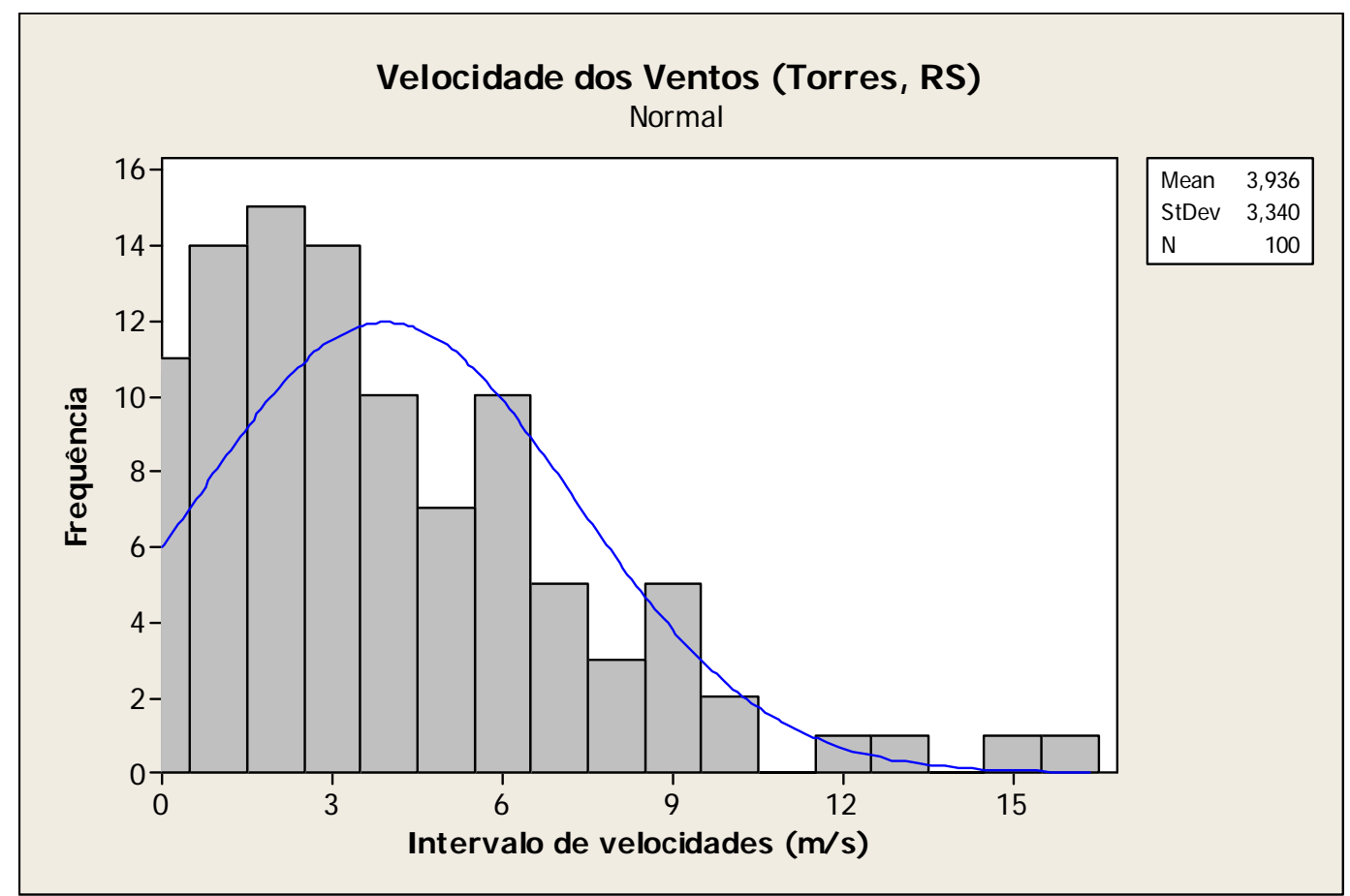

Figura 6.40 - Distribuição da velocidade dos ventos modificada de Tomazelli (1990) e Sawakuchi (2006).

No modelo, uma das condições para haver fluxo eólico é a ocorrência de velocidades do vento superiores à velocidade limiar de transporte pelo fluido $(a r)$. Esta velocidade $\left(V_{t}\right)$ foi 
calculada a partir da velocidade de arrasto limiar $\left(\mathrm{V}^{*}\right)$ através da substituição da equação 6.5 na equação 6.6 de acordo com Bagnold (1941).

$$
\begin{gathered}
V_{*}=A \sqrt{\frac{\sigma-\rho}{\rho} g d} \\
V_{t}=5,75 . V_{*}(\log z-\log k)
\end{gathered}
$$

A velocidade de arrasto limiar foi determinada de maneira empírica por Bagnold (1941) e pode ser calculada segundo a equação 6.5, onde $\sigma$ é a viscosidade do fluído, no caso a do ar $\left(\sigma=1,225 \mathrm{~kg} / \mathrm{m}^{3}\right)$, $\rho$ é a densidade do grão, no caso a do quartzo $\left(\rho=2650 \mathrm{~kg} / \mathrm{m}^{3}\right)$, $\mathrm{g}$ é a aceleração da gravidade $\left(\mathrm{g}=9,8 \mathrm{~m} / \mathrm{s}^{2}\right)$, e d é o diâmetro do grão, no caso areia fina $(\mathrm{d}=0,2 \mathrm{~mm}$ ou $0,0002 \mathrm{~m})$. Para o transporte aéreo de grãos de diâmetro maior ou igual a aproximadamente $0,25 \mathrm{~mm}$ atribui-se o valor 0,1 (adimensional) para a constante $A$; este valor está relacionado ao número crítico de Reynolds igual a 3,5, que corresponde ao limite entre as superfícies denominadas tecnicamente de rugosa e lisa. Quando o número de Reynolds é inferior a 3,5, ou o diâmetro do grão ou a velocidade de arrasto são menores, a superfície se torna lisa e o estado do fluxo se modifica para laminar. Desse modo, os valores do coeficiente A começam a aumentar a partir de granulações menores que $0,2 \mathrm{~mm}$ e a lei da raiz quadrada (equação 6.5) não mais se aplica para o cálculo da velocidade de arrasto limiar. Assim, adotou-se no cálculo de velocidade o diâmetro mais fino, dentro da classe areia fina, em que se pode ter leito rugoso e fluxo turbulento. Este valor de tamanho de grão situa-se no mesmo intervalo granulométrico que o valor médio encontrado nos sedimentos do sistema praia-duna da região.

A velocidade de arrasto limiar $\left(V^{*}\right)$ determina a capacidade de transporte através de um fluido, no caso o vento, de acordo com a relação apresentada na equação 6.6. A velocidade de transporte pelo vento aumenta de forma linear com o logaritmo da altura (z), onde $V_{t}$ é a velocidade de transporte pelo fluido, 5,75 é o fator de proporção entre a taxa de aumento da velocidade do vento e o logaritmo da altura da coluna de vento, $\mathrm{V}$ * é a velocidade de arrasto e k é uma constante associada à rugosidade da superfície. A rugosidade, por sua vez, está relacionada aos tamanhos das irregularidades que a constituem. Ao supor que a superfície é formada por grãos de areia, é possível estabelecer a relação de k igual a 1/30 do diâmetro dos grãos, segundo Bagnold (1941).

Para a velocidade limiar de arrasto, foi obtido o valor de $0,21 \mathrm{~m} / \mathrm{s}$ e a velocidade de transporte foi calculada em 3,73m/s. Este valor é compatível em ordem de grandeza com os 5m/s estimados por Hunter \& Richmond (1988) para haver transporte eólico de sedimentos com tamanho entre areia fina a areia média $(0,25 \mathrm{~mm})$.

Outra condição para haver transporte eólico é o substrato apresentar-se seco, ou seja, não ocorrer chuva. Para a geração de chuvas, foram utilizados três tipos de 
distribuições trimestrais: a distribuição do período úmido (meses de janeiro, fevereiro e março, JFM- Fig.6.41A) que apresentou média igual a $438 \mathrm{~mm}$ e foi truncada no máximo de $807 \mathrm{~mm}$ e no mínimo de $200 \mathrm{~mm}$; a distribuição do período intermediário ou ameno (meses de agosto, setembro e outubro, ASO- Fig.6.41B), com média igual a $404 \mathrm{~mm}$, máximo de $686 \mathrm{~mm}$ e mínimo de 114mm; e a distribuição seca (meses de junho, julho e agosto, JJA- Fig.6.41C), caracterizada por média igual a 339mm e truncada no valor máximo de 818 e no mínimo de $147 \mathrm{~mm}$. A ocorrência de chuva foi associada ao valor limite adotado igual a $400 \mathrm{~mm}$, ou seja, se a precipitação média gerada na distribuição aleatória for superior a $400 \mathrm{~mm}$, ocorre chuva, se for inferior, não ocorre chuva.
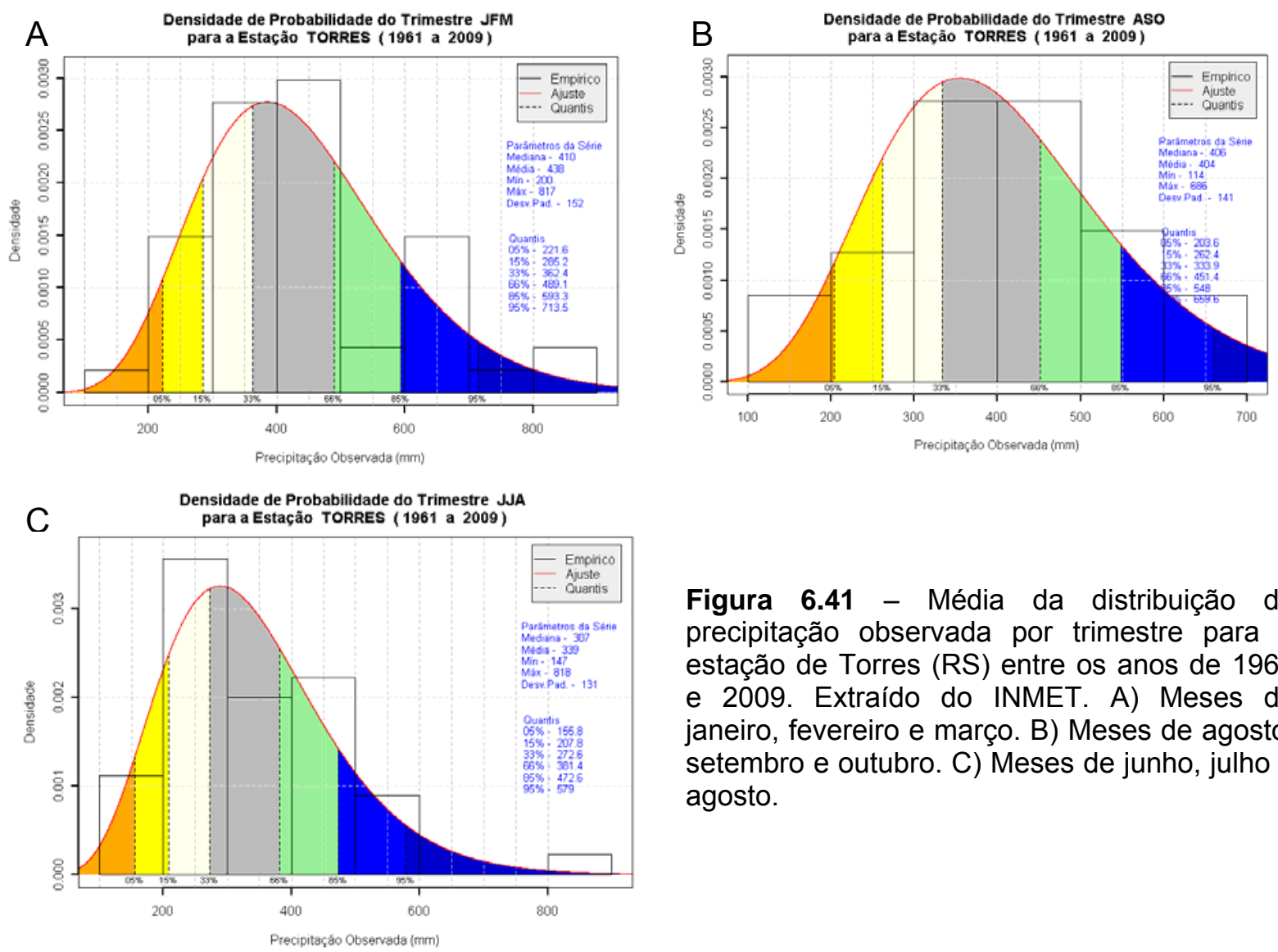

Figura 6.41 - Média da distribuição da precipitação observada por trimestre para a estação de Torres (RS) entre os anos de 1961 e 2009. Extraído do INMET. A) Meses de janeiro, fevereiro e março. B) Meses de agosto, setembro e outubro. C) Meses de junho, julho e agosto.

A condição de substrato seco depende não somente da não ocorrência de chuva, mas da emersão do substrato e, portanto, da posição e amplitude da maré. Em relação ao condicionamento por esta variável, o substrato foi considerado emerso na simulação para amplitude de maré inferior a 0,8m. A curva de distribuição de freqüências de amplitudes de maré foi calculada com base nos dados do porto de Imbituba e encontra-se na Figura 6.42. 


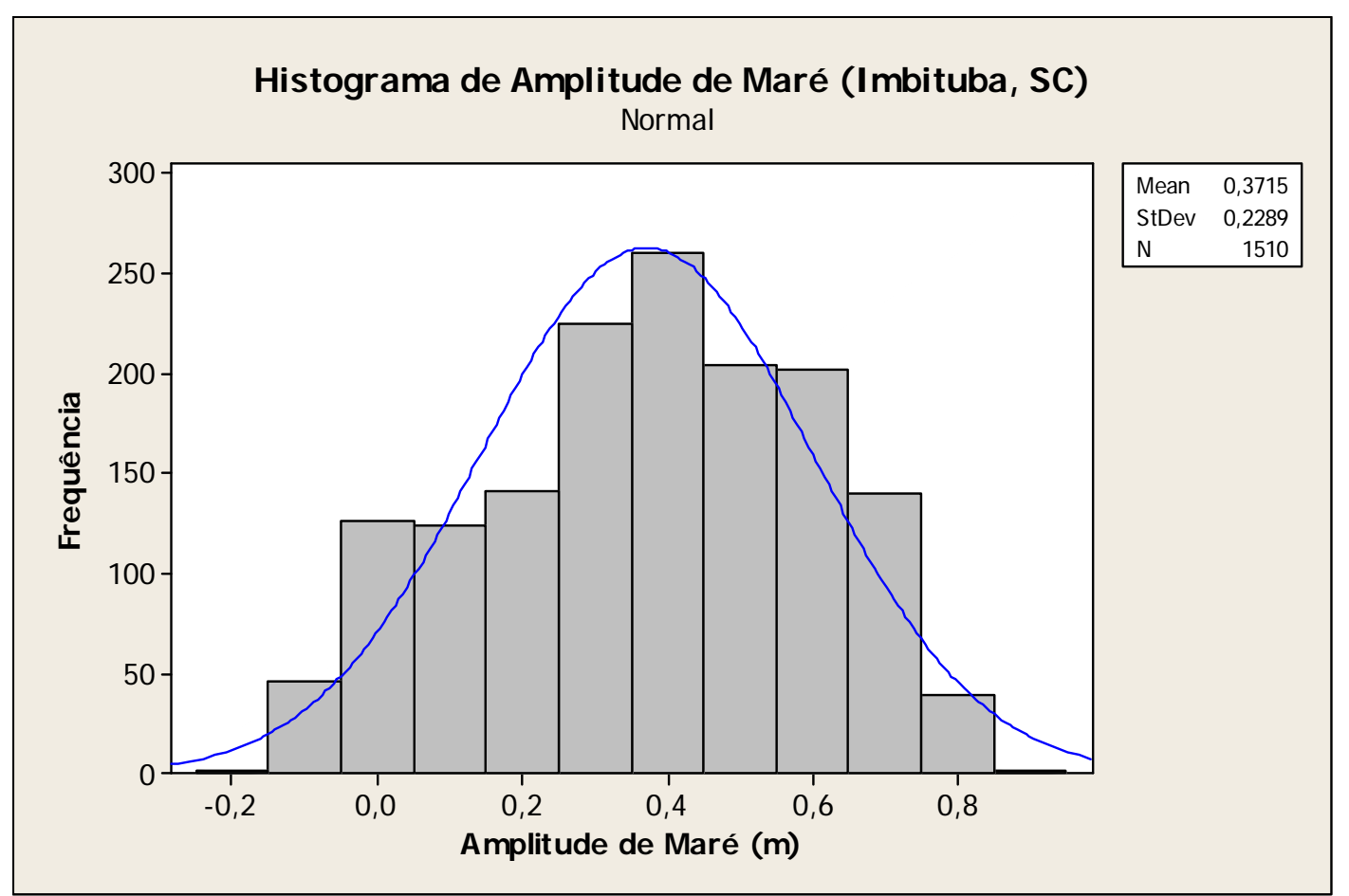

Figura 6.42 - Distribuição das amplitudes de maré ao longo do ano de 2008 no porto de Imbituba.

\subsubsection{Cenários}

Assim como no modelo geral, o volume inicial real da praia da planície do Ji foi calculado em $75.000\left(7,50 \times 10^{4} \mathrm{~m}^{3}\right)$ e os volumes finais reais da praia e do campo de dunas da planície do $\mathrm{Ji}$ foram calculados em $6.000 .000\left(6,00 \times 10^{6} \mathrm{~m}^{3}\right)$ e $14.030 .000\left(1,40 \times 10^{7} \mathrm{~m}^{3}\right)$ respectivamente.

CENÁRIO 1) O cenário 1 compreende a calibração dos dados para o período úmido, com regime de chuvas semelhante ao do trimestre janeiro-fevereiro-março. Para a simulação, foram considerados parâmetros apresentados nas Tabelas 6.10 e 6.11 .

Tabela 6.10 - Parâmetros climáticos utilizados para simular cenário de clima úmido.

\begin{tabular}{|c|c|c|c|c|c|c|}
\hline Distribuições Aleatórias & Minímo & Máximo & Médio & D.padrão & Semente & Limite \\
\hline Chuva $(\mathrm{mm})$ & 200 & 817 & 438 & 152 & 2010 & 400 \\
\hline Maré $(\mathrm{m})$ & $-0,2$ & 0,9 & 0,4 & 0,2 & 2010 & 0,8 \\
\hline Velocidade do vento $(\mathrm{m} / \mathrm{s})$ & 0,10 & 16,00 & 3,94 & 3,34 & 2010 & 2,76 \\
\hline
\end{tabular}

Tabela 6.11 - Parâmetros inicias de estoque e fluxo para simular o cenário 1 do sistema praia-duna.

\begin{tabular}{|c|c|}
\hline Modelo (período úmido) & Condições Iniciais \\
\hline Estoque Praia $\left(\mathrm{m}^{3}\right)$ & 75000 \\
\hline Estoque Campo de Dunas $\left(\mathrm{m}^{3}\right)$ & 1 \\
\hline Erosão $\left(\mathrm{m}^{3} / \mathrm{dia}\right)$ & 25 \\
\hline Fluxo Eólico $\left(\mathrm{m}^{3} / \mathrm{dia}\right)$ & 330 \\
\hline Entrada de Sedimentos Corrente $\left(\mathrm{m}^{3} / \mathrm{dia}\right)$ & 140 \\
\hline Saída de Sedimentos Corrente $\left(\mathrm{m}^{3} / \mathrm{dia}\right)$ & 70 \\
\hline
\end{tabular}


As variáveis climáticas foram distribuídas ao longo de um ano, de acordo com os gráficos da Figura 6.43.
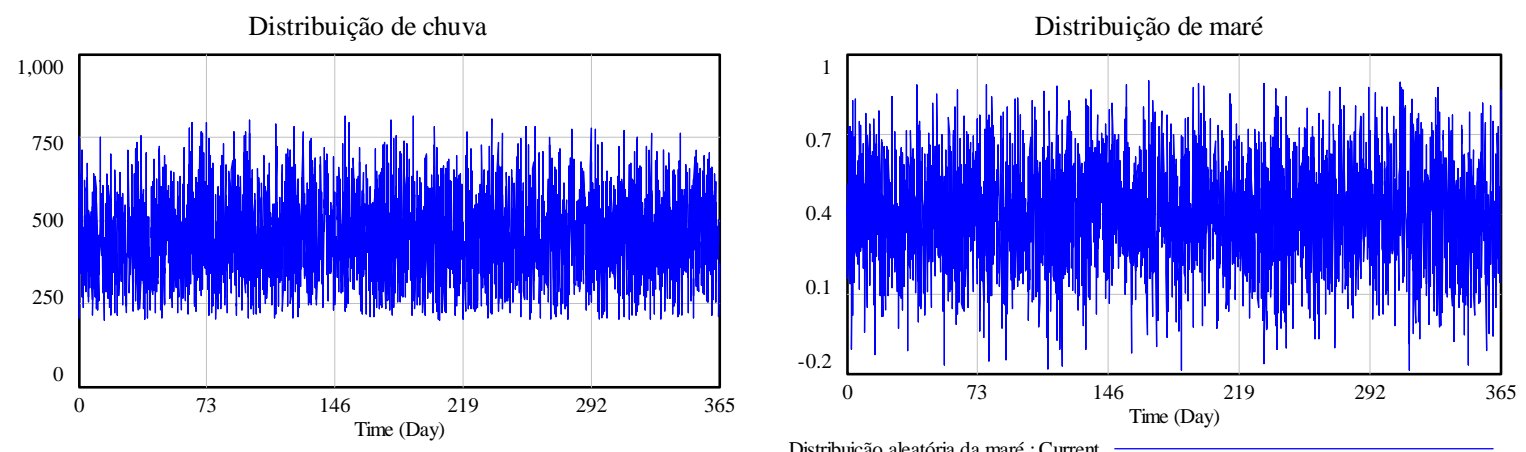

Distribuição aleatória da chuva : Current

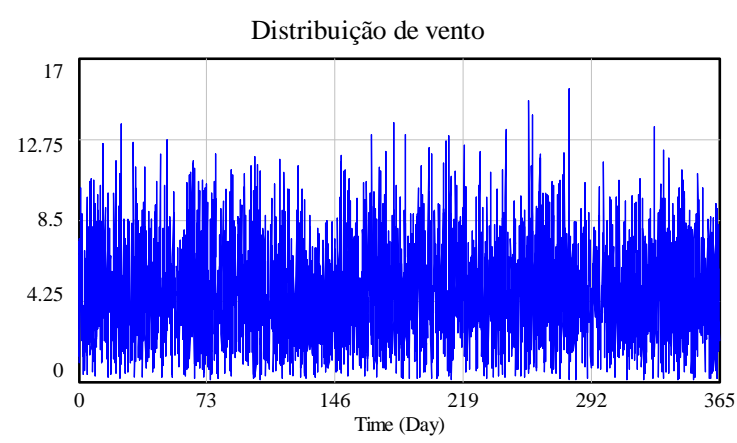

Figura 6.43 - Gráficos de distribuição das variáveis climáticas ao longo de um ano do cenário 1. A) Distribuição de chuva. B) Distribuição de maré. C) Distribuição de ventos.

A partir desses parâmetros, após 750 anos, obtiveram-se volumes de praia e duna iguais a $6.082 .500\left(6,08 \times 10^{6} \mathrm{~m}^{3}\right)$ e $13.080 .000\left(1,31 \times 10^{7} \mathrm{~m}^{3}\right)$, respectivamente (Fig.6.44).

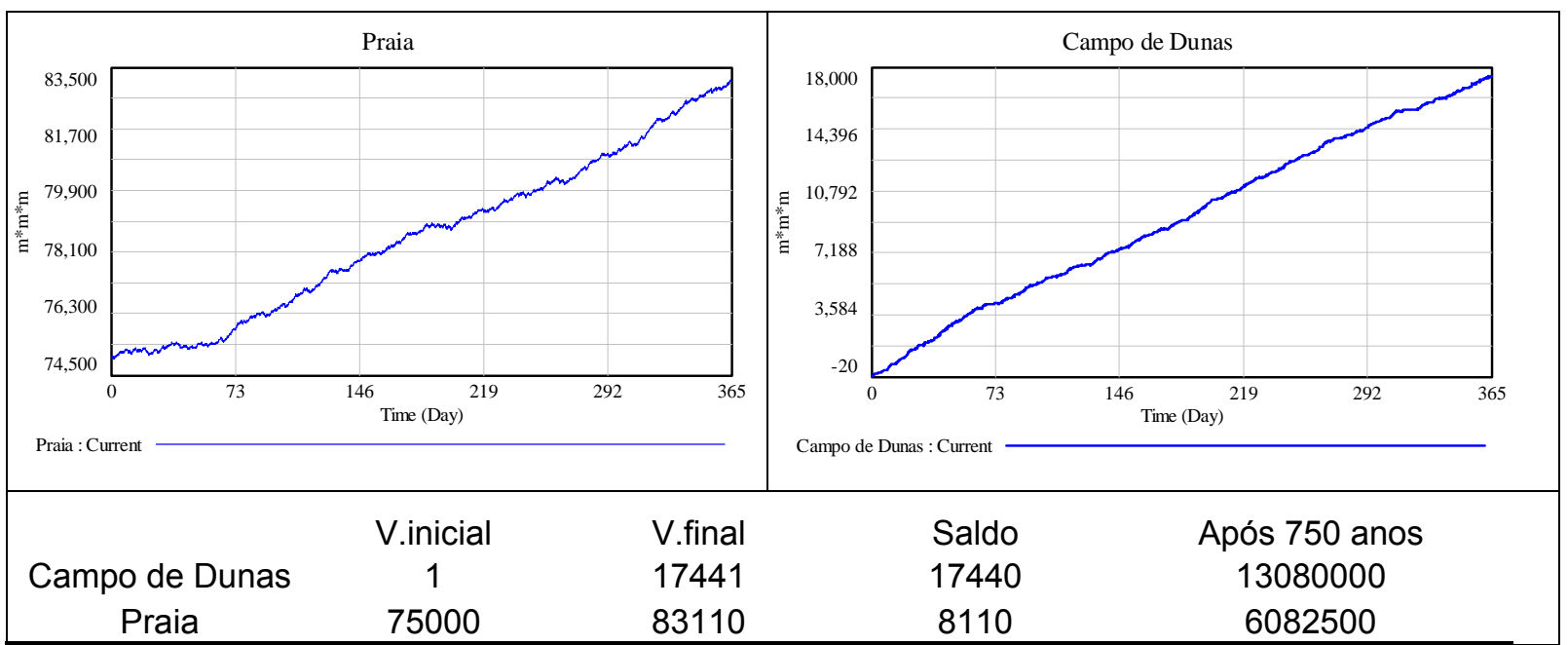

Figura 6.44 - Gráfico de acúmulo de volume de sedimentos ao longo de um ano do cenário 1 para clima úmido. Os valores correspondem ao acúmulo após 750 anos.

Os mesmos parâmetros foram simulados para períodos de clima ameno, sendo que foram obtidos volumes de praia e campo de dunas iguais a $637.500\left(6,38 \times 10^{5} \mathrm{~m}^{3}\right)$ e $18.525 .000\left(1,85 \times 10^{7} \mathrm{~m}^{3}\right)$ respectivamente (Fig.6.45). Observa-se então que este cenário climático é mais favorável ao desenvolvimento de dunas e desfavorável à progradação dos 
cordões litorâneos, com pulsos de erosão e sedimentação de maiores amplitudes para a praia.

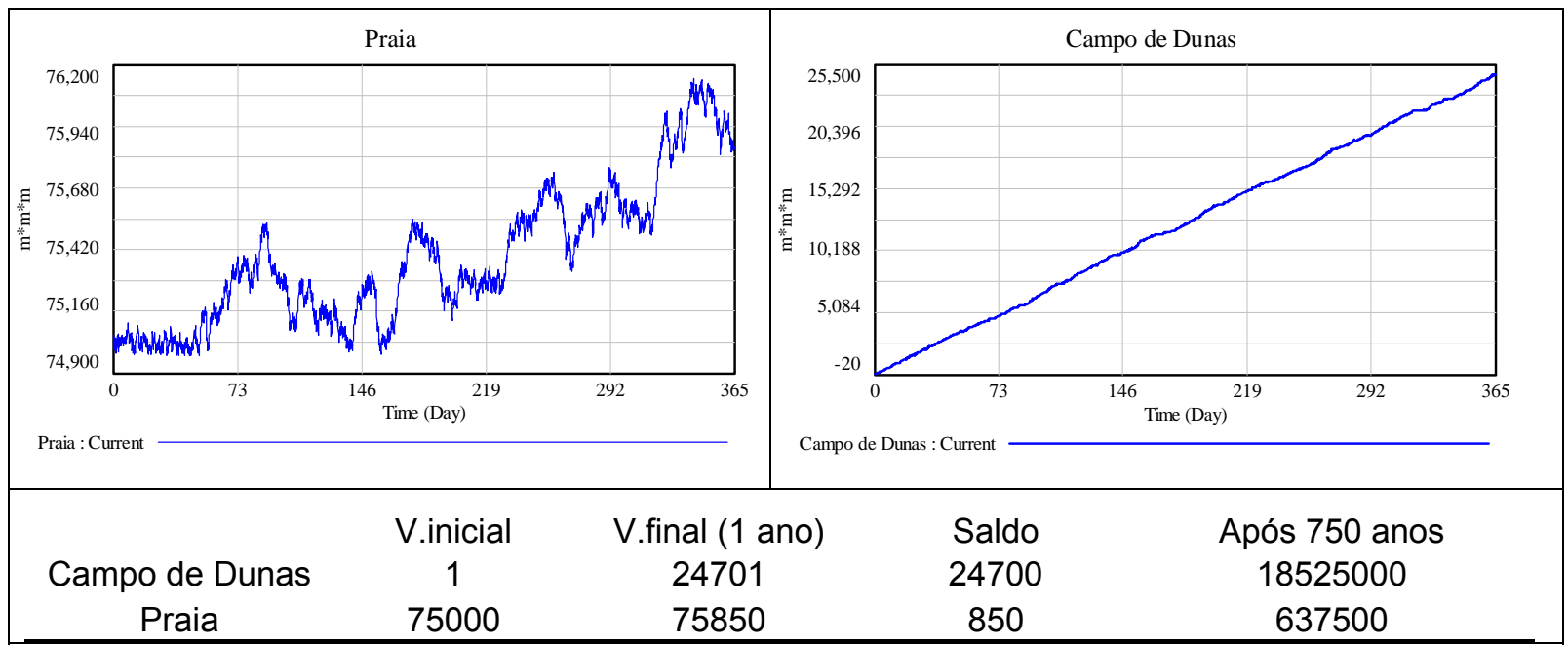

Figura 6.45 - Gráfico de acúmulo de volume de sedimentos ao longo de um ano do cenário 1 para período com clima ameno. Os valores correspondem ao acúmulo após 750 anos.

Em períodos mais secos, os mesmos parâmetros iniciais resultariam com volumes de praia e campo de dunas iguais a $18.750\left(1,88 \times 10^{4} \mathrm{~m}^{3}\right)$ e $19.143 .750\left(1,91 \times 10^{7} \mathrm{~m}^{3}\right)$ respectivamente (Fig.6.46). Observa-se então que condições mais secas (de menor precipitação) favorecem o desenvolvimento de dunas e desfavorecem a progradação dos cordões litorâneos; neste caso, a progradação/crescimento da praia segue um padrão não linear, imprevisível em escala anual.

Para formar as dunas sob condições úmidas, é necessário alto fluxo eólico, ligado a disponibilidade de sedimentos e velocidade dos ventos suficientes para o transporte dos grãos. Desse modo, pode-se afirmar que alto fluxo eólico deve ser estabelecido para atingir as condições atuais de desenvolvimento de campo de dunas, em vista da condição vigente de clima úmido.

Arens (1996) discute a respeito da taxas de transporte eólico relacionadas a condições meteorológicas em duas praias da Holanda. Segundo o autor, os movimentos mais fortes de areia são observados durante dias com chuva forte porém de curta duração, quando o impacto da gota de chuva serve como gatilho para dispersar os grãos. Essa afirmação é confirmada por Sarre (1989) e De Lima et al. (1992). Aparentemente, o aumento da capacidade de transporte ocasionado pela chuva é limitado a curtos períodos, porém quando a chuva é contínua, a superfície fica encharcada e a força de coesão entre os grãos de areia aumenta (Arens 1996). A simulação aqui desenvolvida não contempla a escala de horas, portanto não pôde ser testada a situação em que a chuva tenha duração limitada a poucos minutos, como evocado por Arens (1996); diferentemente, na situação simulada ou há chuva ou não há chuva durante um determinado dia. Apesar disso, é possível observar que, mesmo 
em períodos chuvosos, pode ocorrer desenvolvimento de dunas, desde que haja aumento da taxa de transporte (fluxo eólico).

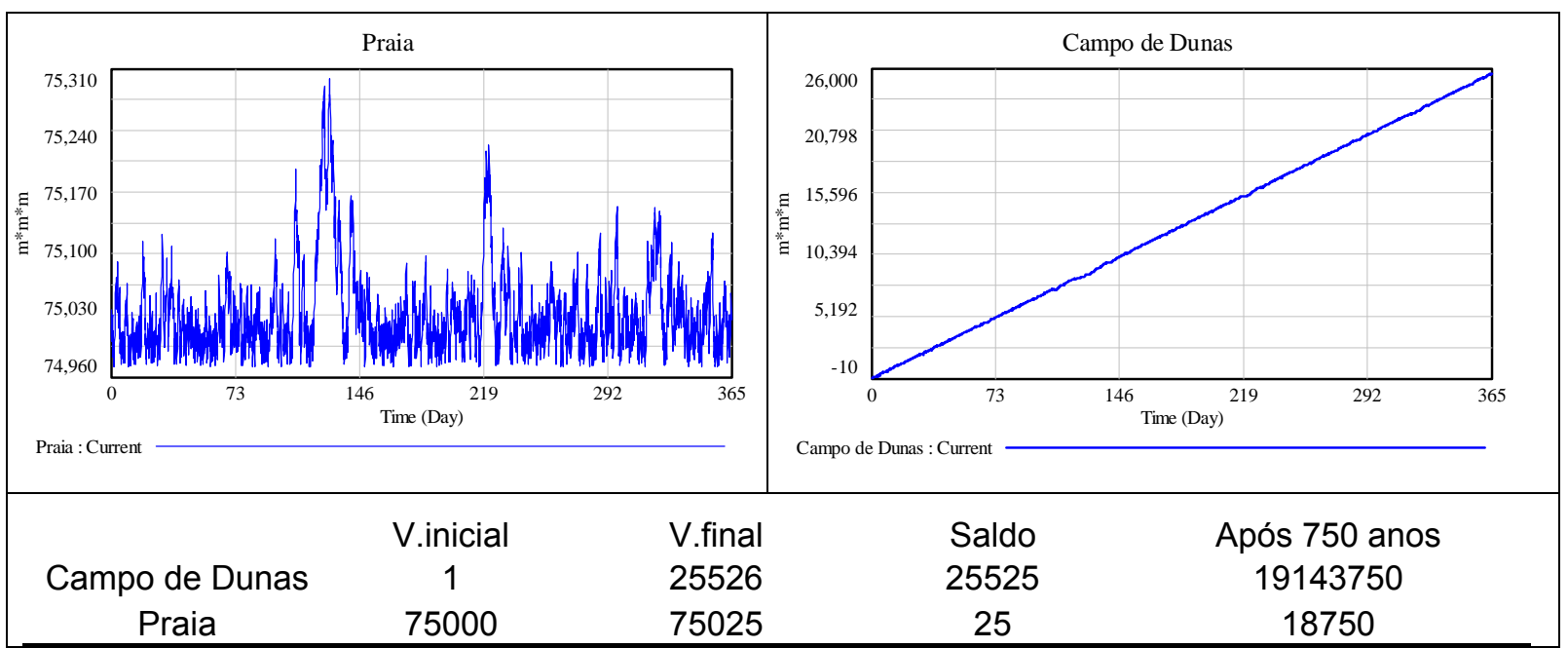

Figura 6.46 - Gráfico de acúmulo de volume de sedimentos ao longo de um ano do cenário 1 para período seco. Os valores correspondem ao acúmulo após 750 anos.

CENÁRIO 2) O cenário 2 compreende a calibração dos dados para o período de clima seco, com regime de chuvas semelhante ao do trimestre junho-julho-agosto. Para a simulação, foram considerados parâmetros apresentados nas Tabelas 6.12 e 6.13 .

Tabela 6.12 - Parâmetros climáticos utilizados para simular cenário de clima seco.

\begin{tabular}{|c|c|c|c|c|c|c|}
\hline Distribuições Aleatórias & Minímo & Máximo & Médio & D.padrão & Semente & Limite \\
\hline Chuva $(\mathrm{mm})$ & 147 & 818 & 339 & 131 & 2010 & 400 \\
\hline Maré $(\mathrm{m})$ & $-0,2$ & 0,9 & 0,4 & 0,2 & 2010 & 0,8 \\
\hline Velocidade do vento $(\mathrm{m} / \mathrm{s})$ & 0,10 & 16,00 & 3,94 & 3,34 & 2010 & 2,76 \\
\hline
\end{tabular}

Tabela 6.13 - Parâmetros inicias de estoque e fluxo para simular o cenário 2 do sistema praia-duna

\begin{tabular}{|c|c|}
\hline Modelo (período seco) & Condições Iniciais \\
\hline Estoque Praia $\left(\mathrm{m}^{3}\right)$ & 75000 \\
\hline Estoque Campo de Dunas $\left(\mathrm{m}^{3}\right)$ & 1 \\
\hline Erosão $\left(\mathrm{m}^{3} / \mathrm{dia}\right)$ & 24 \\
\hline Fluxo Eólico $\left(\mathrm{m}^{3} / \mathrm{dia}\right)$ & 198 \\
\hline Entrada de Sedimentos Corrente $\left(\mathrm{m}^{3} / \mathrm{dia}\right)$ & 143 \\
\hline Saída de Sedimentos Corrente $\left(\mathrm{m}^{3} / \mathrm{dia}\right)$ & 70 \\
\hline
\end{tabular}

As variáveis climáticas ao longo de um ano foram distribuídas segundo ilustrado pelos gráficos da Figura 6.47. 


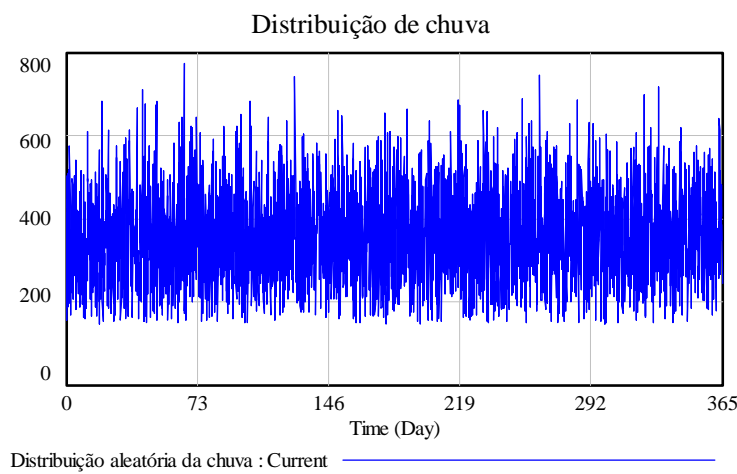

Distribuição aleatória da chuva : Current

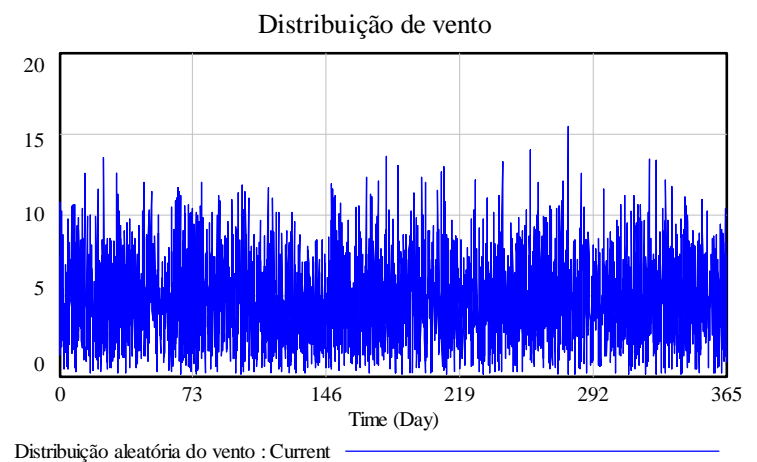

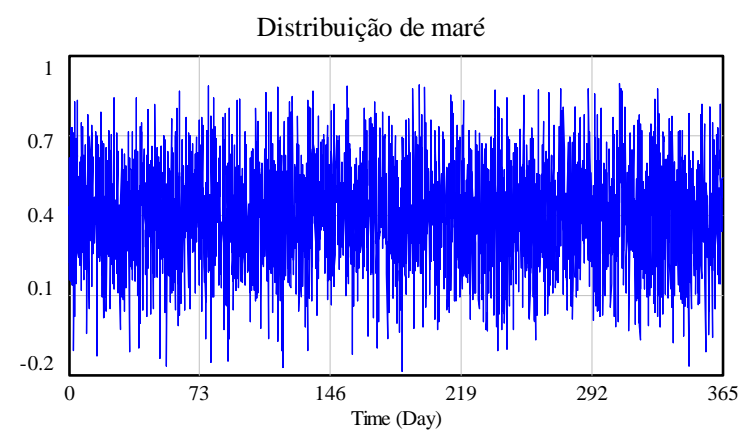

Distribuição aleatória da maré : Curren

Figura 6.47 - Gráficos de distribuição das variáveis climáticas ao longo de um ano do cenário 2. A) Distribuição de chuva. B) Distribuição de maré. C) Distribuição de ventos.

A partir desses parâmetros, após 750 anos, obtiveram-se volumes de praia e duna de 5.967.997 $\left(5,97 \times 10^{6} \mathrm{~m}^{3}\right)$ e $14.015 .850\left(1,40 \times 10^{7} \mathrm{~m}^{3}\right)$, respectivamente (Fig.6.48).

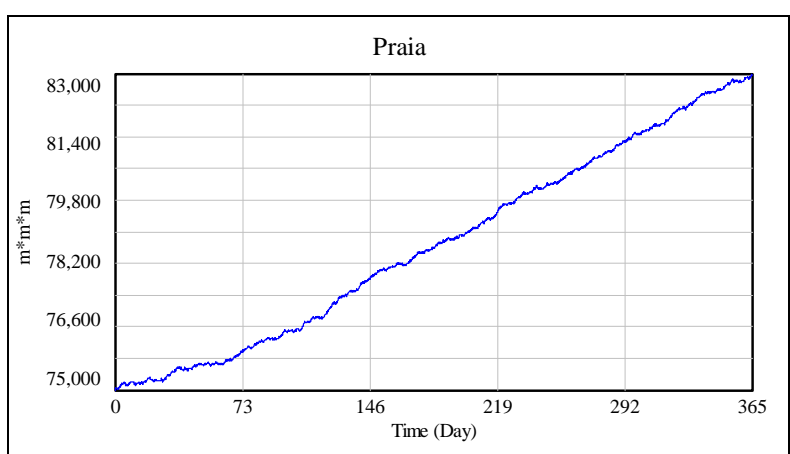

Praia : Current

V.inicial

Campo de Dunas

Praia
1

75000

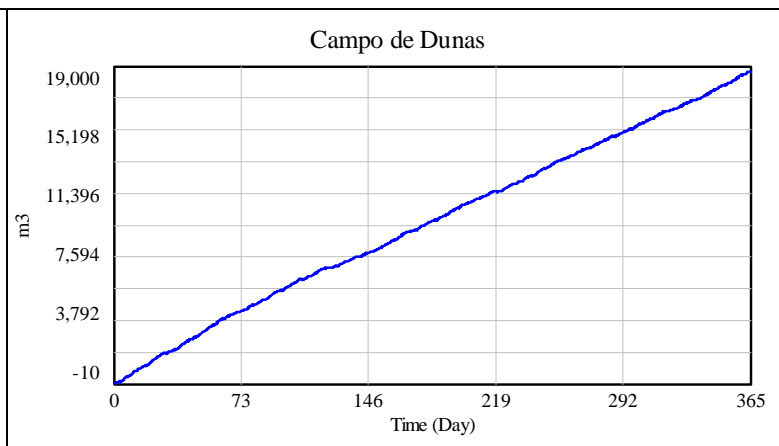

Campo de Dunas : Current

Saldo
18687,8
7957,33

\section{Após 750 anos \\ 14015850 \\ 5967997,5}

Figura 6.48 - Gráfico de acúmulo de volume de sedimentos ao longo de um ano do cenário 2 para clima seco. Os valores correspondem ao acúmulo após 750 anos.

Os mesmos parâmetros foram simulados para períodos amenos, de modo que foram obtidos volumes de praia e campo de dunas iguais a $9.152 .475\left(9,15 \times 10^{6} \mathrm{~m}^{3}\right)$ e 10.831 .350 $\left(1,08 \times 10^{7} \mathrm{~m}^{3}\right)$, respectivamente (Fig.6.49). Esta situação é mais favorável ao desenvolvimento de dunas e propícia, porém menos favorável, à progradação dos cordões litorâneos. 


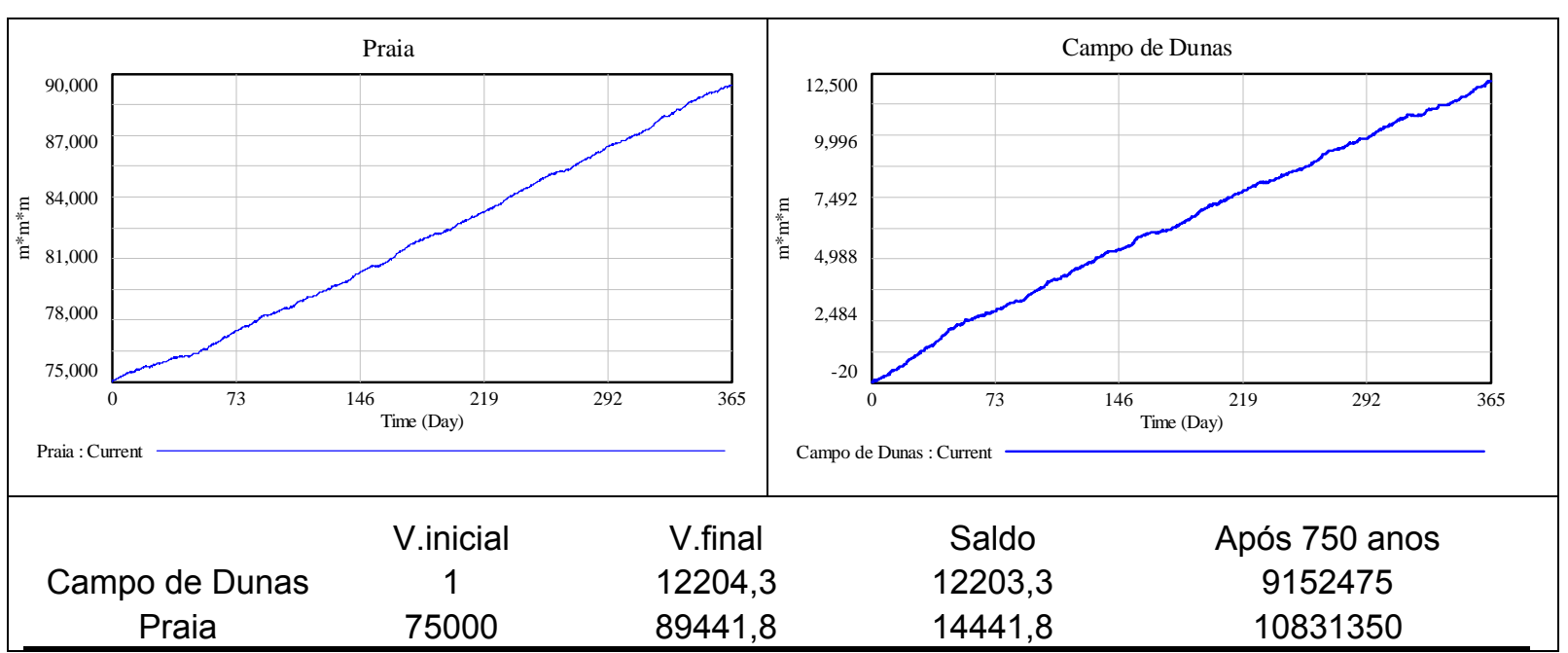

Figura 6.49 - Gráfico de acúmulo de volume de sedimentos ao longo de um ano do cenário 2 para período ameno. Os valores correspondem ao acúmulo após 750 anos.

Em períodos mais úmidos, os mesmos parâmetros iniciais resultariam em volumes de praia e campo de dunas iguais a $14.599 .500\left(1,46 \times 10^{7} \mathrm{~m}^{3}\right)$ e $5.384 .250\left(5,38 \times 10^{6} \mathrm{~m}^{3}\right)$, respectivamente (Fig.6.50). Observa-se que esta situação é menos favorável ao desenvolvimento de dunas e mais favorável a progradação dos cordões litorâneos.

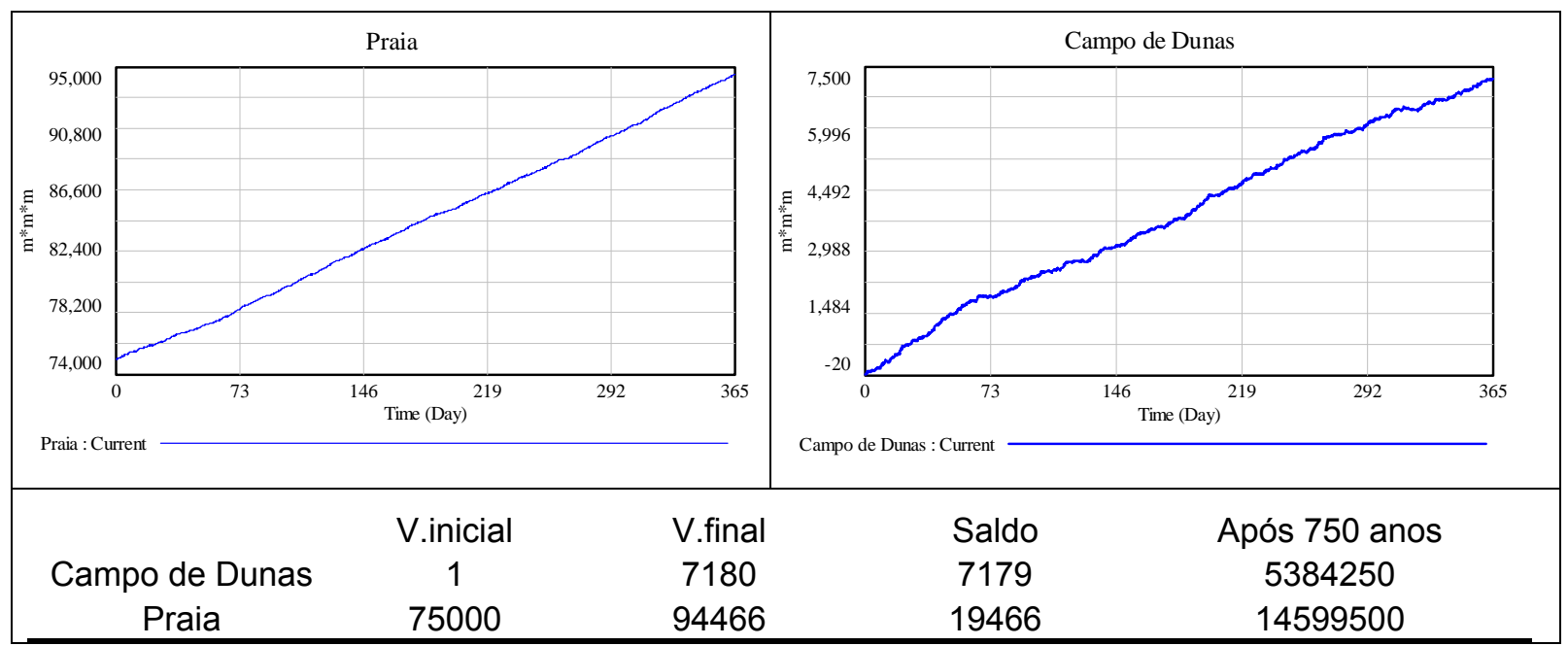

Figura 6.50 - Gráfico de acúmulo de volume de sedimentos ao longo de um ano do cenário 2 para período úmido. Os valores correspondem ao acúmulo após 750 anos.

Observa-se que, na simulação para clima seco representada pelo cenário 2 , há tanto desenvolvimento de dunas a taxas (fluxo eólico) menores que para o cenário 1 como também progradação da praia, no período úmido.

CENÁRIO 3) O cenário 3 compreende a calibração dos dados para o período de clima com taxa de precipitação intermediária, representado por regime de chuvas semelhante ao do trimestre agosto-setembro-outubro na região. Para a simulação, foram considerados parâmetros apresentados nas Tabelas 6.14 e 6.15 . 
Tabela 6.14 - Parâmetros climáticos utilizados para simular cenário de clima com precipitação intermediária.

\begin{tabular}{|c|c|c|c|c|c|c|}
\hline Distribuições Aleatórias & Mínimo & Máximo & Médio & D.padrão & Semente & Limite \\
\hline Chuva $(\mathrm{mm})$ & 114 & 686 & 404 & 141 & 2010 & 400 \\
\hline Maré $(\mathrm{m})$ & $-0,2$ & 0,9 & 0,4 & 0,2 & 2010 & 0,8 \\
\hline Velocidade do vento $(\mathrm{m} / \mathrm{s})$ & 0,10 & 16,00 & 3,94 & 3,34 & 2010 & 2,76 \\
\hline
\end{tabular}

Tabela 6.15 - Parâmetros inicias de estoque e fluxo para simular o cenário 3 do sistema praia-duna.

\begin{tabular}{|c|c|}
\hline Modelo (período ameno) & Condições Iniciais \\
\hline Estoque Praia $\left(\mathrm{m}^{3}\right)$ & 75000 \\
\hline Estoque Campo de Dunas $\left(\mathrm{m}^{3}\right)$ & 1 \\
\hline Erosão $\left(\mathrm{m}^{3} / \mathrm{dia}\right)$ & 24 \\
\hline Fluxo Eólico $\left(\mathrm{m}^{3} / \mathrm{dia}\right)$ & 260 \\
\hline Entrada de Sedimentos Corrente $\left(\mathrm{m}^{3} / \mathrm{dia}\right)$ & 145 \\
\hline Saída de Sedimentos Corrente $\left(\mathrm{m}^{3} / \mathrm{dia}\right)$ & 71 \\
\hline
\end{tabular}

As variáveis climáticas ao longo de um ano foram distribuídas segundo o ilustrado na Figura 6.51.

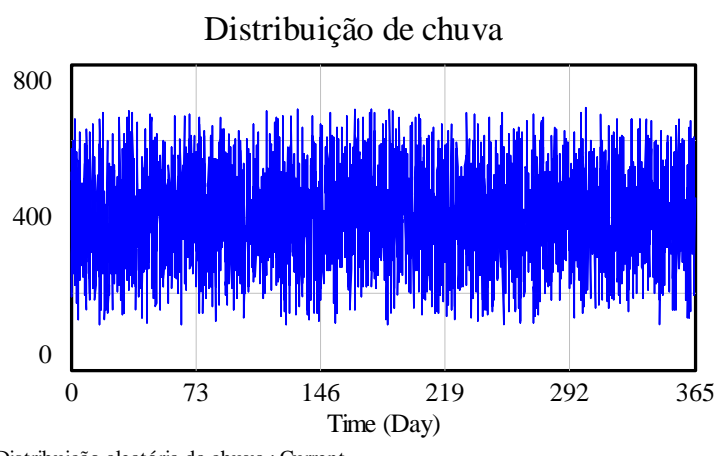

Distribuição aleatória da chuva : Current

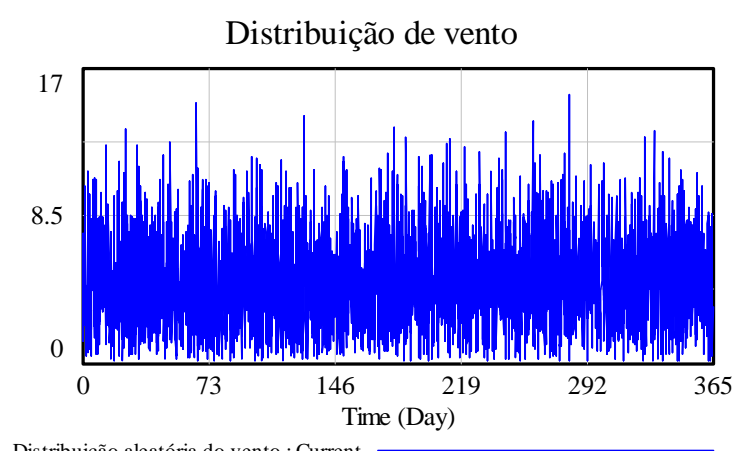

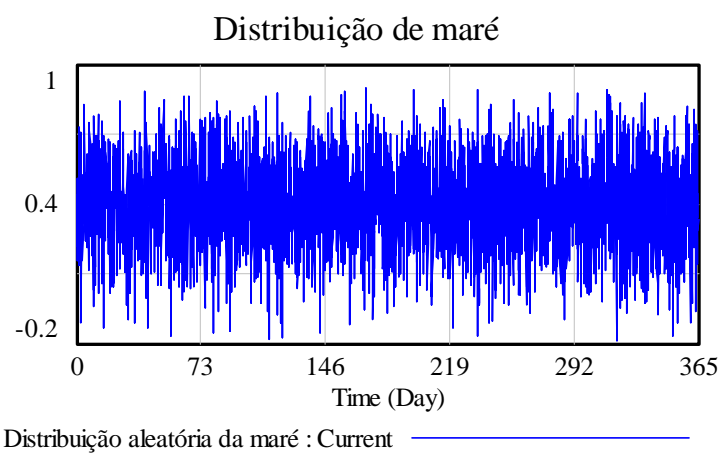

Figura 6.51 - Gráficos de distribuição das variáveis climáticas ao longo de um ano, no cenário 3. A) Distribuição de chuva. B) Distribuição de maré. C) Distribuição de ventos.

A partir desses parâmetros, após 750 anos, obtiveram-se volumes de praia e duna de 6.181.875 $\left(6,18 \times 10^{6} \mathrm{~m}^{3}\right)$ e 14.075.625 $\left(1,41 \times 10^{7} \mathrm{~m}^{3}\right)$, respectivamente (Fig.6.52). 


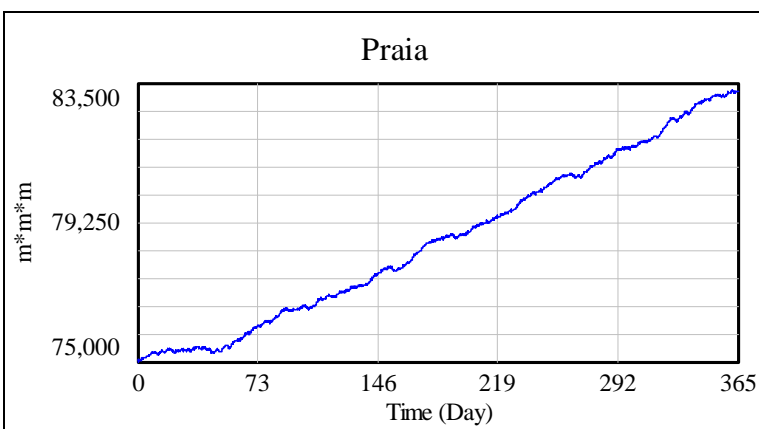

Praia : Current

$\begin{array}{ccc} & \text { V.inicial } & \text { V.final } \\ \text { Campo de Dunas } & 1 & 18768,5 \\ \text { Praia } & 75000 & 83242,5\end{array}$

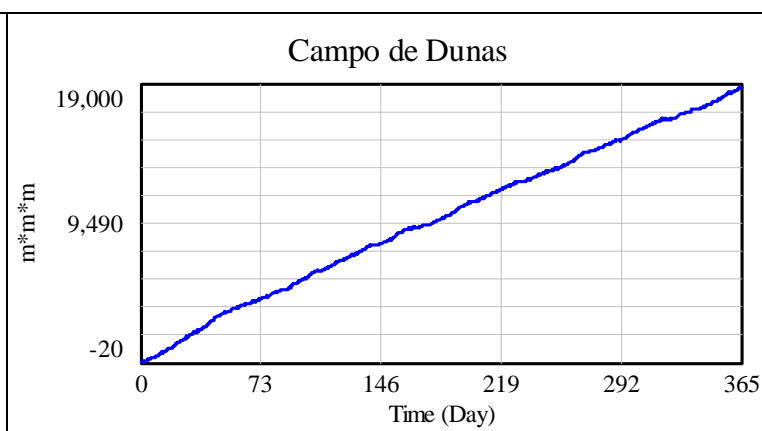

Campo de Dunas : Current

Saldo
18767,5
8242,5

Após 750 anos
14075625
6181875

Figura 6.52 - Gráfico de acúmulo de volume de sedimentos ao longo de um ano do cenário 3, para clima com pluviosidade intermediária. Os valores correspondem ao acúmulo após 750 anos.

Os mesmos parâmetros foram simulados para períodos mais úmidos, para os quais se obtiveram volumes de praia e campo de dunas iguais a $11.130 .000\left(1,11 \times 10^{7} \mathrm{~m}^{3}\right) \mathrm{e}$ $9.127 .500\left(9,13 \times 10^{6} \mathrm{~m}^{3}\right)$, respectivamente (Fig.6.53). Observa-se então que tal situação é menos favorável ao desenvolvimento de dunas e mais propícia à progradação dos cordões litorâneos, em comparação com a anterior.

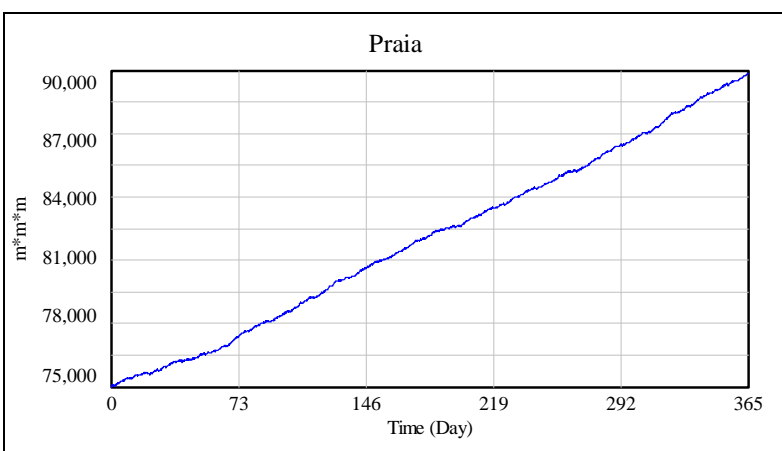

Praia : Current

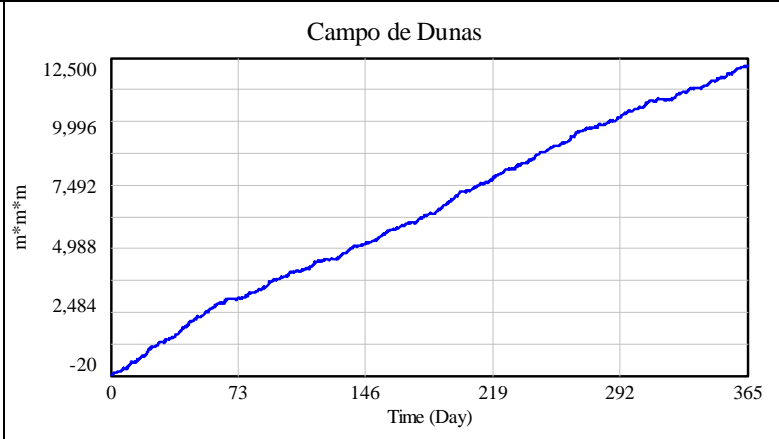

Campo de Dunas : Current

\section{Após 750 anos \\ 11130000 \\ 9127500}

Campo de Dunas

1

12171

12170

Figura 6.53 - Gráfico de acúmulo de volume de sedimentos ao longo de um ano do cenário 3, para período úmido. Os valores correspondem ao acúmulo após 750 anos.

Em períodos mais secos, os mesmos parâmetros iniciais resultariam em volumes de praia e campo de dunas iguais a $648.750\left(6,5 \times 10^{5} \mathrm{~m}^{3}\right)$ e $19.608 .750\left(1,96 \times 10^{7} \mathrm{~m}^{3}\right)$, respectivamente (Fig.6.54). Observa-se que esta situação seria favorável ao desenvolvimento de dunas e desfavorável à progradação dos cordões litorâneos. Nesta situação, o padrão não linear de crescimento da praia torna-se imprevisível em escala anual. 


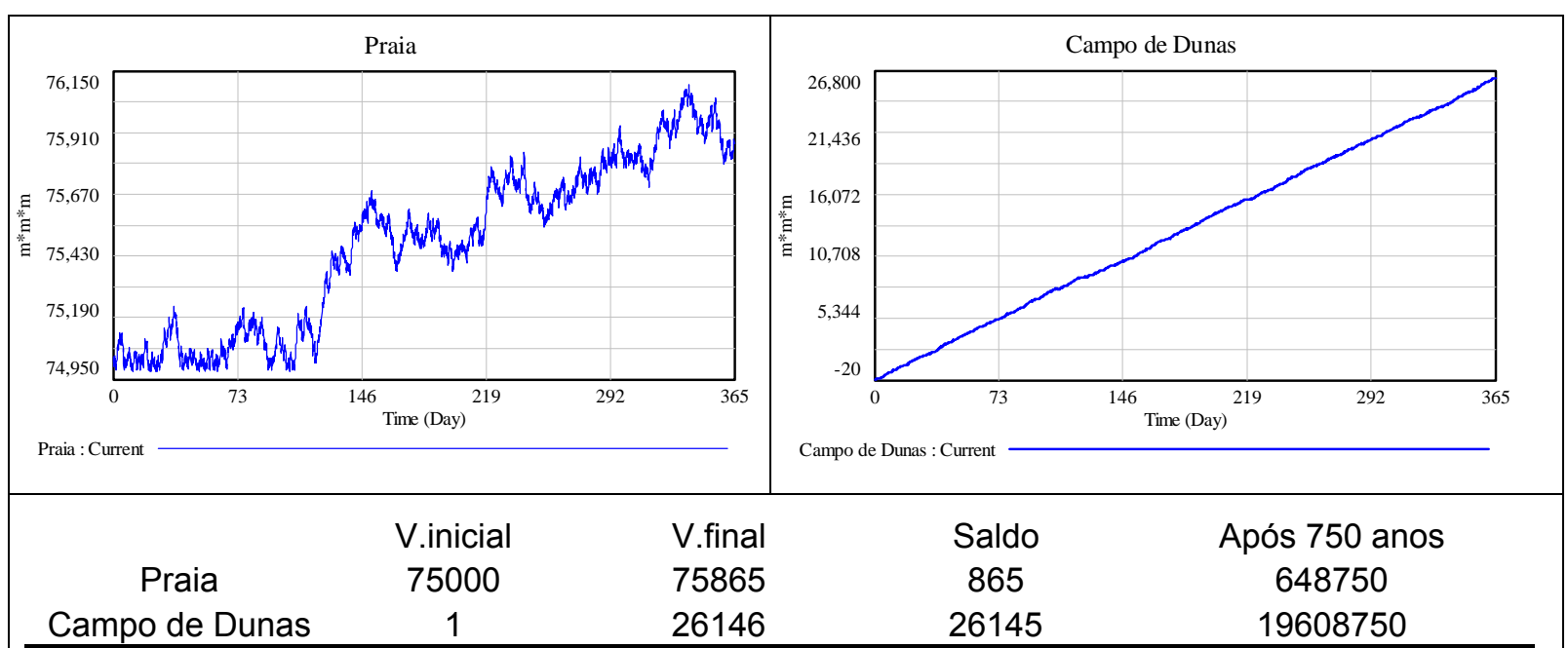

Figura 6.54 - Gráfico de acúmulo de volume de sedimentos ao longo de um ano do cenário 3 para período seco. Os valores correspondem ao acúmulo após 750 anos.

As planícies de Campos Verdes e do Ji foram formadas ao longo do Holoceno médio e tardio possivelmente sob contexto de clima progressivamente mais úmido (Behling 1995, Cruz et al. 2007, Amaral 2008, Wanner et al. 2008), sendo que o cenário 1 melhor se enquadra a esta situação, porém com flutuações climáticas; em outras palavras, a situação ideal para formar o cenário real observado atualmente na planície do Ji seria intercalar períodos secos, amenos e úmidos num contexto geral de clima progressivamente mais úmido. São necessárias futuras implementações e simulações do modelo, como mudanças climáticas sazonais, ou ainda em escala de tempo de horas.

\section{CONCLUSÕES}

As conclusões, apresentadas a seguir em tópicos, corroboram e complementam modelos de evolução sedimentar previamente apresentados para as planícies de Campos Verdes e do Ji. Ao final deste capítulo, as evoluções sedimentares simplificadas são ilustradas esquematicamente na forma de quadrinhos (Fig.7.1 a 7.3).

1) Foram delimitados 14 feixes de cordões litorâneos em Campos Verdes, com idade decrescente de sul para norte, e cinco feixes de alinhamentos de cordões concordantes no Ji, com idade decrescente de oeste para leste.

2) Em furo de sondagem de $12,5 \mathrm{~m}$, realizado em Campos Verdes, a passagem ascendente de areia lamosa para areia fina caracteriza registro regressivo em escala mais ampla: o intervalo inferior corresponderia à fase de inundação, formando uma baía e depois uma baía-laguna; e o superior seria o registro vertical de clinoformas progradantes, formadas sob NRM ligeiramente declinante e que, em superfície, formam os cordões litorâneos. 
3) A variação combinada de medidas granulométricas "mais fino, melhor selecionado e mais negativo" encontrada em perfil transversal aos cordões e dunas eólicas de Campos Verdes, é um padrão indicador de retrabalhamento sedimentar seletivo durante a progradação para norte. Em perfil longitudinal, observa-se outro padrão indicador de transporte sedimentar, "mais grosso, melhor selecionado e mais positivo" para oeste, neste caso relacionado à deriva litorânea longitudinal e/ou ao domínio de fluxo de enchente na sedimentação.

4) Os vetores aceitos no programa GSTAST indicaram retrabalhamento progressivo dos sedimentos de Campos Verdes para N, com um vetor para NE.

5) O padrão "mais grosso, melhor selecionado e mais positivo" encontrado em perfil transversal aos cordões do Ji, para leste, reflete o crescimento geral da planície nesse rumo, e pode ser atribuído a sucessivo retrabalhamento sedimentar. Mesmo padrão indicador de transporte foi encontrado em perfil longitudinal, rumo $\mathrm{N}$, variação que pode ser atribuída ao efeito da corrente de deriva litorânea residual para NNE.

6) Os vetores aceitos no programa GSTAST, aplicado à planície do Ji, indicaram transporte para $\mathrm{E}$ e NE, atribuído ao efeito combinado do retrabalhamento progradacional, para $\mathrm{E}$, com o transporte preferencial longitudinal, para NNE, este devido à deriva litorânea longitudinal vigente na época de formação dos cordões.

7) Os gradientes baixos de estatísticas descritivas da granulometria para as amostras de duna eólica e cordão em Campos Verdes indicam elevada homogeneidade textural, explicada pela atuação dos cordões como fonte imediata das dunas e vice-versa. Já na planície do Ji, observa-se maior distinção entre os sedimentos de cordão e duna eólica, o que se explica pelas maiores distâncias de avanço dos campos de dunas.

8) Quando se comparam sedimentos de cordões das duas planícies quanto à granulometria, nota-se, apesar da grande semelhança, ligeira diferença no desvio padrão, mais elevado (pior seleção) no Ji que em Campos Verdes.

9) As amostras de margem-pontal lagunar são mais grossas e pior selecionadas que as demais, com assimetria mais negativa e curtose elevada. Essa diferença pode ser explicada devido ao menor retrabalhamento dessa porção da planície de Campos Verdes, onde foi a primeira a se formar.

10) Ressalta-se a maior freqüência de minerais instavéis (iINS) em relação a ultraestáveis (iZTR) no norte da planície de Campos Verdes e a tendência geral de queda de maturidade mineralógica rumo $\mathrm{N}$ e NE. Esse padrão pode ser explicado por três hipóteses distintas: i) mudança de fonte com maior aporte de sedimentos "novos", ricos em instáveis (principalmente hornblenda), no setor norte, através do aporte relacionado ao rio Tubarão, ii) concentração progressiva, por seleção hidráulica durante o retrabalhamento progradacional, iii) maior tempo de atuação da dissolução pós-deposicional na porção sudoeste. 
11) $O$ aumento do iTZ rumo $N$, em Campos Verdes, reforça a hipótese de controle hidráulico na variação espacial da mineralogia. O aumento para norte do iHT é coerente com a hipótese de menor tempo de atuação da dissolução pós-deposicional, porém pode ser usada, no presente caso, de maneira mais segura como argumento a favor da hipótese de influência crescente ao longo do tempo (para norte) da frente deltaica do rio Tubarão.

12) Na planície do Ji, ressalta-se a maior freqüência de componentes instavéis (ilNS) e metaestáveis (iMET) em relação aos ultraestáveis (iZTR) na porção mais externa da planície, com tendência geral de queda de maturidade para $E$.

13) O aumento do iTZ rumo $E$, no Ji, reforça a hipótese de controle hidráulico na variação espacial da mineralogia. O aumento do iHT para E é coerente com a hipótese de aumento de aporte de sedimentos ricos em hornblenda, no decorrer da progradação, e/ou menor tempo de atuação da dissolução pós-deposicional.

14) A variação entre as freqüências dos índices de minerais pesados obtidos para fácies diferentes da mesma planície é menor do que a variação observada para a mesma fácies entre planícies diferentes. Isso permite concluir que os índices de minerais pesados neste estudo de caso são mais sensíveis a fatores de controle geográfico que faciológico.

15) No geral, os sedimentos da planície do Ji são mais imaturos mineralogicamente que os de Campos Verdes (clriNS mais elevado e clrZTR mais baixo).

16) Os maiores valores de iTZ em Campos Verdes, em relação aos do Ji podem relacionar-se ao contraste entre as planícies quanto às condições de transporte e retrabalhamento, ligado a seus respectivos contextos hidrodinâmicos, de retrobarreira versus de mar aberto.

17) $\mathrm{Na}$ análise de PCA, as amostras de Campos Verdes apresentam-se fortemente condicionadas a valores mais altos de clrZTR e iTZ. Já as do Ji estão condicionadas a valores maiores das variáveis mineralógicas clrINS e iHT. Constata-se novamente que as variáveis mineralógicas são mais sensíveis a fatores de controle geográfico ou local, que as variáveis granulométricas, estas condicionadas ou a fatores de atuação regional ou a intenso retrabalhamento, com homogeneização granulométrica herdada da área fonte.

18) A idade mais antiga obtida foi de $4912 \pm 270$ anos, para amostra de paleopontal arenoso, e a mais nova de $174 \pm 14$ anos, para paleoduna eólica, ambas em Campos Verdes.

19) No Ji, a idade mais antiga é de $2794 \pm 151$ anos e a mais recente é de $751 \pm 43$ anos, ambas para cordões litorâneos.

20) Foram definidos cinco estágios cronológicos de evolução para Campos Verdes: (1) desenvolvimento do pontal de retrobarreira antes de $4912 \pm 270$ anos AP; (2) crescimento dos primeiros cordões entre $4199 \pm 347$ e 2763 \pm 205 anos; (3) desenvolvimento das séries centrais de cordões entre $2763 \pm 205$ e 2816 \pm 193 anos; (4) formação das séries a norte entre

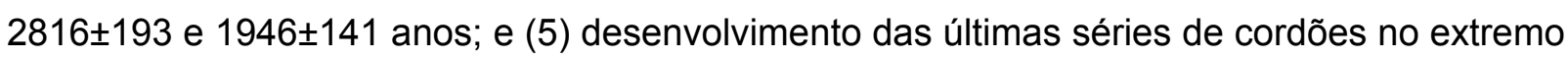




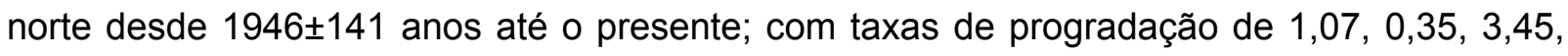
$0,76 \mathrm{~m} / \mathrm{a}$ e indeterminada, respectivamente.

21) Existem duas hipóteses para desenvolvimento das dunas eólicas em Campos Verdes, uma com a formação de cada grupo de dunas eólicas condicionada a uma série de cordões, com reativação deflacionar posterior, e outra de formação das dunas inteiramente durante o estágio evolutivo-cronológico 5; ambas as hipóteses pressupõem maior circulação dos ventos em períodos específicos, devido a mudanças climáticas de escala milenar.

22) Foram definidos cinco estágios cronológicos de evolução para o Ji: (1) início (estimado) da formação da primeira série de cordões litorâneos por volta de 5000 anos AP; (2) com desenvolvimento da segunda série entre $2794 \pm 151$ e $2537 \pm 140$ anos; (3) progradação das séries centrais entre $2537 \pm 140$ e $1031 \pm 35$; (4) entre $1031 \pm 35$ e $831 \pm 43$ anos; e (5) desenvolvimento dos cordões litorâneos paralelos a linha de costa atual desde $751 \pm 43$ anos até o presente; com taxas de progradação calculadas para os últimos quatro estágios de 2,26, 0,28, 1,47 e 1,24 m/a, respectivamente.

23) A estabilização das dunas da geração eólica 3 posicionadas no centro da planície do Ji teria ocorrido durante o estágio 3 , por volta de $1346 \pm 73$ anos.

24) O crescimento (taxas de progradação) das duas planícies estudadas ocorre em anti-fase devido a alternância entre duas situações, uma com predominância de ondas de SE e deriva litorânea rumo NE, associada a incursões mais freqüentes de frentes frias e massa de ar polar na região, e outra com domínio de ondas de NE e deriva litorânea rumo SW, com maior ação da massa tropical Atlântica. A primeira situação favorece a progradação no Ji e a segunda, em Campos Verdes.

25) Por volta de 2700 anos há um "boom" pontual na progradação de ambas as planícies (Campos Verdes, com 3,45 m/ano, e Ji, com 2,26 m/ano), o que pode estar relacionado a ocorrência de um dos eventos climáticos de escala milenar do Holoceno (Bond event 2) com aumento de umidade, precipitação e descarga fluvial.

26) O desenvolvimento/reativação das dunas de Campos Verdes pode estar em parte ligado a ocorrência de outro evento de escala milenar, a Pequena Idade do Gelo (aproximadamente 700 anos AP).

27) Em simulação, foram obtidos valores de fluxo eólico da ordem de $10^{4} \mathrm{~m}^{3} / a n o$, sendo que o desenvolvimento de campos de dunas extensos ( $6 \mathrm{~km}$ de extensão longitudinal) sob condições de precipitação elevada (média trimestral superior a $400 \mathrm{~mm}$ ) requer fluxos eólicos maiores ( $275 \mathrm{~m}^{3} /$ dia ou cerca de $\left.10^{5} \mathrm{~m}^{3} / \mathrm{ano}\right)$. 

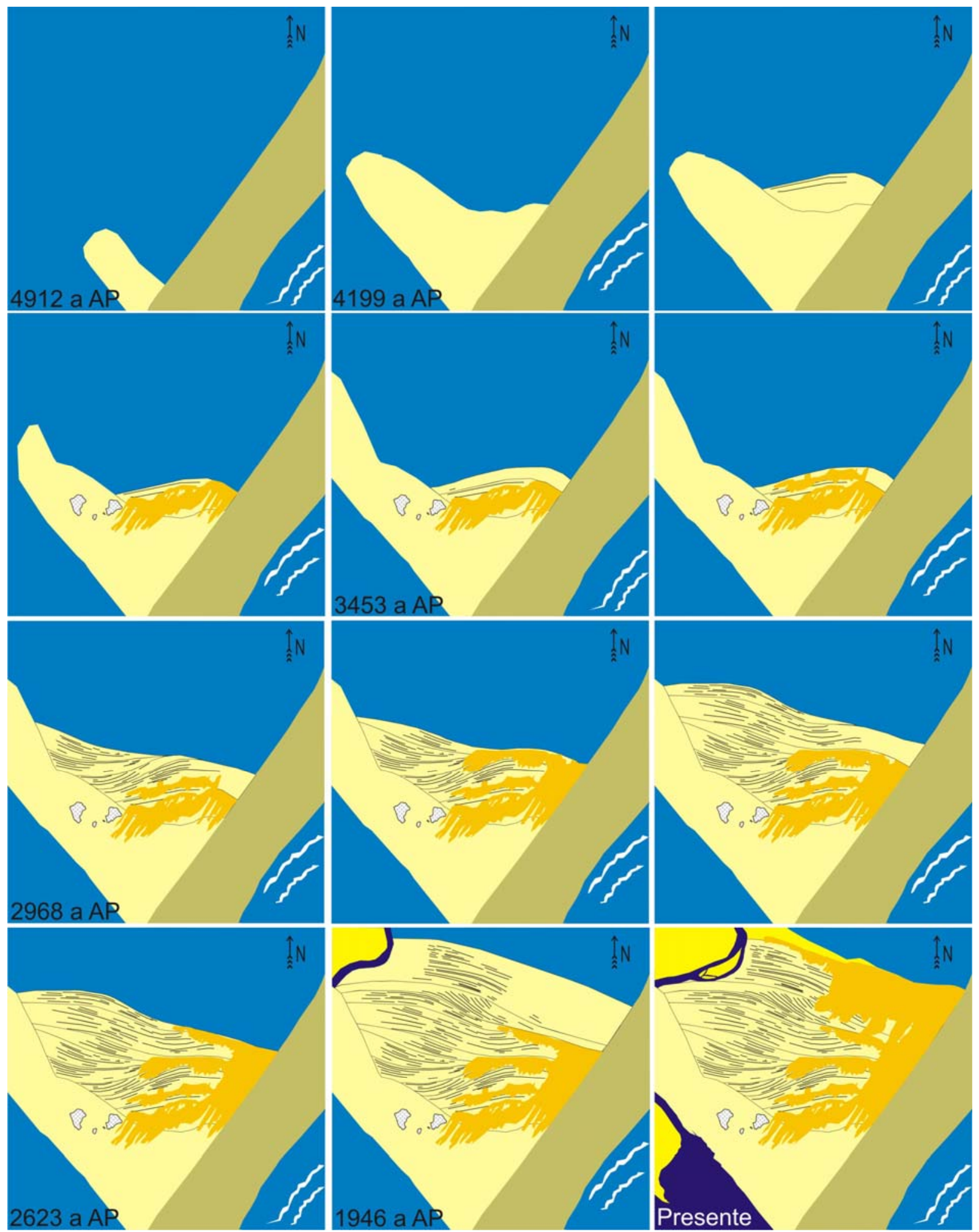

Figura 7.1 - Ilustração em etapas do modelo de evolução sedimentar da planície de Campos Verdes de acordo com a hipótese 1 (conclusão 21), de formação das dunas em pulsos, ligados aos hiatos de progradação, com reativação posterior (não representada no desenho). Cada quadro corresponde a um momento do desenvolvimento da planície (ordenados da esquerda para a direita e de cima para baixo). Adaptado de Tanaka et al. (2009a). 


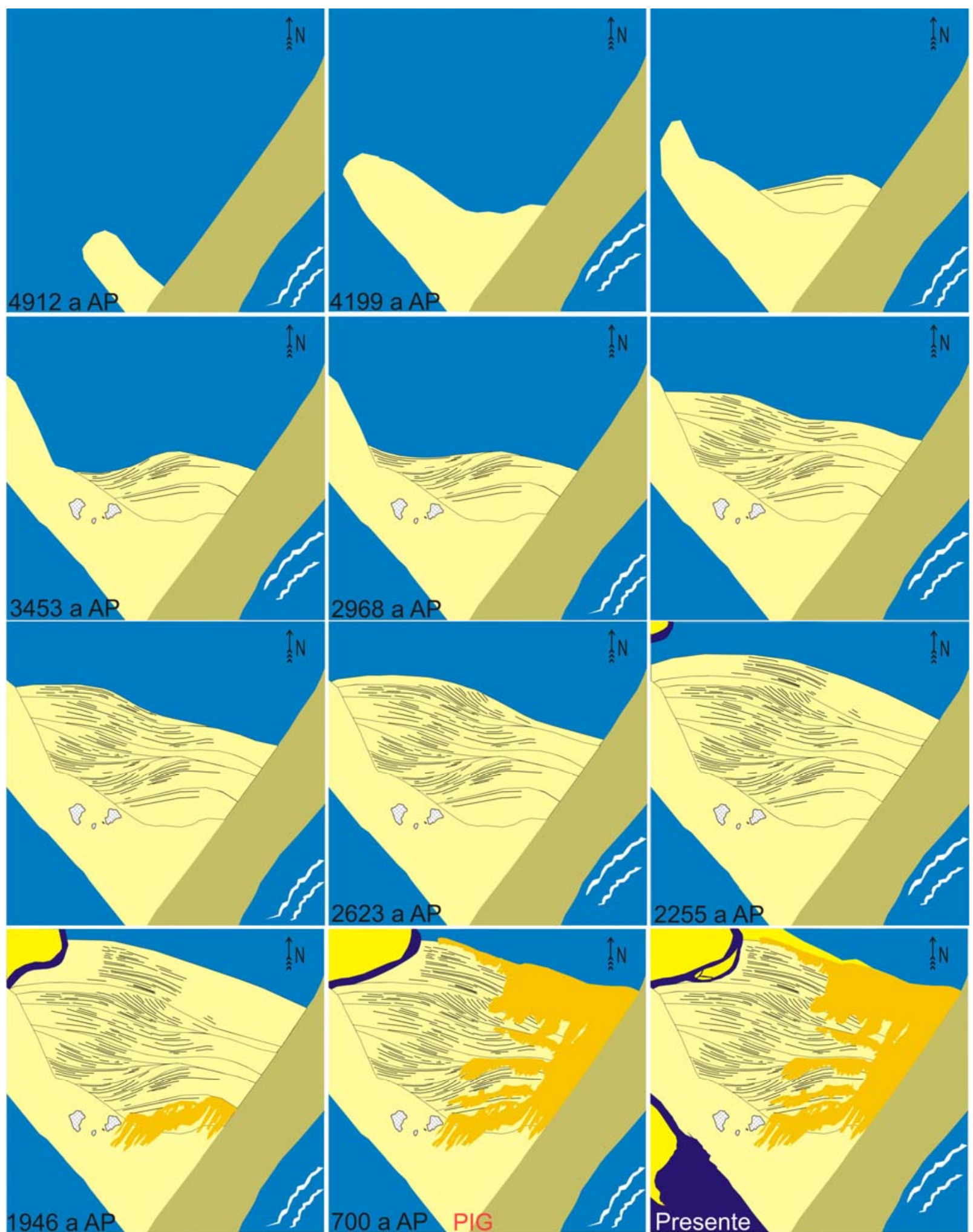

Figura 7.2 - llustração em etapas do modelo de evolução sedimentar da planície de Campos Verdes para a hipótese 2, com desenvolvimento de parte das dunas durante a Pequena Idade do Gelo (PIG). Cada quadro corresponde a um momento do desenvolvimento da planície (ordenados da esquerda para a direita e de cima para baixo). 


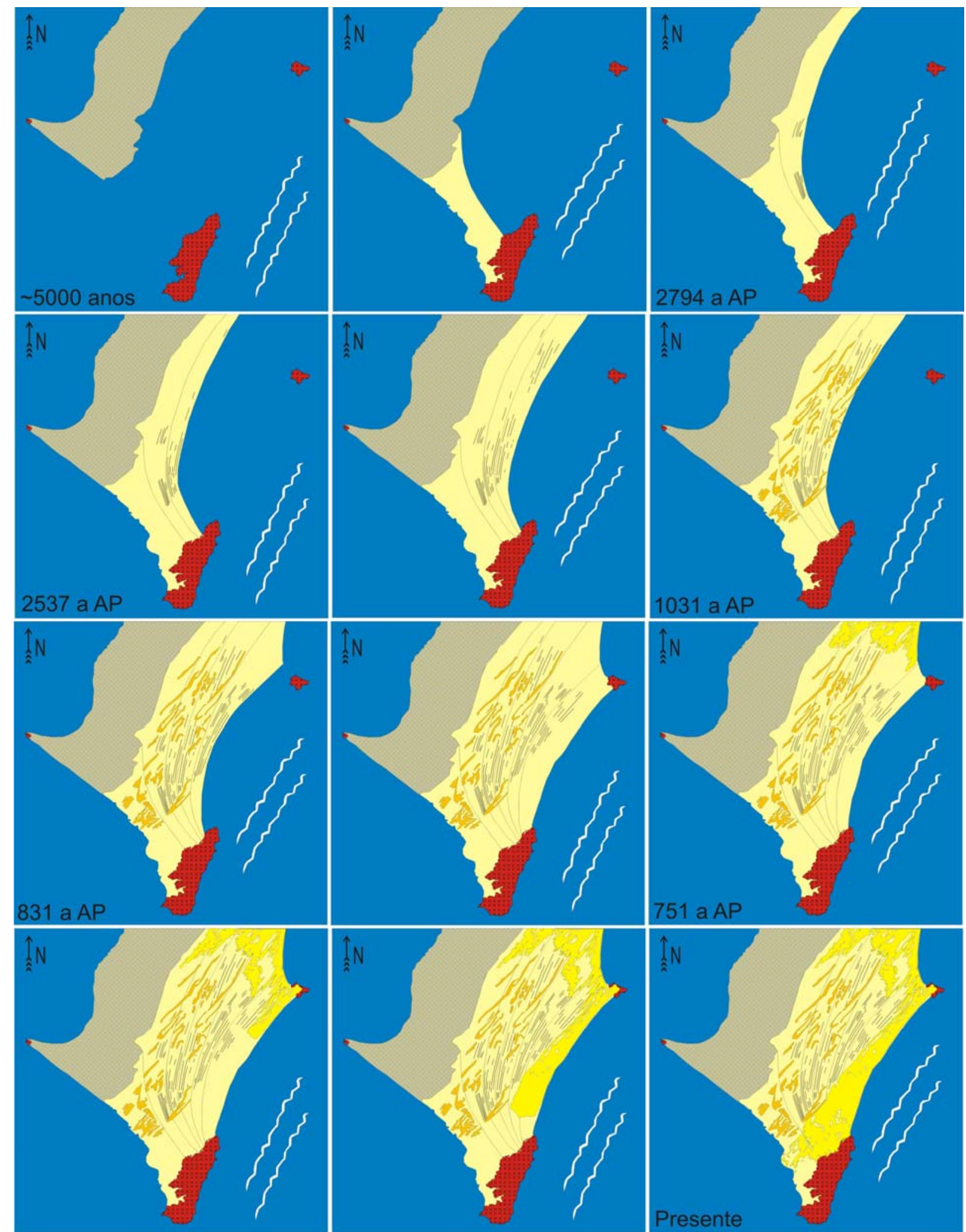

Figura 7.3 - llustração em etapas do modelo de evolução sedimentar da planície do Ji. Cada quadro corresponde a um momento do desenvolvimento da planície (ordenados da esquerda para a direita e de cima para baixo). A data de início em 5000 anos AP é aproximada. 


\section{REFERÊNCIAS BIBLIOGRÁFICAS}

ABREU, S.F. 1928. Sambaquis de Imbituba e Laguna, Santa Catarina. Revista da Sociedade de Geografia. Separata.

ADAMIEC, G. \& AITKEN, M.J. 1998. Dose-rate conversion factors: update. Ancient TL 16, $37-$ 50.

AITCHISON, J. 1982. The statistical analysis of compositional data (with discussion). Journal of the Royal Statistical Society, Series B (Statistical Methodology) 44(2), 139-177.

AITKEN, M. J. 1985. Thermoluminescence Dating. Academic Press, London.

AITKEN, M.J. 1998. Optical Dating. Academic Press, London.

AMARAL, P.G. C. 2008. Evolução da sedimentação lagunar holocênica na região de Jaguaruna, Estado de Santa Catarina: uma abordagem sedimentológicamicropaleontológica integrada. 2008. Tese de Doutorado (inédito), Instituto de Geociências, Universidade de São Paulo, São Paulo. 165pp.

ANDERTON, R. 1985. Clastic facies models and facies analysis. In: BRENCHLEY, P. J. \& WILLIAMS, B. P. J. eds. Recent Developments and Applied Aspects. Oxford, The Geol. Soc. - Blackwell Scientific Publ. pp. 31-47.

ANGULO, R.J. 1992. Geologia da Planície Costeira do Estado do Paraná. Dissertação de Mestrado (inédito), Instituto de Geociências, Universidade de São Paulo, p. 334.

ANGULO, R.J. \& LESSA, G.C. 1997. The Brazilian sea level curves: a critical review with emphasis on the curves from Paranaguá and Cananéia regions. Marine Geology 140,141166.

ANGULO, R.J., SUGUIO, K. 1995. Re-evaluation of the Holocene sealevel maxima for the state of Paraná, Brazil. Paleogeol. Paleoclimol. Paleontol. 113, 385-393.

ANGULO, R.J.; GIANNINI, P.C.F.; KOGUT, J.S.; PRAZERES FILHO, H.J.; SOUZA, M.C. 1994. Variation of sedimentological parameters with deposition age across a succession of beach-ridges in the Holocene of Mel Island, Paraná, Brazil. In: International Sedimentological Congress 14. Recife, 1994. Abstracts... Recife, IAS, p.D1-D3

ANGULO, R.J.; GIANNINI, P.C.F.; KOGUT, J.S.; PRAZERES FILHO, H.J.; SOUZA, M.C. 1996. Variação das características sedimentológicas através de uma sucessão de cordões holocênicos, como função da idade deposicional, na ilha do Mel (PR). Bol. Paranaense de Geociências 44,77-86.

ANGULO, R.J.; GIANNINI, P.C.F.; SUGUIO, K.; PESSENDA, L.C.R. 1999. Relative sea level changes during the last 5500 years in the Laguna-Imbituba region (Santa Catarina, Brazil), based on vermetid radiocarbon ages. Marine Geology 159, 323-339.

ANGULO, R.J.; LESSA, G.C.; SOUZA, M.C. 2006. A Critical Review of Mid-to Late Holocene Sea-level Fluctuations on the Eastern Brazilian Coastline. Quaternary Science Reviews 25, 486-506.

ANGULO, R.J.; LESSA, G.C.; SOUZA, M.C. 2009. The Holocene Barrier Systems of Paranaguá and Northern Santa Catarina Coasts, Southern Brazil. In: S.R. Dillenburg \& P. Hesp (eds.) Geology of the Brazilian coastal barriers. Lect. Notes in Earth Sciences, 107, Springer-Verlag Berlin, p.:135-176

ARENS, S. M. 1996. Rates of aeolian transport on a beach in a temperate humid climate, Geomorphology 17, 3-18.

BAGNOLD, R.A. 1941. The Physics of Blown Sand and Desert Dunes. Methuen, London. 
BARBOUTI, A. \& B. RASTIN. 1983. A Study of the Absolute Intensity of Muons at Sea Level and under Various Thicknesses of Absorber. J. Pys. G: Nucl. Phys. 9, 15771595.

BEHLING, H. 1995. Investigations into the Late Pleistocene and Holocene history of vegetation and climate in Santa Catarina (Brazil). Vegetation History and Archaeobotany 4, 127-152.

BENTZ, D. 2004. Os Cordões Litorâneos da Planície de Una-Juréia, Municípios de Peruíbe e Iguape, SP. São Paulo, Instituto de Geociências da Universidade de São Paulo, Dissertação de Mestrado (inéd.). 108p, 4 anexos.

BIGARELLA, J.J. 1975. Lagoa dune field (State of Santa Catarina, Brazil) a model of eolian and pluvial activity. In: INTERNATIONAL SYMPOSIUM OF THE QUATERNARY, Curitiba Special Contributions...Bol. Paranaense Geoc. (33),133-167.

BLIVI, A., ANTHONY, E.J, OYÉD, L.M. 2002. Sand barrier development in the bight of Benin, West Africa. Ocean \& Coastal Management 45, 185-200.

BOND, G.C., SHOWERS, W., CHESEBY, M., LOTTI, R., ALMASI, P., de MENOCAL, P., PRIORE, P., CULLEN, H., HAJDAS, I., BONANI, G. 1997. A pervasive millennial-scale cycle in North Atlantic Holocene and Glacial climates. Science 278, 1257-1266.

BOND, G., KROMER, B., BEER, J., MUSCHELER, R., EVANS, M.N. 2001. Persistent solar influence on North Atlantic climate during the Holocene, Science, 294, 2130-2136.

BøTTER-JENSEN, L., McKEEVER, S.W.S., WINTLE, A.G. 2003. Optically Stimulated Luminescence Dosimetry. Elsevier, Amsterdam.

BRISTOW, C.S. \& PUCILLO, K. 2006. Quantifying rates of coastal progradation from sediment volume using GPR and OSL: the Holocene fill of Guichen Bay, south-east South Australia. Sedimentology 53, 769-788.

BROOKE, B.P., LEE, R., COX, M., OLLEY, J., PIESTCH, T. 2008a. Rates of shoreline progradation during the last 1700 years at Beachmere, southeastern Queensland, Australia, based on OSL dating of beach ridges. Journal of Coastal Research 24 (3), 640648.

BROOKE, B.P., RYAN, D., PIESTCH, T., OLLEY, J., DOUGLAS, G., PACKETT, R., RADKE, L., FLOOD, P. 2008b. Influence of climate fluctuations and changes in catchment land use on Late Holocene and modern beach-ridge sedimentation on a tropical macrotidal coast: Keppel Bay, Queensland, Australia. Marine Geology 251, 195-208.

BRUUN, P. 1962. Sea level rise as a cause of shore erosion. Am. Soc. Civil Engin. Proc., J. Waterways Harbors Div., 88:117-130

BRUUN, P. 1987. Discussion of "Sea Level Rise Effects on Shoreline Position". Journal of Waterway, Port Coastal and Ocean Engin. 113, 550

CHANG, H., SCRIMSHAW, M.D., LESTER, J.N. 2001. A revised grain-size trend analysis program to define net sediment transport pathways. Comp. and Geosc., 27: 109-114.

CHURCHMAN, C.W. 1963. An analysis of the concept of simulation. Symposium on simulation models. In: Hoggatt, A.C. \& BALDERSTON, F.E. Cincinatti, South Western Publishing Co..

CIPRIANI, L. \& STONE, G.W. 2001. Net longshore sediment transport and textural changes in beach sediments along the Southwest Alabama and Mississippi barrier islands, USA. Journal of Coastal Research 17 (2), 443-458.

CORRÊA, I.C.S. 1996. Les variations du niveau de la mer durant les derniers 17.500 ans PB: l'exemple de la plate-forme continentale du Rio Grande do Sul - Brésil. Marine Geology $130,163-178$. 
CRUZ, F.W., Jr., BURNS, S.J., KARMANN, I., SHARP, W.D., VUILLE, M., CARDOSO, A.O, FERRARI, J.A., DIAS, P.L.S., VIANA O. Jr. 2005. Insolationdriven changes in atmospheric circulation over the past 116,000 years in subtropical Brazil, Nature 434, 63-66.

CRUZ, F.W., Jr., BURNS, S.J., KARMANN, I., SHARP, W.D., VUILLE, M., FERRARI, J.A. 2006. A stalagmite record of changes in atmospheric circulation and soil processes in the Brazilian subtropics during the Late Pleistocene. Quaternary Science Reviews 25, 27492761.

CRUZ, F. W., Jr., BURNS, S.J., JERCINOVIC, M., KARMANN, I., SHARP, W.D., VUILLE, M. 2007. Evidence of rainfall variations in southern Brazil from trace element ratios $(\mathrm{Mg} / \mathrm{Ca}$ and $\mathrm{Sr} / \mathrm{Ca}$ ) in a late Pleistocene stalagmite, Geochim Cosmochim Acta 71, 2250- 2263.

DeBLASIS, P.A.D.; EGGERS, S.; LAHR, M.; FIGUTI, L.; AFONSO, M.C.; GASPAR, M.D. 1998. Padrões de assentamento e formação de sambaquis em Santa Catarina. Revista do Museu de Arqueologia e Etnologia 8, 319-321.

DeBLASIS, P.A.D., KNEIP, A., SCHEEL-YBERT R., GIANNINI, P.C.F., GASPAR, M.D. 2007. Sambaqui e paisagem: dinâmica natural e arqueologia regional no sul de Santa Catarina. Arqueologia Suramericana 3(1), 29-61.

DeLIMA, J.L.M.P., VAN DIJK, P.M. and SPAAN, W.P. 1992. Splash-saltation transport under wind-driven rain. Soil Technol. 5, 151-166.

DeMIO, E. \& GIANNINI, P.C.F. 1997. Variação de Minerais pesados transversal a planície litorânea de Peruíbe-Itanhaém, SP. In: Congresso da Associação Brasileira de Estudos do Quaternário, 1997, Curitiba. Resumos Expandidos. Curitiba. pp. 63-67.

DIAS, G.T.M. \& KJERFVE, B. 2009. Barrier and Beach Ridge Systems of the Rio de Janeiro Coast. In: S.R. Dillenburg \& P. Hesp (eds.) Geology of the Brazilian coastal barriers. Lect. Notes in Earth Sciences, 107, Springer-Verlag Berlin, p.:225-252.

DILLENBURG, S.R., $\quad$ BARBOZA, E.G., $\quad$ TOMAZELLI, L.J., $\quad$ AYUP-ZOUAIN, R.N., HESP, P.A., CLEROT, L.C.P. 2009. The Holocene Coastal Barriers of Rio Grande do Sul. In: S.R. DILLENBURG \& P. HESP (eds). Geology of the Brazilian coastal barriers. Lect. Notes in Earth Sciences, 107, Springer-Verlag Berlin, p.: 53-91.

DOMINGUEZ, J.M.L., BITTENCOURT, A.C.S.P., MARTIN, L. 1983. O papel da deriva litorânea de sedimentos arenosos na construção das planícies costeiras associadas as desembocaduras dos rios São Francisco, Jequitinhonha, Doce e Paraíba do Sul. Rev. Brasil. Geocienc. 13, 98-105.

DOOB, J.L. 1990. Stochastic Processes. New York. John Wiley \& Sons. 654pp.

DULLER, G.A.T. 1995. Luminescence measurements using single aliquots: methods and applications. Radiation Measurements 24, 217-226.

EVANS O.F. 1939. Sorting and transportation of material in swash and backwash. J. Sediment. Petrol. 9(1), 28-31.

FISHER, W.L. \& McGOWEN, J.H. 1967. Depositional systems in Wilcox Group (Eocene) of Texas and their relation to occurrence of oil and gas. Bull. Am. Assoc. Petrol. Geologists 53(1), 30-54.

FITZGERAL, D.M., CLEARY, W.J., BUYNEVICH, I.V., HEIN, C.J., KLEIN, A.H.F., NILS, E.A., ANGULO, R.J. 2007. Strand plain evolution along the southern coast of Santa Catarina, Brazil. J Coastal Res. SI50, 1-15

FLEXOR, J-M., MARTIN, L., SUGUIO, K., DOMINGUEZ, J.M.L. 1984. Gênese dos cordões litorâneos da parte central da costa brasileira. Pp. 35-46 In: L. D. LACERDA, D. S. D. ARAÚJO, R. CERQUEIRA, B. TURCQ (Eds.) Restingas: Origem, Estrutura e Processos. CEUFF, Niterói. 
FOLK, R.L. 1951. Stages of textural maturity in sedimentary rocks. J. Sedim. Petrol. 21, 127-130.

FORNARI, M., GIANNINI, P.C.F., AMARAL, P.G.C., NASCIMENTO JR., D.R., MENEZES, P.M.L., SAWAKUCHI, A.O., ANGULO, R.J., PESSENDA, L.C.R. 1002. Composição isotópica ( $\delta 180$ e $\delta 13 \mathrm{C}$ ) e idades $14 \mathrm{C}$ de carapaças de Anomalocardia brasiliana e Petaloconchus varians no Holoceno da costa de Santa Catarina, Sul do Brasil. In: Anais do Congresso de Geoquímica dos Países de Língua Portuguesa, 9. Cabo Verde. Universidade de Cabo Verde.

GALEHOUSE, J.S. 1971. Point-counting. In: Carver, R.E. (Ed.), Procedures in Sedimentary Petrology. Wiley- Interscience, New York, pp. 385-407.

GALLOWAY, W.E. 1979. Introduction: The concept of natural systems. In: GALLOWAY, W.E.; KREITLER, C.W.; McGOWEN, J.H. eds. Depositional and Ground Water Flow Systems in the Exploration for Uranium. Austin, Bureau of Econ.Geol.,The Univ. of Texas, p.1-2.

GAO, S. \& COLLINS, M. 1991. A critique of the "McLaren Method" for defining sediment transport paths - discussion. J. Sediment. Petrol. 61(1),143-146.

GAO, S. \& COLLINS, M. 1992. Net sediment transport patterns inferred from grain size trends, based upon definition of "transport vectors". Sediment. Geol. 81 (1/2), 47-60.

GIANNINI, P.C.F. 1987. Sedimentação quaternária na planície costeira de Peruíbe-Itanhaém (SP). Dissertação de Mestrado, Instituto de Geociências, Universidade de São Paulo, 2v., 234p., 3 mapas.

GIANNINI, P.C.F. 1989. Evolução quaternária na planície costeira de Peruíbe Itanhaém ( SP) segundo resultados granulométricos um confronto de métodos de tratamento estatístico. Boletim Paranaense de Geociências, Curitiba, PR, v. 38, p. 1-50.

GIANNINI, P.C.F. 1993. Sistemas deposicionais no Quaternário costeiro entre Jaguaruna e Imbituba, SC. São Paulo, Inst. Geoc. Univ. S. Paulo. Tese de Doutoramento (inéd.). 2 v., 2 mapas, $439 \mathrm{p}$.

GIANNINI, P.C.F. 1998. Associações de fácies eólicas ativas na costa centro-sul de Santa Catarina. Anais da Acad. Bras. Ciências 3, 696

GIANNINI, P.C.F. 2002. Complexo lagunar centro-sul catarinense, valioso patrimônio sedimentológico, arqueológico e histórico. In: Sítios Geológicos e Paleontológicos do Brasil 75, 213-222. Edição eletrônica em www.unb/br/ig/sigep

GIANNINI, P.C.F. 2007. Sistemas Deposicionais Eólicos no Quaternário Costeiro do Brasil. São Paulo, Inst. Geoc. Univ. S. Paulo. Tese de Livre-Docência (inéd.). 205 p.

GIANNINI, P.C.F. \& SANTOS, E.R. 1994. Padrões de variação espacial e temporal na morfologia de dunas de orla costeira no centro-sul catarinense. Bol. Paranaense de Geociências 42, 73-96.

GIANNINI, P.C.F. \& SUGUIO, K. 1994. Diferenciação entre gerações de depósitos eólicos quaternários na costa Centro-sul de Santa Catarina. In: CONGR. BRASIL. DE GEOLOGIA, 38, Balneário Camboriú, SC. Resumos Expandidos. Balneário Camboriú, SBG. pp.402-403.

GIANNINI, P.C.F.; SUGUIO, K.; SANTOS-GIANNINI, E.R.; KOGUT, J.S. 1997a. Gerações de areias eólicas na escarpa de Guaiúba, Imbituba, SC. In: CONGR. ASSOC. BRASIL. DE ESTUDOS DO QUATERNÁRIO, 6, Curitiba. Resumos Expandidos. Curitiba, Abequa. pp.63-67. 9

GIANNINI, P.C.F.; LESSA, G.C.; KOGUT, J.S.; ANGULO, R.J. 1997b. Variação nas assembléias de minerais pesados de testemunhos rasos na planície costeira de Paranaguá (PR). In: CONGR. ASSOC. BRASIL. DE ESTUDOS DO QUATERNÁRIO, 6, Curitiba, PR. Resumos Expandidos. Curitiba, ABEQUA. pp.58-62. 
GIANNINI, P.C.F.; SAWAKUCHI, A.O.; MARTINHO C. T. 2001 A estratigrafia de seqüências na evolução das dunas costeiras de Santa Catarina, Sul do Brasil. In: CONGRESSO DO QUATERNÁRIO DOS PAÍSES DE LÍNGUA IBÉRICA, Lisboa, Portugal. Actas...p. 117120.

GIANNINI, P.C.F.; GUEDES, C.C.F.; ASSINE, M.L.; ANGULO, R.J.; SOUZA M.C.; PESSENDA, L.C.R.; TATUMI, S.H. 2003. Variação transversal e longitudinal de propriedades sedimentológicas nos cordões litorâneos da ilha Comprida, litoral sul paulista. In: CONGR. ASSOC. BRASIL. DE ESTUDOS DO QUATERNÁRIO, 9, Recife, PE. Recife, ABEQUA, Anais. (cd).

GIANNINI, P.C.F.; ANGULO, R.J.; SOUZA, M.C.; KOGUT, J.S.; DELAI, M.S. 2004. A erosão na costa leste da ilha do Mel, baía de Paranaguá, Estado do Paraná: modelo baseado na distribuição espacial de formas deposicionais e propriedades sedimentológicas. São Paulo, Revista Brasileira de Geociências 34(2), 231-242.

GIANNINI, P.C.F.; DEBLASIS, P.; SAWAKUCHI, A.O.; AMARAL, P.G.C. 2005. Processos e materiais geológicos e a construção de sambaquis no litoral sul de Santa Catarina. $X$ Congresso da ABEQUA, Guarapari - ES. Boletim de resumos (p. 196) e resumos expandidos (cd-rom).

GIANNINI, P.C.F.; SAWAKUCHI, A.O.; MARTINHO, C.T.; TATUMI, S.H. 2007. Eolian depositional episodes controlled by Late Quaternary relative sea level changes on the Laguna-Imbituba coast, South Brazil. Amsterdam, Marine Geology 237, 143-168.

GIANNINI, P.C.F., GUEDES, C.C.F., NASCIMENTO Jr., D.R., TANAKA, A.P.B., ANGULO, R.J., ASSINE, M.L., SOUZA, M.C. 2009. Sedimentology and morphologic evolution of the Ilha Comprida Barrier System, southern São Paulo coast. In: S.R. Dillenburg \& P. Hesp (eds.) Geology of the Brazilian coastal barriers. Lect. Notes in Earth Sciences, 107, Springer-Verlag Berlin, p.:177-224

GIANNINI, P.C.F.; VILLAGRAN, X.S.; FORNARI, M.; NASCIMENTO Jr., D.R., MENEZES, P.M.L.; TANAKA, A.P.B.; ASSUNÇÃO, D.C., DE BLASIS, P., AMARAL, P.G. 2010. Interações entre evolução sedimentar e ocupação humana na costa centro-sul de Santa Catarina, Brasil. Bol.Mus.Para.Emílio Goeldi.Cienc.Hum. 5(1), 105-128

GILLESPIE, D.T. 1992. Markov Processes: An Introduction for Physical Scientists. Academic Press, San Diego, 565pp.

GOODWIN, I.D., STABLES, M.A., OLLEY, J.M. 2006. Wave climate, sand budget and shoreline alignment evolution of the lluka-Woody Bay sand barrier, northern New South Wales, Australia, since 3000 yr BP. Marine Geology 226, 127-144.

GUEDES, C.C. 2003. Os Cordões Litorâneos e as Dunas Eólicas da Ilha Comprida, Estado de São Paulo. São Paulo. Trabalho de Formatura (inédito), Instituto de Geociências, Universidade de São Paulo, São Paulo. 53pp.

GUEDES, C.C. 2009. Evolução Sedimentar Quaternária da Ilha Comprida, Estado de São Paulo. Dissertação de Mestrado (inédito), Instituto de Geociências, Universidade de São Paulo, São Paulo.

GUEDES, C. C. F., GIANNINI, P.C.F., NASCIMENTO Jr., D.R., TANAKA, A.P.B. ; ROSSI, M.G. 2009. Fatores controladores da distribuição da assembléia de minerais pesados na Ilha Comprida, Sudeste do Brasil. In: Abstracts of the XII Congresso da ABEQUA, La Plata.

GUERRA, A.T. 1950. Contribuição ao estudo da geomorfologia e do Quaternário do litoral de Laguna (Santa Catarina). Rev. Bras. Geog. 12(4), 535-564.

GUPTA, A. K., ANDERSON, D. M., OVERPECK, J. T. 2003. Abrupt changes in the Asian southwest monsoon during the Holocene and their links to the North Atlantic Ocean, Nature 421, 354-357. 
HAUG, G.H., HUGHEN, K.A., SIGMAN, D.M., PETERSON, L.C., RFHL, U. 2001. Southward migration of the Intertropical Convergence Zone through the Holocene. Science 293, 1304-1308.

HESP, P.A. 1984. The formation of sand 'beach-ridges' and foredunes. Search 15, 289-291.

HESP, P.A. 1999. The beach backshore and beyond. In: SHORT, A.D. (Ed), Handbook of beach and shoreface morphodynamics, Chichester. J. Wiley \& Sons, NY, p.145-170.

HESP, P.A, DILLENBURG, S.R., BARBOSA, E.G., TOMAZELLI, L.J., AYUP-ZOUAIN, R.N., ESTEVES, L.S., GRUBER, N.L.S., TOLDO, E.E., TABAJARA, L.L.C. De A. TABAJARA, CLEROT, L.C.P. 2005. Beach ridges, foredunes and an examination of the Torres to Tramandaí barrier system, southern Brazil. Anais da Academia Brasileira de Ciências 77(3), 493-508.

HESP, P.A., GIANNINI, P.C.F., MARTINHO, C.T., MYOT da SILVA, G., ASP, N.E. 2009. The Holocene barrier systems of the central and southern Santa Catarina coast, southern Brazil. In: Dillenburg, S.R. \& Hesp, P.A. Geology and Geomorphology of Holocene Coastal Barriers of Brazil. Springer-Verlag. pp. 93-133.

HOWARD, R. A. 1971. Dynamic Probabilistic Systems Volume I: Markov Models. New York: Wiley.

HSU, K.J. 1983. Actualistic catastrophism. Sedimentology 30(1), 3-9.

HUBERT, J.E. 1962. A zircon-tourmaline-rutile maturity index and the interdependence of the composition of heavy mineral assemblages with the cross composition and texture of sandstones. J. Sed. Pet.32, 440-450.

HUNTER, R.E. \& RICHMOND, B.M. 1988. Daily cycles in coastal dunes: Sedimentary Geology 55, 43-67.

ISLA, F.I. 1989. Holocene sea-level fluctuation in the Southern Hemisphere. Quatern. Sci. Rev. 8(4), 359-368.

ISLA, F.I., BUJALESKY, G.G. 2000. Cannibalisation of Holocene gravel beach-ridge plains, northern Tierra del Fuego, Argentina. Marine Geology, 170: 105-122.

ISLA, F.I., CORTIZO, L.C., TURNO ORELLANO, H.A. 2001. Dinámica y evolución de las barreras medanosas, provincia de buenos aires, Argentina. Rev. Bras. Geom. 2, 73-83.

IVANOV, S. 1996. Variability of sedimentary sequences: numerical modeling of the deposition-erosion process. Geol. Rundsch 85:12-18.

KOUSKY, V. E. 1979. Frontal influences on northeast Brazil. Monthly Weather Review. 107, $1140-1153$.

KOWSMANN, R.O., COSTA, M.P.A. 1979. Sedimentação quaternária da margem continental brasileira e das áreas oceânicas adjacentes. Technical Report, v.8, REMAC Project (Reconhecimento Global da Margem Continental Brasileira). PETROBRAS-DNPM-CPRMDHN-CNPq, Brazil.

LANDIM, P. M. B. 1998. Análise estatística de dados geológicos. São Paulo, Editora da UNESP, 226p.

LESSA, G.C., ANGULO, R.J., GIANNINI, P.C., ARAÚJO, A.D. 2000. Stratigraphy and Holocene evolution of a regressive barrier in south Brazil. Marine Geology 187, 87-108.

LIAN, O.B. \& ROBERTS, R.G. 2006. Dating the Quaternary: progress in luminescence dating of sediments. Quaternary Science Reviews 25, 2449-2468.

LOPEZ, G.I., RINK, W.J. 2007. Characteristics of the burial environment related to quartz SAR-OSL dating at St. Vincent Island, NW Florida, USA. Quaternary Geochronology 2, 65-70. 
LUTZ, M. \& ASCHER, D. 2007. Aprendendo Python. Bookman. 566pp.

MADSEN, A.T., MURRAY, A.S. 2009. Optically stimulated luminescence dating of young sediments: A review. Geomorphology 109, p. 3-16

MADSEN, A.T., MURRAY, A.S., ANDERSEN, T.J., PEJRUP, M., BREUNING-MADSEN, H. 2005. Optically stimulated luminescence dating of young estuarine sediments: a comparison with ${ }^{210} \mathrm{~Pb}$ and ${ }^{137} \mathrm{Cs}$ dating. Marine Geology 214, 251-268.

MANGE, M.A., MAURER, H.F.W. 1992. Heavy Minerals in Colours. Chapman \& Hall, London.

MANLY, B.F.J. 1994. Multivariate Statistical Methods - A primer. Chapman \& Hall, London, 215pp.

MARTIN, L. \& SUGUIO, K. 1986. Excursion route along the coastal plains of the States of Paraná and Santa Catarina. In: INTERNATIONAL SYMPOSIUM ON SEA-LEVEL CHANGES AND QUATERNARY SHORELINES, São Paulo. Special Publication (1)...São Paulo, IGUSP-FAPESP, $124 \mathrm{p}$.

MARTIN, L., SUGUIO, K., FLEXOR, J.N., AZEVEDO, A.E.G. 1988. Mapa Geológico do Quaternário costeiro dos estados do Paraná e Santa Catarina. Brasília, DNPM, 40 p., 2 mapas (Série Geologia 28, Seção Geologia Básica 18).

MARTINHO, C.T. 2004. Morfodinâmica e Sedimentologia de Campos de Dunas Transgressivos da Região de Jaguaruna-Imbituba, Santa Catarina. (inédito) Dissertação de Mestrado, Instituto de Geociências, Universidade de São Paulo, São Paulo, 108 pp.

MARTINHO, C.T. \& GIANNINI, P.C.F. 2001. Petrografia e microscopia eletrônica de varredura de diferentes gerações de paleodunas eólicas quaternárias do morro de Santa Marta, município de Laguna, SC. Porto Alegre, Revista Pesquisas em Geociências 28(2), 53-66.

MARTINHO, C.T., DILLENBURG, S.R., HESP, P.A. 2008. Mid to late Holocene evolution of transgressive dunefields from Rio Grande do Sul coast, southern Brazil. Marine Geology 256, 49-64.

McLAREN, P. 1981. An interpretation of trends in grain size measures. Journal of Sedimentary Petrology 51(2), 611-624.

McLAREN, P. \& BOWLES, D. 1985. The effects of sediment transport on grain-size distributions. J.Sediment. Petrol. 55(4), 457-470.

MENDES, V.R. 2009. Sedimentologia e morfoecologia ao longo do sistema praia-duna de Peruíbe, SP: Uma avaliação da influência da ocupação antrópica recente.

MENEZES, P.M. L. 2009. Análise de fácies e proveniência sedimentar em sambaquis do litoral centro-sul de Santa Catarina. (inédito) Dissertação de Mestrado, Instituto de Geociências, Universidade de São Paulo, São Paulo, 175pp.

MILNE, G.A., LONG, A.J., BASSETT, E. 2005. Modeling Holocene relative sea-level observations from the Caribbean and South America. Quaternary Science Reviews 24, 1183-1202.

MITROVICA, J.X., MILNE, G.A. 2002. On the origin of late Holocene sea level highstands within equatorial basins. Quat. Sci. Rev. 21, 2179- 2190.

MONTEIRO, C.A.F. 1958. Atlas geográfico de Santa Catarina. IBGE - Departamento Estadual de Geografia e Cartografia (Série 2, pub.2), Florianópolis.

MORTON, A.C., HALLSWORTH, C.R. 1994. Identifying provenance-specific features of detrital heavy mineral assemblages in sandstones. Sedimentary Geology 90(3-4), 241256.

MORTON, A.C.; HALLSWORTH, C.R. 1999. Processes controlling the composition of heavy mineral assemblages in sandstones. Sedimentary Geology 124(1-4), 3-29. 
MOY, C.M., DUNBAR, R.B., MORENO, P.I., FRANCOIS, J-P, VILLA-MARTINEZ, R., MUCCIARONE, D.M., GUILDERSON, T.P., GARREAUD, R.D. 2008. Isotopic evidence for hydrologic change related to the westerlies in SW Patagonia, Chile, during the last millenium. Quaternary Science Reviews 27, 1335-1349.

MURRAY, A.S. \& WINTLES, A.G. 2000. Luminescence dating of quartz using an improved single-aliquot regenerative-dose protocol. Radiation Measurement 32, 57-73.

MURRAY-WALLACE, C.V., Banerjee, R.P., Bourman, J.M., Olley, J.M. \& Brooke, B.P. 2002. Optically stimulated luminescence dating of Holocene relict foredunes, Guichen Bay, South Australia. Quaternary Science Reviews 21, 1077-1086.

NASCIMENTO Jr., D.R., TANAKA, A.P.B., GIANNINI, P.C.F., GUEDES, C.C.F. 2005. Morfologia e Granulometria ao longo do Sistema Praia-Duna Frontal da Ilha Comprida, SP. In: Congresso Da Associação Brasileira De Estudos Quaternários, Guarapari, ES. Anais (inéd.).

NIELSEN, A., MURRAY, A.S., PEJRUP, M., ELBERLING, B. 2006. Optically stimulated luminescence dating of a Holocene beach ridge plain in Northern Jutland, Denmark. Quaternary Geochronology, 1, 305-312.

NIMER, E. 1966. Circulação atmosférica do Brasil. Rev. Bras. Geogr 28 (3), 232-250.

NIMER, E. 1979. Climatologia do Brasil. Rio de Janeiro, IBGE. 2 ed., 421 pp.

O'BRIEN, S.R., MAYEWSKI, P.A., MEEKER, L.D., MEESE, D.A., TWICKER, M.S., WHITLOW, S.I. 1995. Complexity of Holocene climate as reconstructed from a Greenland ice core. Science 270, 1962-1964.

OTVOS, E.G. 2000. Beach ridges - definitions and significance. Geomorphology 32, 83-108.

PETTIJOHN, F.J. 1941. Persistence of heavy minerals and geologic age. J.Geol. 49(2), 612625.

PETTIJOHN, F.J. 1957. Sedimentary Rocks. 2nd edition, Harper \& Row, New York.

PIMIENTA, J. 1958. A faixa costeira meridional de Santa Catarina. Rio de Janeiro, DNPM/DGM. 104p. (Boletim 176).

PLUNKETT, G. \& SWINDLES, G.T. 2008. Determining the Sun's influence on Lateglacial and Holocene climates: a focus on climate response to centennial-scale solar forcing at 2800 cal. BP. Quaternary Science Reviews 27, 175-184.

PRESCOTT, J. R. \& STEPHAN, L.G. 1982. The Contribution of Cosmic Radiation to the Environmental Dose for Thermoluminescence Dating. PACT 6, 17-25.

RODRIGUES, M.L.G., FRANCO, D., SUGAHARA, S., 2004. Climatologia de frentes frias no litoral de Santa Catarina. Revista Brasileira de Geofísica 22 (2), 135-151.

ROSEMBLUETH, A \& WIENER, N. 1945. The role of models in science. Philosophy of Science XII(4), 316-321

ROSS, S. M. 1990. A Course in Simulation. Collier Macmillan, London, U.K.

ROY, P.S., COWELL, M.A., FERLAND, M.A., THOM, B.G. 1994. Wave-dominated coasts. In: Carter, R.W.G.,Woodroffe, C.D. (Eds.), Coastal Evolution - Late Quaternary Shoreline Morphodynamics. Cambridge University Press, Cambridge, 121-186.

RUBEY, W.W. 1933. The size-distribution of heavy minerals within a water-laid sandstone. Journal of Sedimentary Petrology 3, 3-29.

SADLER, P.M. 1981. Sediment accumulation rates and the completeness of stratigraphic sections. Journal of Geology 89, 569-584.

SARRE, R.D. 1989. Aeolian sand drift from the intertidal zone on a temperate beach: potential and actual rates. Earth Surf. Proc. Landf. 14, 247-258. 
SATYAMURTI, P., Nobre, C., Dias, P.L.S. 1998. South America. In: Karoly, D.J., Vicent, D.J. (Eds.), Meteorology of the Southern Hemisphere. American Meteorological Society, Boston, pp. 119-139.

SAWAKUCHI, A.O. 2003. Sistemas Deposicionais Eólicos na Costa Centro-Sul Catarinense: Relações com o Nível do Mar. São Paulo, Inst. Geoc. Univ. S. Paulo. Dissertação de Mestrado (inéd.), v. 1, 86 p.

SAWAKUCHI, A.O. 2006. Morfometria e Simulação Numérica de Campos de Dunas Costeiros: Estudo Baseado em Exemplos Brasileiros. São Paulo, Inst. Geoc. Univ. S. Paulo. Tese de Doutoramento (inéd.), 316pp.

SAWAKUCHI, A.O., KALCHGRUBER, R., GIANNINI, P.C.F., NASCIMENTO Jr., D.R., GUEDES, C.C.F., UMISEDO, N.K. 2008. The development of blowouts and foredunes in the Ilha Comprida barrier (Southeastern Brazil): the influence of Late Holocene climate changes on coastal sedimentation. Quaternary Science Reviews 27, 2076-2090.

SAWAKUCHI, A.O., GIANNINI, P.C.F., MARTINHO, C.T., TANAKA, A.P.B. 2009. Grain size and heavy minerals of the Late Quaternary eolian sediments from the ImbitubaJaguaruna coast, Southern Brazil: Depositional controls linked to relative sea-level changes. Sedimentary Geology 222, 226-240.

SOUZA, L.A.P.; SILVA, R.F.; IYOMASA, W.S. 1998. Métodos de investigação. In: Oliveira, A.M.S. \& Brito, S.N.A. (eds.) 1998. Geologia de Engenharia. São Paulo: Assoc. Bras. De Geologia de Engenharia, $586 \mathrm{p}$.

STERMAN, J.D. 2000. Business Dynamics: Systems Thinking and Modeling for a Complex World, Boston: McGraw-Hill. 982pp.

STRANHLER, A.N. 1977. Physical geography. Barcelona, Omega.

SUGUIO, K., MARTIN, L., BITTENCOURT, A.C.S.P., DOMINGUEZ, J.M.L., FLEXOR, J.M., de AZEVEDO, A.E.G. 1985. Flutuações do nível relativo do mar durante o Quaternário superior ao longo do litoral brasileiro e suas implicações na sedimentação costeira. Revista Brasileira de Geociências 15, 273-286.

SUGUIO, K., MARTIN, L., FLEXOR, J.M. 1988. Quatemary sealevels of the Brazilian coast: recent progress. Episodes 11 (3), 2033208.

TANAKA, A.P.B. 2007. Evolução Sedimentar da Planície Retrobarreira de Campos Verdes (Laguna, SC) e os Sambaquis de Carniça. São Paulo, Inst. Geoc. Univ. S. Paulo. Trabalho de Formatura (inéd.). 84p.

TANAKA, A.P.B., GIANNINI, P.C.F., SAWAKUCHI, A.O. 2008. Rumo de crescimento progradacional da planície de cordões litorâneos de Campos Verdes (Laguna, SC). In: Abstracts of the $44^{\circ}$ Congresso Brasileiro de Geologia, Curitiba.

TANAKA, A.P.B., GIANNINI, P.C.F., FORNARI, M., NASCIMENTO, D.R., Jr., SAWAKUCHI, A.O., RODRIGUES, S.I., MENEZES, P.M.L., DeBLASIS, P., PORSANI, J.L. 2009a. A planície costeira holocênica de Campos Verdes (Laguna, SC): evolução sedimentar inferida a partir de georradar (GPR), granulometria e minerais pesados. Rev. Bras. Geoc 39(4), 750-766.

TANAKA, A.P.B., GIANNINI, P.C.F., SAWAKUCHI, A.O. 2009b. Variação das propriedades sedimentológicas em uma sucessão de cordões litorâneos da planície do Ji (Laguna, Santa Catarina, Brasil). In: Abstracts of the XII Congresso da ABEQUA, La Plata.

TESSLER, M.G. 1982. Sedimentação Atual na Região Lagunar de Cananéia - Iguape, Estado de São Paulo. Inst. de Geoc. Univ. S. Paulo. Dissertação de Mestrado 2v., 8 mapas, 110p. 
TESSLER, M.G. 1988. Dinâmica Sedimentar Quaternária no Litoral Sul Paulista. São Paulo, Inst. Geoc. Univ. S. Paulo. Tese de Doutorado (inéd.), 1 mapa, 276p.

THOMPSON, L.G., MOSLEY-THOMPSON, E., DANSGAARD, W., GROOTES, P.M. 1986. The Little Ice Age as recorded in the stratigraphy of the tropical Quelccaya ice cap. Science 234, 361-364.

TOMAZELLI, LJ. 1990. Contribuição ao estudo dos sistemas deposicionais holocênicos do nordeste da província costeira do Rio Grande do Sul, com ênfase no sistema eólico. Tese de Doutorado, Instituto de Geociências, UFRGS, Porto Alegre.

TOMAZELLI, L.J. \& VILLWOCK, J.A. 2005. Mapeamento geológico de planícies costeiras: o exemplo da costa do Rio Grande do Sul. Gravel, 3:109-115

VAN ANDEL, T.H., LABOREL, J. 1964. Recent high relative sea level stand near Recife, Brazil. Science 145, 580-581.

VAN GEEL, B., BUURMAN, J., WATERBOLK, H.T. 1996. Archaeological and palaeoecological indications of an abrupt climate change in The Netherlands, and evidence for climatological teleconnections around 2650 BP. Journal of Quaternary Science 11, 451-460.

VAN GEEL, B., HEUSSER, C.J., RENSSEN, H., SCHUURMANS, C.J.E. 2000. Climatic change in Chile at around $2700 \mathrm{BP}$ and global evidence for solar forcing: a hypothesis. The Holocene 10, 659-664.

WALLACE, J.M. \& HOBBS, P.V. 1977. Atmospheric Science: An Introductory Survey. Academic Press, Inc, London, pp.467.

WANNER, H., BEER, J., BÜTIKOFER, J., CROWLEY, C., CUBASCH, U., FLÜCKIGER, J., GOOSSE, H., GROSJEAN, M., JOOS, F., KAPLAN, J.O., KÜTTEL, M., MÜLLER, S.A., PRENTICE, C., SOLOMINA, O., STOCKER, T.F., TARASOV, P., WAGNER, M., WIDMANN, M. 2008. Mid- to Late Holocene climate change: an overview. Quat. Sci. Rev. 27, 1781-1828.

WANG, Y.J., CHENG, H., EDWARDS, R.L., HE, Y.Q., KONG, X.G., AN, Z.S., WU, J.Y., KELLY, M.J., DYKOSKI, C.A., LI, X.D. 2005. The Holocene Asian monsoon: links to solar changes and North Atlantic climate. Science 308: 854-857.

WANG, X., AULER, A.S., EDWARDS, R.L., CHENG, H., ITO, E., SOLHEID, M. 2006. Interhemispheric anti-phasing of rainfall during the last glacial period. Quaternary Science Reviews 25, 3391-3403.

WINTLE, A. G. 1997. Luminescence dating: Laboratory procedures and protocols. Radiat. Meas. 27, 769-817.

WINTLE, A.G. \& MURRAY, A.S. 2006. A review of quartz optically stimulated luminescence characteristics and their relevance in single-aliquot regeneration dating protocols. Radiation Measurements 41, 369-391.

WOODROFFE, C.D., CURTIS, R.J., McLEAN, R.F. 1983. Development of a Chenier Plain, Firth of Thames, New Zealand. Marine Geology 53, 1-22.

ZENKOVITCH, V.P. 1971. Processes of Coastal Development. Edinburgh-London, Oliver \& Boyd, 738 p. 


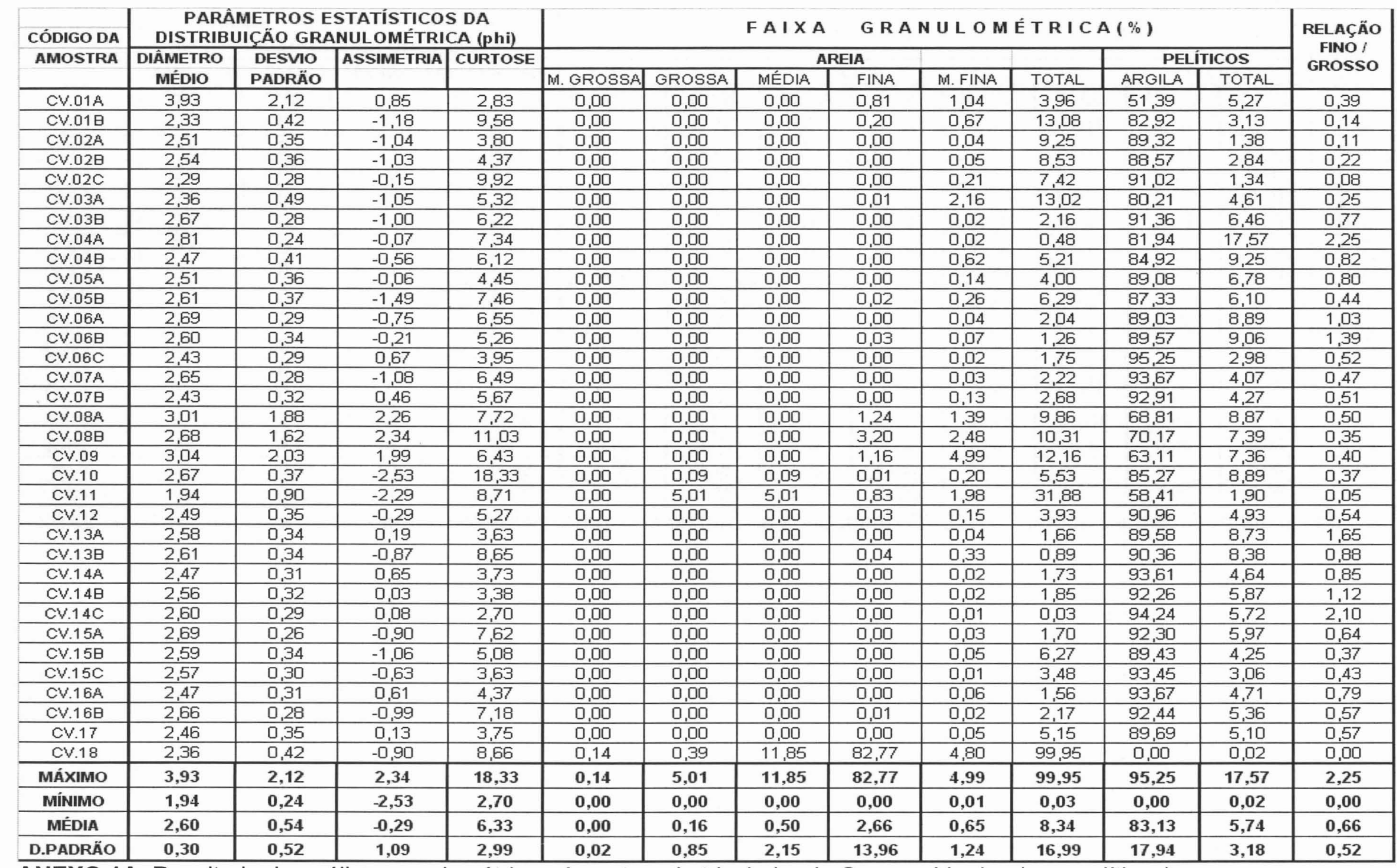

ANEXO 1A. Resultado da análise granulométrica - Amostras de trincheira de Campos Verdes (sem pelíticos). 


\begin{tabular}{|c|c|c|c|c|c|c|c|c|c|c|c|c|c|}
\hline \multirow{3}{*}{$\begin{array}{l}\text { INTERVALO } \\
\text { AMOSTRADO } \\
\text { (m) }\end{array}$} & \multicolumn{4}{|c|}{$\begin{array}{l}\text { PARÂMETROS ESTATÍSTICOS DA } \\
\text { DISTRIBUIÇÄO GRANULOMÉTRICA (phi) }\end{array}$} & \multicolumn{8}{|c|}{ FAIXA } & \multirow{3}{*}{$\begin{array}{l}\text { RELAÇÃO } \\
\text { FINO / } \\
\text { GROSSO }\end{array}$} \\
\hline & \multirow{2}{*}{\begin{tabular}{|c|} 
DIÂMETRO \\
MÉDIO \\
\end{tabular}} & \multirow{2}{*}{$\begin{array}{c}\text { DESVIO } \\
\text { PADRÃO } \\
\end{array}$} & \multirow[t]{2}{*}{ ASSIMETRIA } & \multirow[t]{2}{*}{ CURTOSE } & \multicolumn{4}{|c|}{ AREIA } & \multirow[b]{2}{*}{ M. FINA } & \multirow[b]{2}{*}{ TOTAL } & \multicolumn{2}{|c|}{ PELÍtICOS } & \\
\hline & & & & & M. GROSSA & GROSSA & MÉDIA & FINA & & & ARGILA & TOTAL & \\
\hline $1,5-2,5$ & 2,71 & 0,35 & $-1,16$ & 7,24 & 0,00 & 0,21 & 3,93 & 82,17 & 13,69 & 100,00 & 0,00 & 0,00 & 0,00 \\
\hline $2,5-3,5$ & 2,82 & 0,40 & $-1,80$ & 16,46 & 0,18 & 0,17 & 1,51 & 69,51 & 28,62 & 100,00 & 0,00 & 0,00 & 0,00 \\
\hline $3,5-4,5$ & 2,95 & 0,29 & $-0,23$ & 7,03 & 0,01 & 0,06 & 0,13 & 58,83 & 40,97 & 100,00 & 0,00 & 0,00 & 0,00 \\
\hline $4,5-5,5$ & 2,90 & 0,31 & $-0,30$ & 7,97 & 0,01 & 0,07 & 0,55 & 66,57 & 32,79 & 100,00 & 0,00 & 0,00 & 0,00 \\
\hline $6,5-7,5$ & 2,95 & 0,51 & $-4,05$ & 31,06 & 0,36 & 0,30 & 0,68 & 47,18 & 51,06 & 99,57 & 0,00 & 0,00 & 0,00 \\
\hline $7,5-8,5$ & 2,81 & 0,43 & $-1,23$ & 7,42 & 0,01 & 0,53 & 3,30 & 64,57 & 31,58 & 100,00 & 0,00 & 0,00 & 0,00 \\
\hline $8,5-9,5$ & 3,14 & 0,33 & $-1,75$ & 12,30 & 0,02 & 0,15 & 0,65 & 24,32 & 74,87 & 100,00 & 0,00 & 0,00 & 0,00 \\
\hline $9,5-10,5$ & 3,17 & 0,33 & $-3,32$ & 32,90 & 0,13 & 0,18 & 0,26 & 20,42 & 79,01 & 100,00 & 0,00 & 0,00 & 0,00 \\
\hline $10,5-11,5$ & 3,31 & 0,41 & $-0,80$ & 5,41 & 0,01 & 0,08 & 0,13 & 22,63 & 77,14 & 100,00 & 0,00 & 0,00 & 0,00 \\
\hline $11,5-12,5$ & 3,22 & 0,26 & $-1,12$ & 11,72 & 0,00 & 0,03 & 0,19 & 14,61 & 85,17 & 100,00 & 0,00 & 0,00 & 0,00 \\
\hline $12,5-13,5$ & 3,30 & 0,27 & $-0,30$ & 6,96 & 0,00 & 0,04 & 0,02 & 8,98 & 90,96 & 100,00 & 0,00 & 0,00 & 0,00 \\
\hline $13,5-14,5$ & 3,17 & 0,30 & $-2,59$ & 25,17 & 0,01 & 0,29 & 0,07 & 20,82 & 78,82 & 100,00 & 0,00 & 0,00 & 0,00 \\
\hline MÁXIMO & 3,31 & 0,51 & $-0,23$ & 32,90 & 0,36 & 0,53 & 3,93 & 82,17 & 90,96 & 100,00 & 0,00 & 0,00 & 0,00 \\
\hline MíNIMO & 2,71 & 0,26 & $-4,05$ & 5,41 & 0,00 & 0,03 & 0,02 & 8,98 & 13,69 & 99,57 & 0,00 & 0,00 & 0,00 \\
\hline MÉDIA & 3,04 & 0,35 & $-1,56$ & 14,30 & 0,06 & 0,18 & 0,95 & 41,72 & 57,06 & 99,96 & 0,00 & 0,00 & 0,00 \\
\hline D.PADRÃO & 0,20 & 0,07 & 1,17 & 9,50 & 0,11 & 0,14 & 1,26 & 24,55 & 25,56 & 0,12 & 0,00 & 0,00 & 0,00 \\
\hline
\end{tabular}

ANEXO 1B. Resultado da análise granulométrica - Amostras do furo de sondagem (CVS) de Campos Verdes (sem pelíticos). 


\begin{tabular}{|c|c|c|c|c|c|c|c|c|c|c|c|c|c|}
\hline \multirow{3}{*}{$\begin{array}{l}\text { CÓDIGO DA } \\
\text { AMOSTRA }\end{array}$} & \multicolumn{4}{|c|}{$\begin{array}{l}\text { PARÂMETROS ESTATÍSTICOS DA } \\
\text { DISTRIBUIÇÄO GRANULOMÉTRICA (phi) }\end{array}$} & \multicolumn{8}{|c|}{$F A \mid X A$} & \multirow{3}{*}{$\begin{array}{l}\text { RELAÇÄO } \\
\text { FINO / } \\
\text { GROSSO }\end{array}$} \\
\hline & \multirow{2}{*}{\begin{tabular}{|c|} 
DIÂMETRO \\
MÉDIO \\
\end{tabular}} & \multirow{2}{*}{$\begin{array}{c}\text { DESVIO } \\
\text { PADRÅO }\end{array}$} & \multirow[t]{2}{*}{ ASSIMETRIA } & \multirow[t]{2}{*}{ CURTOSE } & \multicolumn{4}{|c|}{ AREIA } & \multirow[b]{2}{*}{ M. FINA } & \multirow[b]{2}{*}{ TOTAL } & \multicolumn{2}{|c|}{ PELÍTICOS } & \\
\hline & & & & & M. GROSSA & GROSSA & MÉDIA & FINA & & & ARGILA & TOTAL & \\
\hline J.01 & 2,71 & 0,32 & $-2,08$ & 19,71 & 0,10 & 0,09 & 2,38 & 86,78 & 10,54 & 99,88 & 0,00 & 0,12 & 0,00 \\
\hline J.02 & 2,55 & 0,40 & $-0,30$ & 4,06 & 0,00 & 0,24 & 5,46 & 83,14 & 11,07 & 99,92 & 0,00 & 0,08 & 0,00 \\
\hline J.03 & 2,46 & 0,31 & 0,69 & 4,50 & 0,01 & 0,05 & 0,91 & 93,75 & 5,27 & 99,98 & 0,00 & 0,02 & 0,00 \\
\hline Jl.04 & 2,73 & 0,27 & $-0,44$ & 7,60 & 0,01 & 0,01 & 0,51 & 88,50 & 10,90 & 99,93 & 0,00 & 0,07 & 0,00 \\
\hline J.05 & 2,61 & 0,33 & 0,34 & 2,90 & 0,00 & 0,01 & 0,08 & 88,66 & 11,23 & 99,98 & 0,00 & 0,02 & 0,00 \\
\hline J.06 & 2,62 & 0,40 & $-0,19$ & 3,50 & 0,01 & 0,09 & 4,21 & 79,71 & 15,78 & 99,80 & 0,00 & 0,20 & 0,00 \\
\hline J.07 & 2,73 & 0,40 & $-0,92$ & 7,82 & 0,08 & 0,11 & 2,27 & 74,90 & 22,48 & 99,84 & 0,00 & 0,16 & 0,00 \\
\hline ل1.08 & 2,58 & 0,34 & 0,36 & 3,22 & 0,01 & 0,01 & 0,35 & 88,66 & 10,95 & 99,99 & 0,00 & 0,01 & 0,00 \\
\hline ل09 & 2,49 & 0,32 & 0,86 & 3,21 & 0,00 & 0,02 & 0,33 & 91,95 & 7,67 & 99,97 & 0,00 & 0,03 & 0,00 \\
\hline J.10 & 2,52 & 0,30 & 0,61 & 2,60 & 0,00 & 0,00 & 0,07 & 94,31 & 5,60 & 99,99 & 0,00 & 0,01 & 0,00 \\
\hline 11.11 & 2,59 & 0,32 & 0,23 & 3,33 & 0,01 & 0,03 & 0,12 & 90,80 & 9,02 & 99,97 & 0,00 & 0,03 & 0,00 \\
\hline J.12 & 2,61 & 0,33 & 0,21 & 2,98 & 0,00 & 0,04 & 0,34 & 88,33 & 11,28 & 99,98 & 0,00 & 0,02 & 0,00 \\
\hline ل13.13 & 2,77 & 0,21 & 0,19 & 8,68 & 0,00 & 0,01 & 0,06 & 89,21 & 10,68 & 99,96 & 0,00 & 0,04 & 0,00 \\
\hline MÁXIMO & 2,77 & 0,40 & 0,86 & 19,71 & 0,10 & 0,24 & 5,46 & 94,31 & 22,48 & 99,99 & 0,00 & 0,20 & 0,00 \\
\hline MÍNIMO & 2,46 & 0,21 & $-2,08$ & 2,60 & 0,00 & 0,00 & 0,06 & 74,90 & 5,27 & 99,80 & 0,00 & 0,01 & 0,00 \\
\hline MÉDIA & 2,61 & 0,33 & $-0,03$ & 5,70 & 0,02 & 0,06 & 1,31 & 87,59 & 10,96 & 99,94 & 0,00 & 0,06 & 0,00 \\
\hline D.PADRÅO & 0,09 & 0,05 & 0,76 & 4,51 & 0,03 & 0,06 & 1,70 & 5,28 & 4,23 & 0,06 & 0,00 & 0,06 & 0,00 \\
\hline
\end{tabular}

ANEXO 1C. Resultado da análise granulométrica - Amostras de trincheira do Ji (sem pelíticos). 


\begin{tabular}{|c|c|c|c|c|c|c|c|c|c|c|c|c|c|c|c|c|c|c|c|c|c|}
\hline \multirow[t]{2}{*}{$\begin{array}{c}\text { CÓDIGO } \\
\text { DA } \\
\text { AMOSTRA }\end{array}$} & \multirow{2}{*}{\begin{tabular}{|c|} 
MINERAIS \\
OPACOS \\
OPA
\end{tabular}} & \multicolumn{14}{|c|}{$\begin{array}{l}\text { GRUPO DOS MINERAIS TRANSPARENTES NÄO MICÁCEOS: } \\
\text { FREQÜÊNCIA DE CONTAGEM NO GRUPO (\%) }\end{array}$} & \multicolumn{3}{|c|}{$\begin{array}{c}\text { ÍNDICES (i) DE } \\
\text { MATURIDADE QUIMICA }\end{array}$} & \multicolumn{3}{|c|}{$\begin{array}{c}\text { ÍNDICES (i) DE CONTROLE } \\
\text { (Seleçăo Hidraúlica, } \\
\text { Mudança de Área Fonte e } \\
\text { Maturidade) }\end{array}$} \\
\hline & & ZIR & \begin{tabular}{|l|} 
TUR \\
\end{tabular} & RUT & EST & EPI & GRA & \begin{tabular}{|l|} 
SIL \\
\end{tabular} & \begin{tabular}{|l|}
$\mathrm{ClA}$ \\
\end{tabular} & AND & CPX & \begin{tabular}{|l|}
$\mathrm{HOR}$ \\
\end{tabular} & TREM & $\mathrm{ALT}$ & TOTAL & $\mathrm{i} Z \mathrm{TTR}$ & iMET & ilNS & $\mathrm{iTZ}$ & $\mathrm{iRZ}$ & $\mathrm{iHT}$ \\
\hline CV.01A & 53 & 16 & 30 & 3 & 19 & 10 & 1 & 1 & 4 & 0 & 0 & 13 & 0 & 3 & 100 & 50 & 36 & 14 & 91 & 10 & 10 \\
\hline CV.01B & 32 & 9 & 48 & 1 & 14 & 16 & 0 & 0 & 1 & 0 & 0 & 4 & 0 & 7 & 100 & 63 & 33 & 4 & - & - & - \\
\hline CV.02A & 22 & 12 & 44 & 3 & 9 & 13 & 2 & 2 & 7 & 0 & 0 & 4 & 0 & 6 & 100 & 62 & 34 & 4 & 82 & 13 & 35 \\
\hline CV.02B & 30 & 9 & 23 & 6 & 11 & 21 & 1 & 0 & 7 & 1 & 1 & 12 & 1 & 7 & 100 & 41 & 43 & 15 & 76 & 20 & 31 \\
\hline CV.02C & 34 & 9 & 35 & 3 & 13 & 15 & 1 & 1 & 5 & 0 & 1 & 12 & 0 & 5 & 100 & 48 & 38 & 13 & 88 & 29 & 24 \\
\hline CV.03A & 27 & 6 & 26 & 0 & 2 & 14 & 0 & 3 & 13 & 0 & 0 & 21 & 2 & 15 & 100 & 38 & 36 & 26 & 89 & 5 & 42 \\
\hline CV.03B & 16 & 6 & 28 & 2 & 3 & 17 & 0 & 0 & 8 & 0 & 0 & 19 & 0 & 18 & 100 & 43 & 34 & 23 & - & - & - \\
\hline CV.04A & 10 & 5 & 43 & 1 & 2 & 14 & 0 & 3 & 4 & 0 & 0 & 15 & 0 & 13 & 100 & 57 & 26 & 17 & - & - & - \\
\hline CV.04B & 13 & 8 & 37 & 3 & 7 & 12 & 0 & 3 & 7 & 0 & 0 & 15 & 0 & 7 & 100 & 52 & 32 & 16 & 87 & 22 & 33 \\
\hline CV.05A & 12 & 8 & 30 & 3 & 4 & 16 & 0 & 1 & 4 & 0 & 0 & 13 & 2 & 19 & 100 & 51 & 31 & 19 & 95 & 28 & 38 \\
\hline CV.05B & 17 & 7 & 36 & 2 & 5 & 10 & 0 & 0 & 7 & 0 & 0 & 22 & 3 & 9 & 100 & 49 & 24 & 27 & - & - & - \\
\hline CV.06A & 46 & 19 & 35 & 3 & 6 & 18 & 1 & 2 & 7 & 0 & 0 & 8 & 0 & 2 & 100 & 57 & 34 & 8 & 88 & 32 & 22 \\
\hline CV.06B & 32 & 10 & 43 & 4 & 9 & 12 & 0 & 3 & 5 & 0 & 0 & 10 & 0 & 4 & 100 & 59 & 31 & 10 & - & - & - \\
\hline CV.06C & 21 & 9 & 42 & 3 & 4 & 18 & 1 & 0 & 5 & 0 & 0 & 11 & 1 & 6 & 100 & 58 & 29 & 13 & - & - & - \\
\hline CV.07A & 51 & 24 & 26 & 6 & 11 & 15 & 0 & 1 & 9 & 0 & 0 & 6 & 0 & 3 & 100 & 57 & 37 & 6 & 54 & 21 & 50 \\
\hline CV.07B & 50 & 22 & 32 & 4 & 6 & 16 & 0 & 0 & 7 & 0 & 0 & 12 & 0 & 1 & 100 & 59 & 29 & 12 & - & - & - \\
\hline CV.08A & 34 & 22 & 34 & 3 & 5 & 14 & 1 & 2 & 5 & 0 & 0 & 11 & 0 & 3 & 99 & 61 & 27 & 12 & 64 & 11 & 21 \\
\hline CV.08B & 34 & 17 & 33 & 4 & 8 & 14 & 1 & 1 & 7 & 1 & 0 & 10 & 0 & 5 & 100 & 56 & 33 & 10 & 78 & 26 & 20 \\
\hline CV.09 & 35 & 22 & 35 & 4 & 4 & 13 & 0 & 2 & 5 & 1 & 0 & 7 & 0 & 6 & 100 & 66 & 27 & 8 & 73 & 22 & 18 \\
\hline CV.10 & 32 & 10 & 40 & 6 & 13 & 11 & 0 & 1 & 7 & 1 & 0 & 6 & 0 & 5 & 100 & 59 & 35 & 6 & 77 & 5 & 16 \\
\hline CV.11 & 38 & 7 & 64 & 6 & 11 & 3 & 0 & 1 & 6 & 0 & 1 & 1 & 0 & 1 & 100 & 78 & 20 & 2 & 89 & 12 & 12 \\
\hline CV.12 & 25 & 7 & 44 & 4 & 3 & 15 & 0 & 1 & 9 & 0 & 0 & 14 & 0 & 4 & 100 & 57 & 29 & 14 & 84 & 19 & 29 \\
\hline CV.13A & 28 & 15 & 28 & 9 & 3 & 13 & 1 & 1 & 10 & 0 & 0 & 20 & 0 & 1 & 100 & 52 & 27 & 20 & - & - & - \\
\hline CV.13B & 29 & 14 & 29 & 4 & 11 & 18 & 0 & 0 & 5 & 0 & 0 & 15 & 0 & 3 & 100 & 50 & 35 & 16 & 82 & 12 & 38 \\
\hline CV.14A & 38 & 39 & 22 & 6 & 4 & 8 & 1 & 0 & 5 & 0 & 0 & 13 & 0 & 3 & 100 & 69 & 18 & 13 & 47 & 10 & 15 \\
\hline CV.14B & 48 & 34 & 27 & 4 & 7 & 8 & 0 & 0 & 5 & 0 & 1 & 10 & 0 & 4 & 100 & 68 & 21 & 11 & 67 & 15 & 14 \\
\hline CV.14C & 39 & 33 & 22 & 1 & 7 & 14 & 0 & 1 & 4 & 0 & 0 & 14 & 0 & 2 & 99 & 58 & 26 & 16 & 56 & 9 & 19 \\
\hline CV.15A & 16 & 12 & 47 & 1 & 3 & 14 & 0 & 0 & 2 & 0 & 0 & 10 & 1 & 10 & 100 & 67 & 21 & 12 & 92 & 19 & 12 \\
\hline CV.15B & 35 & 19 & 33 & 6 & 6 & 10 & 0 & 1 & 3 & 0 & 0 & 7 & 0 & 15 & 100 & 68 & 23 & 9 & - & - & - \\
\hline CV.15C & 36 & 14 & 57 & 5 & 3 & 11 & 1 & 0 & 2 & 0 & 0 & 7 & 0 & 1 & 100 & 77 & 16 & 7 & 86 & 21 & 10 \\
\hline CV.16A & 41 & 34 & 37 & 4 & 6 & 8 & 0 & 0 & 4 & 0 & 0 & 5 & 0 & 2 & 100 & 76 & 18 & 5 & - & - & - \\
\hline CV.16B & 44 & 22 & 36 & 6 & 7 & 12 & 1 & 0 & 5 & 0 & 0 & 7 & 0 & 5 & 100 & 67 & 25 & 8 & 63 & 18 & 21 \\
\hline CV.17 & 35 & 22 & 36 & 6 & 8 & 6 & 0 & 0 & 6 & 0 & 0 & 12 & 1 & 5 & 100 & 66 & 20 & 14 & 76 & 23 & 29 \\
\hline CRN.02A & 34 & 19 & 39 & 5 & 7 & 12 & 0 & 1 & 3 & 0 & 0 & 6 & 0 & 5 & 99 & 66 & 26 & 8 & - & - & - \\
\hline CV.18 & 53 & 55 & 18 & 6 & 4 & 9 & 0 & 0 & 3 & 1 & 0 & 4 & 0 & 0 & 99 & 79 & 17 & 4 & 32 & 5 & 23 \\
\hline MÁXIMO & 53 & 55 & 64 & 9 & 19 & 21 & 2 & 3 & 13 & 1 & 1 & 22 & 3 & 19 & 100 & 79 & 43 & 27 & 95 & 32 & 50 \\
\hline MíNIMO & 10 & 5 & 18 & 0 & 2 & 3 & 0 & 0 & 1 & 0 & 0 & 1 & 0 & 0 & 99 & 38 & 16 & 2 & 32 & 5 & 10 \\
\hline MÉDIA & 33 & 17 & 35 & 4 & 7 & 13 & 0 & 1 & 5 & 0 & 0 & 11 & 0 & 6 & 100 & 60 & 28 & 12 & 75 & 17 & 24 \\
\hline D.PADRÃO & 12 & 11 & 10 & 2 & 4 & 4 & 0 & 1 & 2 & 0 & 0 & 5 & 1 & 5 & 0 & 10 & 7 & 6 & 16 & 8 & 11 \\
\hline
\end{tabular}

ANEXO 2A. Resultado da contagem de minerais pesados - Amostras de trincheira de Campos Verdes (sem pelíticos). 


\begin{tabular}{|c|c|c|c|c|c|c|c|c|c|c|c|c|c|c|c|c|c|c|c|c|c|c|c|}
\hline \multirow[t]{2}{*}{$\begin{array}{c}\text { INTERVALO } \\
\text { AMOSTRAD0 } \\
\text { (m) }\end{array}$} & \multirow{2}{*}{$\begin{array}{c}\text { MINERAIS } \\
\text { OPACOS } \\
\text { OPA } \\
\end{array}$} & \multicolumn{16}{|c|}{$\begin{array}{l}\text { GRUPO DOS MINERAIS TRANSPARENTES NÄO MICÁCEOS: } \\
\text { FREQÜÊNCIA DE CONTAGEM NO GRUPO (\%) }\end{array}$} & \multicolumn{3}{|c|}{$\begin{array}{c}\text { INDICES (i) DE } \\
\text { MATURIDADE QUÍMICA }\end{array}$} & \multicolumn{3}{|c|}{$\begin{array}{c}\text { ÍNDICES (i) DE CONTROLE } \\
\text { (Seleçäo Hidraúlica, } \\
\text { Mudança de Área Fonte e } \\
\text { Maturidade) }\end{array}$} \\
\hline & & ZIR & TUR & RUT & ANA & EST & EPI & GRA & SIL & $\mathrm{ClA}$ & AND & OPX & $\mathrm{CPX}$ & HOR & GLA & ALT & TOTAL & $i Z T R$ & iMET & ilNS & $\mathrm{iTZ}$ & $\mathrm{iRZ}$ & $\mathrm{iHT}$ \\
\hline $1,5-2,5$ & 36 & 6 & 37 & 2 & 3 & 9 & 9 & 1 & 3 & 7 & 2 & 0 & 0 & 17 & 0 & 4 & 100 & 48 & 34 & 18 & 74 & 6 & 52 \\
\hline $2,5-3,5$ & 16 & 4 & 45 & 1 & 3 & 3 & 7 & 0 & 2 & 13 & 2 & 0 & 1 & 17 & 0 & 3 & 100 & 53 & 28 & 19 & 85 & 7 & 40 \\
\hline $3,5-4,5$ & 20 & 2 & 44 & 1 & 1 & 5 & 5 & 1 & 0 & 15 & 2 & 0 & 0 & 20 & 0 & 5 & 100 & 50 & 29 & 21 & 87 & 21 & 47 \\
\hline $4,5-5,5$ & 19 & 1 & 35 & 1 & 4 & 2 & 8 & 0 & 1 & 12 & 1 & 0 & 1 & 31 & 0 & 4 & 100 & 40 & 25 & 35 & 85 & 19 & 39 \\
\hline $6,5-7,5$ & 46 & 6 & 32 & 2 & 2 & 8 & 9 & 2 & 2 & 8 & 0 & 0 & 0 & 24 & 0 & 5 & 100 & 43 & 31 & 26 & 66 & 22 & 41 \\
\hline $7,5-8,5$ & 32 & 7 & 29 & 1 & 5 & 5 & 14 & 0 & 4 & 11 & 5 & 0 & 0 & 19 & 0 & 3 & 100 & 40 & 40 & 20 & 74 & 17 & 44 \\
\hline $8,5-9,5$ & 27 & 8 & 32 & 0 & 4 & 3 & 8 & 0 & 1 & 4 & 2 & 0 & 0 & 38 & 0 & 1 & 100 & 42 & 18 & 40 & 79 & 21 & 46 \\
\hline $9,5-10,5$ & 49 & 6 & 33 & 4 & 3 & 8 & 8 & 0 & 2 & 10 & 1 & 0 & 0 & 22 & 1 & 1 & 100 & 45 & 31 & 24 & 72 & 20 & 38 \\
\hline $10,5-11,5$ & 37 & 5 & 38 & 5 & 1 & 8 & 9 & 0 & 1 & 11 & 0 & 0 & 0 & 14 & 0 & 6 & 100 & 52 & 33 & 16 & 65 & 20 & 37 \\
\hline $11,5-12,5$ & 41 & 12 & 36 & 4 & 1 & 4 & 7 & 1 & 1 & 6 & 1 & 1 & 0 & 22 & 1 & 5 & 100 & 55 & 21 & 25 & 55 & 19 & 40 \\
\hline $12,5-13,5$ & 32 & 5 & 42 & 3 & 5 & 2 & 4 & 0 & 1 & 14 & 0 & 0 & 0 & 14 & 0 & 10 & 100 & 59 & 25 & 16 & 83 & 7 & 37 \\
\hline $13,5-14,5$ & 48 & 10 & 40 & 4 & 2 & 4 & 8 & 1 & 2 & 14 & 0 & 0 & 0 & 12 & 1 & 2 & 100 & 57 & 30 & 13 & 74 & 31 & 37 \\
\hline MÁXIMO & 49 & 12 & 45 & 5 & 5 & 9 & 14 & 2 & 4 & 15 & 5 & 1 & 1 & 38 & 1 & 10 & 100 & 59 & 40 & 40 & 87 & 31 & 52 \\
\hline мі́нммо & 16 & 1 & 29 & 0 & 1 & 2 & 4 & 0 & 0 & 4 & 0 & 0 & 0 & 12 & 0 & 1 & 100 & 40 & 18 & 13 & 55 & 6 & 37 \\
\hline MÉDIA & 34 & 6 & 37 & 2 & 3 & 5 & 8 & 0 & 1 & 10 & 1 & 0 & 0 & 21 & 0 & 4 & 100 & 49 & 29 & 23 & 75 & 17 & 41 \\
\hline D.PADRÄO & 11 & 3 & 5 & 2 & 1 & 3 & 2 & 1 & 1 & 4 & 1 & 0 & 0 & 7 & 0 & 2 & 0 & 7 & 6 & 8 & 10 & 7 & 5 \\
\hline
\end{tabular}

ANEXO 2B. Resultado da contagem de minerais pesados - Amostras do furo de sondagem de Campos Verdes (sem pelíticos). 


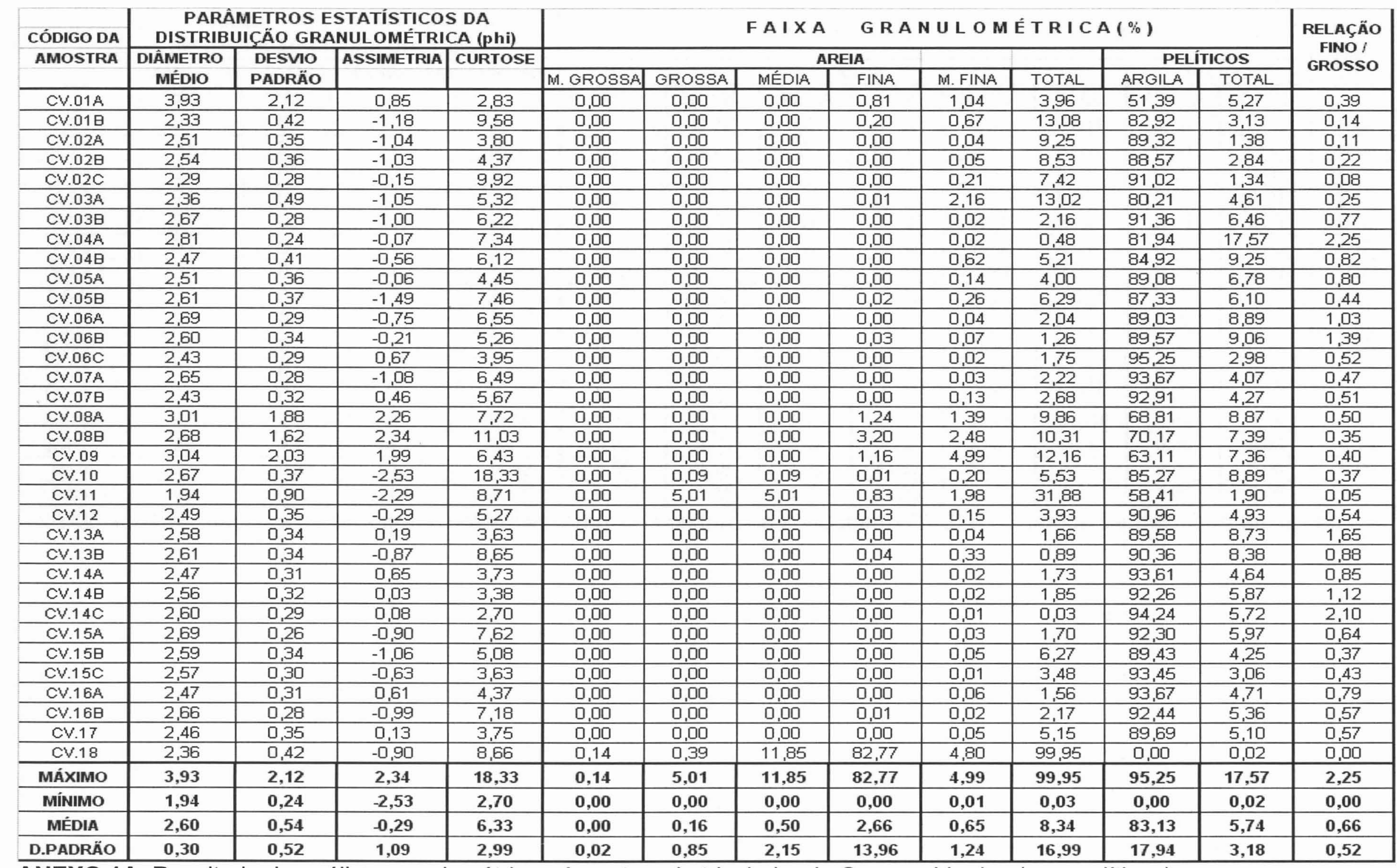

ANEXO 1A. Resultado da análise granulométrica - Amostras de trincheira de Campos Verdes (sem pelíticos). 


\begin{tabular}{|c|c|c|c|c|c|c|c|c|c|c|c|c|c|}
\hline \multirow{3}{*}{$\begin{array}{l}\text { INTERVALO } \\
\text { AMOSTRADO } \\
\text { (m) }\end{array}$} & \multicolumn{4}{|c|}{$\begin{array}{l}\text { PARÂMETROS ESTATÍSTICOS DA } \\
\text { DISTRIBUIÇÄO GRANULOMÉTRICA (phi) }\end{array}$} & \multicolumn{8}{|c|}{ FAIXA } & \multirow{3}{*}{$\begin{array}{l}\text { RELAÇÃO } \\
\text { FINO / } \\
\text { GROSSO }\end{array}$} \\
\hline & \multirow{2}{*}{\begin{tabular}{|c|} 
DIÂMETRO \\
MÉDIO \\
\end{tabular}} & \multirow{2}{*}{$\begin{array}{c}\text { DESVIO } \\
\text { PADRÃO } \\
\end{array}$} & \multirow[t]{2}{*}{ ASSIMETRIA } & \multirow[t]{2}{*}{ CURTOSE } & \multicolumn{4}{|c|}{ AREIA } & \multirow[b]{2}{*}{ M. FINA } & \multirow[b]{2}{*}{ TOTAL } & \multicolumn{2}{|c|}{ PELÍtICOS } & \\
\hline & & & & & M. GROSSA & GROSSA & MÉDIA & FINA & & & ARGILA & TOTAL & \\
\hline $1,5-2,5$ & 2,71 & 0,35 & $-1,16$ & 7,24 & 0,00 & 0,21 & 3,93 & 82,17 & 13,69 & 100,00 & 0,00 & 0,00 & 0,00 \\
\hline $2,5-3,5$ & 2,82 & 0,40 & $-1,80$ & 16,46 & 0,18 & 0,17 & 1,51 & 69,51 & 28,62 & 100,00 & 0,00 & 0,00 & 0,00 \\
\hline $3,5-4,5$ & 2,95 & 0,29 & $-0,23$ & 7,03 & 0,01 & 0,06 & 0,13 & 58,83 & 40,97 & 100,00 & 0,00 & 0,00 & 0,00 \\
\hline $4,5-5,5$ & 2,90 & 0,31 & $-0,30$ & 7,97 & 0,01 & 0,07 & 0,55 & 66,57 & 32,79 & 100,00 & 0,00 & 0,00 & 0,00 \\
\hline $6,5-7,5$ & 2,95 & 0,51 & $-4,05$ & 31,06 & 0,36 & 0,30 & 0,68 & 47,18 & 51,06 & 99,57 & 0,00 & 0,00 & 0,00 \\
\hline $7,5-8,5$ & 2,81 & 0,43 & $-1,23$ & 7,42 & 0,01 & 0,53 & 3,30 & 64,57 & 31,58 & 100,00 & 0,00 & 0,00 & 0,00 \\
\hline $8,5-9,5$ & 3,14 & 0,33 & $-1,75$ & 12,30 & 0,02 & 0,15 & 0,65 & 24,32 & 74,87 & 100,00 & 0,00 & 0,00 & 0,00 \\
\hline $9,5-10,5$ & 3,17 & 0,33 & $-3,32$ & 32,90 & 0,13 & 0,18 & 0,26 & 20,42 & 79,01 & 100,00 & 0,00 & 0,00 & 0,00 \\
\hline $10,5-11,5$ & 3,31 & 0,41 & $-0,80$ & 5,41 & 0,01 & 0,08 & 0,13 & 22,63 & 77,14 & 100,00 & 0,00 & 0,00 & 0,00 \\
\hline $11,5-12,5$ & 3,22 & 0,26 & $-1,12$ & 11,72 & 0,00 & 0,03 & 0,19 & 14,61 & 85,17 & 100,00 & 0,00 & 0,00 & 0,00 \\
\hline $12,5-13,5$ & 3,30 & 0,27 & $-0,30$ & 6,96 & 0,00 & 0,04 & 0,02 & 8,98 & 90,96 & 100,00 & 0,00 & 0,00 & 0,00 \\
\hline $13,5-14,5$ & 3,17 & 0,30 & $-2,59$ & 25,17 & 0,01 & 0,29 & 0,07 & 20,82 & 78,82 & 100,00 & 0,00 & 0,00 & 0,00 \\
\hline MÁXIMO & 3,31 & 0,51 & $-0,23$ & 32,90 & 0,36 & 0,53 & 3,93 & 82,17 & 90,96 & 100,00 & 0,00 & 0,00 & 0,00 \\
\hline MíNIMO & 2,71 & 0,26 & $-4,05$ & 5,41 & 0,00 & 0,03 & 0,02 & 8,98 & 13,69 & 99,57 & 0,00 & 0,00 & 0,00 \\
\hline MÉDIA & 3,04 & 0,35 & $-1,56$ & 14,30 & 0,06 & 0,18 & 0,95 & 41,72 & 57,06 & 99,96 & 0,00 & 0,00 & 0,00 \\
\hline D.PADRÃO & 0,20 & 0,07 & 1,17 & 9,50 & 0,11 & 0,14 & 1,26 & 24,55 & 25,56 & 0,12 & 0,00 & 0,00 & 0,00 \\
\hline
\end{tabular}

ANEXO 1B. Resultado da análise granulométrica - Amostras do furo de sondagem (CVS) de Campos Verdes (sem pelíticos). 


\begin{tabular}{|c|c|c|c|c|c|c|c|c|c|c|c|c|c|}
\hline \multirow{3}{*}{$\begin{array}{l}\text { CÓDIGO DA } \\
\text { AMOSTRA }\end{array}$} & \multicolumn{4}{|c|}{$\begin{array}{l}\text { PARÂMETROS ESTATÍSTICOS DA } \\
\text { DISTRIBUIÇÄO GRANULOMÉTRICA (phi) }\end{array}$} & \multicolumn{8}{|c|}{$F A \mid X A$} & \multirow{3}{*}{$\begin{array}{l}\text { RELAÇÄO } \\
\text { FINO / } \\
\text { GROSSO }\end{array}$} \\
\hline & \multirow{2}{*}{\begin{tabular}{|c|} 
DIÂMETRO \\
MÉDIO \\
\end{tabular}} & \multirow{2}{*}{$\begin{array}{c}\text { DESVIO } \\
\text { PADRÅO }\end{array}$} & \multirow[t]{2}{*}{ ASSIMETRIA } & \multirow[t]{2}{*}{ CURTOSE } & \multicolumn{4}{|c|}{ AREIA } & \multirow[b]{2}{*}{ M. FINA } & \multirow[b]{2}{*}{ TOTAL } & \multicolumn{2}{|c|}{ PELÍTICOS } & \\
\hline & & & & & M. GROSSA & GROSSA & MÉDIA & FINA & & & ARGILA & TOTAL & \\
\hline J.01 & 2,71 & 0,32 & $-2,08$ & 19,71 & 0,10 & 0,09 & 2,38 & 86,78 & 10,54 & 99,88 & 0,00 & 0,12 & 0,00 \\
\hline J.02 & 2,55 & 0,40 & $-0,30$ & 4,06 & 0,00 & 0,24 & 5,46 & 83,14 & 11,07 & 99,92 & 0,00 & 0,08 & 0,00 \\
\hline J.03 & 2,46 & 0,31 & 0,69 & 4,50 & 0,01 & 0,05 & 0,91 & 93,75 & 5,27 & 99,98 & 0,00 & 0,02 & 0,00 \\
\hline Jl.04 & 2,73 & 0,27 & $-0,44$ & 7,60 & 0,01 & 0,01 & 0,51 & 88,50 & 10,90 & 99,93 & 0,00 & 0,07 & 0,00 \\
\hline J.05 & 2,61 & 0,33 & 0,34 & 2,90 & 0,00 & 0,01 & 0,08 & 88,66 & 11,23 & 99,98 & 0,00 & 0,02 & 0,00 \\
\hline J.06 & 2,62 & 0,40 & $-0,19$ & 3,50 & 0,01 & 0,09 & 4,21 & 79,71 & 15,78 & 99,80 & 0,00 & 0,20 & 0,00 \\
\hline J.07 & 2,73 & 0,40 & $-0,92$ & 7,82 & 0,08 & 0,11 & 2,27 & 74,90 & 22,48 & 99,84 & 0,00 & 0,16 & 0,00 \\
\hline ل1.08 & 2,58 & 0,34 & 0,36 & 3,22 & 0,01 & 0,01 & 0,35 & 88,66 & 10,95 & 99,99 & 0,00 & 0,01 & 0,00 \\
\hline ل09 & 2,49 & 0,32 & 0,86 & 3,21 & 0,00 & 0,02 & 0,33 & 91,95 & 7,67 & 99,97 & 0,00 & 0,03 & 0,00 \\
\hline J.10 & 2,52 & 0,30 & 0,61 & 2,60 & 0,00 & 0,00 & 0,07 & 94,31 & 5,60 & 99,99 & 0,00 & 0,01 & 0,00 \\
\hline 11.11 & 2,59 & 0,32 & 0,23 & 3,33 & 0,01 & 0,03 & 0,12 & 90,80 & 9,02 & 99,97 & 0,00 & 0,03 & 0,00 \\
\hline J.12 & 2,61 & 0,33 & 0,21 & 2,98 & 0,00 & 0,04 & 0,34 & 88,33 & 11,28 & 99,98 & 0,00 & 0,02 & 0,00 \\
\hline ل13.13 & 2,77 & 0,21 & 0,19 & 8,68 & 0,00 & 0,01 & 0,06 & 89,21 & 10,68 & 99,96 & 0,00 & 0,04 & 0,00 \\
\hline MÁXIMO & 2,77 & 0,40 & 0,86 & 19,71 & 0,10 & 0,24 & 5,46 & 94,31 & 22,48 & 99,99 & 0,00 & 0,20 & 0,00 \\
\hline MÍNIMO & 2,46 & 0,21 & $-2,08$ & 2,60 & 0,00 & 0,00 & 0,06 & 74,90 & 5,27 & 99,80 & 0,00 & 0,01 & 0,00 \\
\hline MÉDIA & 2,61 & 0,33 & $-0,03$ & 5,70 & 0,02 & 0,06 & 1,31 & 87,59 & 10,96 & 99,94 & 0,00 & 0,06 & 0,00 \\
\hline D.PADRÅO & 0,09 & 0,05 & 0,76 & 4,51 & 0,03 & 0,06 & 1,70 & 5,28 & 4,23 & 0,06 & 0,00 & 0,06 & 0,00 \\
\hline
\end{tabular}

ANEXO 1C. Resultado da análise granulométrica - Amostras de trincheira do Ji (sem pelíticos). 


\begin{tabular}{|c|c|c|c|c|c|c|c|c|c|c|c|c|c|c|c|c|c|c|c|c|c|}
\hline \multirow[t]{2}{*}{$\begin{array}{c}\text { CÓDIGO } \\
\text { DA } \\
\text { AMOSTRA }\end{array}$} & \multirow{2}{*}{\begin{tabular}{|c|} 
MINERAIS \\
OPACOS \\
OPA
\end{tabular}} & \multicolumn{14}{|c|}{$\begin{array}{l}\text { GRUPO DOS MINERAIS TRANSPARENTES NÄO MICÁCEOS: } \\
\text { FREQÜÊNCIA DE CONTAGEM NO GRUPO (\%) }\end{array}$} & \multicolumn{3}{|c|}{$\begin{array}{c}\text { ÍNDICES (i) DE } \\
\text { MATURIDADE QUIMICA }\end{array}$} & \multicolumn{3}{|c|}{$\begin{array}{c}\text { ÍNDICES (i) DE CONTROLE } \\
\text { (Seleçăo Hidraúlica, } \\
\text { Mudança de Área Fonte e } \\
\text { Maturidade) }\end{array}$} \\
\hline & & ZIR & \begin{tabular}{|l|} 
TUR \\
\end{tabular} & RUT & EST & EPI & GRA & \begin{tabular}{|l|} 
SIL \\
\end{tabular} & \begin{tabular}{|l|}
$\mathrm{ClA}$ \\
\end{tabular} & AND & CPX & \begin{tabular}{|l|}
$\mathrm{HOR}$ \\
\end{tabular} & TREM & $\mathrm{ALT}$ & TOTAL & $\mathrm{i} Z \mathrm{TTR}$ & iMET & ilNS & $\mathrm{iTZ}$ & $\mathrm{iRZ}$ & $\mathrm{iHT}$ \\
\hline CV.01A & 53 & 16 & 30 & 3 & 19 & 10 & 1 & 1 & 4 & 0 & 0 & 13 & 0 & 3 & 100 & 50 & 36 & 14 & 91 & 10 & 10 \\
\hline CV.01B & 32 & 9 & 48 & 1 & 14 & 16 & 0 & 0 & 1 & 0 & 0 & 4 & 0 & 7 & 100 & 63 & 33 & 4 & - & - & - \\
\hline CV.02A & 22 & 12 & 44 & 3 & 9 & 13 & 2 & 2 & 7 & 0 & 0 & 4 & 0 & 6 & 100 & 62 & 34 & 4 & 82 & 13 & 35 \\
\hline CV.02B & 30 & 9 & 23 & 6 & 11 & 21 & 1 & 0 & 7 & 1 & 1 & 12 & 1 & 7 & 100 & 41 & 43 & 15 & 76 & 20 & 31 \\
\hline CV.02C & 34 & 9 & 35 & 3 & 13 & 15 & 1 & 1 & 5 & 0 & 1 & 12 & 0 & 5 & 100 & 48 & 38 & 13 & 88 & 29 & 24 \\
\hline CV.03A & 27 & 6 & 26 & 0 & 2 & 14 & 0 & 3 & 13 & 0 & 0 & 21 & 2 & 15 & 100 & 38 & 36 & 26 & 89 & 5 & 42 \\
\hline CV.03B & 16 & 6 & 28 & 2 & 3 & 17 & 0 & 0 & 8 & 0 & 0 & 19 & 0 & 18 & 100 & 43 & 34 & 23 & - & - & - \\
\hline CV.04A & 10 & 5 & 43 & 1 & 2 & 14 & 0 & 3 & 4 & 0 & 0 & 15 & 0 & 13 & 100 & 57 & 26 & 17 & - & - & - \\
\hline CV.04B & 13 & 8 & 37 & 3 & 7 & 12 & 0 & 3 & 7 & 0 & 0 & 15 & 0 & 7 & 100 & 52 & 32 & 16 & 87 & 22 & 33 \\
\hline CV.05A & 12 & 8 & 30 & 3 & 4 & 16 & 0 & 1 & 4 & 0 & 0 & 13 & 2 & 19 & 100 & 51 & 31 & 19 & 95 & 28 & 38 \\
\hline CV.05B & 17 & 7 & 36 & 2 & 5 & 10 & 0 & 0 & 7 & 0 & 0 & 22 & 3 & 9 & 100 & 49 & 24 & 27 & - & - & - \\
\hline CV.06A & 46 & 19 & 35 & 3 & 6 & 18 & 1 & 2 & 7 & 0 & 0 & 8 & 0 & 2 & 100 & 57 & 34 & 8 & 88 & 32 & 22 \\
\hline CV.06B & 32 & 10 & 43 & 4 & 9 & 12 & 0 & 3 & 5 & 0 & 0 & 10 & 0 & 4 & 100 & 59 & 31 & 10 & - & - & - \\
\hline CV.06C & 21 & 9 & 42 & 3 & 4 & 18 & 1 & 0 & 5 & 0 & 0 & 11 & 1 & 6 & 100 & 58 & 29 & 13 & - & - & - \\
\hline CV.07A & 51 & 24 & 26 & 6 & 11 & 15 & 0 & 1 & 9 & 0 & 0 & 6 & 0 & 3 & 100 & 57 & 37 & 6 & 54 & 21 & 50 \\
\hline CV.07B & 50 & 22 & 32 & 4 & 6 & 16 & 0 & 0 & 7 & 0 & 0 & 12 & 0 & 1 & 100 & 59 & 29 & 12 & - & - & - \\
\hline CV.08A & 34 & 22 & 34 & 3 & 5 & 14 & 1 & 2 & 5 & 0 & 0 & 11 & 0 & 3 & 99 & 61 & 27 & 12 & 64 & 11 & 21 \\
\hline CV.08B & 34 & 17 & 33 & 4 & 8 & 14 & 1 & 1 & 7 & 1 & 0 & 10 & 0 & 5 & 100 & 56 & 33 & 10 & 78 & 26 & 20 \\
\hline CV.09 & 35 & 22 & 35 & 4 & 4 & 13 & 0 & 2 & 5 & 1 & 0 & 7 & 0 & 6 & 100 & 66 & 27 & 8 & 73 & 22 & 18 \\
\hline CV.10 & 32 & 10 & 40 & 6 & 13 & 11 & 0 & 1 & 7 & 1 & 0 & 6 & 0 & 5 & 100 & 59 & 35 & 6 & 77 & 5 & 16 \\
\hline CV.11 & 38 & 7 & 64 & 6 & 11 & 3 & 0 & 1 & 6 & 0 & 1 & 1 & 0 & 1 & 100 & 78 & 20 & 2 & 89 & 12 & 12 \\
\hline CV.12 & 25 & 7 & 44 & 4 & 3 & 15 & 0 & 1 & 9 & 0 & 0 & 14 & 0 & 4 & 100 & 57 & 29 & 14 & 84 & 19 & 29 \\
\hline CV.13A & 28 & 15 & 28 & 9 & 3 & 13 & 1 & 1 & 10 & 0 & 0 & 20 & 0 & 1 & 100 & 52 & 27 & 20 & - & - & - \\
\hline CV.13B & 29 & 14 & 29 & 4 & 11 & 18 & 0 & 0 & 5 & 0 & 0 & 15 & 0 & 3 & 100 & 50 & 35 & 16 & 82 & 12 & 38 \\
\hline CV.14A & 38 & 39 & 22 & 6 & 4 & 8 & 1 & 0 & 5 & 0 & 0 & 13 & 0 & 3 & 100 & 69 & 18 & 13 & 47 & 10 & 15 \\
\hline CV.14B & 48 & 34 & 27 & 4 & 7 & 8 & 0 & 0 & 5 & 0 & 1 & 10 & 0 & 4 & 100 & 68 & 21 & 11 & 67 & 15 & 14 \\
\hline CV.14C & 39 & 33 & 22 & 1 & 7 & 14 & 0 & 1 & 4 & 0 & 0 & 14 & 0 & 2 & 99 & 58 & 26 & 16 & 56 & 9 & 19 \\
\hline CV.15A & 16 & 12 & 47 & 1 & 3 & 14 & 0 & 0 & 2 & 0 & 0 & 10 & 1 & 10 & 100 & 67 & 21 & 12 & 92 & 19 & 12 \\
\hline CV.15B & 35 & 19 & 33 & 6 & 6 & 10 & 0 & 1 & 3 & 0 & 0 & 7 & 0 & 15 & 100 & 68 & 23 & 9 & - & - & - \\
\hline CV.15C & 36 & 14 & 57 & 5 & 3 & 11 & 1 & 0 & 2 & 0 & 0 & 7 & 0 & 1 & 100 & 77 & 16 & 7 & 86 & 21 & 10 \\
\hline CV.16A & 41 & 34 & 37 & 4 & 6 & 8 & 0 & 0 & 4 & 0 & 0 & 5 & 0 & 2 & 100 & 76 & 18 & 5 & - & - & - \\
\hline CV.16B & 44 & 22 & 36 & 6 & 7 & 12 & 1 & 0 & 5 & 0 & 0 & 7 & 0 & 5 & 100 & 67 & 25 & 8 & 63 & 18 & 21 \\
\hline CV.17 & 35 & 22 & 36 & 6 & 8 & 6 & 0 & 0 & 6 & 0 & 0 & 12 & 1 & 5 & 100 & 66 & 20 & 14 & 76 & 23 & 29 \\
\hline CRN.02A & 34 & 19 & 39 & 5 & 7 & 12 & 0 & 1 & 3 & 0 & 0 & 6 & 0 & 5 & 99 & 66 & 26 & 8 & - & - & - \\
\hline CV.18 & 53 & 55 & 18 & 6 & 4 & 9 & 0 & 0 & 3 & 1 & 0 & 4 & 0 & 0 & 99 & 79 & 17 & 4 & 32 & 5 & 23 \\
\hline MÁXIMO & 53 & 55 & 64 & 9 & 19 & 21 & 2 & 3 & 13 & 1 & 1 & 22 & 3 & 19 & 100 & 79 & 43 & 27 & 95 & 32 & 50 \\
\hline MíNIMO & 10 & 5 & 18 & 0 & 2 & 3 & 0 & 0 & 1 & 0 & 0 & 1 & 0 & 0 & 99 & 38 & 16 & 2 & 32 & 5 & 10 \\
\hline MÉDIA & 33 & 17 & 35 & 4 & 7 & 13 & 0 & 1 & 5 & 0 & 0 & 11 & 0 & 6 & 100 & 60 & 28 & 12 & 75 & 17 & 24 \\
\hline D.PADRÃO & 12 & 11 & 10 & 2 & 4 & 4 & 0 & 1 & 2 & 0 & 0 & 5 & 1 & 5 & 0 & 10 & 7 & 6 & 16 & 8 & 11 \\
\hline
\end{tabular}

ANEXO 2A. Resultado da contagem de minerais pesados - Amostras de trincheira de Campos Verdes (sem pelíticos). 


\begin{tabular}{|c|c|c|c|c|c|c|c|c|c|c|c|c|c|c|c|c|c|c|c|c|c|c|c|}
\hline \multirow[t]{2}{*}{$\begin{array}{c}\text { INTERVALO } \\
\text { AMOSTRAD0 } \\
\text { (m) }\end{array}$} & \multirow{2}{*}{$\begin{array}{c}\text { MINERAIS } \\
\text { OPACOS } \\
\text { OPA } \\
\end{array}$} & \multicolumn{16}{|c|}{$\begin{array}{l}\text { GRUPO DOS MINERAIS TRANSPARENTES NÄO MICÁCEOS: } \\
\text { FREQÜÊNCIA DE CONTAGEM NO GRUPO (\%) }\end{array}$} & \multicolumn{3}{|c|}{$\begin{array}{c}\text { INDICES (i) DE } \\
\text { MATURIDADE QUÍMICA }\end{array}$} & \multicolumn{3}{|c|}{$\begin{array}{c}\text { ÍNDICES (i) DE CONTROLE } \\
\text { (Seleçäo Hidraúlica, } \\
\text { Mudança de Área Fonte e } \\
\text { Maturidade) }\end{array}$} \\
\hline & & ZIR & TUR & RUT & ANA & EST & EPI & GRA & SIL & $\mathrm{ClA}$ & AND & OPX & $\mathrm{CPX}$ & HOR & GLA & ALT & TOTAL & $i Z T R$ & iMET & ilNS & $\mathrm{iTZ}$ & $\mathrm{iRZ}$ & $\mathrm{iHT}$ \\
\hline $1,5-2,5$ & 36 & 6 & 37 & 2 & 3 & 9 & 9 & 1 & 3 & 7 & 2 & 0 & 0 & 17 & 0 & 4 & 100 & 48 & 34 & 18 & 74 & 6 & 52 \\
\hline $2,5-3,5$ & 16 & 4 & 45 & 1 & 3 & 3 & 7 & 0 & 2 & 13 & 2 & 0 & 1 & 17 & 0 & 3 & 100 & 53 & 28 & 19 & 85 & 7 & 40 \\
\hline $3,5-4,5$ & 20 & 2 & 44 & 1 & 1 & 5 & 5 & 1 & 0 & 15 & 2 & 0 & 0 & 20 & 0 & 5 & 100 & 50 & 29 & 21 & 87 & 21 & 47 \\
\hline $4,5-5,5$ & 19 & 1 & 35 & 1 & 4 & 2 & 8 & 0 & 1 & 12 & 1 & 0 & 1 & 31 & 0 & 4 & 100 & 40 & 25 & 35 & 85 & 19 & 39 \\
\hline $6,5-7,5$ & 46 & 6 & 32 & 2 & 2 & 8 & 9 & 2 & 2 & 8 & 0 & 0 & 0 & 24 & 0 & 5 & 100 & 43 & 31 & 26 & 66 & 22 & 41 \\
\hline $7,5-8,5$ & 32 & 7 & 29 & 1 & 5 & 5 & 14 & 0 & 4 & 11 & 5 & 0 & 0 & 19 & 0 & 3 & 100 & 40 & 40 & 20 & 74 & 17 & 44 \\
\hline $8,5-9,5$ & 27 & 8 & 32 & 0 & 4 & 3 & 8 & 0 & 1 & 4 & 2 & 0 & 0 & 38 & 0 & 1 & 100 & 42 & 18 & 40 & 79 & 21 & 46 \\
\hline $9,5-10,5$ & 49 & 6 & 33 & 4 & 3 & 8 & 8 & 0 & 2 & 10 & 1 & 0 & 0 & 22 & 1 & 1 & 100 & 45 & 31 & 24 & 72 & 20 & 38 \\
\hline $10,5-11,5$ & 37 & 5 & 38 & 5 & 1 & 8 & 9 & 0 & 1 & 11 & 0 & 0 & 0 & 14 & 0 & 6 & 100 & 52 & 33 & 16 & 65 & 20 & 37 \\
\hline $11,5-12,5$ & 41 & 12 & 36 & 4 & 1 & 4 & 7 & 1 & 1 & 6 & 1 & 1 & 0 & 22 & 1 & 5 & 100 & 55 & 21 & 25 & 55 & 19 & 40 \\
\hline $12,5-13,5$ & 32 & 5 & 42 & 3 & 5 & 2 & 4 & 0 & 1 & 14 & 0 & 0 & 0 & 14 & 0 & 10 & 100 & 59 & 25 & 16 & 83 & 7 & 37 \\
\hline $13,5-14,5$ & 48 & 10 & 40 & 4 & 2 & 4 & 8 & 1 & 2 & 14 & 0 & 0 & 0 & 12 & 1 & 2 & 100 & 57 & 30 & 13 & 74 & 31 & 37 \\
\hline MÁXIMO & 49 & 12 & 45 & 5 & 5 & 9 & 14 & 2 & 4 & 15 & 5 & 1 & 1 & 38 & 1 & 10 & 100 & 59 & 40 & 40 & 87 & 31 & 52 \\
\hline мі́нммо & 16 & 1 & 29 & 0 & 1 & 2 & 4 & 0 & 0 & 4 & 0 & 0 & 0 & 12 & 0 & 1 & 100 & 40 & 18 & 13 & 55 & 6 & 37 \\
\hline MÉDIA & 34 & 6 & 37 & 2 & 3 & 5 & 8 & 0 & 1 & 10 & 1 & 0 & 0 & 21 & 0 & 4 & 100 & 49 & 29 & 23 & 75 & 17 & 41 \\
\hline D.PADRÄO & 11 & 3 & 5 & 2 & 1 & 3 & 2 & 1 & 1 & 4 & 1 & 0 & 0 & 7 & 0 & 2 & 0 & 7 & 6 & 8 & 10 & 7 & 5 \\
\hline
\end{tabular}

ANEXO 2B. Resultado da contagem de minerais pesados - Amostras do furo de sondagem de Campos Verdes (sem pelíticos). 


\begin{tabular}{|c|c|c|c|c|c|c|c|c|c|c|c|c|c|c|c|c|c|c|c|c|c|}
\hline \multirow[t]{2}{*}{$\begin{array}{c}\text { CÓDIGO } \\
\text { DA } \\
\text { AMOSTRA }\end{array}$} & \multirow[t]{2}{*}{\begin{tabular}{|c|} 
MINERAIS \\
OPACOS \\
OPA \\
\end{tabular}} & \multicolumn{14}{|c|}{$\begin{array}{l}\text { GRUPO DOS MINERAIS TRANSPARENTES NÄO MICÁCEOS: } \\
\text { FREQÜÊNCIA DE CONTAGEM NO GRUPO (\%) }\end{array}$} & \multicolumn{3}{|c|}{$\begin{array}{c}\text { ÍNDICES (i) DE } \\
\text { MATURIDADE } \\
\text { QUIMICA }\end{array}$} & \multicolumn{3}{|c|}{$\begin{array}{c}\text { ÍNDICES (i) DE } \\
\text { CONTROLE (Seleção } \\
\text { Hidraúlica, Mudança } \\
\text { de Área Fonte e } \\
\text { Maturidade) }\end{array}$} \\
\hline & & $\mathrm{ZIR}$ & TUR & RUT & EST & EPI & GRA & SIL & $\mathrm{C} \mid \mathrm{A}$ & AND & OPX & CPX & $\mathrm{HOR}$ & ALT & TOTAL & iZTR & iMET & ilNS & $\mathrm{iTZ}$ & $\mathrm{iRZ}$ & $\mathrm{iHT}$ \\
\hline J.01 & 65 & 42 & 31 & 12 & 2 & 8 & 0 & 1 & 1 & 0 & 0 & 0 & 3 & 0 & 100 & 85 & 12 & 3 & 39 & 25 & 5 \\
\hline J.02 & 62 & 50 & 21 & 2 & 3 & 6 & 0 & 2 & 8 & 1 & 2 & 0 & 5 & 1 & 100 & 73 & 19 & 7 & 34 & 4 & 23 \\
\hline J.03 & 52 & 31 & 23 & 7 & 5 & 14 & 0 & 1 & 4 & 0 & 2 & 0 & 9 & 3 & 100 & 61 & 24 & 11 & 39 & 13 & 28 \\
\hline J.04 & 36 & 22 & 19 & 3 & 1 & 16 & 0 & 3 & 5 & 0 & 1 & 1 & 23 & 5 & 100 & 44 & 25 & 26 & 55 & 22 & 45 \\
\hline J.05 & 45 & 30 & 21 & 3 & 3 & 13 & 0 & 0 & 7 & 0 & 3 & 1 & 15 & 3 & 100 & 55 & 23 & 20 & 56 & 28 & 33 \\
\hline J.06 & 56 & 46 & 13 & 10 & 1 & 14 & 0 & 0 & 2 & 0 & 1 & 1 & 11 & 3 & 100 & 68 & 17 & 13 & 36 & 25 & 40 \\
\hline J.07 & 36 & 24 & 29 & 2 & 4 & 20 & 0 & 0 & 2 & 0 & 2 & 0 & 15 & 3 & 100 & 54 & 26 & 17 & 51 & 12 & 50 \\
\hline J.08 & 31 & 13 & 25 & 3 & 5 & 15 & 0 & 5 & 9 & 0 & 1 & 0 & 17 & 7 & 100 & 41 & 34 & 18 & 77 & 22 & 32 \\
\hline J.09 & 47 & 23 & 25 & 10 & 2 & 14 & 1 & 1 & 7 & 0 & 5 & 1 & 8 & 4 & 100 & 58 & 25 & 14 & 55 & 19 & 28 \\
\hline J.10 & 30 & 5 & 21 & 2 & 4 & 17 & 0 & 0 & 12 & 0 & 3 & 5 & 22 & 9 & 100 & 28 & 33 & 30 & 67 & 22 & 44 \\
\hline J.11 & 37 & 15 & 19 & 5 & 3 & 12 & 2 & 0 & 5 & 0 & 2 & 0 & 33 & 3 & 100 & 39 & 22 & 36 & 60 & 15 & 46 \\
\hline ل12 & 33 & 14 & 30 & 1 & 10 & 16 & 1 & 4 & 5 & 0 & 0 & 0 & 14 & 5 & 100 & 45 & 36 & 14 & 53 & 17 & 42 \\
\hline ل13.13 & 24 & 4 & 33 & 0 & 7 & 16 & 0 & 5 & 5 & 0 & 0 & 2 & 23 & 5 & 100 & 37 & 33 & 25 & 62 & 10 & 34 \\
\hline MÁXIMO & 65 & 50 & 33 & 12 & 10 & 20 & 2 & 5 & 12 & 1 & 5 & 5 & 33 & 9 & 100 & 85 & 36 & 36 & 77 & 28 & 50 \\
\hline MÍNIMO & 24 & 4 & 13 & 0 & 1 & 6 & 0 & 0 & 1 & 0 & 0 & 0 & 3 & 0 & 100 & 28 & 12 & 3 & 34 & 4 & 5 \\
\hline MÉDIA & 43 & 25 & 24 & 5 & 4 & 14 & 0 & 2 & 5 & 0 & 2 & 1 & 15 & 4 & 100 & 53 & 25 & 18 & 52 & 18 & 35 \\
\hline D.PADRẢO & 13 & 15 & 6 & 4 & 3 & 4 & 1 & 2 & 3 & 0 & 1 & 1 & 9 & 2 & 0 & 16 & 7 & 9 & 13 & 7 & 12 \\
\hline
\end{tabular}

ANEXO 2C. Resultado da contagem de minerais pesados - Amostras de trincheira do Ji (sem pelíticos). 


\begin{tabular}{|c|c|c|c|c|c|c|c|c|c|c|}
\hline Amostra & Th $\quad(p p m)$ & U (ppm) & $(\%)$ & Teor umidade & $\begin{array}{c}\text { DR cósmica } \\
\text { (mGy/a) }\end{array}$ & $\begin{array}{c}\text { DR beta eff } \\
\text { (mGy/a) }\end{array}$ & $\begin{array}{c}\text { DR gamma eff } \\
\text { (mGy/a) }\end{array}$ & DR (mGy/a) & $\begin{array}{c}\text { Dose total } \\
\text { (Gy) }\end{array}$ & Idade (ano \\
\hline & $54087 \pm 0,21093$ & 7357 & , & & $1662 \pm 0,00831$ & $0,29707 \pm 0,03026$ & $0,13033 \pm 0,01592$ & & $1,155 \pm 0,048$ & \\
\hline & $93669 \pm 0,29715$ & $0,34607 \pm 1$ & $0,48478 \pm 0,03578$ & & $1628 \pm 0,00814$ & $0,41616 \pm 0,03692$ & $0,19063=$ & $0,76959 \pm$ & 2,167 & \\
\hline & $96966 \pm 0,24379$ & $0,241 \pm 0$, & $\pm 0,0$ & & $1633 \pm$ & $0,3399 \pm$ & 0,16246 & 0,6656 & 1,839 & 205 \\
\hline & $0,83251 \pm 0,2689$ & $9,31383 \pm 0$ & $0,40688 \pm 0,03594$ & & 7814 & $0,35322 \pm$ & $0,16458 \pm$ & & & 277 \\
\hline CV-08 & $0,7706 \pm 0,0685$ & $0,1736 \pm 0$ & $0,3488 \pm 0,0155$ & &, 1679 & 0,28101 & 0,130 & 0,579 & 1,30 & 123 \\
\hline &, $56773 \pm 0$ & $0,19787 \pm$ & $0,33277 \pm 0$ & & 0,1697 & 0,27458 & 0,123 & 345 & 0,20 & \\
\hline & 0,8326 & 174 & $0,194 \pm 0,0$ & & 43 & 0,1854 & & 0,46 & $1,93 t$ & 347 \\
\hline & 0,7274 & 0,471 & $, 46559 \pm 0,0$ & & & & & & & \\
\hline & 1,130 & 0,261 & 0,49467 & & 0,17 & 0,4103 & 0,19 & 0,77 & 0,13 & \\
\hline & $1,77361 \pm 0$ & $0,39956 \pm 0$ & $0,36809 \pm 0,0327$ & & 0,1678 & 0,35639 & 0,207 & 0,7 & 1,26 & 119 \\
\hline & $1,24282 \pm 0$, & $0,25646 \pm 0$ & $0,33056 \pm 0,03446$ & & 0165 & 0,29448 & 0,159 & 0,61 & 0,22 & 50 \\
\hline & $0,8446 \pm 0$ & $0,2604 \pm 0$ & 0,0157 & & 166 & 0,1844 & & 0,45 & 2,22 & 270 \\
\hline & $0,5869 \pm$ & $0,1697 \pm 0$ & $\pm 0,0108$ & & 171 & 0,15946 & 0,08 & 0,4 & 1,15 & 151 \\
\hline & $0,7324 \pm 0$ & $0,1746 \pm 0$ & 0,32 & & 0,1696 & 0,2311 & 0,109 & 0,51 & 0,526 & 55 \\
\hline & $0,7575 \pm$ & & $\pm 0,0139$ & & 0,1679 & 0,2670 & 0,1283 & 0,56 & 0,758 & \\
\hline & $0,8414 \pm 0$ & 0,25 & 0,299 & & 52 & 0,21727 & 0,11 & 0,49 & 1,268 & 140 \\
\hline & $0,7777 \pm 0$ & $0,1903 \pm 0$ & $\pm 0,015$ & & 0,1664 & 0,25521 & 0,1196 & 0,5 & 0,450 & \\
\hline JI-13 & $0,6944 \pm 0,0627$ & $0,1691 \pm 0,018$ & $0,3743 \pm 0,0132$ & 1,02 & 0,1653 & $0,26309 \pm 0,0102$ & $0,11867 \pm 0,00459$ & 0,54 & $0,411=$ & \\
\hline
\end{tabular}

ANEXO 3A. Resultado obtidos por datação LOE.

\begin{tabular}{|c|c|c|c|c|c|c|c|c|}
\hline \multirow{2}{*}{ Amostras } & \multirow{2}{*}{ Feixes } & \multirow{2}{*}{\begin{tabular}{|c|} 
Distância \\
$(\mathrm{m})$
\end{tabular}} & \multicolumn{3}{|c|}{ Período (anos) } & \multicolumn{3}{|c|}{ Taxa de progradaçâo (m/anos) } \\
\hline & & & $\min$ & $\max$ & med & $\min$ & $\max$ & med \\
\hline CV.18-CV.11 & 14 & 1740 & 96 & 1330 & 713 & 18,13 & 1,31 & 2,44 \\
\hline CV.18-CV.07 & 14 & 1560 & 912 & 2006 & 1459 & 1,71 & 0,78 & 1,07 \\
\hline CV.11-CV.07 & $13,12,11$ & 500 & 122 & 1370 & 746 & 4,10 & 0,36 & 0,67 \\
\hline CV.11-CV.06 & & 510 & 884 & 1988 & 1436 & 0,58 & 0,26 & 0,36 \\
\hline CV.07-CV.06 & $13,12,11$ & 1000 & 208 & 1172 & 690 & 4,81 & 0,85 & 1,45 \\
\hline CV.06-CV.05 & $6,7,8,9,10$ & 1190 & -451 & 345 & -53 & $-2,64$ & 3,45 & $-22,45$ \\
\hline CV.05-CV.02 & $1,2,3,4,5$ & 662 & 536 & 1204 & 870 & 1,24 & 0,55 & 0,76 \\
\hline I.02 - الـ.06 & 5,4 & 580 & -34 & 548 & 257 & $-17,06$ & 1,06 & 2,26 \\
\hline J.06 - الـ.03 & 3 & 420 & 1311 & 1701 & 1506 & 0,32 & 0,25 & 0,28 \\
\hline ل11.03 - 11.03 & 2 & 360 & 102 & 298 & 200 & 3,53 & 1,21 & 1,80 \\
\hline Jl.11 - atual & 1 & 1220 & 788 & 874 & 831 & 1,55 & 1,40 & 1,47 \\
\hline
\end{tabular}

ANEXO 3B. Parâmetros medidos para o calculo das taxas de progradação e taxas calculadas. 
ANEXO 4A. Estrutura do programa ( $\mathrm{mcmc}$.py) que promove trocas sedimentares entre compartimentos, utilizado para simulação geral.

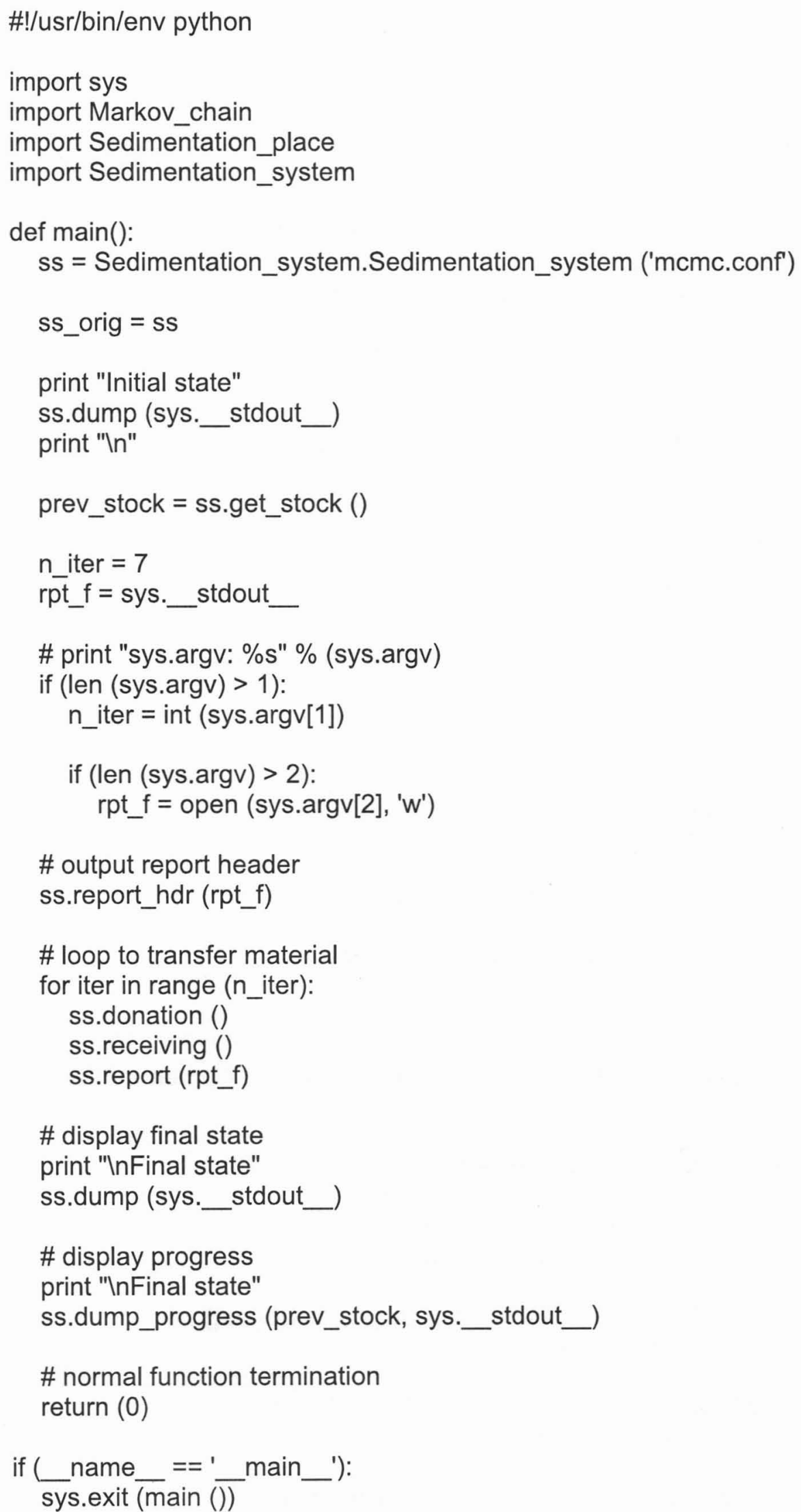

\# display final state print "InFinal state" ss.dump (sys.__stdout__

\# display progress

print "InFinal state"

ss.dump_progress (prev_stock, sys._stdout_)

\# normal function termination return (0)

if $\left(\underset{\text { sys.exit }(\text { main }}{\text { name }}={ }^{\prime}\right.$ main_- $)$ : 
ANEXO 4B. Módulo (Sedimentation_system.py) que representa um sistema deposicional do programa.

\#!/usr/bin/env python

import sys

import Markov_chain

import Sedimentation_place

class Sedimentation_system:

"'"' A system of sedimentation places, iterates over them "'"' def__init__(self, inp_nam):

"'"' constructor step, reads parameters from file "'""

\# TODO: get the name from command line

$f=$ open ("mcmc.conf", "r")

\# TODO: use a fancier input for config, possibly XML

\# input System order

$\mathrm{s}=$ f.readline ()

fields = s.split (';')

\# TODO: try/catch block to deal with formatting problems

self.order $=$ int (fields[0])

\# TODO: input Markov matrix

markarr $=$ []

for row in range (self.order):

$\mathrm{s}=\mathrm{f}$.readline ()

\# TODO: raise an exception in case of EOF

\# split values separated by semi-colons

fields = s.split (';')

$\#$ print 'fields $=\% s^{\prime} \%$ fields

order

\# TODO: raise an exception in case number of elements differs from

\# convert strings to numbers

prob $=[]$

for ind in range (len (fields) - 1):

\# OBS: last field is linefeed

\# print "fields[\%d] = \%s" \% (ind, fields[ind])

prob.append ( float (fields[ind]) )

\# add to Markov chain array

markarr.append (prob)

\# TODO: create an instance of Markov chain, from

$\mathrm{mc}=$ Markov_chain.Markov_chain (markarr) 
\# input name, maximum, minimum and quantum for each sedimentation place

self.place $=[]$

for ind in range (self.order):

\# input a sedimentation place line

$s=$ f.readline ()

\# TODO: raise an exception in case not enough lines

\# split values separated by semi-colons

$v=$ s.split (';')

\# print "v $=\%$ s" \% (v)

\# TODO:r raise an exception in case not enough lines

\# build sedimentation place

\# (mc, id, desc, stock, minimum, maximum, quantum):

for ind in range (len (v) - 1):

if (ind $==1$ ):

continue

$\mathrm{v}[$ ind $]=$ float $(\mathrm{v}[$ ind $])$

$\mathrm{v}[0]=\operatorname{int}(\mathrm{v}[0])$

$\mathrm{sp}=$ Sedimentation_place.Sedimentation_place (mc, v[0], v[1], v[2], v[3],

$v[4], v[5])$

\# append sp to Sedimentation place matrix

self.place.append (sp)

\# closes open input file

f.close ()

\# normal function termination

return

def donation (self):

"'"' Iterates over all places, to find whether they'll give"'"'

\# for each node, select a destination, and try to save material in its pre buffer.

for ind in range (self.order):

donor $=$ self.place [ind $]$

destination, material, freq = donor.try_giving ()

receiver $=$ self.place[destination]

was_received $=$ receiver.receive (material)

$r c="--$ refused"

if (was_received):

rc = " -- received"

donor.do_give (True)

material \%f \%s" \%।

print "Sedimentation_system.donation(): donor \%d, receiver \%d. 


\section{(ind, destination, material, rc)}

\# normal function termination return

def receiving (self):

"'"' Iterates over all places, to find whether they'll receive"'"' \# for each node incorporate its pre buffer.

for ind in range (self.order):

receiver $=$ self.place[ind $]$

receiver.incorporate ()

\# normal function termination

return

def report_hdr (self, f):

"'"'Output header of report"'"'

$\mathrm{hdr}="$

for ind in range (self.order):

hdr $=$ hdr + '"' + self.place[ind].get_desc ()

hdr = hdr + "'; '

$h d r=h d r+$ 'In'

f.write (hdr)

\# normal function termination

return

def report (self, f):

"'"' Dump the sedimentation system to an already open file "'""

\# TODO: USE $f$ !!!

\# TODO: confirm $\mathrm{f}$ is open, otherwise raise an exception

\# TODO: header for report

\# for each node, report its contents

line $="$

for ind in range (self.order):

line $=$ line + `self.place[ind].get_stock ()`

line = line $+"$; "

line $=$ line + 'In'

f.write (line)

\# normal function termination

return

def dump (self, f):

"'"' Dump the sedimentation system to an already open file "'"' 
\# TODO: USE f !!!

\# TODO: confirm $f$ is open, otherwise raise an exception

\# TODO: header for report

\# for each node, report its contents

for ind in range (self.order):

print "\%s" \% (self.place[ind])

\# normal function termination

return

def get_stock (self):

"'"' Save system places' stock, for further comparison "'"'

\# for each node, report its contents

result $=$ []

for ind in range (self.order):

result.append (self.place[ind].get_stock ())

return (result)

def subtract (self, other):

"'"' Subtract the stock of current sedimentation system places from another. Returns sequence with the results "'"'

\# TODO: confirm systems are of same size

\# for each node, report its contents

result $=[]$

for ind in range (self.order):

result.append (self.place[ind].subtract (other.place[ind]))

\# normal function termination

return (result)

def calc_progress (self, prev_stock):

"'"' Subtract the stock of current sedimentation system places from previous

value. Returns sequence with the results "'"'

\# TODO: confirm system and stock are of same size

\# for each node, calculate its progress

result $=[]$

for ind in range (self.order):

result.append (self.place[ind].calc_progress (prev_stock[ind]))

\# normal function termination

return (result)

def dump_progress (self, prev_stock, f):

"'"' Subtract the stock of current sedimentation system places from previous value. Returns sequence with the results "'"' 
\# TODO: USE $f$ !!!

\# TODO: confirm $f$ is open, otherwise raise an exception

\# TODO: confirm system and stock are of same size

\# TODO: print progress

\# calculate progress

progress $=$ self.calc_progress (prev_stock)

\# for each node, report its contents

for ind in range (self.order):

$$
\begin{aligned}
& \mathrm{s}=\text { self.place[ind].show_state () } \\
& \mathrm{s}=\mathrm{s}+\text { +; " + "progress[ind]" }
\end{aligned}
$$

print "\%s" \% (s)

\# normal function termination

return

def main():

\# TODO: do some testing of class Sedimentation_system print 'Hello world!'

\# normal function termination

return $(0)$

if ( $\_$name__ $==$'_main__'):

sys.exit (main ()) 
ANEXO 4C. Módulo (Sedimentation_place.py) que representa um compartimento (mar, praia, continente, campo de dunas1, campo de dunas2) do programa.

\#!/usr/bin/env python

import sys

import Markov_chain

class Sedimentation_place:

"'"'Place of sedimentation, either for receiving or giving material. "'"'

def__init_(self, mc, id, desc, stock, minimum, maximum, quantum):

"'"' constructor, associates with a given Markov chain"'"'

self.mc $=m c$ \# the Markov chain matrix

self.id $=$ id \# object id, equivalent to row in MC matrix

self.desc $=$ desc

self.stock = stock \# initial stock of sediments

self.minimum = minimum \# minimum stock of material

self.maximum = maximum \# maximum stock of material

self.quantum = quantum \# quantum to transfer per iteration

self.pre_buf $=0 \quad$ \# holds material received

self.aproval = False \# was transfer received ?

return

def str_ (self):

result $="$

result $=\quad$ 'self.id' + ': '

result = result + "'"' + self.desc + "'; "

result $=$ result + "stock " + 'self.stock' + "; "

result = result + "min " + 'self.minimum " +"; "

result = result + "max" + 'self.maximum" + "; "

result = result + "quantum " + 'self.quantum` + "; "

return (result)

def get_id (self):

return (self.id)

def get_desc (self):

return (self.desc)

def get_stock (self):

return (self.stock)

def get_minimum (self):

return (self.minimum)

def get maximum (self):

return (self.maximum)

def get_quantum (self):

return (self.quantum) 
def show_state (self):

"'"' Yield as a string the current stock as well place's identification "'"'

result $="$

result $=$ result + `self.id + " " "

result $=$ result + self.desc $+"): "$

result $=$ result + 'self.stock'

return (result)

def subtract (self, other):

"'"' Subtract the current place's stock from another place: this - other "'"'

\# TODO: compare id and desc; raise exception if different

result $=$ self.stock - other.stock

self.stock $=$ result

return (result)

def calc_progress (self, prev_stock):

"'"' Subtract the current place's stock from its previous value "'"'

result $=$ self.stock - prev_stock

return (result)

def try_giving (self):

"'"' Try to donate material to other place "'""

destination $=-1$

material $=0$

self.aproval = True \# signal there's an amount to transmit

\# print "id \%d: stock \%f, quantum \%f, minimum \%f" \% ।

\# (self.id, self.stock, self.quantum, self.minimum)

if ((self.stock - self.quantum) > self.minimum):

destination = self.mc.go next (self.id)

material $=$ self.quantum

self. aproval $=$ True

return (destination, material, 0)

def do_give (self, aproval):

"'"' Effectuate material donation, if aproved "'"'

self.aproval = aproval \# signalizes nothing to transfer

if (aproval):

self.stock $=$ self.stock - self.quantum

return (aproval) 
def receive (self, quantum):

"'"' Receive material, but add it to a previous buffer "'"'

\# TODO: check if quantum is not negative

was_received $=$ True

received $=$ quantum

total $=$ self.stock + self.pre_buf + received

\# TODO: what about partial receiving ?

\# TODO: what about receiving excess just to transfer it in next iteration ?

if (total > self.maximum):

was received $=$ False

received $=0$

self.pre_buf $=$ self.pre_buf + received

return (received)

def incorporate (self):

\# TODO: check whether amount in pre-buffer exceeds maximum

\# TODO: consider an exception in case it does.

self.stock $=$ self.stock + self.pre_buf

self.pre_buf $=0$ \# to signal nothing to receive anymore

return (True)

def main():

\# TODO: some testing of Sedimentation_place class

print 'Hello world!'

return $(0)$

if (_name_ $==$ '_ main _ '):

sys.exit (main ()) 
ANEXO 4D. Módulo (Markov_chain.py) que representa a matriz de probabilidades de haver trocas sedimentares entre compartimentos do programa.

\#!/usr/bin/env python

import time

import random

class Markov_chain:

"'"'Class for the construction of a Markov chain matrix, with several utilities"'"'

class_name $=$ "Markov_chain"

def__init_ (self, array, seed $=0$ ):

self.state $=-1$

self.array $=[]$

self.n_rows $=$ self.n_cols $=$ len (array)

n_rows $=0$

for ind in range (len (array)):

if (len (array[ind]) != self.n_cols):

$\mathrm{msg}=($ "Row \%d has \%d columns, instead of \%d" \% । (ind, len (array[ind]), self.n_cols))

raise RuntimeError, msg

n_rows $=$ n_rows +1

self.array.append (array[ind])

\# TODO: consist rows

part $=0.0$

for col in range ( len (self.array[ind]) ): part $=$ part + self.array[ind $][\mathrm{col}]$

if (part != 1.0):

msg $=($ "Row \%d should add up to 1.0" \% (ind))

raise RuntimeError, msg

\# if no seed was provided, create one

if $($ seed $==0)$ :

seed $=(1<<21)-1$

self. $r=$ random. Random $($ seed $)$

return

def get_order (self):

\# TODO: exception if n_rows != n_cols

return (self.n_rows)

def calc_class (self, row, absciss):

"'Calculate to which probability class (actually a matrix column) an abscys belongs to, for a given row"'

part $=0.0$ 
\#

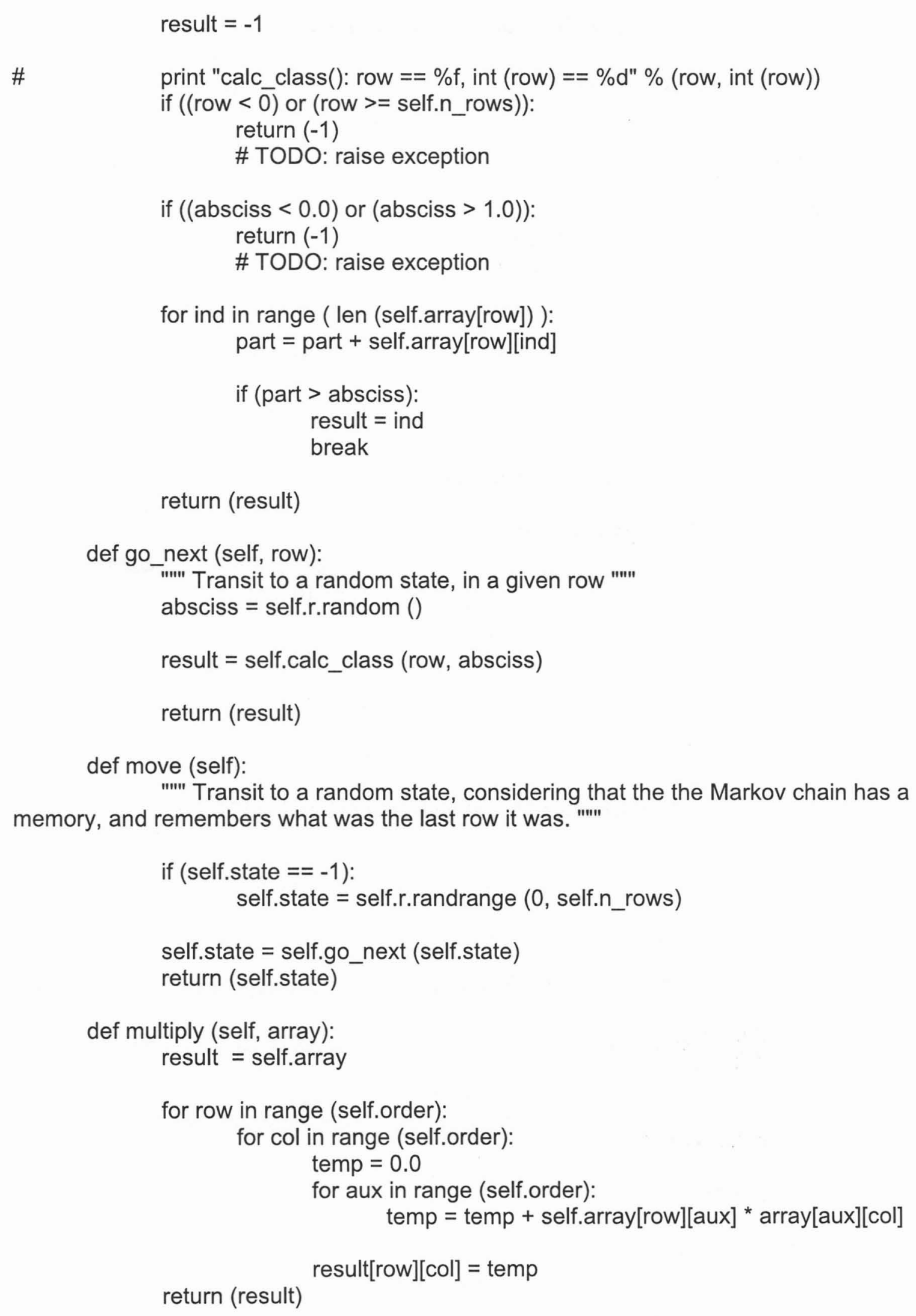

result $=-1$ 
$a=[[0.33,0.33,0.34],[0.34,0.33,0.33],[0.33,0.34,0.33]]$

$m=$ Markov_chain $(a,(1<<21)-1)$

state $=$ m.move ()

print "1st state: \%d" \% (state)

for ind in (range (10)):

state $=$ m.go_next (state)

print "\%d: state \%d" \% (ind, state)

if (__ name $\underset{\operatorname{main}()}{ }=={ }^{\prime} \_$main _ '): 
ANEXO 5. Parâmetros do cenário médio e equações da estrutura do modelo praiaduna (Praia-duna 750 anos.mdl) que promove trocas sedimentares condicionadas a variáveis climáticas, utilizado para simulação de três cenários (úmido, médio e seco).

Initial Time $=0$

Final Time $=365$

Time Step $=0.125$

Unit of Time $=$ Day

Integration Type $=$ Euler

Campo de Dunas $=$ INTEG $($ Fluxo Eolico - Erosao $)\left[\mathrm{m}^{3}\right]$

Praia $=$ INTEG (Entrada Sed Corrente + Erosao - Fluxo Eolico - Saida Sed Corrente) $\left[\mathrm{m}^{3}\right]$

Entrada Sed Corrente $=145\left[\mathrm{~m}^{3} / \mathrm{dia}\right]$

Saída Sed Corrente $=75\left[\mathrm{~m}^{3} / \mathrm{dia}\right]$

Erosão $=25\left[\mathrm{~m}^{3} / \mathrm{dia}\right]$

Fluxo Eólico $=$ IF THEN ELSE (substrato seco=1:AND:transporte vento=1:AND:Praia > volume critico fonte, 275,0$)\left[\mathrm{m}^{3} / \mathrm{dia}\right]$

volume critico fonte $=75000\left[\mathrm{~m}^{3}\right]$

transporte vento $=I F$ THEN ELSE $($ Velocidade vento=1, 1, 0$)$ [adm]

substrato seco $=$ IF THEN ELSE(Chuva $=0$ :AND:Mare $=0,1,0)[\mathrm{adm}]$

Chuva $=\mathrm{IF}$ THEN ELSE (Distribuicao aleatoria da chuva $<400,0,1)[\mathrm{adm}]$

Distribuicao aleatoria da chuva $=$ RANDOM NORMAL(114, 686, 404, Desvio padrao no efeito aleatorio da chuva, Semente para efeito aleatorio da chuva) $\left[\mathrm{mm}^{3}\right]$

Desvio padrao no efeito aleatorio da chuva $=\operatorname{STEP}(141,0)\left[\mathrm{mm}^{3}\right]$

Semente para efeito aleatorio da chuva $=210\left[\mathrm{~mm}^{3}\right]$

Mare $=$ IF THEN ELSE (Distribuicao aleatoria da mare $>0.8,1,0)[\mathrm{m}]$

Distribuicao aleatoria da mare $=$ RANDOM NORMAL(-0.2, 0.9, 0.4, Desvio padrao no efeito aleatorio da mare , Semente para efeito aleatorio de mare) $[\mathrm{m}]$

Desvio padrao no efeito aleatorio da mare $=\operatorname{STEP}(0.2,0)[\mathrm{m}]$

Semente para efeito aleatorio da mare $=2010[\mathrm{~m}]$

Velocidade do vento $=I F$ THEN ELSE (Distribuicao aleatoria do vento $<3.73,0,1)[\mathrm{m} / \mathrm{s}]$

Distribuicao aleatoria do vento $=$ RANDOM NORMAL(0.1, 16, 3.94, Desvio padrao no efeito aleatorio do vento, Semente para efeito aleatorio do vento) $[\mathrm{m} / \mathrm{s}]$

Desvio padrao no efeito aleatorio do vento $=\operatorname{STEP}(3.33,0)[\mathrm{m} / \mathrm{s}]$

Semente para efeito aleatorio do vento $=2010[\mathrm{~m} / \mathrm{s}]$ 